WILLIAN CARREIRA

ANÁLISE DOS DESLOCAMENTOS NO MACIÇO, EM TÚNEL EXECUTADO PELO MÉTODO NATM

São Paulo

2014 
WILLIAN CARREIRA

\section{ANÁLISE DOS DESLOCAMENTOS NO MACIÇO, EM TÚNEL EXECUTADO PELO MÉTODO NATM}

Dissertação apresentada à Escola Politécnica da Universidade de São Paulo, para obtenção do título de Mestre em Ciências.

São Paulo

2014 
WILLIAN CARREIRA

\title{
ANÁLISE DOS DESLOCAMENTOS NO MACIÇO, EM TÚNEL EXECUTADO PELO MÉTODO NATM
}

\author{
Dissertação apresentada à Escola \\ Politécnica da Universidade de São \\ Paulo, para obtenção do título de Mestre \\ em Ciências.
}

Área de Concentração: Engenharia Geotécnica

Orientador: Prof. Dr. Paulo de Mattos Pimenta

São Paulo

2014 
Este exemplar foi revisado e corrigido em relação à versão original, sob responsabilidade única do autor e com a anuência de seu orientador.

São Paulo, 15 de outubro de 2014.

Assinatura do autor

Assinatura do orientador

\section{Catalogação-na-publicação}

\section{Carreira, Willian}

Análise dos deslocamentos no maciço, em túnel executado pelo método NATM / W. Carreira. -- versão corr. -- São Paulo, 2014.

$131 \mathrm{p}$.

Dissertação (Mestrado) - Escola Politécnica da Universidade de São Paulo. Departamento de Engenharia de Estruturas e Geotécnica.

1.Maciço (Deslocamento; Análise) 2.Túneis 3.Método NATM I.Universidade de São Paulo. Escola Politécnica. Departamento de Engenharia de Estruturas e Geotécnica II.t. 


\section{DEDICATÓRIA}

Dedico este trabalho a Deus e a toda minha família. 


\section{AGRADECIMENTOS}

A Deus, que me deu a oportunidade de galgar mais um degrau na vida acadêmica.

Agradeço imensamente a minha família. Aos meus pais, que, com muito esforço, me criaram com amor e dedicação e me forneceram todo o necessário para que eu chegasse até aqui. Aos meus irmãos, sempre companheiros e amigos, que me apoiaram a cada etapa. A minha querida e amada esposa, que, com muita paciência, me apoiou em todo o processo de realização deste trabalho, inclusive lendo e comentando cada página. E, especialmente, a minha querida filha, que nasceu no finalzinho dos trabalhos e me proporcionou muita força de vontade para seguir em frente.

A Maffei Engenharia, que me deu a oportunidade de trabalhar como ATO em diversas obras de vulto nacional, inclusive na obra objeto de estudo deste trabalho. Ao Prof. Dr. Carlos Eduardo Moreira Maffei, que me coorientou extraoficialmente, dando-me ideias valiosíssimas para o direcionamento dos estudos. A Ma. Maria Cecília Guazzelli, que me incentivou e apoiou em todo o processo deste curso.

A Escola Politécnica da USP, onde me graduei, que me forneceu base para a realização deste trabalho. Aos professores da graduação e aos da pós-graduação. Ao Prof. Pedro Wellington G. do Nascimento Teixeira, pelas valiosas opiniões e amizade. Às secretárias da pós-graduação, pelo apoio e comprometimento. E, especialmente, ao meu orientador, Prof. Dr. Paulo de Mattos Pimenta, que aceitou o desafio de me orientar na área de túneis, me fornecendo subsídios importantes para a conclusão dos trabalhos.

Não poderia deixar de mencionar os colegas e amigos que participaram da construção da obra do Lote 1 da Linha 5 do Metrô de São Paulo: Eng. Nelson Pedute Strassacappa (Constran), Eng. Paulo Mota (Construcap), Eng. Iran Benedicto Cassoni Leite (Metrô), Eng. Jelson Antonio Sayeg de Siqueira (Metrô), Geólogo Antonio Norberto Mirandola (Vetec), Eng. Luiz Antonio de Menezes (Constran), Eng. Tiago Eugênio Coneglian de Oliveira (Construcap), Eng. Edson Luiz Moreira Silva (Constran), Geólogo Luis Augusto Moreira (Novatecna) e Eng. José Cleriston (Vetec). 
Deus, obrigado pela vida e por todas as alegrias e sofrimentos que a transformam num espetáculo único! (Augusto Cury) 


\section{Resumo}

O crescente aumento de acidentes em obras subterrâneas, sobretudo em meios urbanos, fez com que aumentasse a preocupação mundial com a segurança destas obras. Portanto, ressalta-se a importância da análise dos deslocamentos no maciço em obras de túneis em solo executados pelo método NATM (New Austrian Tunneling Method), visando à segurança da obra, das estruturas vizinhas a obra e, principalmente, das vidas humanas envolvidas.

A instrumentação geotécnica é apenas uma ferramenta, e não uma solução. Ela não pode ser limitada à locação de vários pontos de medidas em um gráfico. É necessária a especificação de critérios para a análise e avaliação dos resultados e a formulação de procedimentos para a interpretação de dados.

Com isso, a presente dissertação tem como objetivo estudar os deslocamentos do maciço no decorrer da execução de um túnel em solo. Propõem-se analisar os dados do túnel em solo executado pelo método NATM, pertencente à obra do Lote 1 da Linha 5 (Lilás) do Metrô de São Paulo. Esse túnel foi instrumentado na fase de execução da obra e acompanhado tecnicamente pelo autor deste trabalho, junto à equipe da Maffei Engenharia. Ao final deste trabalho, pretende-se tecer comentários sobre a importância de uma adequada análise dos deslocamentos no maciço em obras de túneis em solos executados pelo método NATM.

Palavras-chave: Engenharia Geotécnica, Túnel, NATM, Arco Invertido, ATO (Acompanhamento Técnico de Obra), Instrumentação. 


\begin{abstract}
The increasing growth of accidents in underground works, especially in urban areas, caused a magnification in the worldwide concern about the safety of these works.

Therefore, it must be emphasized the importance of the ground displacements analysis in ground tunnels constructed by the NATM method (New Austrian Tunneling Method), aiming the safety of the work, of neighboring structures and mainly of the human lives involved.

Geotechnical instrumentation is just a tool, and not a solution. It can not be limited to the placement of several measurement points on a graph. A criteria must be specified for the analysis and evaluation of results and for the formulation of procedures for data interpretation.

This thesis objective is to study the ground displacements during the execution of a ground tunnel. It is proposed to analyze the data of the tunnel executed by NATM, belonging to the Lote 1 , Line 5 (purple) of São Paulo subway. This tunnel was instrumented during the execution phase of the construction and technically monitored by the author of this thesis, with Maffei Engenharia team. At the end of this paper it is intended to make comments about the importance of adequate displacements analysis in ground tunnels constructed by NATM method.
\end{abstract}

Keywords: Geotechnical Engineering, Tunnel, NATM, Invert Arch, ATO (Technical Monitoring Work), Instrumentation. 


\section{Sumário}

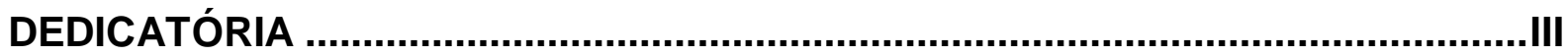

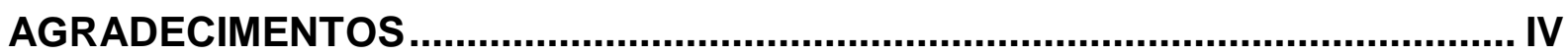

RESUMO

ABSTRACT

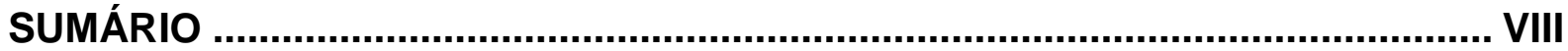

LISTA DE FIGURAS

LISTA DE TABELAS

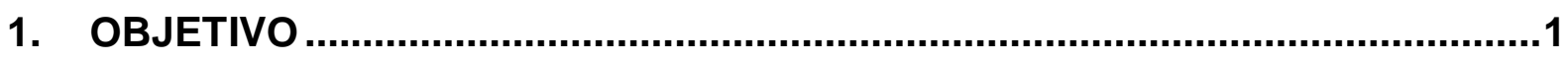

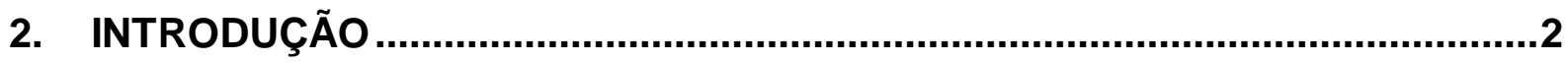

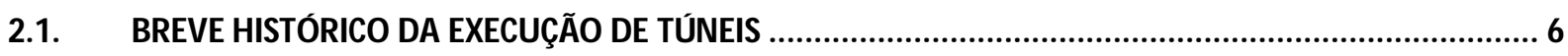

2.2. MÉTODO NATM

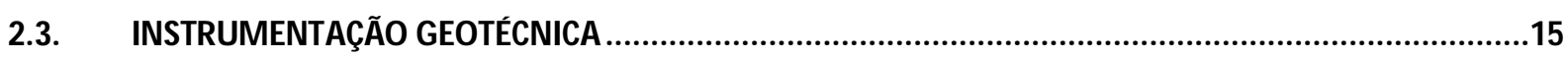

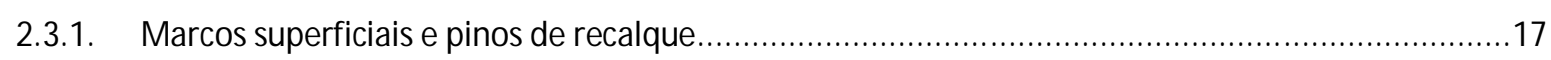

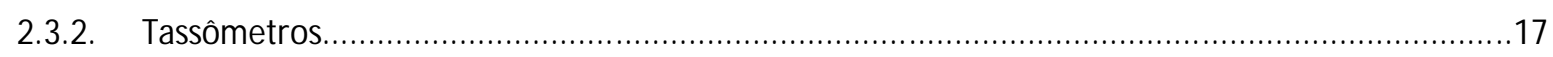

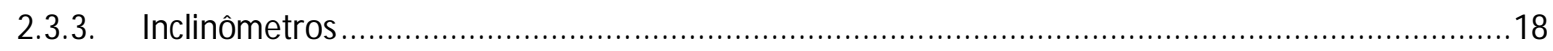

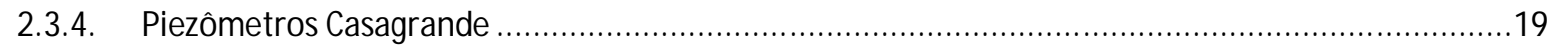

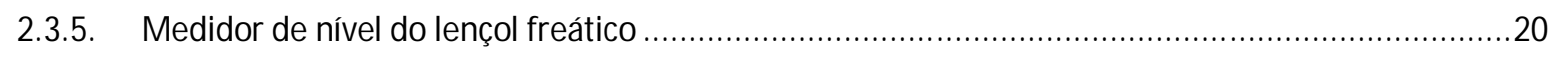

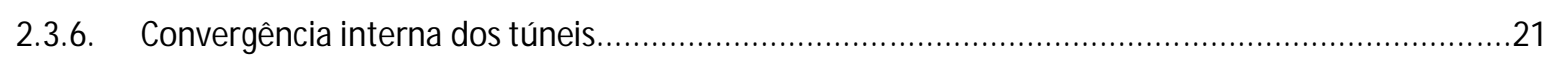

2.3.7. Perfilômetros ou inclinômetros sub-horizontais.........................................................................22

2.4. MECANISM OS DE COLAPSO EM TÚNEIS

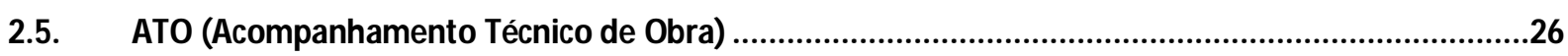




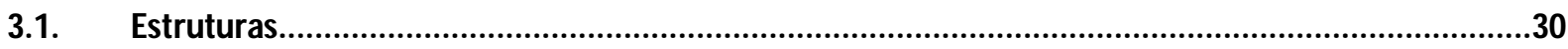

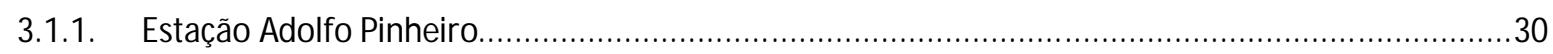

3.1.2. Poço de ventilação e saída de emergência Delmiro Sampaio .........................................................31

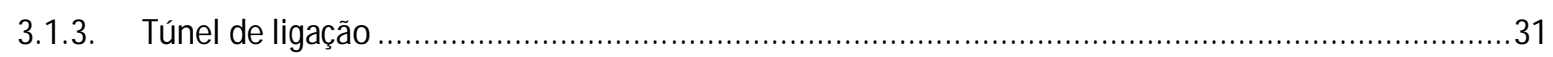

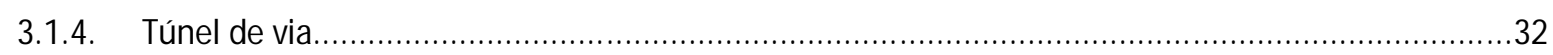

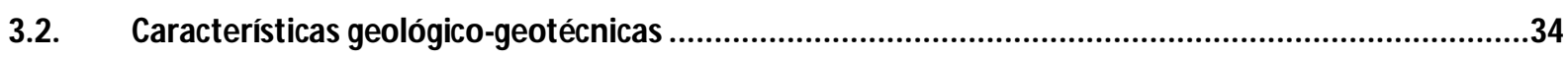

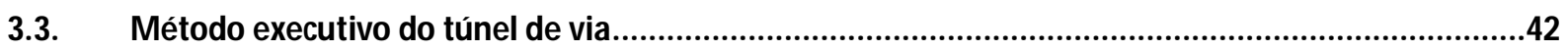

3.4. Sistema de tratamento do maciço (túnel de via)

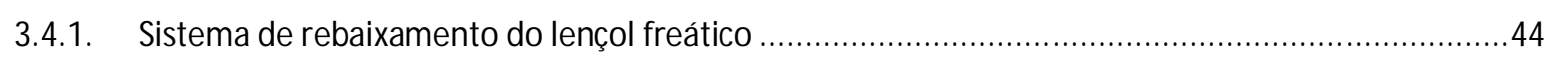

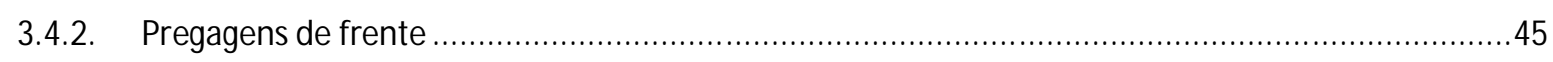

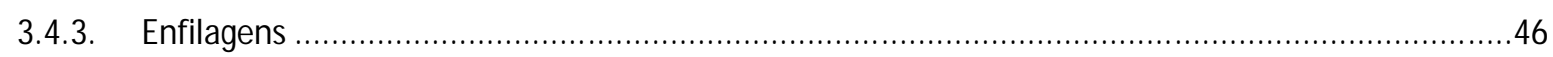

3.5. Instrumentação (túnel de via)

4. ANÁLISE TEÓRICA DA EXECUÇÃO DO SUPORTE ....................................51

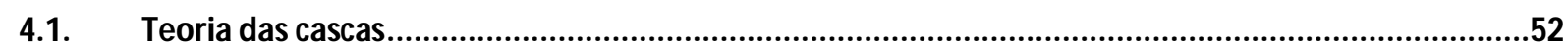

4.2. Arqueamento das tensões do solo

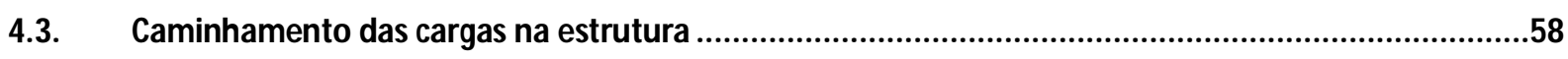

\section{ANÁLISE NUMÉRICA DA EXECUÇÃO DO REVESTIMENTO PRIMÁRIO DO} TÚNEL DO LOTE 1 DA LINHA 5 (LILÁS) DO METRÔ DE SÃO PAULO ...............63

5.1. Software utilizado na modelagem numérica

5.2. MODELO CONSTITUTIVO

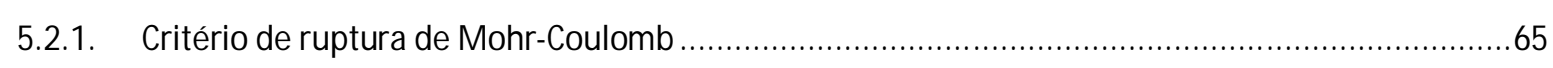

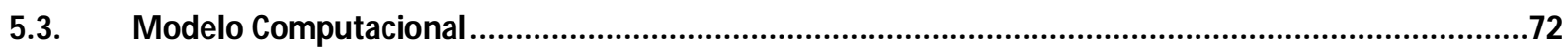

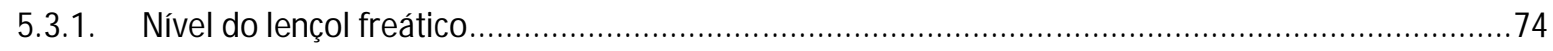

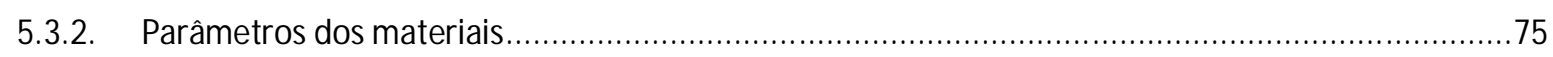

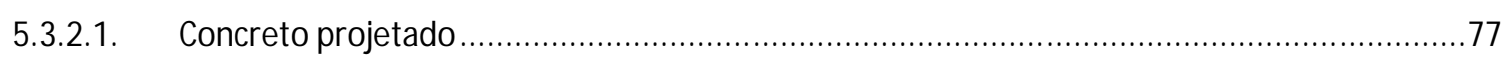

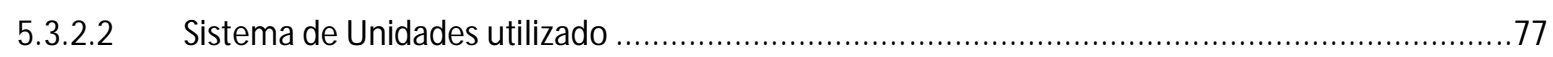

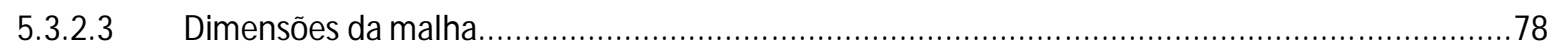




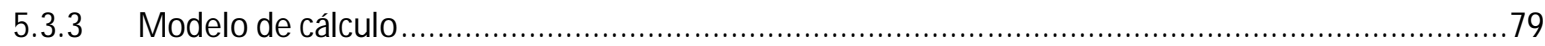

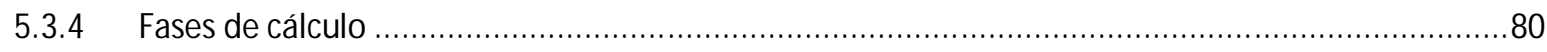

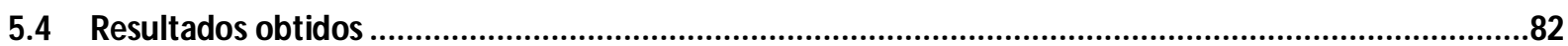

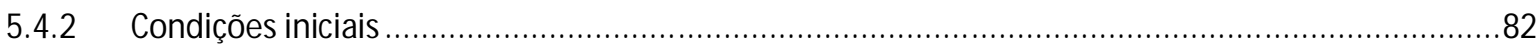

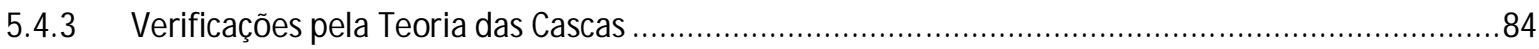

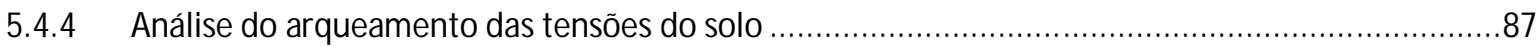

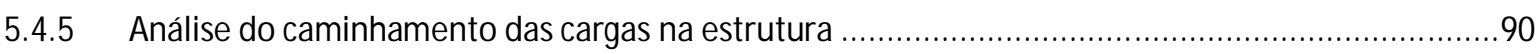

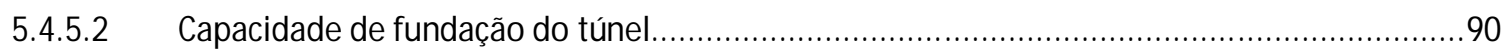

5.4.4.2 Tensões no AIP (Arco Invertido Provisório) ….................................................................92

5.4.4.3 Tensões no AID (Arco Invertido Definitivo) .................................................................94

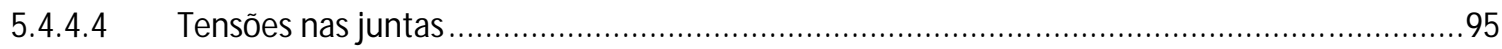

6 COMPARAÇÃO COM OS DADOS OBTIDOS EM CAMPO ............................98

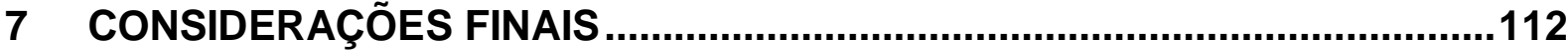

REFERÊNCIAS BIBLIOGRÁFICAS ............................................................116 


\section{Lista de Figuras}

Figura 1 Foto de túnel executado pelo método NATM (Lote 1 - Linha 5 do Metrô SP)......

Figura 2 Croqui com a locação da calota, arco invertido, arco invertido provisório e núcleo frontal

Figura 3 Croqui com a locação do núcleo frontal de solo e defasagem entre a calota e o arco

invertido

Figura 4

Exemplo de junta de concretagem entre o arco invertido e a calota.

Figura 5

Tipo de couraça de madeira (copiado de The Art of Tunneling, Szechy, (04))

Figura 6

Foto da entrada do túnel Holland, Manhattan .....

Figura 7

Visita do Imperador D. Pedro II ao vazamento do Túnel Grande (Silva Telles (06)).......10

Figura 8

Imagem esquemática do túnel utilizado no roubo do Banco Central de Fortaleza .12

Figura 9 Seção típica de instrumentação (copiado de Murakami (10)) .......................................16

Figura 10 Detalhe do marco superficial e pino de recalque (arquivos Maffei Engenharia) ............17

Figura 11 Detalhe do tassômetro (arquivos Maffei Engenharia) .................................................18

Figura 12 Detalhe do inclinômetro (arquivos Maffei Engenharia) ...........................................19

Figura 13 Detalhe do piezômetro tipo Casagrande (arquivos Maffei Engenharia) ........................20

Figura 14 Detalhe do medidor de nível do lençol freático (arquivos Maffei Engenharia) ................21

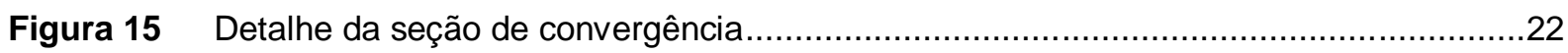

Figura 16 Zonas de influência dos mecanismos global e local (copiado de Murakami (10)) ..........23

Figura 17 Principais tipos de mecanismos locais (copiado de "Instruções de projeto de túnel",

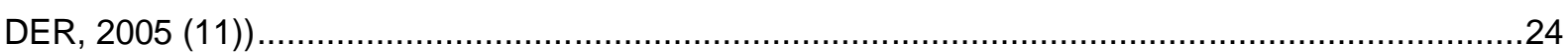

Figura 18 Principais tipos de junta de concretagem entre a calota e o arco invertido ....................25

Figura 19 Locação da obra de expansão da Linha 5 (Lilás) do Metrô SP (PBA - Plano Básico

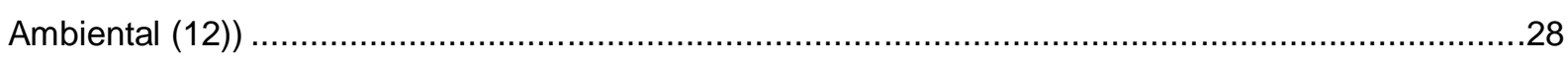

Figura 20 Construção da Estação Adolfo Pinheiro da Linha 5 (Lilás). Hugo Rocha (13)...............29

Figura 21 Planta com a locação da Estação Adolfo Pinheiro da Linha 5 (Lilás)............................30

Figura 22 Poço de ventilação e saída de emergência Delmiro Sampaio .......................................31

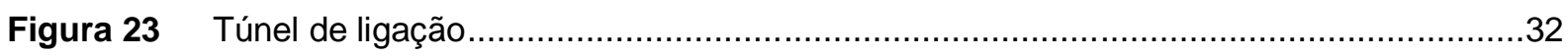

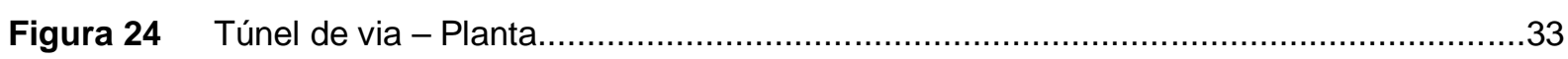

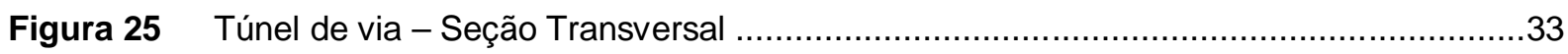

Figura 26 Mapa do Relevo e Geologia do Município de São Paulo (Prefeitura SP (14))................35

Figura 27 Perfil geológico (desenhos obtidos a partir dos perfis de projeto).................................39

Figura 28 Detalhe de instalação dos poços com bombas submersas (PBS's) ..............................45

Figura 29 Seção transversal com a locação das enfilagens e pregagens ...................................47

Figura 30 Seção longitudinal com a locação das enfilagens e pregagens ......................................47

Figura 31 Seção típica de instrumentação do túnel de via - seção Tipo A ....................................49

Figura 32 Seção típica de instrumentação do túnel de via - seção Tipo B .....................................49

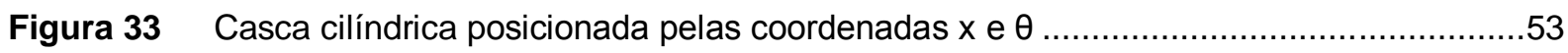

Figura 34 Arqueamento de tensões (copiado de França, 2006 (21)) .........................................55 
Figura 35 Efeito do arqueamento tridimensional (longitudinal e transversal) ….........................56

Figura 36 Efeitos no maciço resultantes da escavação do túnel (copiado de França (20)) ............57

Figura 37 Distribuição das tensões e dos deslocamentos ao longo de uma linha longitudinal situada no teto do túnel (Eisenstein et al. (22)) .....................................................................57

Figura 38 Distribuição das tensões no decorre da execução do arco invertido definitivo................58

Figura 39 Cargas no revestimento na região do núcleo frontal ....................................................59

Figura 40 Tensão no solo sob a base da calota (efeito de punção do solo) ................................60

Figura 41 Cargas no revestimento com a execução do arco invertido .........................................60

Figura 42 Forças na região das juntas entre a calota e o arco invertido (copiado de Dr. Kolymbas

Figura 43 Elementos de um modelo de elementos finitos (Brady \& Brown (27)) ........................64

Figura 44 Definição dos parâmetros de resistência .............................................................66

Figura 45 Superfície de plastificação de Mohr-Coulomb........................................................68

Figura 46 Curvas tensão-deformação do modelo Mohr-Coulomb ...............................................68

Figura 47 Modelo de Mohr-Coulomb com fluxo não associado, incluindo a função de potencial

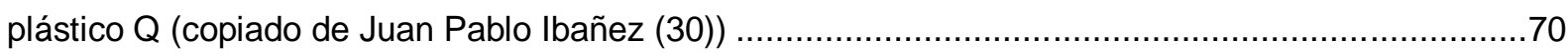

Figura 48 Evolução dos parâmetros c e $\phi$ com a deformação plástica de desvio acumulada

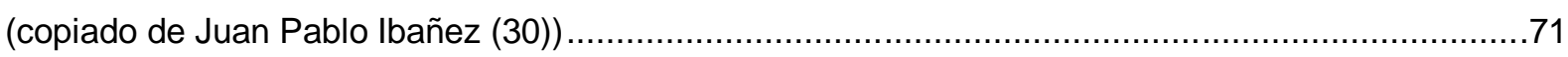

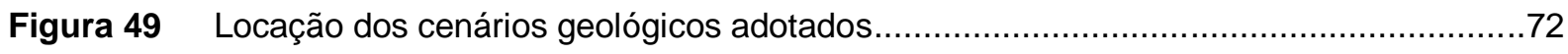

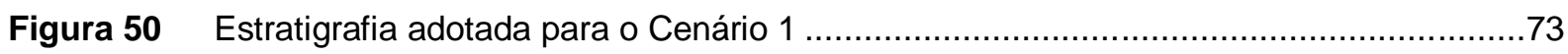

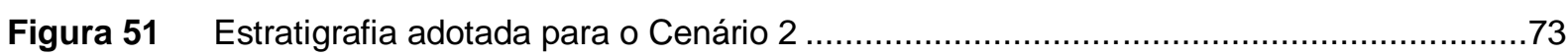

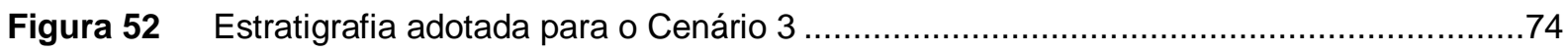

Figura 53 Gráfico dos piezômetros do túnel de via (copiado da Companhia do Metropolitano de

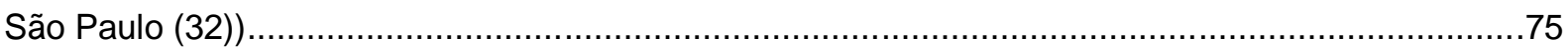

Figura 54 Discretização do modelo geológico-geotécnico em malha de elementos finitos e condições de contorno adotado para o Cenário 1 .

Figura 55 Discretização do modelo geológico-geotécnico em malha de elementos finitos e condições de contorno adotado para o Cenário 2

Figura 56 Discretização do modelo geológico-geotécnico em malha de elementos finitos e condições de contorno adotado para o Cenário 3

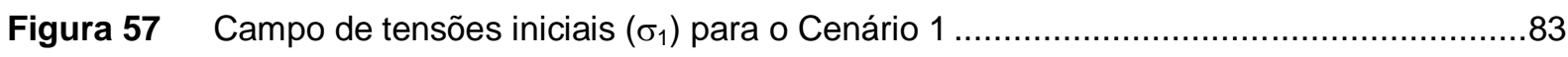

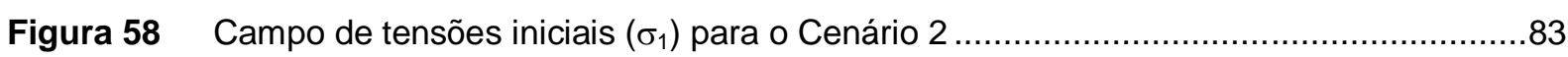

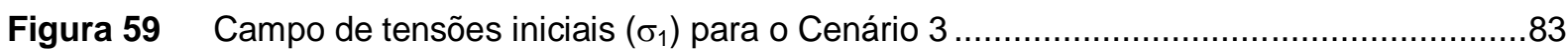

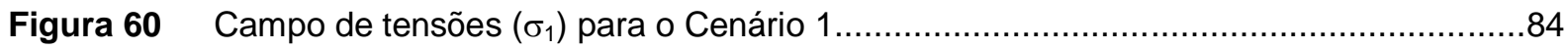

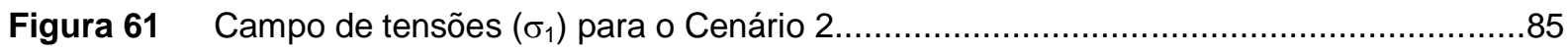

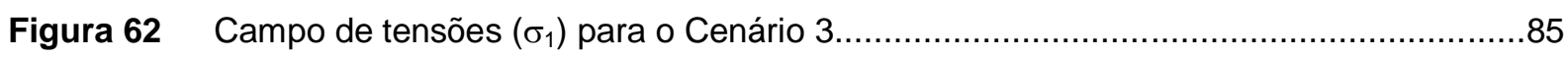

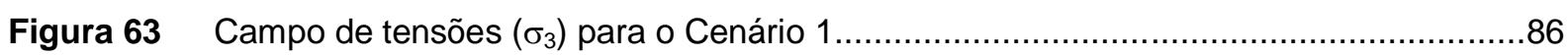

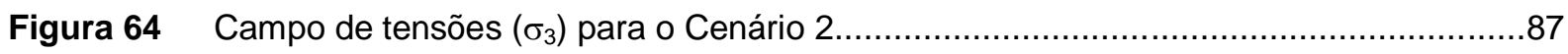

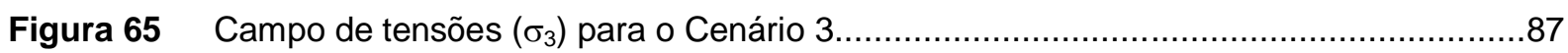


Figura 66 Diagrama de tensões $\left(\sigma_{1}\right)$ com vetores das tensões principais no estado inicial............88

Figura 67 Diagrama de tensões $\left(\sigma_{1}\right)$ com vetores das tensões principais para o Cenário $1 \ldots \ldots \ldots \ldots . . .88$

Figura 68 Diagrama de tensões $\left(\sigma_{1}\right)$ com vetores das tensões principais para o Cenário 2 2...........89

Figura 69 Diagrama de tensões $\left(\sigma_{1}\right)$ com vetores das tensões principais para o Cenário 3...........89

Figura 70 Fatores de capacidade de carga (copiado de Vargas (35)) ......................................90

Figura 71 Diagrama das tensões na fundação da calota, com vetores da reação $(R)$ do solo para o

Cenário 1

Figura 72 Diagrama das tensões na fundação da calota, com vetores da reação $(R)$ do solo para 0

Cenário 2

Figura 73 Diagrama das tensões na fundação da calota, com vetores da reação $(R)$ do solo para o

Cenário 3

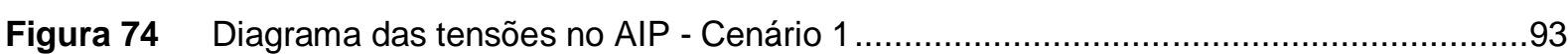

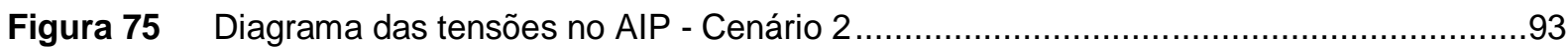

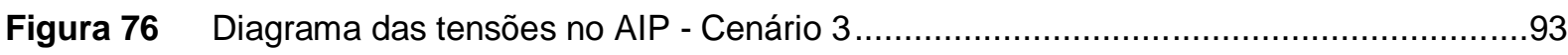

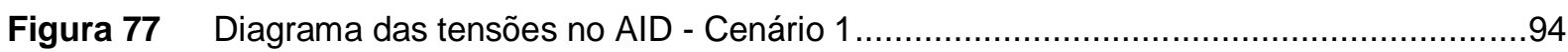

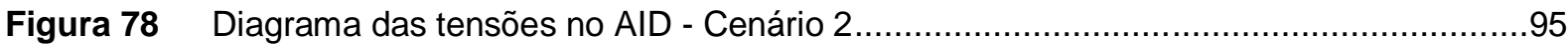

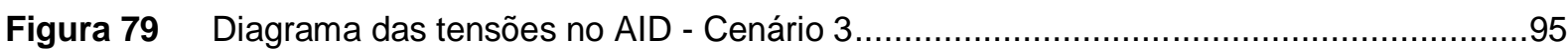

Figura 80 Diagrama de deformação por cisalhamento na junta entre o revestimento do AIP e da calota - Cenário 1

Figura 81 Diagrama de deformação por cisalhamento na junta entre o revestimento do AIP e da calota - Cenário 2 .

Figura 82 Diagrama de deformação por cisalhamento na junta entre o revestimento do AIP e da calota - Cenário 3

Figura 83 Bacia de recalques superficiais - Calota: análise numérica x obra - Cenário 1 .............99

Figura 84 Bacia de recalques superficiais - Calota: análise numérica $x$ obra - Cenário 2 ............99

Figura 85 Bacia de recalques superficiais - Calota: análise numérica $x$ obra - Cenário $3 \ldots \ldots \ldots . . .100$

Figura 86 Bacia de recalques superficiais - AIP: análise numérica x obra - Cenário $1 \ldots \ldots \ldots \ldots \ldots . . .100$

Figura 87 Bacia de recalques superficiais - AIP: análise numérica x obra - Cenário 2 ...............101

Figura 88 Bacia de recalques superficiais - AIP: análise numérica x obra - Cenário 3...............101

Figura 89 Bacia de recalques superficiais - AID: análise numérica x obra - Cenário 1...............102

Figura 90 Bacia de recalques superficiais - AID: análise numérica x obra - Cenário 2 ...............102

Figura 91 Bacia de recalques superficiais - AID: análise numérica x obra - Cenário 3...............103

Figura 92 Deslocamentos no interior do maciço: análise numérica x obra - Cenário 1 .............103

Figura 93 Deslocamentos no interior do maciço: análise numérica x obra - Cenário 2 ...............104

Figura 94 Deslocamentos no interior do maciço: análise numérica x obra - Cenário 3 ...............104

Figura 95 Deslocamentos superficiais em função do tempo: análise numérica $x$ obra - Cenário $1 \ldots$

Figura 96 Deslocamentos superficiais em função do tempo: análise numérica x obra - Cenário 2...

Figura 97 Deslocamentos superficiais em função do tempo: análise numérica x obra - Cenário 3... 
Figura 98 Deslocamentos no interior do maciço em função do tempo: análise numérica x obra -

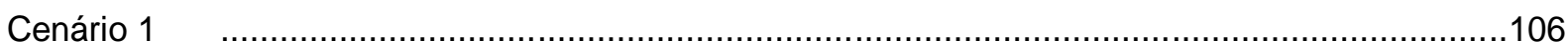

Figura 99 Deslocamentos no interior do maciço em função do tempo: análise numérica x obra -

Cenário 2

Figura 100 Deslocamentos no interior do maciço em função do tempo: análise numérica x obra -

Cenário 3 


\section{Lista de Tabelas}

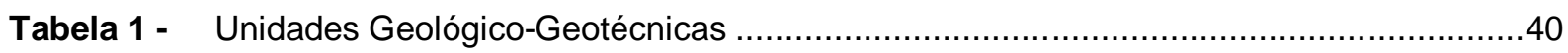

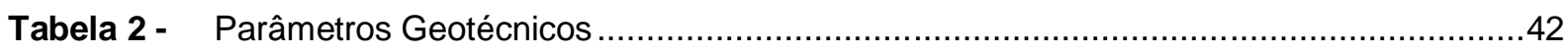

Tabela 3 - Quantidades dos instrumentos utilizados no túnel de via ...........................................50

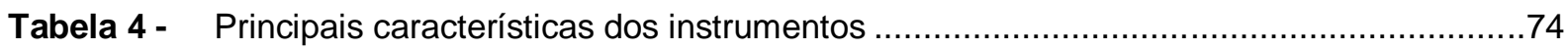

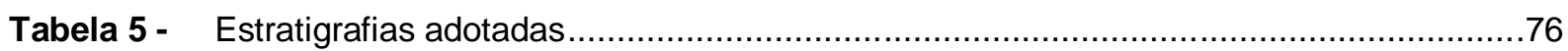

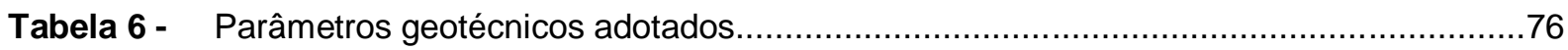

Tabela 7 - Comparação entre o carregamento teórico e o da modelagem numérica.......................85

Tabela 8 - Capacidades de fundação das sapatas e fatores de segurança..................................91 


\section{OBJETIVO}

A presente dissertação tem por objetivo analisar os deslocamentos no maciço no decorrer da execução de um túnel em NATM (New Austrian Tunneling Method). Nas análises, será enfatizada a importância do acompanhamento técnico de obra (ATO) e da instrumentação geotécnica em obra de túneis em solo executados pelo método supracitado, bem como a adequada análise dos resultados obtidos pela instrumentação, visando à segurança da obra, das estruturas vizinhas a obra e, principalmente, das vidas humanas envolvidas.

Outra finalidade deste trabalho é abordar vários aspectos relevantes para uma adequada análise dos deslocamentos no maciço, como: conceitos do método NATM, os principais instrumentos utilizados neste tipo de obra, mecanismos de ruptura em túneis e conceitos sobre o ATO (Acompanhamento Técnico de Obra).

Propõem-se analisar os dados do túnel em solo executado pelo método NATM, pertencente à obra do Lote 1 da Linha 5 (Lilás) do Metrô de São Paulo. Esse túnel foi instrumentado na fase de execução da obra e acompanhado tecnicamente pelo autor deste trabalho, junto à equipe da Maffei Engenharia. As principais características da obra estão detalhadas no capítulo 3 desta dissertação. Ao final deste trabalho, pretende-se tecer comentários sobre a importância de uma adequada análise dos deslocamentos no maciço em obras de túneis em solos executados pelo método NATM. 


\section{INTRODUÇÃO}

O crescente aumento de acidentes em obras subterrâneas, principalmente em meios urbanos, fez com que aumentasse a preocupação mundial com a segurança destas obras. Os túneis executados em NATM (New Austrian Tunneling Method), assim como aqueles executados pelos demais métodos construtivos, requerem 0 desenvolvimento de considerável habilidade e cuidado em sua investigação, planejamento, projeto, construção e instrumentação, para serem implantados com segurança. Uma obra subterrânea, tanto em meio urbano como em meio não urbano, deve ser projetada e construída de forma que seja possível controlar os níveis de segurança e mantê-los em patamares aceitáveis.

O termo NATM é definido comumente pela comunidade técnica como túneis executados por etapas com revestimento em concreto projetado, conforme Figura 1.

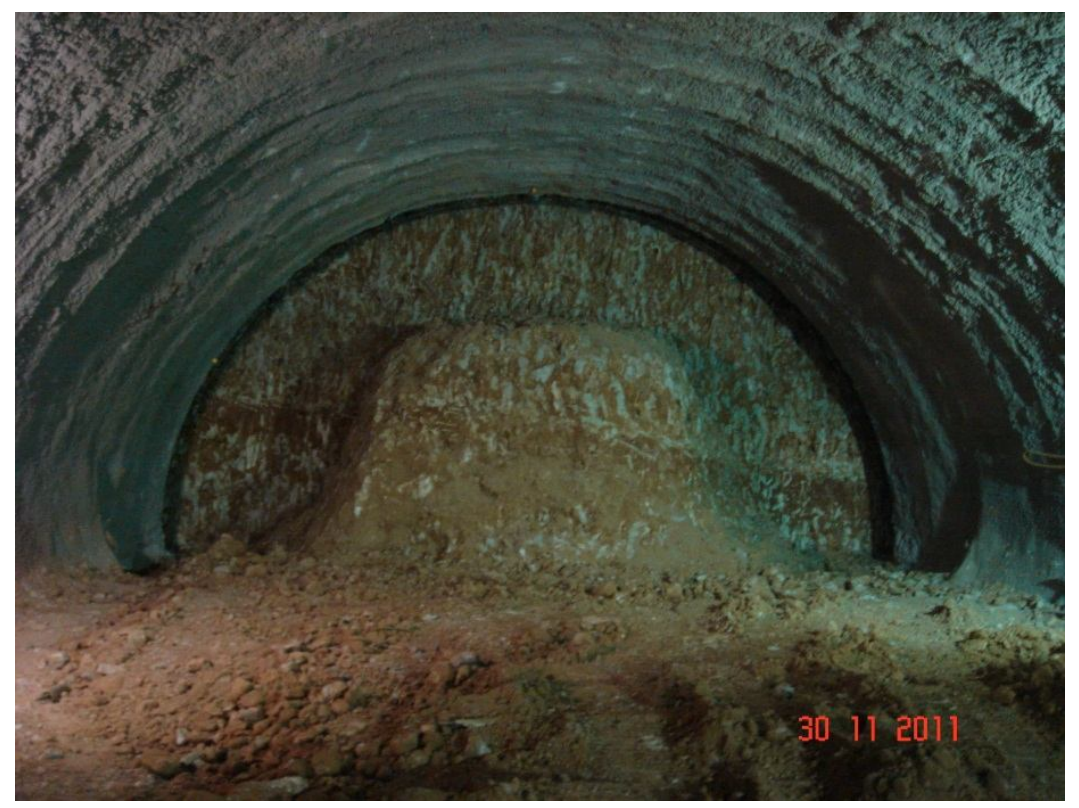

Figura 1 Foto de túnel executado pelo método NATM (Lote 1 - Linha 5 do Metrô SP)

O método NATM é utilizado com sucesso na construção de túneis, poços e estações subterrâneas de grandes dimensões. O método consiste na escavação sequencial do maciço, utilizando concreto projetado como suporte, associado a outros elementos, como cambotas metálicas, pregagens e enfilagens, em função da capacidade autoportante do maciço. Comumente, a sequência de escavação é 
dividida em calota (parte superior) e arco invertido (parte inferior), podendo ou não, adotar o uso de arco invertido provisório, conforme ilustrado na Figura 2. Este último consiste na parcialização da escavação da parte inferior do túnel. A adoção do arco invertido provisório depende da geometria da seção, características e tipo de tratamento do maciço.

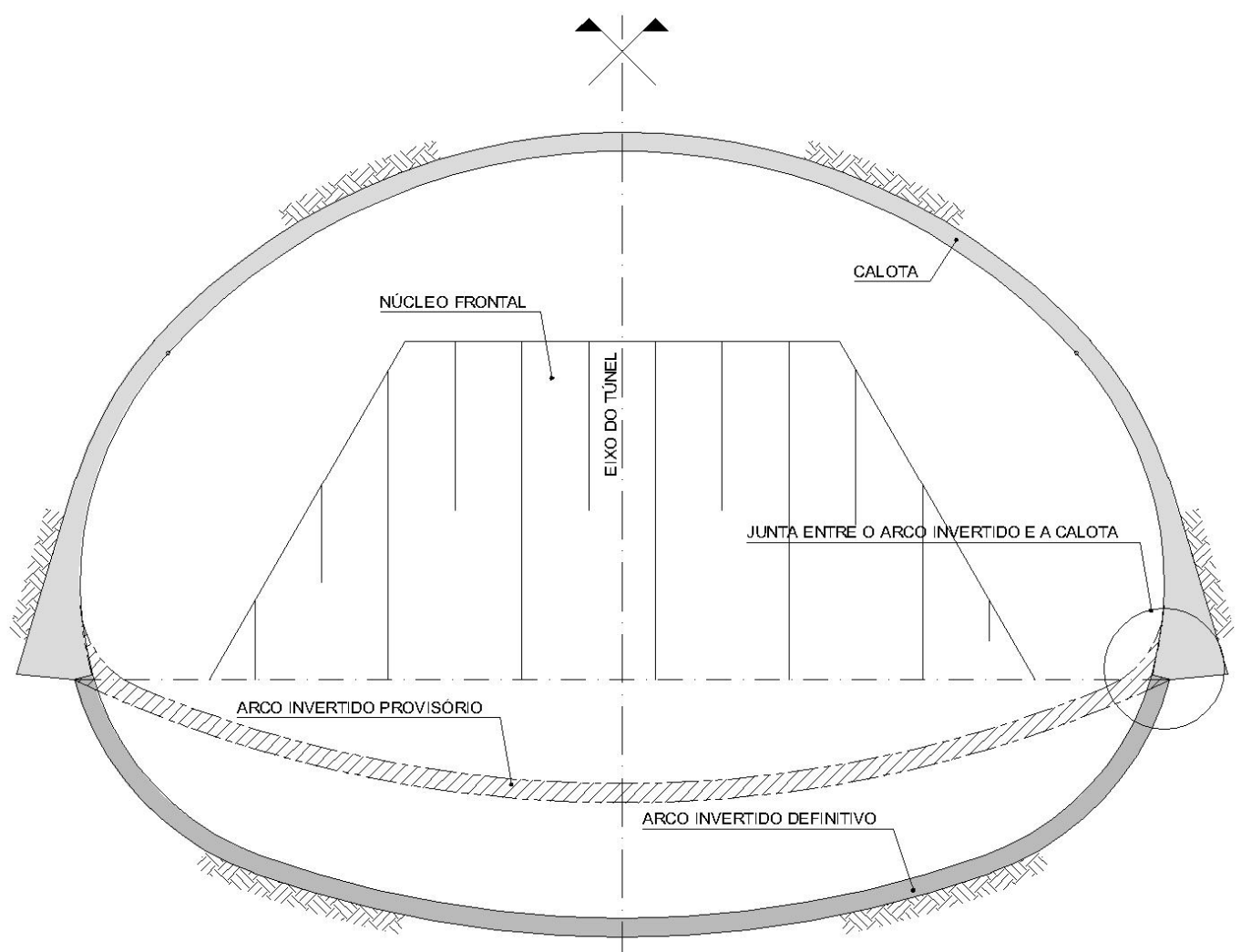

Figura 2 Croqui com a locação da calota, arco invertido, arco invertido provisório e núcleo frontal

A execução do arco invertido, comumente, é defasada em relação à execução da calota, em virtude da adoção de um núcleo frontal, o qual tem a função de estabilizar a frente de escavação. O resultado dessa defasagem é uma junta de concretagem entre as duas estruturas. Essa junta deve ser muito bem projetada e executada, pois tem fundamental importância na distribuição dos esforços internos ao longo do revestimento do túnel e, consequentemente, nas deformações. 


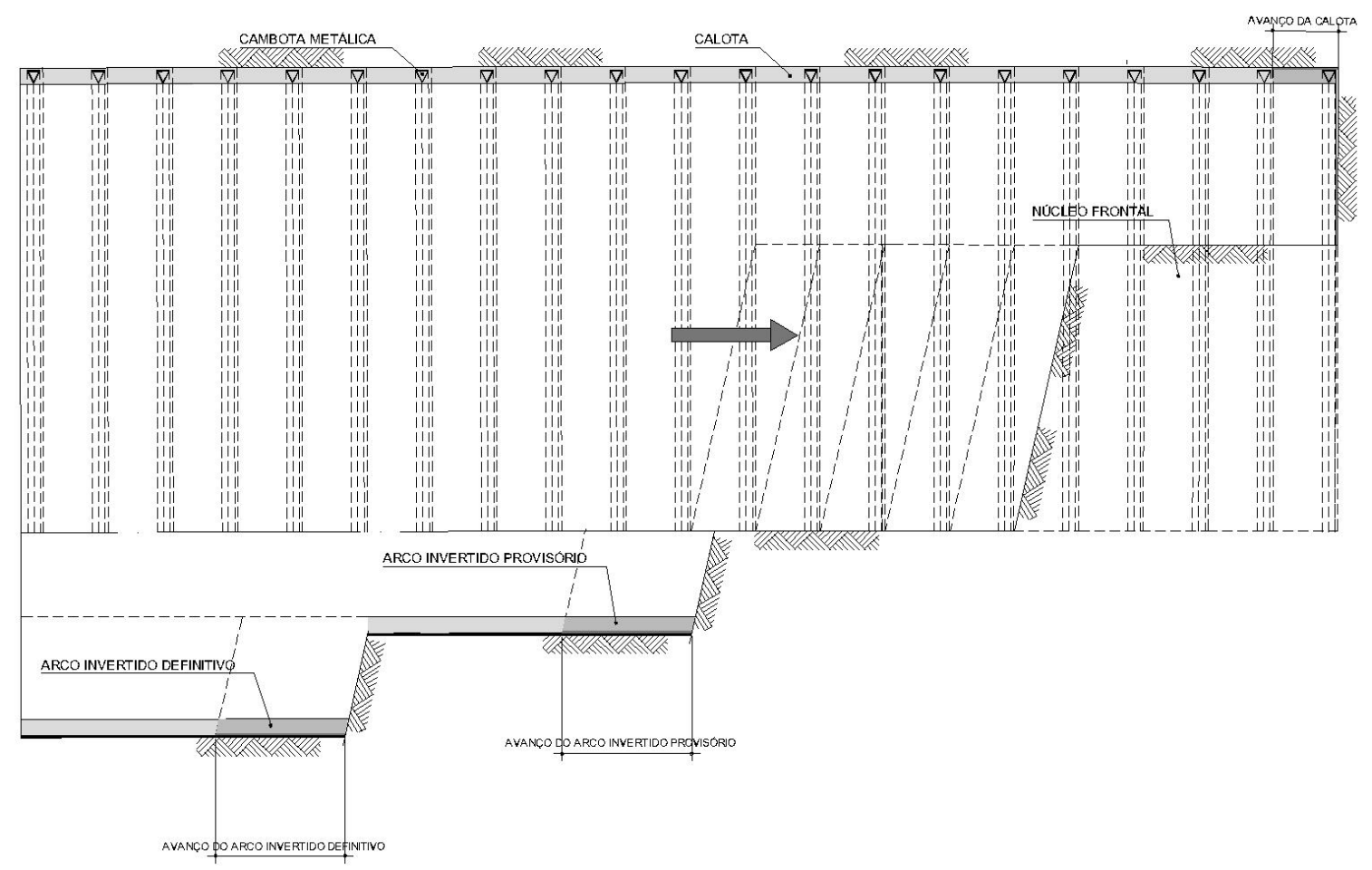

Figura 3 Croqui com a locação do núcleo frontal de solo e defasagem entre a calota e o arco invertido

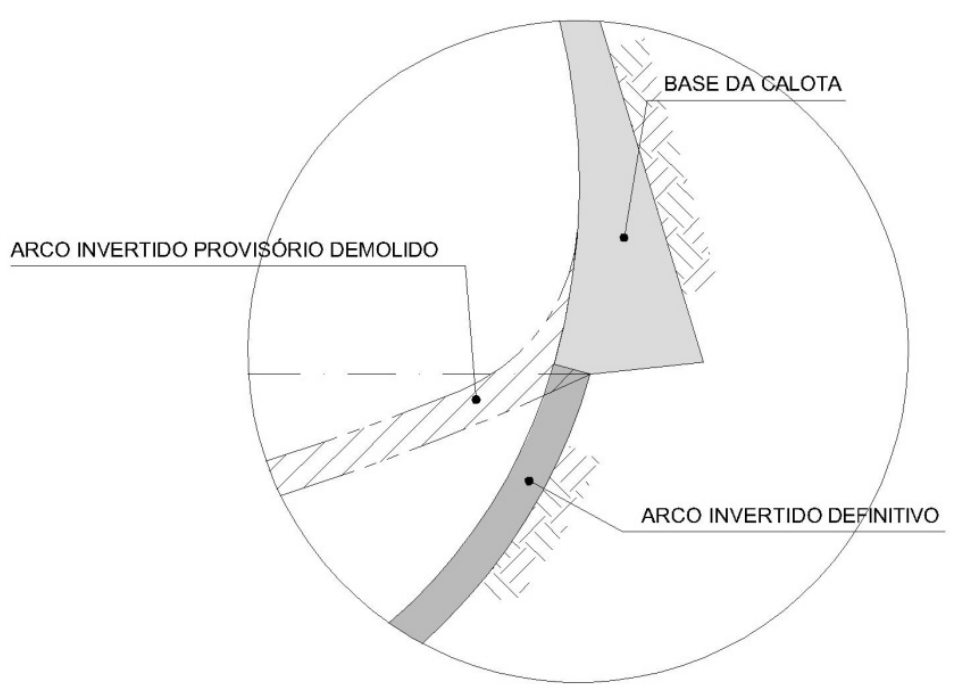

Figura 4 Exemplo de junta de concretagem entre o arco invertido e a calota

Atualmente, a escavação de túneis em regiões densamente ocupadas requer medidas severas para reduzir riscos e possíveis influências em estruturas próximas à obra.

De acordo com Rabcewicz (01), a instrumentação de obras subterrâneas faz parte da própria filosofia do NATM. A aplicação de um revestimento de primeira fase, logo 
após a escavação, tenta restabelecer o equilíbrio pré-existente no maciço e, com isso, faz com que o próprio maciço contribua na sua própria sustentação, exigindo que os deslocamentos decorrentes da interação do maciço com o revestimento sejam acompanhados até sua completa estabilização.

A execução de túneis em solos está associada a uma mudança no estado de tensões no maciço circundante, acarretando movimentações que tendem a se propagar pelo maciço e atingir a superfície causando recalques. Estes, dependendo de sua magnitude, podem causar efeitos indesejáveis a estruturas assentes em suas proximidades.

Portanto, a instrumentação é instalada para conhecer os deslocamentos, deformações e pressões no maciço, além de esforços sobre elementos estruturais, durante a construção. Esse conhecimento tem como finalidade auscultar: cargas, tensões e deformações que confirmem as previsões determinadas em projetos, visto que sempre estão presentes incertezas sobre o comportamento real da obra.

A instrumentação é apenas uma ferramenta, e não uma solução. Ela complementa o acompanhamento da escavação, o mapeamento geológico, a verificação de conformidades e as demais informações de campo. Os objetivos da instrumentação de um túnel são baseados na detecção antecipada das condições que possam motivar a instabilidade do túnel em construção. A análise adequada dessas informações permite, caso necessário, alterar os métodos de escavação, suportes e técnicas de execução, como também realizar uma retroanálise para aferir a qualidade e o nível de segurança real da obra.

O Acompanhamento Técnico de Obra (ATO) é uma atividade importante em qualquer tipo de obra, mas imprescindível em obras subterrâneas, especialmente em túneis. O profissional responsável pelo serviço de ATO deve acompanhar constantemente as condições do maciço no decorrer das escavações e analisar os resultados da instrumentação. Caso haja alguma anormalidade, o mesmo deve tomar as providências cabíveis, juntamente com o projetista, para garantir a segurança da obra. 


\subsection{BREVE HISTÓRICO DA EXECUÇÃO DE TÚNEIS}

José Antônio Juncá Ubierna (03), em seu livro El Túnel. I. Historia y Mito, retrata cuidadosamente a história da construção de túneis desde a antiguidade. Com a finalidade de nortear o leitor deste trabalho em relação ao ambiente histórico no qual ele está inserido, serão apresentados a seguir alguns fatos históricos relevantes, documentados no livro supracitado, entre outras fontes.

$\mathrm{Na}$ Idade Antiga, os homens das cavernas utilizavam cavernas naturais ou escavadas como moradia para se proteger de inimigos perigosos e armazenar alimentos que tinham sidos pescados ou caçados. É possível que o primeiro túnel tenha sido executado pelo homem pré-histórico, que buscava ampliar suas cavernas.

A construção de túneis esteve presente em quase todas as histórias das grandes civilizações, como: Astecas, Incas, Babilônios, Egípcios e Persas.

Com a descoberta do potencial do minério, o homem se viu obrigado a escavar o solo para explorar essa matéria-prima. Na fase primária de mineração, os minerais raros (ouro, pedras preciosas) ficavam expostos na superfície do solo e nos leitos dos rios, e não era tão difícil extraí-los. Com o desenvolvimento, o homem teve que buscar os minérios em fonte mais abundante e rica, o subsolo. Com isso, a tecnologia de escavação de túneis teve que se desenvolver para atender essa demanda.

As minas foram as primeiras obras subterrâneas. As técnicas de escavação subterrânea eram aprimoradas, e surgiu a necessidade de dispositivos para drenagem das minas, para condução da água que abastece os assentamentos urbanos e outras aplicações. A mina mais antiga conhecida, localizada na África, data de 40.000 a.C. e é chamada de Cerro de Bomvu.

Inicialmente, os trabalhadores utilizavam a força bruta para escavação das minas, isso era feito por meio de pedras afiadas, e o material utilizado era o quartzo.

Em 2900 a.C., os egípcios utilizavam uma técnica mais sofisticada para a extração do cobre: faziam furos nos grandes blocos e introduziam cunhas, que eram 
movimentadas ajudando a soltar os materiais; outras vezes introduziam pedaços de madeira, os quais eram encharcados com água, dilatando e fraturando a rocha.

Durante a Idade do Bronze, a rocha dura era fracionada com sistema de fogo. A técnica consistia no aquecimento da rocha com fogo e resfriamento brusco com água.

O principal objetivo da escavação de túneis de minas é a exploração do minério, e é usada temporariamente, para acessar os minerais. O túnel deve manter-se estável no período de extração do minério. Normalmente, os túneis encontrados foram escavados em maciço competente (autoportante). No entanto, em maciços desfavoráveis são encontrados indícios da instalação de suportes rudimentares para evitar o colapso do maciço rochoso.

Portanto, o homem já conseguia avaliar a segurança em função do risco de instabilidade. Assim, improvisava suportes com pedras ou tronco de árvores, embora esse método, do tipo "tentativa e erro", tenha causado muitas mortes, como mostram ossos descobertos por arqueólogos em cavernas que sofreram desmoronamentos. Logo, contar com a colaboração do maciço como parte resistente já era característica da engenharia de túneis da época.

Além dos túneis para mineração, diversas civilizações na Antiguidade construíam túneis para transporte de água, tumbas subterrâneas e templos escavados. $\mathrm{Na}$ Idade Média escavações subterrâneas eram utilizadas pelos cristãos para a construção de igrejas, monastérios, criptas e claustros que compunham os conjuntos religiosos medievais. Em algumas ocasiões, a arquitetura religiosa se conecta com moradias escavadas na rocha.

Há indícios da utilização de pólvora para detonação de rochas na escavação de túneis, em meados do século XVII.

Entre 1820 e 1865, os engenheiros britânicos Marc Brunel e James Greathead idealizaram uma couraça de formato retangular que permitiu a construção de dois túneis em solo sob o rio Tâmisa. Atribui-se também a Brunel o método de "pregagem" para estabilização da frente de túneis. 
A primeira utilização de equipamento hidráulico para perfuração de rocha data de 1857. Quase simultaneamente, Nobel descobriu a dinamite, de modo que na metade do século XIX originou-se o método convencional de execução de túneis em rocha, "drill and blast", o que propiciou o aumento significativo da produção e a simplificação dos métodos construtivos.

Segundo Széchy (04), em seu livro The Art of Tunnelling, a execução de túneis escavados em solo, só foi possível com a utilização de couraças, entre o final do séc. XIX e o séc. XX. Já a execução sem couraça somente foi realizada apenas no início do séc. $X X$.
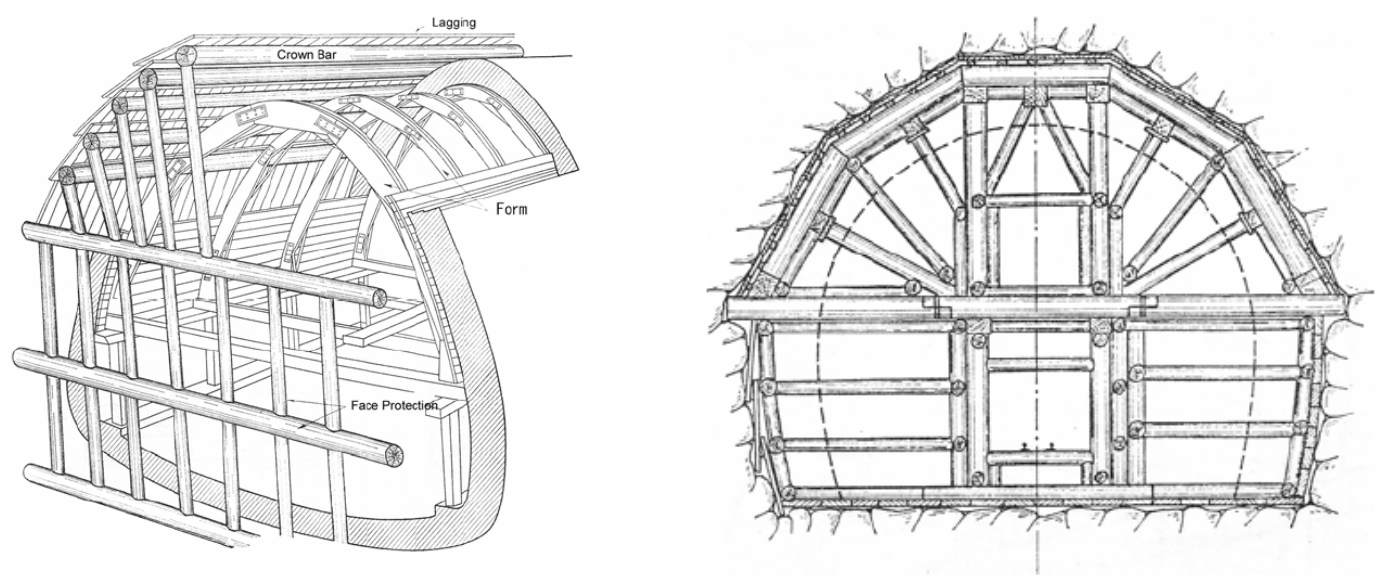

Figura 5 Tipo de couraça de madeira (copiado de The Art of Tunneling, Szechy, (04))

Com a chegada do século $\mathrm{XX}$, trens e carros haviam substituído os canais como as principais formas de transporte, o que levou à necessidade de se construir túneis maiores e mais longos. O túnel Holland, terminado em 1927, foi um dos primeiros túneis feitos para estradas e ainda é um dos mais importantes projetos de engenharia já realizados no mundo, recebendo aproximadamente 100 mil veículos por dia entre Nova York e Nova Jersey (o túnel recebeu o nome do engenheiro que supervisionou a construção). Na sua construção, foi utilizado ar comprimido, para estabilizar a frente de escavação. 


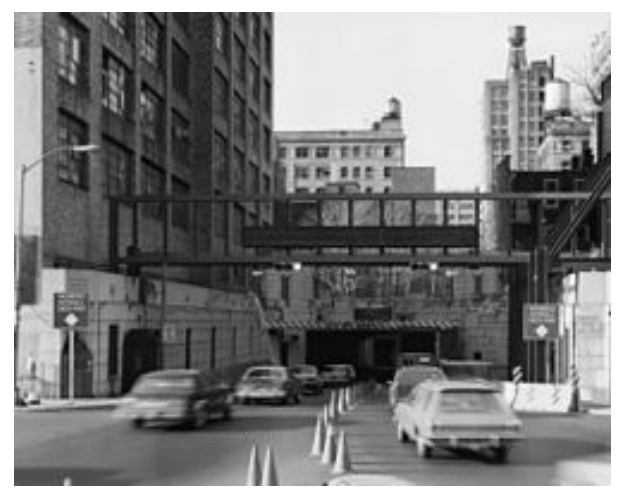

Figura 6 Foto da entrada do túnel Holland, Manhattan

Outra técnica para a estabilização do solo é congelá-lo por meio da circulação de fluido refrigerante por tubulações instaladas em toda a região a ser escavada. Esse método tem sido utilizado desde o ano 1900. Utilizam-se, também, para estabilização do solo, injeções de nata de cimento no solo ou rocha fraturada em torno da escavação do túnel, técnica amplamente utilizada desde os anos 1970.

A história mostra que o desenvolvimento da ciência e da tecnologia é crescente com o tempo, o que vai refletir também no número e dimensões dos túneis, nos materiais, no projeto e nos métodos construtivos.

Enquanto os túneis em minas (túneis mineiros) continuavam sendo executados com suportes de madeira e parcializações de seção, os túneis em solo eram executados com couraça. Na década de 1920 foram executados túneis em solo, com método não destrutivo, ainda utilizando madeira. Porém, no final dessa década, teve início a utilização de perfis metálicos como suporte, em geral com pranchas de madeira entre eles. $O$ revestimento permanente utilizado passou a ser o concreto armado.

Com a ajuda de enfilagens e parcializações da frente de escavação, foi possível construir túneis de grande diâmetro em terrenos inconsistentes. Os revestimentos em chapas metálicas corrugadas ("liner plates") também foram disponibilizados, e, na década de 1940, foram desenvolvidas injeções de cimento.

O desenvolvimento das couraças, de seus revestimentos e dos suportes metálicos potencializou o aparecimento de modelos e métodos de cálculo. No início do século XX, a teoria da Elasticidade e a Teoria da Plasticidade começam a ser utilizadas, a partir de von Mises e Prandtl, de modo que, em 1938, Fenner apresenta o estudo de 
tensões em torno de uma cavidade em rocha, e, em 1939, Mindlin apresenta a solução geral para a determinação analítica das tensões desenvolvidas no entorno da cavidade circular em meio elástico. Kerisel, Terzaghi-Richart (1952) e outros utilizaram as teorias de meio contínuo, variando formas, relações entre tensões geostáticas, resolvendo as equações diferenciais pelos métodos disponíveis na época, de modo que simplificações, às vezes muito restritivas, eram inevitáveis. Paralelamente, os mesmos conceitos deram origem, com as suas especificidades, à Mecânica dos Solos, Mecânica dos Sólidos e Mecânica das Rochas.

Os primeiros túneis ferroviários no Brasil foram abertos por volta de 1860. O trabalho de engenharia mais importante neste período foi a longa série de quinze túneis que ficou conhecida como Seção 2 da Estrada de Ferro Dom Pedro II, no Japeri - Barra do Piraí, linha na Serra do Mar no Estado do Rio de Janeiro. Dom Pedro II era então o Imperador brasileiro. Ele visitava frequentemente as obras de construção. A Figura 7 mostra uma fotografia obtida durante a visita do Imperador, no dia do vazamento do Túnel Grande.

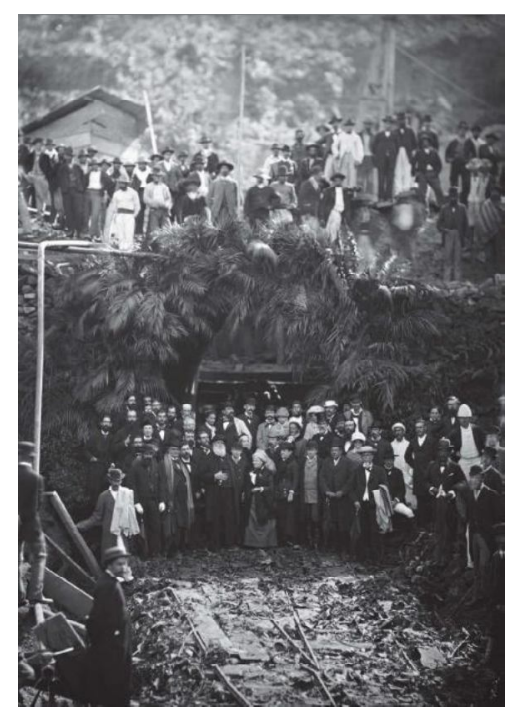

Figura $7 \quad$ Visita do Imperador D. Pedro II ao vazamento do Túnel Grande (Silva Telles (06))

Conforme descrito por Arsênio Negro Jr. et al. (07), no livro Solos da Cidade de São Paulo, o início da execução sistemática de túneis na cidade de São Paulo se deu na década de 1970. Em 1972 foi construído o primeiro túnel metroviário da cidade de São Paulo, parte do trecho Prestes Maia - Luz da Linha Norte-Sul. E, em 1975, a SABESP iniciou a construção do Coletor Tronco Rebouças, o primeiro minitúnel da cidade. 
Inicialmente, a técnica de execução de túneis foi baseada no sistema mineiro, com a utilização de revestimento em aduelas de ferro fundido e chapas de aço corrugado. Na própria década de 1970, iniciaram-se as primeiras tentativas de tratamento do maciço com: rebaixamento do lençol freático, injeções de cimento e o uso de ar comprimido para controle das infiltrações de água.

Em virtude da necessidade de opções para construção de túneis que prescindisse do uso de couraças ("Shields"), em razão do custo elevado desse equipamento, as empresas SABESP e Metrô introduziram o método NATM na cidade de São Paulo na década de 1970. Antes disso, essa técnica já havia sido implantada em túneis viários em áreas não urbanas. O primeiro túnel em NATM na cidade de São Paulo foi o túnel do Alto da Boa Vista - SABESP, em 1978.

O primeiro túnel executado pelo método NATM no Metrô da cidade de São Paulo foi na extensão Norte, em 1982. Essa experiência não foi bem sucedida em virtude de recalques excessivos e ruptura da frente do túnel. Apenas na segunda experiência, em 1984, no túnel duplo da extensão Norte, foi obtido sucesso tanto técnico como econômico.

Atualmente, os túneis são utilizados em diferentes sistemas, como: transporte ferroviário, transporte rodoviário, sistema de água pluvial, esgoto, abastecimento de água, gás, telefonia, entre outros. São conhecidas, também, algumas utilizações de túneis para fins não convencionais, como no caso do túnel executado por presos do complexo do Carandiru, que levaram 30 anos aperfeiçoando planos de resgates subterrâneos, por meio de túneis escavados de fora para dentro, até conseguirem acertar duas fugas, recorde, em apenas sete meses. E o famoso roubo ao Banco Central de Fortaleza, o segundo maior roubo a banco do planeta, segundo SGA Notícia (08), no qual os criminosos escavaram um túnel com 80 metros de extensão e 70 centímetros de largura, de uma casa alugada até o cofre do Banco, como mostra a Figura 8, obtida no site Diálogos Políticos (09), acessado em novembro de 2012. 


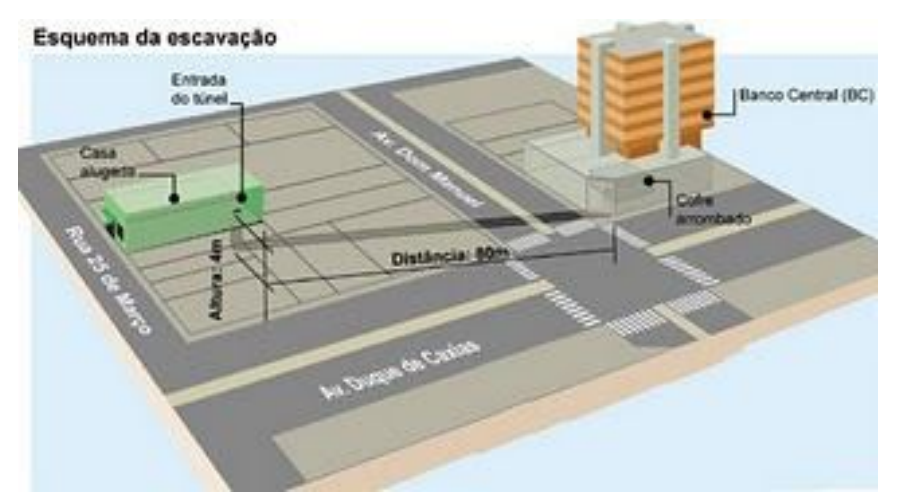

Figura 8 Imagem esquemática do túnel utilizado no roubo do Banco Central de Fortaleza

\subsection{MÉTODO NATM}

Os túneis com revestimento em concreto projetado são normalmente conhecidos como túneis em NATM (New Austrian Tunnelling Method) em virtude do método de escavação de túneis em rocha divulgado por Rabcewicz. Rabcewicz expôs seu pedido de patente na revista Water Power (Parte I e Parte II, 1964, e Parte II, 1965), criando a nomenclatura New Austrian Tunnelling Method (NATM), em contraposição ao Antigo Método Austríaco, utilizado nas minas, e diferenciando-se do que chamava de "American Way of Tunnelling (AWT)".

Conforme descrito pelo Prof. Dr. Techn. L. V. Rabcewicz (01), tendo em vista as deficiências dos métodos de aberturas e revestimentos convencionais, foi proposto um novo método, que consiste em uma camada delgada de concreto projetado, travada no menor tempo possível por meio de um arco invertido, completando o anel, cuja deformação é medida em função do tempo até que o equilíbrio se estabeleça.

Ainda segundo Rabcewicz (01), nos métodos antigos de escavação de túneis, alvenaria de paralelepípedo ou tijolos eram considerados os materiais mais apropriados para o revestimento. Não se utilizava concreto, pois supunha-se que possíveis deformações durante 0 processo de cura poderiam causar danos irreparáveis. Com a introdução de uma camada delgada de concreto projetado como revestimento, executada logo após a escavação, em conjunto com um sistema adequado de tratamento do maciço, evita-se por completo a deformação excessiva do maciço, a ponto de transformar o maciço circundante num arco autossuportante. 
O método NATM foi concebido para túneis em rocha e, posteriormente, adaptado para túneis em solo. Tratando-se de túneis em rocha, a resistência elevada ao cisalhamento pode ser mobilizada com pequenos deslocamentos, mesmo em baixa cobertura, o que cria condições favoráveis para que o maciço participe como elemento resistente. Nos túneis em solo, quanto menor a resistência ao cisalhamento, maior será a necessidade de cobertura para que o maciço colabore na resistência. A baixa resistência e o baixo módulo de rigidez do solo, comparados com a rocha, exigem que os avanços sejam executados em pequenos estágios e com a imediata execução do revestimento primário, para minimizar as deformações.

O NATM caracteriza-se como um método de escavação de túneis que busca o equilíbrio da escavação por meio da instalação progressiva de suportes flexíveis (concreto projetado, cambotas metálicas e chumbadores), com o acompanhamento e controle da evolução das deformações até que estas sejam estabilizadas. Se constatada nos resultados do monitoramento geotécnico e observação da obra alguma tendência de instabilização, executa-se um reforço no revestimento ou tratamentos no maciço. Dessa forma, procura-se otimizar a utilização do suporte e tratamentos por meio do aproveitamento da capacidade de autossustentação do maciço. Uma das hipóteses principais do método, refere-se ao fato de que o maciço não instabilizaria sem aviso prévio. Para tanto, é necessária e obrigatória a implantação de um sistema de instrumentação, para que seja possível avaliar o desempenho do método construtivo, em termos de deformações e de segurança. Essa é a razão pela qual o NATM é conhecido como método das deformações controladas.

Müller e Fecker apud Gehring (1988) (apud Murakami (10)) apresentaram alguns conceitos que devem ser seguidos na execução de túneis para que o NATM seja aplicado com sucesso:

Conceito 1: Através do alívio de tensões, o maciço circundante ao túnel, que inicialmente atua como elemento de carregamento, passa a participar do suporte.

Conceito 2: Preservar a qualidade do maciço circundante, tanto quanto possível, com cuidados durante a escavação e aplicação do suporte, evitando o início de um processo de deterioração do maciço. 
Conceito 3: Impedir a deformação excessiva do maciço, de forma que ela perca a capacidade de autossuporte, passando a constituir um carregamento sobre o suporte.

Conceito 4: Trabalhando-se com deformações compatíveis com o maciço, a capacidade autoportante é conservada. Este passa a trabalhar como um elemento portante.

Conceito 5: Caracterizar geológica e geotecnicamente o maciço, a fim de se obter o máximo subsídio na definição do melhor método construtivo, e também, para o dimensionamento do sistema de suporte e do revestimento.

Conceito 6: Adequar a parcialização da frente de escavação em função do comportamento do maciço, do tempo de autossustentação, da deformabilidade do material e dos equipamentos disponíveis.

Conceito 7: Utilizar o suporte adequado em termos de resistência e deformabilidade no momento certo, tirando partido da capacidade de autossuporte do maciço.

Conceito 8: Não devem ser deixados espaços vazios entre o suporte e o maciço que permitam o desagregamento do material e consequente perda da capacidade de autossuporte.

Conceito 9: Utilizar-se de elementos de suporte (concreto projetado, telas, ancoragens e cambotas) necessários e suficientes para impor tensões confinantes que equilibrem a abertura, mantendo as deformações em níveis aceitáveis.

Conceito 10: Manter o fechamento do invert em distâncias compatíveis com a capacidade de carga da calota aberta e o mais próximo possível da frente de escavação.

Conceito 11: Definir uma seção de escavação com a menor área possível.

Conceito 12: Conceber formas que privilegiem o equilíbrio dos carregamentos predominantemente por esforços de compressão, ou seja, procurar formas arredondadas. 
Conceito 13: Realizar o acompanhamento das deformações por meio de instrumentação, cujas leituras servirão para subsidiar as revisões e otimizações do processo construtivo e do projeto, além de permitir o monitoramento da segurança da obra.

Conceito 14: O acompanhamento das instrumentações deve indicar a total estabilização dos deslocamentos após a conclusão do suporte e do revestimento.

Conceito 15: Drenar o maciço sempre que a presença de água possa provocar algum dano ou mecanismo que ponha em risco a obra.

Atualmente, há uma tentativa, por parte da ITA (International Tunnelling and Underground Space Association), de introduzir uma nova nomenclatura - "Método Convencional" - para túneis escavados em processos cíclicos com execução de revestimento. Esse conceito é bastante subjetivo e não é amplamente utilizado no meio técnico brasileiro atual.

\subsection{INSTRUMENTAÇÃO GEOTÉCNICA}

Monitoramento tem uma longa tradição na engenharia geotécnica. As razões para monitorar, avaliar e interpretar os dados adquiridos são múltiplas: verificação de parâmetros de projeto, controle de qualidade, avaliação da eficácia do método construtivo etc. Estas podem ser as motivações para a implementação de um sistema de monitoramento.

O conhecimento inevitavelmente limitado da configuração geológica e características do solo na fase de projeto, bem como as simplificações utilizadas nas ferramentas de simulação disponível, nos levam, em geral, a um projeto impreciso de estruturas subterrâneas. Como o comportamento do solo pode variar numa vasta gama, suas reais características dificilmente são conhecidas com exatidão antes da execução da obra. Um adequado programa de monitoramento das deformações pode ser usado para melhorar o modelo de solo fora da área visível. Isso permite reagir às mudanças das condições do solo evitando "surpresas" durante a escavação, que são geralmente dispendiosas e demoradas.

Este é o método chamado de observacional, é o mesmo método chamado de 
experimental por Terzaghi, em que o projeto é revisado se as constatações de obra mostrarem que as hipóteses adotadas no projeto levaram a uma concepção contra a segurança da estrutura.

A instrumentação não pode ser limitada à locação de vários pontos de medidas em um gráfico. É necessária a especificação de critérios para a análise e avaliação dos resultados e a formulação de procedimentos para a interpretação de dados.

Segundo Maffei (05), na interpretação da instrumentação, atualmente, existe um conceito em que a estabilização dos deslocamentos indica que a obra é segura. A estabilização se dá para as condições existentes, e não potenciais, e os coeficientes de segurança foram criados para levar em conta acréscimos eventuais de solicitação e minorações eventuais de resistências ao longo da vida útil da obra. Outro conceito que merece ser estudado corresponde ao modo como são definidos os níveis de alerta, de referência e esperado. O valor de referência ou de alerta fornecido pelo projeto é entendido pela equipe da obra como valor determinístico obtido pelos cálculos e, assim, supõe-se que antes dele ser atingido não há problemas de instabilidade na obra. Os níveis de alerta devem ser determinados de modo racional para cada tipo de mecanismo de colapso que possa ocorrer. Do mesmo modo, a análise dos resultados do monitoramento deve estar baseada em mecanismos de ruptura factíveis.

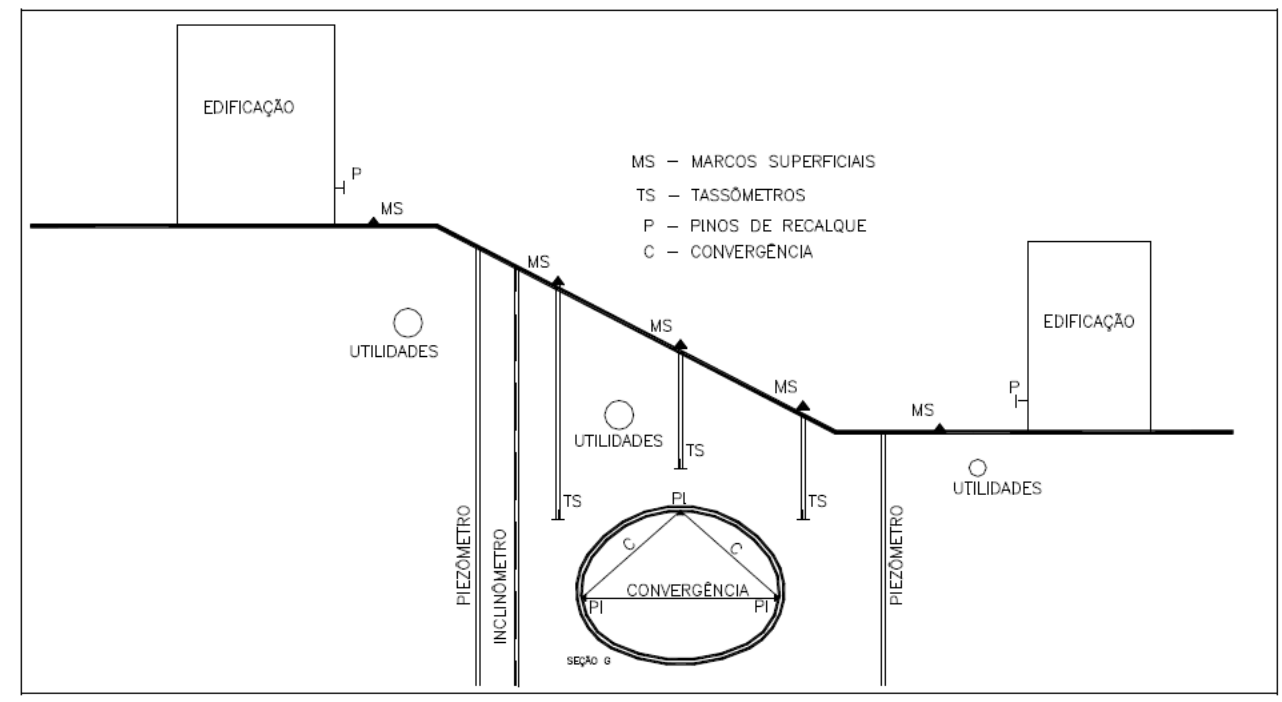

Figura 9 Seção típica de instrumentação (copiado de Murakami (10)) 
A seguir, apresenta-se uma breve descrição dos principais instrumentos utilizados no monitoramento de túneis.

\subsubsection{Marcos superficiais e pinos de recalque}

Os marcos superficiais e pinos de recalque têm a finalidade de medir os deslocamentos verticais na superfície do maciço de terra e em estruturas. Os instrumentos são normalmente constituídos de marcos topográficos instalados na superfície do terreno ou estruturas, cujos deslocamentos são medidos por meio da topografia (níveis de precisão ou estação total), tomando por referência pontos fixos instalados em locais considerados indeslocáveis, fora da área de influência da obra.

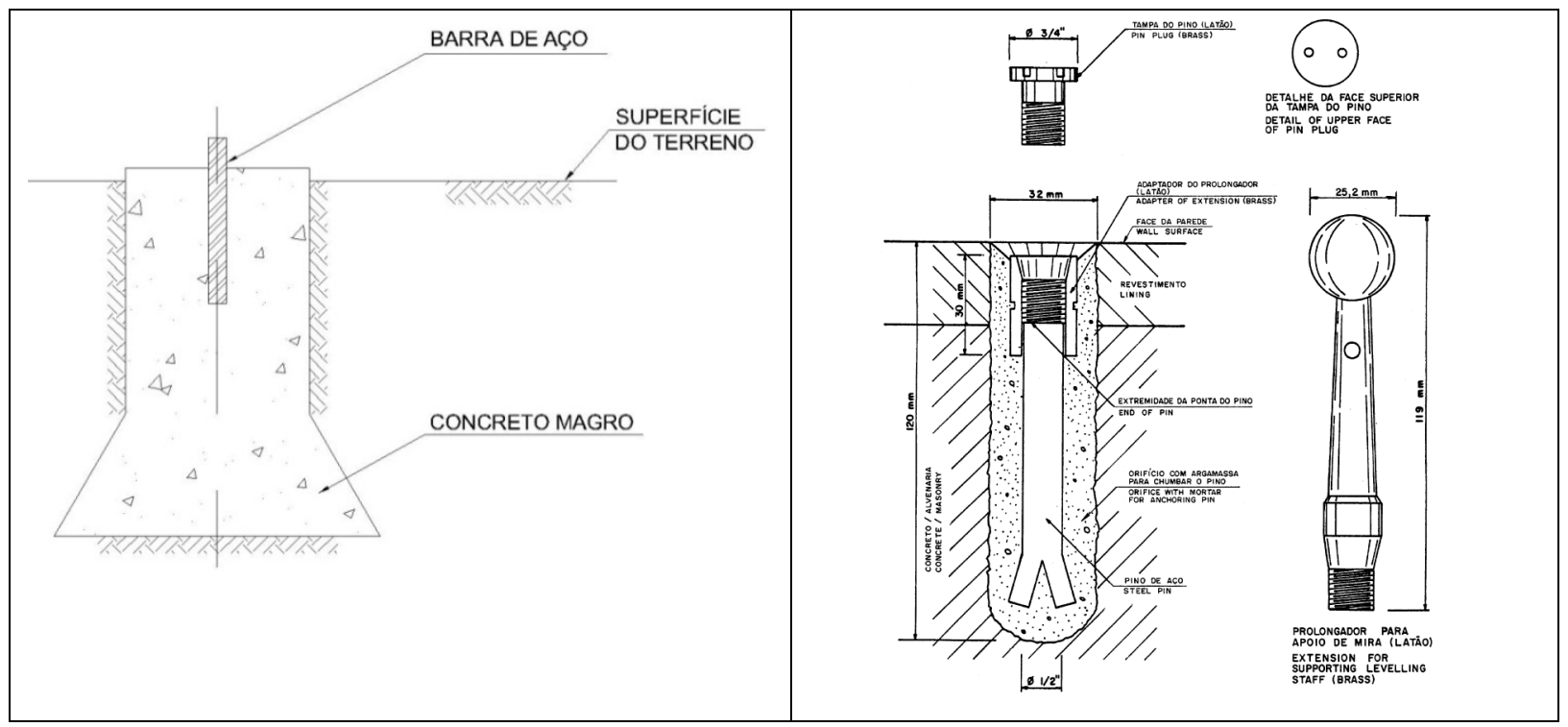

Figura 10 Detalhe do marco superficial e pino de recalque (arquivos Maffei Engenharia)

2.3.2. Tassômetros

Os tassômetros têm a finalidade de medir os deslocamentos verticais no interior do maciço. O instrumento é constituído de uma haste de aço galvanizado, inserida em um furo de sondagem, cuja extremidade inferior é chumbada no ponto de interesse; 
o restante da haste deve ficar livre para não interferir no resultado da medida. Os deslocamentos são medidos por meio da topografia (níveis de precisão ou estação total), tomando por referência pontos fixos instalados em locais considerados indeslocáveis, fora da área de influência da obra.

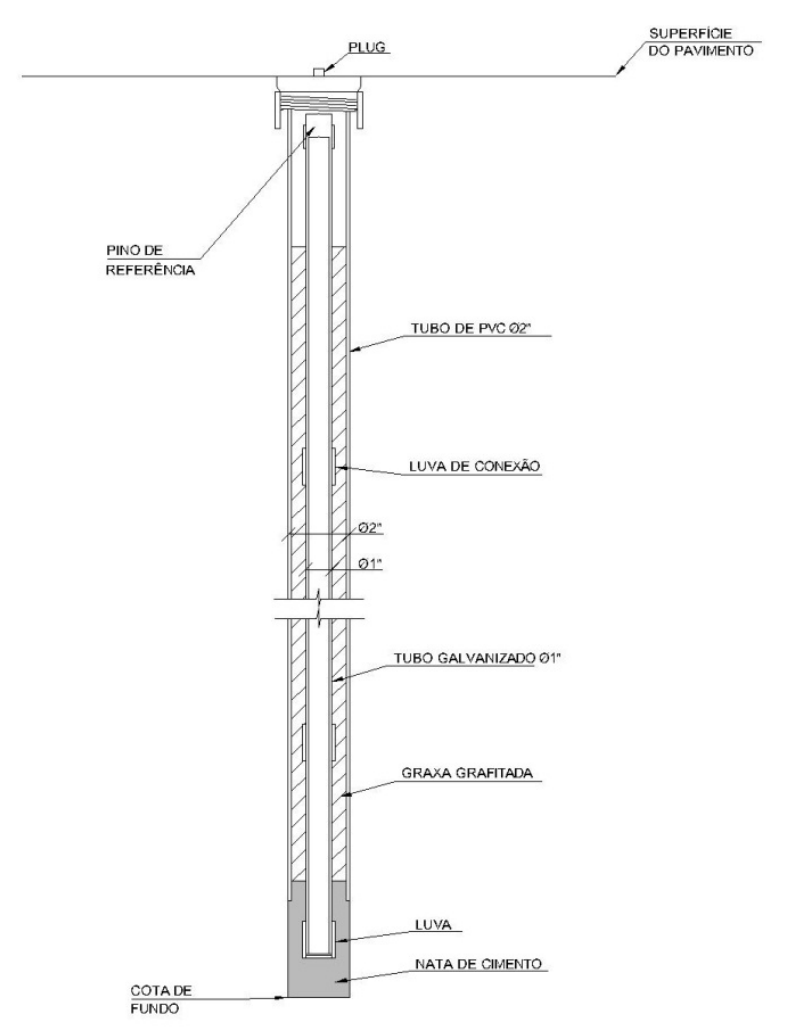

Figura 11 Detalhe do tassômetro (arquivos Maffei Engenharia)

\subsubsection{Inclinômetros}

Os inclinômetros têm a finalidade de medir os deslocamentos horizontais do maciço. O instrumento é constituído de um conjunto de tubos de alumínio ou PVC que possuem quatro ranhuras, duas a duas, diametralmente opostas. A leitura da inclinação é feita por um torpedo introduzido no tubo guia. 


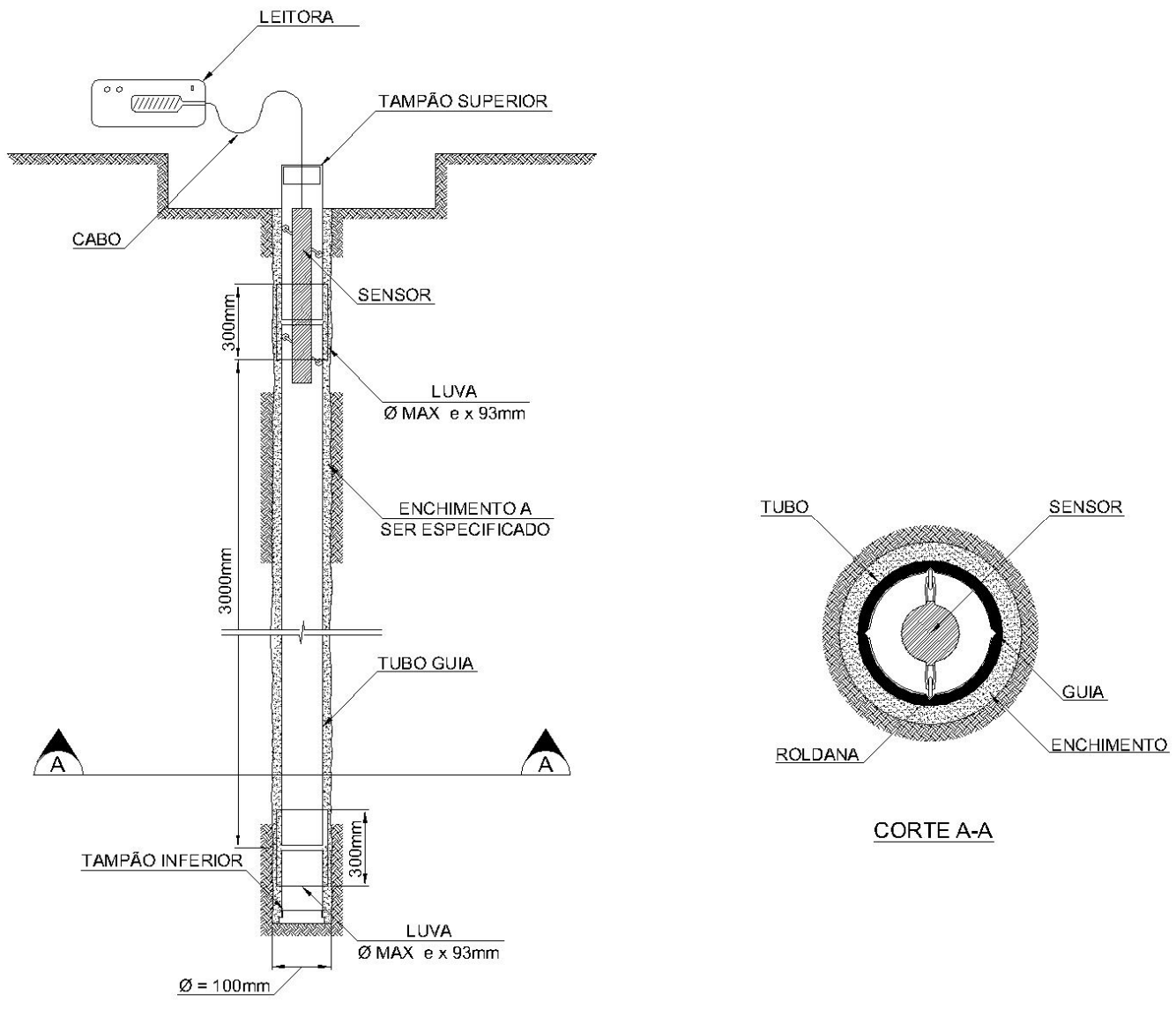

Figura 12 Detalhe do inclinômetro (arquivos Maffei Engenharia)

\subsubsection{Piezômetros Casagrande}

O piezômetro Casagrande tem a finalidade de medir a pressão neutra no maciço em uma determinada região. $\mathrm{O}$ instrumento normalmente é constituído de um tubo de PVC, com um elemento poroso na extremidade inferior (bulbo), inserido em um furo de sondagem. A água penetra através do bulbo, formando uma coluna d'água equivalente à pressão hidrostática atuante no seu ponto de instalação. Na região do bulbo, o furo é preenchido com areia, e, na altura restante, é selado com solocimento plástico ou bentonita, delimitando assim a região drenante. 


\section{Figura 13 Detalhe do piezômetro tipo Casagrande (arquivos Maffei Engenharia)}

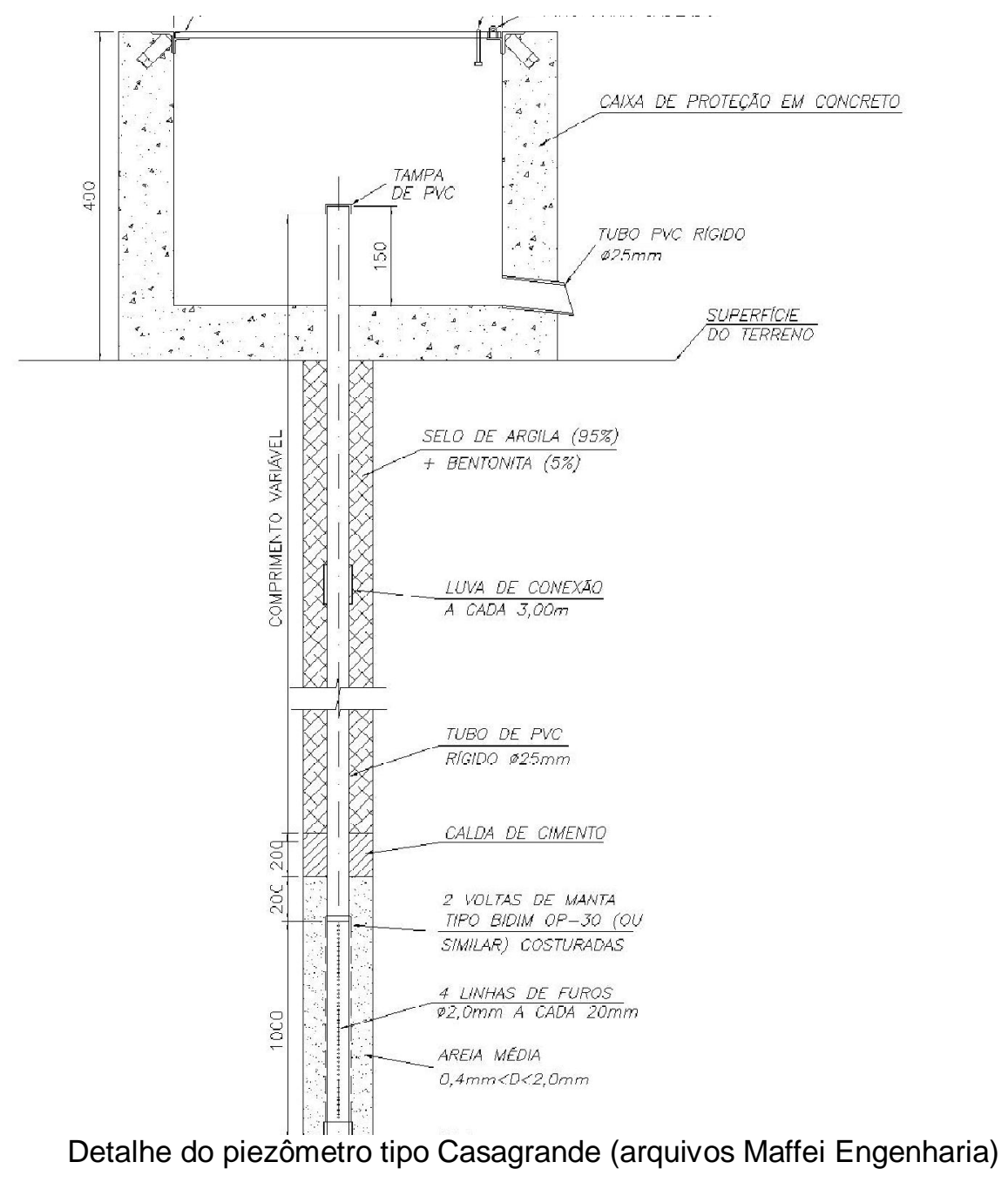

2.3.5. Medidor de nível do lençol freático

O medidor de nível do lençol freático, como o próprio nome relata, tem a finalidade de medir a posição da linha freática no maciço. $O$ instrumento normalmente é constituído de um tubo de PVC perfurado, introduzido num furo de sondagem feito no maciço. $O$ tubo perfurado é envolto por manta geotêxtil ou tela, e inserido no furo, cujo espaço anelar é preenchido com areia para evitar o carreamento de solo. Acima do trecho perfurado é feito um selo de solo-cimento para impedir a entrada de água superficial e/ou pluvial. 


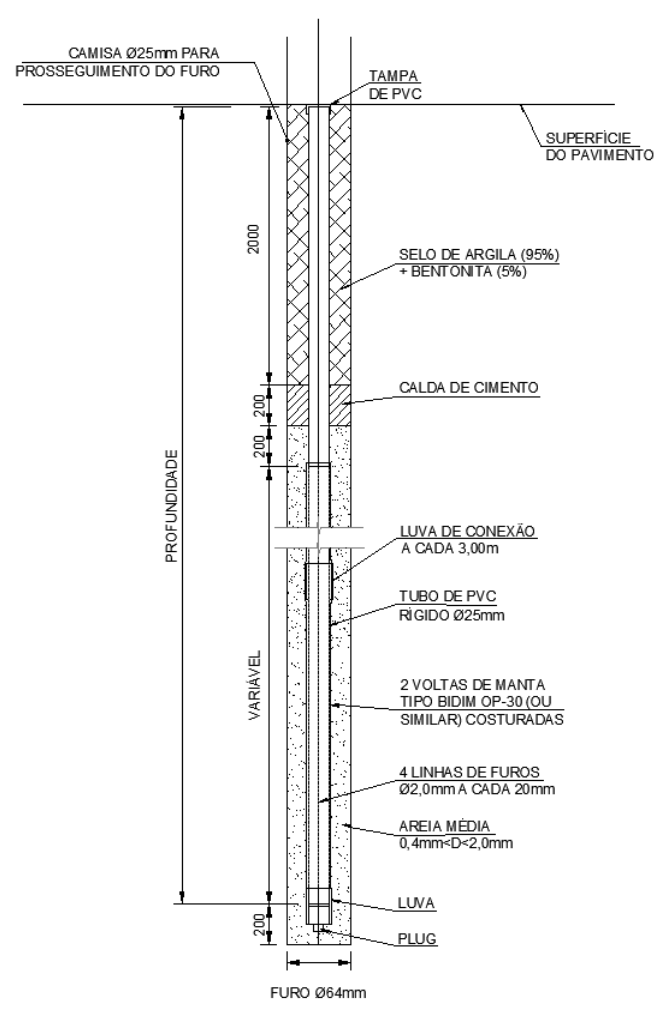

Figura 14 Detalhe do medidor de nível do lençol freático (arquivos Maffei Engenharia)

2.3.6. Convergência interna dos túneis

A convergência interna dos túneis é um instrumento utilizado para medir deslocamento relativo entre dois pontos constituídos de pinos previamente instalados, conhecidos como cordas.

A sistemática geralmente adotada para medição e registro dos dados referentes a variação do comprimento das cordas internas de uma escavação subterrânea (usualmente em NATM) e recalques dos pontos definidos por sua extremidade. Esta medição é comumente conhecida como medida da convergência / divergência e nivelamento interno e está associada à instalação de Pinos de Convergência e Nivelamento.

O processo tem por finalidade monitorar o comportamento de uma escavação subterrânea, durante a construção ou não, detectando a variação das medidas acima mencionadas. Tais medidas fazem parte de um conjunto de dados utilizados para verificar os critérios de projetos e permitir adotar procedimentos de construção 
que levem à implantação da obra com segurança.

São utilizados aparelhos de medição apropriados às magnitudes dos deslocamentos previstos. Todos devidamente aferidos e calibrados. As leituras de convergência podem ser obtidas com um sistema tensionador, dinamômetro, um defletômetro e uma trena de aço ou kevlar e o nivelamento com o nível ótico N3 ou com aparelhos de leitura a base de raio infravermelho.

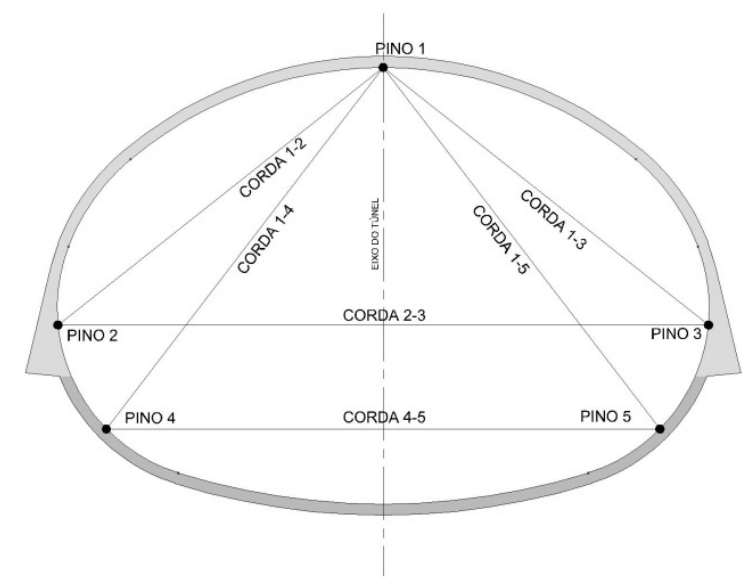

Figura 15 Detalhe da seção de convergência

\subsubsection{Perfilômetros ou inclinômetros sub-horizontais}

Os perfilômetros ou inclinômetros sub-horizontais tem como finalidade medir os deslocamentos verticais ao longo de uma sub-horizontal no interior do maciço.

Estes instrumentos permitem conhecer a evolução dos recalques verticais ao longo da escavação de forma contínua.

O equipamento é instalado em uma perfuração sub-horizontal. A perfuração deve ser realizada com diâmetro adequado, no interior da qual é instalado um tubo flexível. As leituras podem ser realizadas através de sensores instalados ao longo do tubo flexível ou por um torpedo introduzido até o final da perfuração, e a sua posição é medida em relação à boca do furo. 


\subsection{MECANISMOS DE COLAPSO EM TÚNEIS}

Murakami (10), em sua dissertação de mestrado compilou um interessante relato sobre os mecanismos de colapso em túneis. Informações relevantes para a compreensão do presente trabalho são mostradas abaixo.

Os mecanismos de colapso em túneis formam-se pela alteração do estado de tensões no maciço, causados pela escavação ou pelas condições do lençol freático. Tais mecanismos ocorrem, na maior parte das vezes, na frente de avanço do túnel. Uma vez executado o revestimento, os mecanismos no maciço podem ocorrer somente se a estrutura entrar em colapso.

Os mecanismos de colapso em túneis podem ser classificados em locais ou globais, dependendo da magnitude dos seus efeitos, conforme ilustrado na Figura 16.

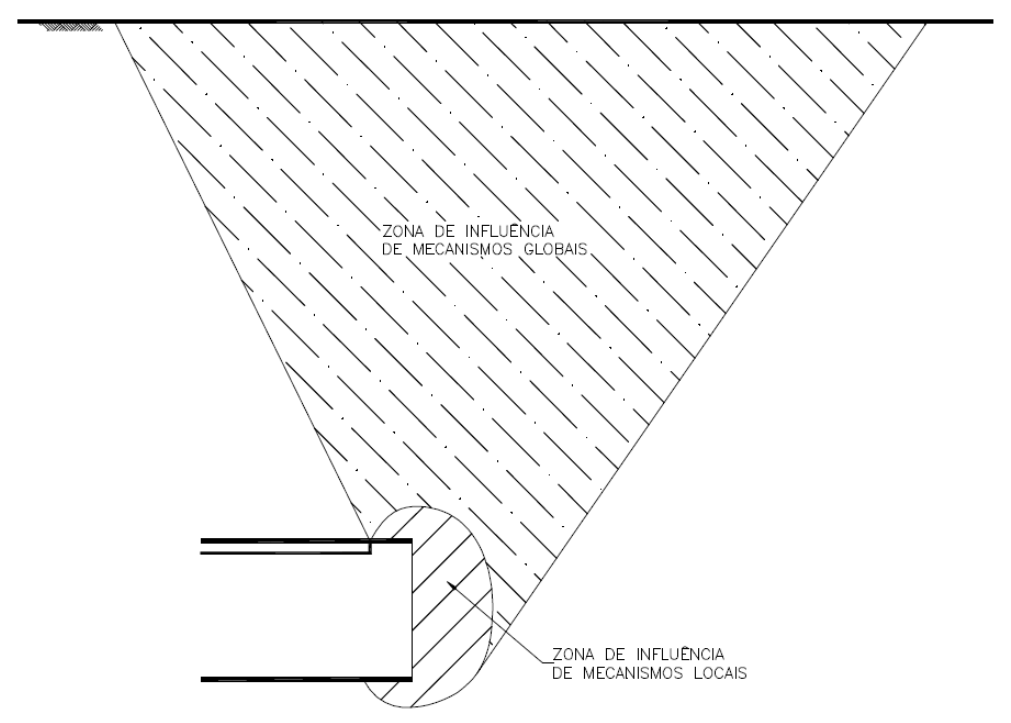

Figura 16 Zonas de influência dos mecanismos global e local (copiado de Murakami (10))

Mecanismos globais são aqueles em que os estados de tensões de volumes do maciço, que se localizam muito além de uma superfície envoltória nas proximidades da escavação, influenciam o equilíbrio do mecanismo. Já os mecanismos locais, são aqueles em que a estabilidade depende apenas das tensões do maciço nas proximidades da frente de escavação. Caso não haja uma intervenção adequada, um mecanismo local pode evoluir e se tornar um mecanismo global. Na Figura 17 apresentam-se os principais mecanismos locais. 

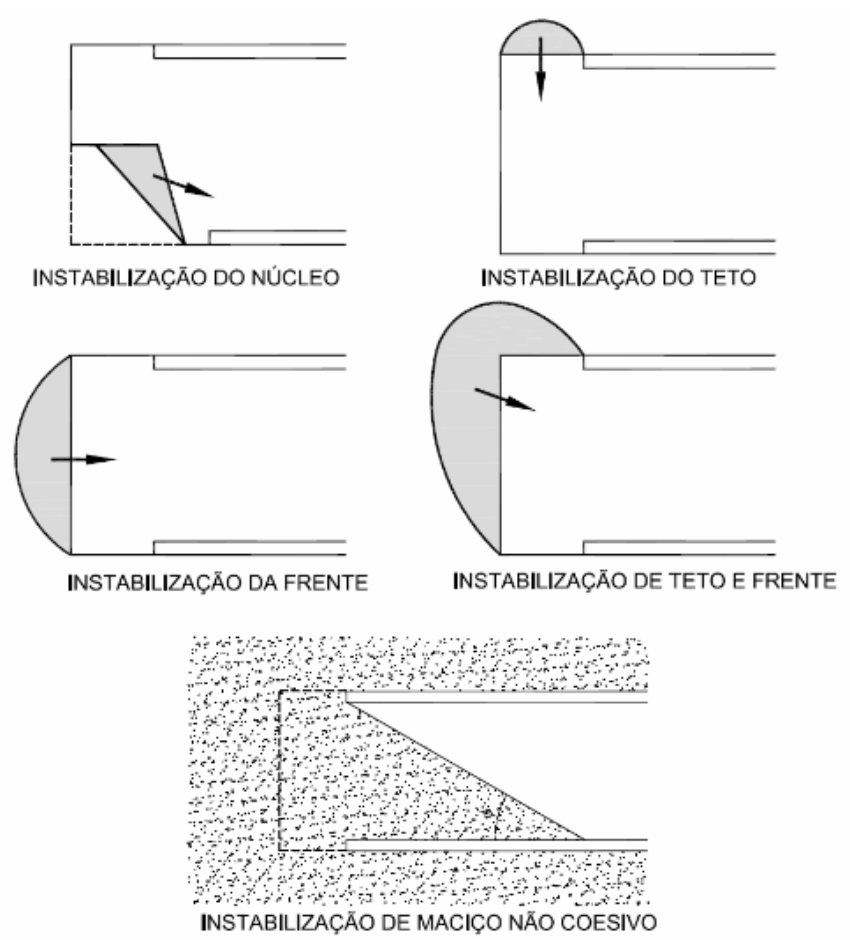

Figura 17 Principais tipos de mecanismos locais (copiado de "Instruções de projeto de túnel", DER, 2005 (11))

Os mecanismos nos suportes dos túneis ocorrem quando a solicitação da estrutura ultrapassa os seus limites de resistência, por carregamentos excessivos ou por falha no projeto ou execução do suporte. Carregamentos excessivos podem ser provocados por comportamentos imprevistos do maciço, ou por deformações impostas resultantes da alteração do estado de equilíbrio do conjunto maciçoestrutura provocadas pela escavação.

Os mecanismos que ocorrem nos suportes podem levar ao colapso da estrutura, e, sem as devidas intervenções, podem se tornar mecanismos globais.

Conforme a dissertação de Murakami (10), os mecanismos de ruptura nos suportes podem ser classificados em:

- Mecanismos no suporte sem arco invertido

Mecanismos causados por deficiência da fundação Mecanismos causados por flexão no revestimento 
- Mecanismos no suporte com arco invertido

Mecanismos provocados por flexão

Mecanismos provocados por cisalhamento

Os mecanismos provocados por cisalhamento podem ser consequências de deficiências no projeto ou na execução da obra. No projeto, a falha pode ocorrer no dimensionamento dos esforços, no detalhamento inadequado da ligação e na geometria desfavorável concebida.

Um dos pontos críticos para a ocorrência da ruptura por cisalhamento é na lateral da seção, onde ocorrem as juntas de concretagem entre a calota e o arco invertido. Essa região encontra-se próxima ao piso na fase de escavação da calota, fase em que ocorre acúmulo de sujeira e de material de reflexão.

Os principais tipos de ligação entre o arco invertido e a calota são apresentados na Figura 18. Como se pode observar, todos os detalhes dependem de uma boa aderência entre as diversas camadas de concreto projetado. $O$ mau desempenho das ligações pode resultar em colapsos da estrutura, muitas vezes sem aviso. A junta de concretagem tipo A é a mais adequada, pois transfere os esforços internos do revestimento por força normal, diferentemente dos outros tipos de junta.
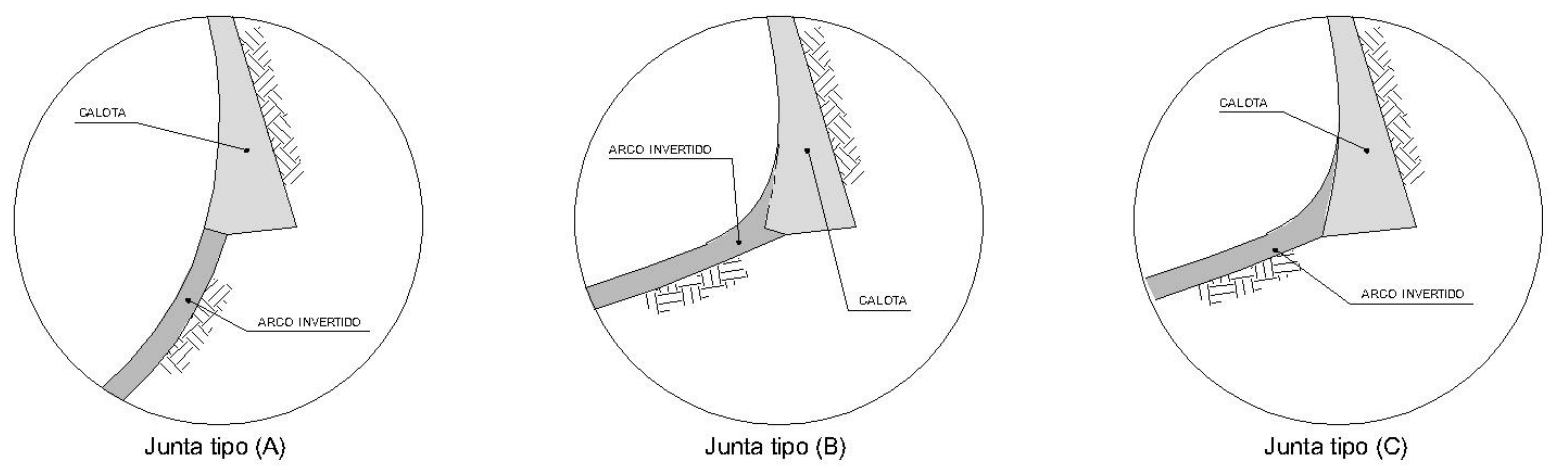

Figura 18 Principais tipos de junta de concretagem entre a calota e o arco invertido 


\subsection{ATO (Acompanhamento Técnico de Obra)}

Inicialmente, é fundamental destacar que toda obra de túnel deve ter um acompanhamento técnico de obra (ATO), realizado por equipe profissional especializada, que atue interativamente com o executor e o projetista. Para isso, esta atividade requer profissional ou equipe com conhecimentos teóricos e práticos da disciplina de túneis.

O projeto e construção de obras subterrâneas são geralmente associados a um nível elevado de riscos, por efeito de uma ampla gama de incertezas envolvidas em obras desse tipo. O ATO contribui significativamente para a mitigação de riscos do empreendimento.

No campo da Engenharia Geotécnica, no que se refere a obras de túneis, deve ser feito um acompanhamento sistemático efetivo e contínuo dos avanços das escavações, no sentido de compatibilizar e/ou fazer as adequações necessárias ao projeto, tendo em vista o comportamento e características dos maciços escavados, confrontados com os parâmetros e reações previstos no projeto.

Em outras palavras, isso requer um acompanhamento dos trabalhos de escavação e estabilização do maciço por meio de mapeamento e classificação geomecânica das frentes, acompanhando os avanços de modo a permitir um respaldo técnico que assegure a confiabilidade e segurança nas tomadas de decisões.

Usualmente, as atribuições de uma equipe de ATO são: adequação do processo construtivo, interpretação de dados de instrumentação, informação em tempo real da evolução da obra e ocorrências, análise do comportamento geral da obra, mapeamento geológico geotécnico, observação das condições de estabilidade de frente, verificação dos dispositivos de contenção, inspeção em estruturas lindeiras, pavimentos, redes de utilidade e galerias. 
A observação da formação de mecanismos de colapso durante a construção de túneis é uma das atividades mais importantes do acompanhamento técnico de obras ou ATO, pois aumenta a segurança da obra e permite definir os ajustes necessários para a adaptação do projeto à realidade. Todas as atividades do ATO têm sempre como foco evitar a formação dos mecanismos de colapso. Para tanto, o ATO deve ser realizado por equipes de engenheiros com profundos conhecimentos sobre 0 assunto.

Para orientar o trabalho na etapa de ATO, o projeto deve prover nos relatórios e desenhos a maior quantidade possível de informações relevantes, as quais servirão de base de conhecimento ao ATO, subsidiando as decisões a serem tomadas ao longo da obra.

Os projetos devem indicar, entre outras coisas, os principais aspectos do maciço identificados previamente a serem observados no campo, como propriedades e comportamento do maciço, níveis d'água etc.; todas as regras de aplicação de itens que dependam de alguma confirmação de campo para serem executadas, como tratamentos de maciço, mudanças de seção em razão do maciço, aplicação de drenagens no maciço, capacidade de carga do solo de fundação etc.; as adaptações necessárias para casos previsíveis de variação do maciço, nas seções de transição de maciço; os principais mecanismos de colapso potenciais que podem ocorrer durante a obra; eventuais pontos críticos de passagem do túnel, tais como proximidades com fundações, galerias, cabos energizados etc. 


\section{CARACTERÍSTICAS DA OBRA}

A obra objeto dos estudos deste trabalho faz parte da expansão da Linha 5 (Lilás) do Metrô de São Paulo, que será totalmente subterrânea. Conforme descrito no Relatório PBA (Plano Básico Ambiental) (12), a expansão está compreendida entre o Largo Treze e a Chácara Klabin, incluindo o Pátio Guido Caloi, e prevê a integração com a Linha 1 (Azul), na Estação Santa Cruz, e com a Linha 2 (Verde), na Estação Chácara Klabin. A extensão total será de $11,8 \mathrm{~km}$, dos quais $1,5 \mathrm{~km}$ será executado por meio do método NATM, 4,6 quilômetros de túneis de vias singelas por duas tuneladoras "Shield" de $\varnothing 6,9 \mathrm{~m}$ e $5,7 \mathrm{~km}$ de túneis de via escavados por uma tuneladora $\varnothing 10,6 \mathrm{~m}$. Haverá um total de 11 estações, 8 construídas em vala a céu aberto e 3 por método NATM.

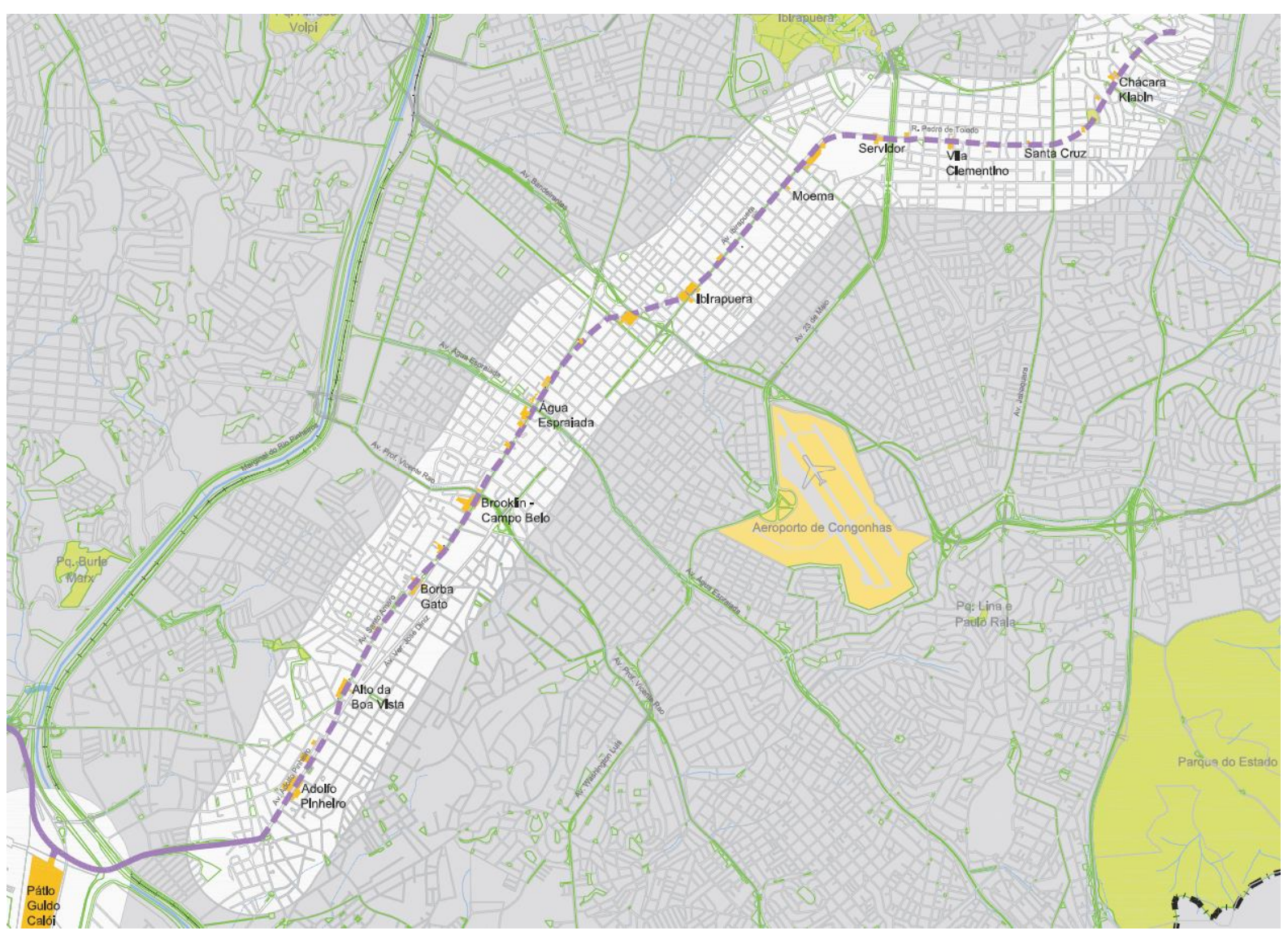

Figura 19 Locação da obra de expansão da Linha 5 (Lilás) do Metrô SP (PBA - Plano Básico Ambiental (12))

O início das obras da extensão da Linha 5 se deu no ano de 2009, por meio do Lote

1. Este trecho está compreendido entre o Largo Treze e a Praça Santa Cruz, possui 
aproximadamente $640 \mathrm{~m}$ de extensão e é constituído das seguintes unidades construtivas:

- Túneis de via (2 tramos que totalizam aproximadamente $500 \mathrm{~m}$ de extensão);

- Estação Adolfo Pinheiro (aproximadamente 140 m de extensão);

- Poço de ventilação e saída de emergência Delmiro Sampaio;

- Túnel de ligação (entre o poço de ventilação e o túnel de via).

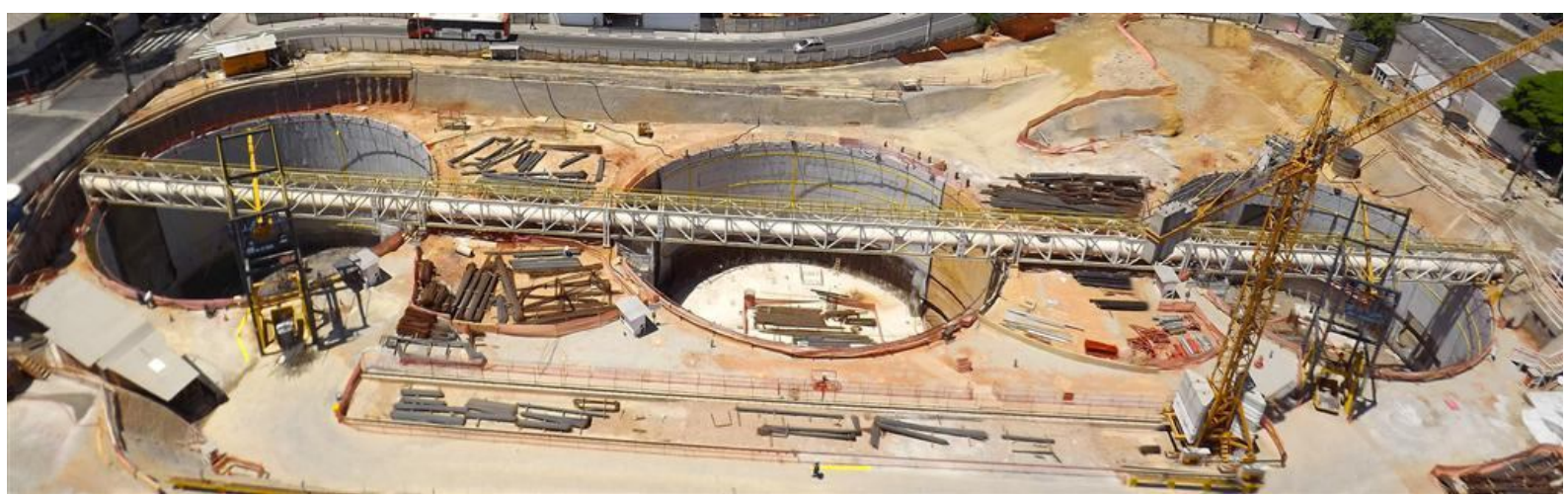

Figura 20 Construção da Estação Adolfo Pinheiro da Linha 5 (Lilás). Hugo Rocha (13)

A obra dos túneis de via do Lote 1 foi executada através de quatro emboques. Dois dos emboques foram executados através dos poços da estação Adolfo Pinheiro; os outros dois emboques foram executados através de um túnel de ligação, situado entre o poço de ventilação e saída de emergência Delmiro Sampaio e o túnel de via.

O acompanhamento e assistência técnica da obra bruta do Lote 1 da Linha 5 (Lilás) da Companhia do Metropolitano de São Paulo foi realizado por meio de de duas equipes: a primeira representando a projetista e a segunda representando 0 consórcio construtor. A equipe de ATO contratada pelo consórcio construtor foi constituída de engenheiro residente (Willian Carreira) e consultores em disposição parcial (Dr. Carlos Eduardo Moreira Maffei e Ma. Maria Cecilia Guazzelli). O serviço de ATO teve como objetivo análise dos resultados da instrumentação, análise técnica dos serviços especializados (métodos de escavação, caracterização geológico-geotécnica, tratamentos de maciço), proposição de alternativas mais seguras e/ou mais econômicas e realização de treinamento técnico das pessoas envolvidas na obra. 


\subsection{Estruturas}

\subsubsection{Estação Adolfo Pinheiro}

A Estação Adolfo Pinheiro situa-se na Avenida Adolfo Pinheiro, em Santo Amaro, entre as ruas Padre José de Anchieta e Isabel Schmidt. Essa área é densamente ocupada por estabelecimentos comerciais e de prestação de serviços, e próximo a Santa Casa de Misericórdia de Santo Amaro. Todos os trabalhos de escavação e contenção ocorreram com esses estabelecimentos em plena operação. A estação é constituída de cinco poços secantes com $33,58 \mathrm{~m}$ de diâmetro cada poço e aproximadamente $17,5 \mathrm{~m}$ de profundidade, escavados em solo. Os poços foram executados utilizando-se o sistema NATM, com revestimento em concreto projetado, telas de aço e tratamento do maciço com paredes diafragma "coulis". A estação possui dois acessos, um de cada lado da Avenida Adolfo Pinheiro, implantados perpendicularmente à avenida, na extremidade voltada para Rua Isabel Schmidt. Os acessos foram concebidos por meio do sistema cut and cover.

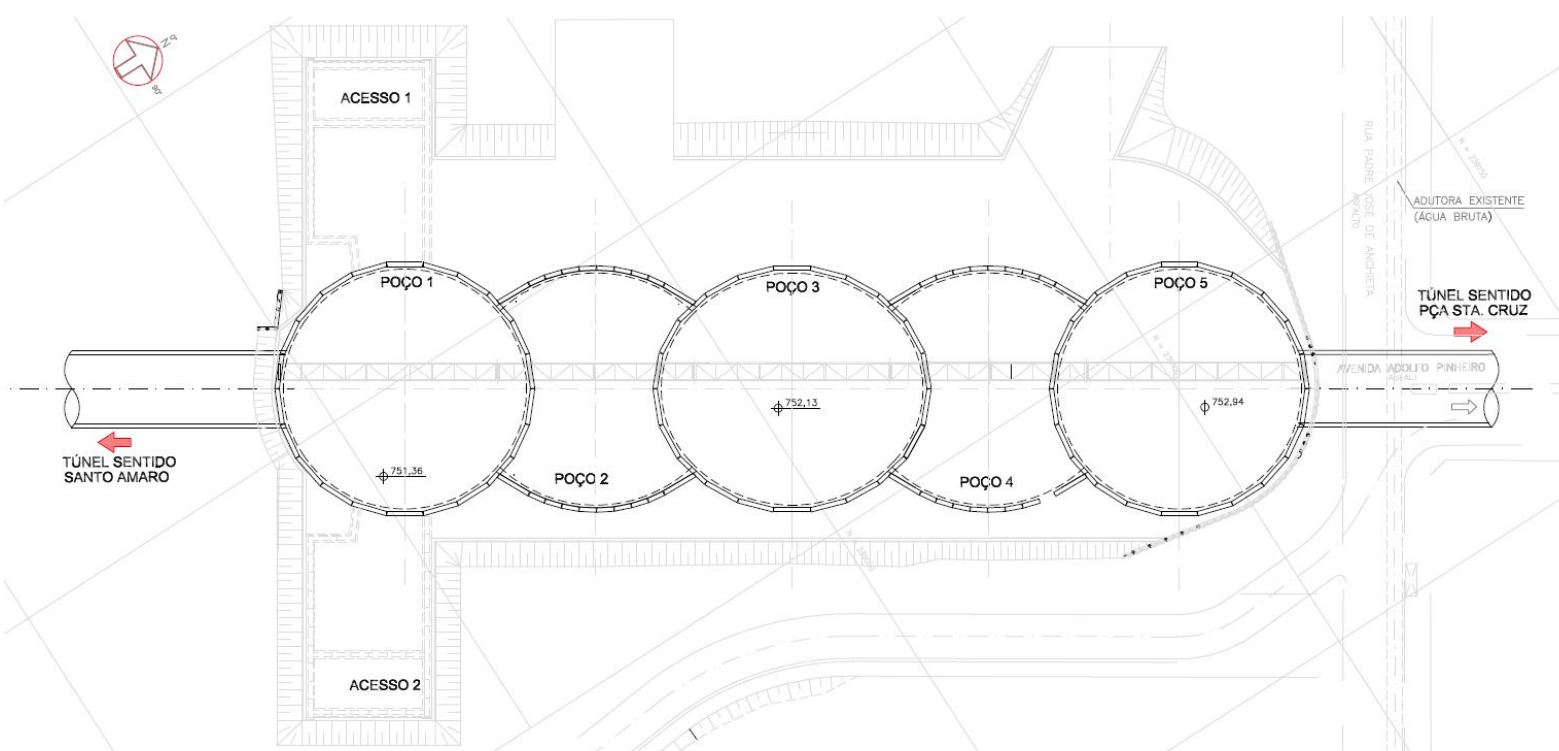

Figura $21 \quad$ Planta com a locação da Estação Adolfo Pinheiro da Linha 5 (Lilás) 
3.1.2. Poço de ventilação e saída de emergência Delmiro Sampaio

O poço de ventilação e saída de emergência Delmiro Sampaio está localizado a $326 \mathrm{~m}$ da estação Largo Treze e 320m da Estação Adolfo Pinheiro, na esquina da Rua Voluntário Delmiro Sampaio com a Av. Adolfo Pinheiro. A estrutura do poço é constituída basicamente de um poço circular com 12,0m de diâmetro e aproximadamente $27 \mathrm{~m}$ de profundidade, escavado em solo. Tal poço foi projetado utilizando-se o sistema não destrutivo NATM, com revestimento em concreto projetado e telas de aço.

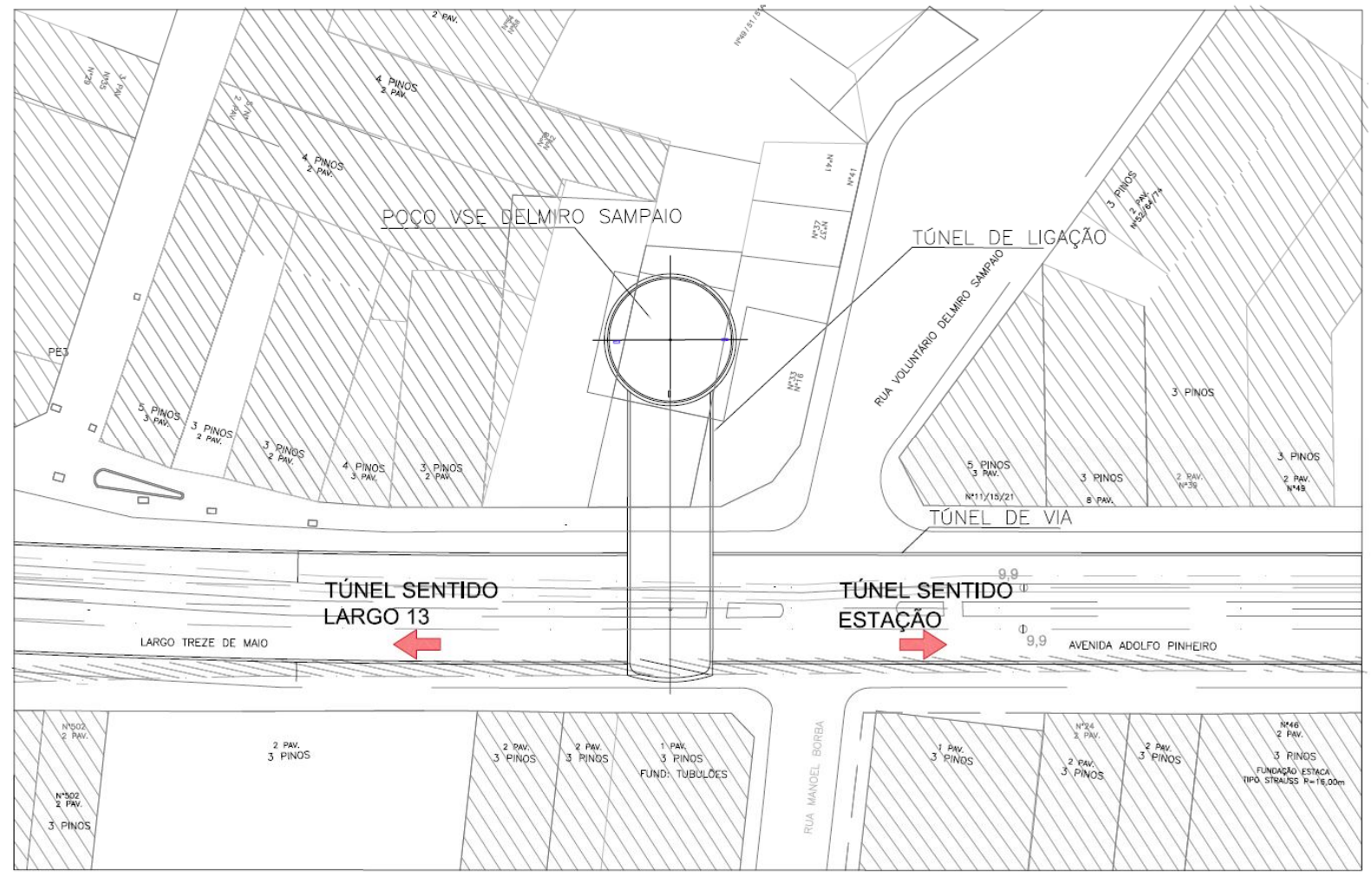

Figura 22 Poço de ventilação e saída de emergência Delmiro Sampaio

3.1.3. Túnel de ligação

Trata-se de um túnel em solo, em meio urbano, para interligar o poço de ventilação e saída de emergência Delmiro Sampaio e o túnel de via. Tal túnel foi executado pelo sistema não destrutivo NATM (revestimento em concreto projetado com cambotas treliçadas metálicas e telas de aço). O mesmo apresenta extensão aproximada de $28,0 \mathrm{~m}$ e seção transversal com área de $154,45 \mathrm{~m}^{2}$, com largura e altura da ordem de 
$11,7 \mathrm{~m}$ e $15,89 \mathrm{~m}$, respectivamente. A cobertura de solo sobre o túnel é de $14 \mathrm{~m}$, sem ocorrências de interrupção do tráfego existente, durante a sua execução. As contenções frontais para os emboques do túnel foram realizadas por meio de pregagens com barras de aço CA-50 e enfilagens tubulares injetadas no contorno.

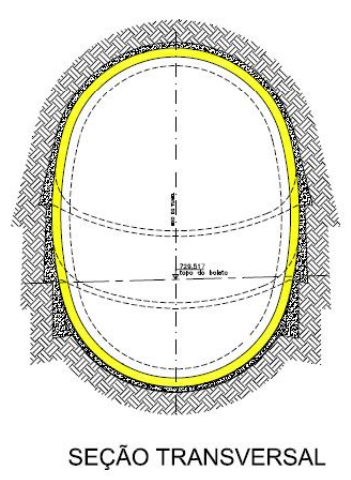

SEÇÃO TRANSVERSAL

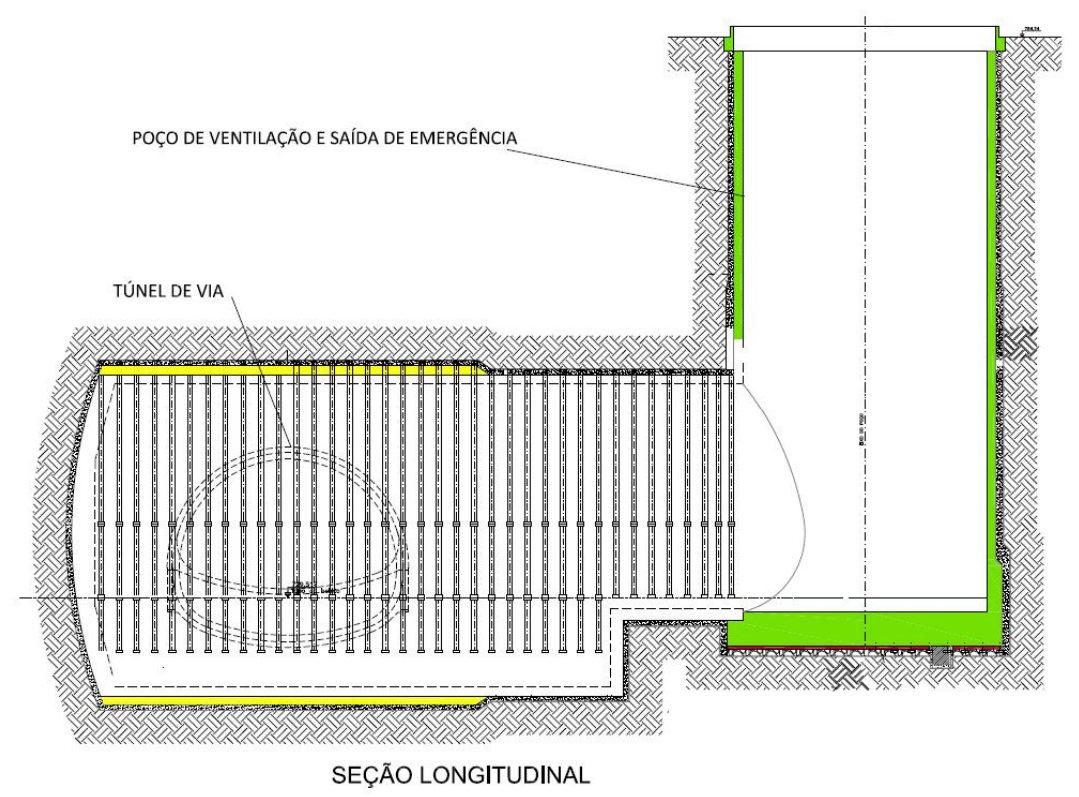

Figura 23 Túnel de ligação

3.1.4. Túnel de via

O túnel de via é dividido em dois trechos distintos de aproximadamente $400 \mathrm{~m}$ e $100 \mathrm{~m}$ de extensão. O primeiro trecho encontra-se entre o Largo 13 e a estação Adolfo Pinheiro, e o segundo trecho está localizado após a estação. A seção transversal do túnel é idêntica nos dois trechos, apresentando 9,03m de altura e $11,7 \mathrm{~m}$ de largura. A área da seção transversal do túnel de via é de $77,58 \mathrm{~m}^{2}$, e a cobertura média de solo sobre o túnel é de $15 \mathrm{~m}$, aproximadamente, projetados para serem executados pelo sistema não destrutivo NATM (revestimento em concreto projetado com cambotas treliçadas metálicas e telas aço).

Os túneis atravessaram maciços que variaram desde seções plenas em solo residual até seções plenas em solo do terciário de São Paulo, em meio urbano, sob a Av. Adolfo Pinheiro, área densamente ocupada por imóveis residenciais e estabelecimentos comerciais. Durante as obras, todas as edificações dessas áreas 
foram acompanhadas e, sempre que necessário, instrumentadas, de maneira a garantir a segurança de sua utilização e seu funcionamento.

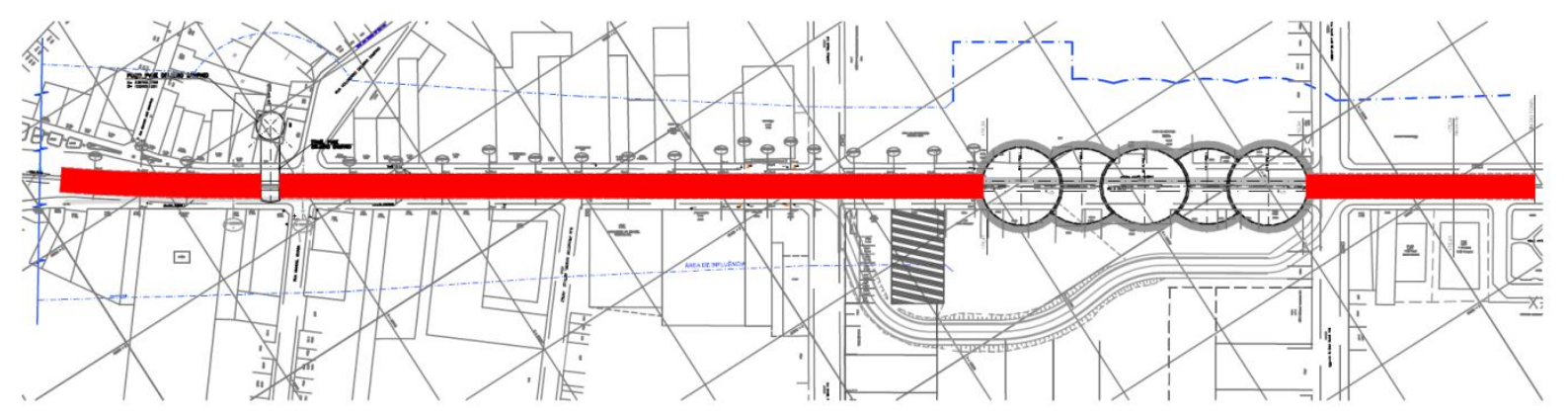

Figura 24 Túnel de via - Planta

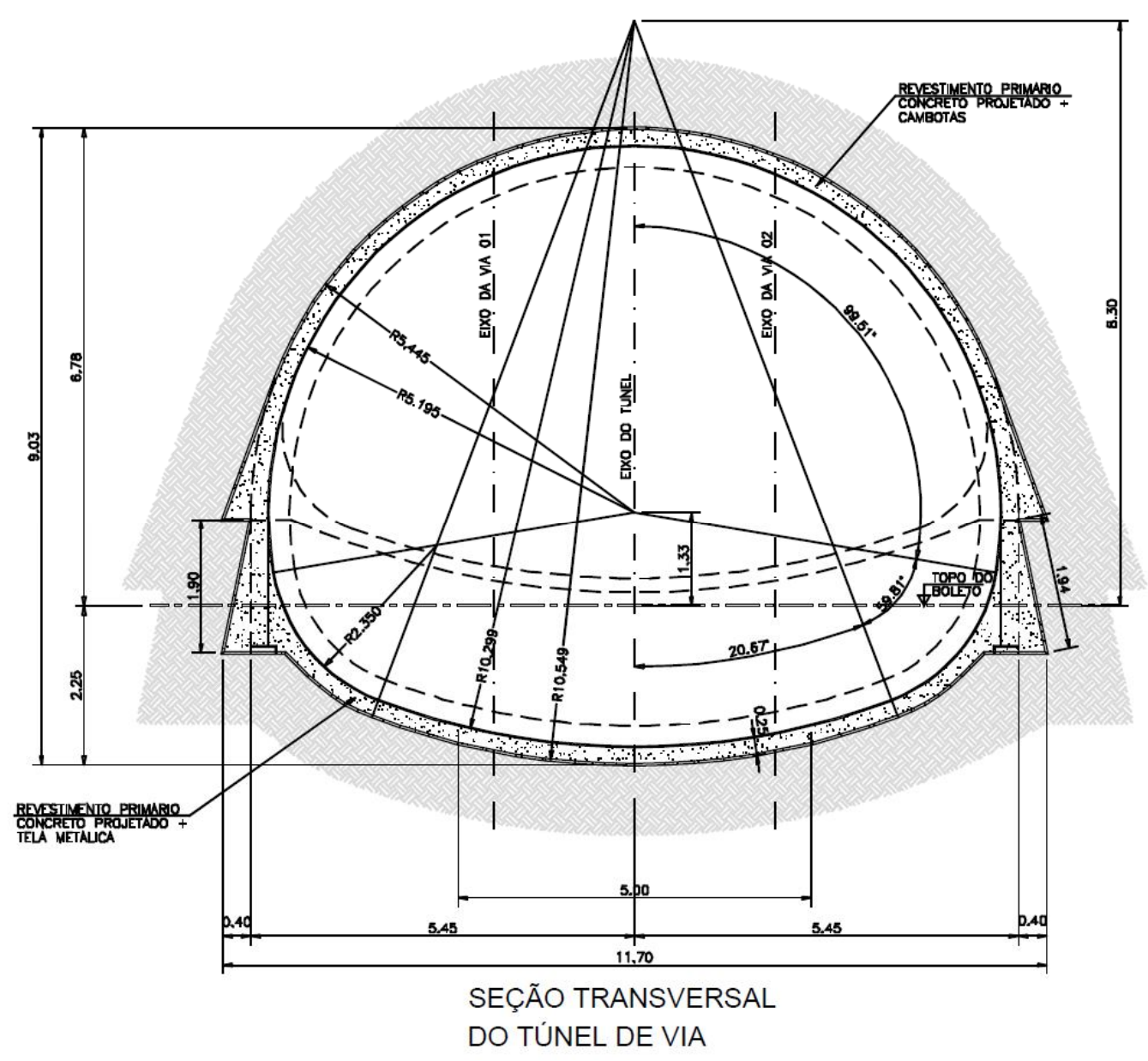

Figura 25 Túnel de via - Seção Transversal 


\subsection{Características geológico-geotécnicas}

Um projeto de túnel deve começar com uma investigação detalhada das condições do maciço. Um plano de investigação eficiente reduz o risco de deparar com condições do solo imprevistas. No entanto, atualmente, a investigação geotécnica é feita de modo pontual, por meio de perfurações no subsolo. Por se tratar de uma investigação pontual, as reais características do maciço são conhecidas somente no decorrer da execução do túnel. Em alguns casos, para obter maiores informações sobre o maciço a ser escavado, são utilizados furos de prospecção na frente de escavação ou túneis piloto. O túnel piloto tem dimensões menores, o que facilita na execução e pode detalhar as condições do maciço para escavação da unidade principal.

Conforme se pode observar no mapa a seguir, do relevo e geologia do Município de São Paulo, a região do projeto em questão situa-se na borda oeste da Bacia Sedimentar de São Paulo. Com relação aos materiais presentes nesta região, podem-se distinguir dois compartimentos geológicos: o Embasamento PréCambriano (solos residuais e saprolitos de gnaisses) e os sedimentos, representados pela Formação Resende e Formação São Paulo. 


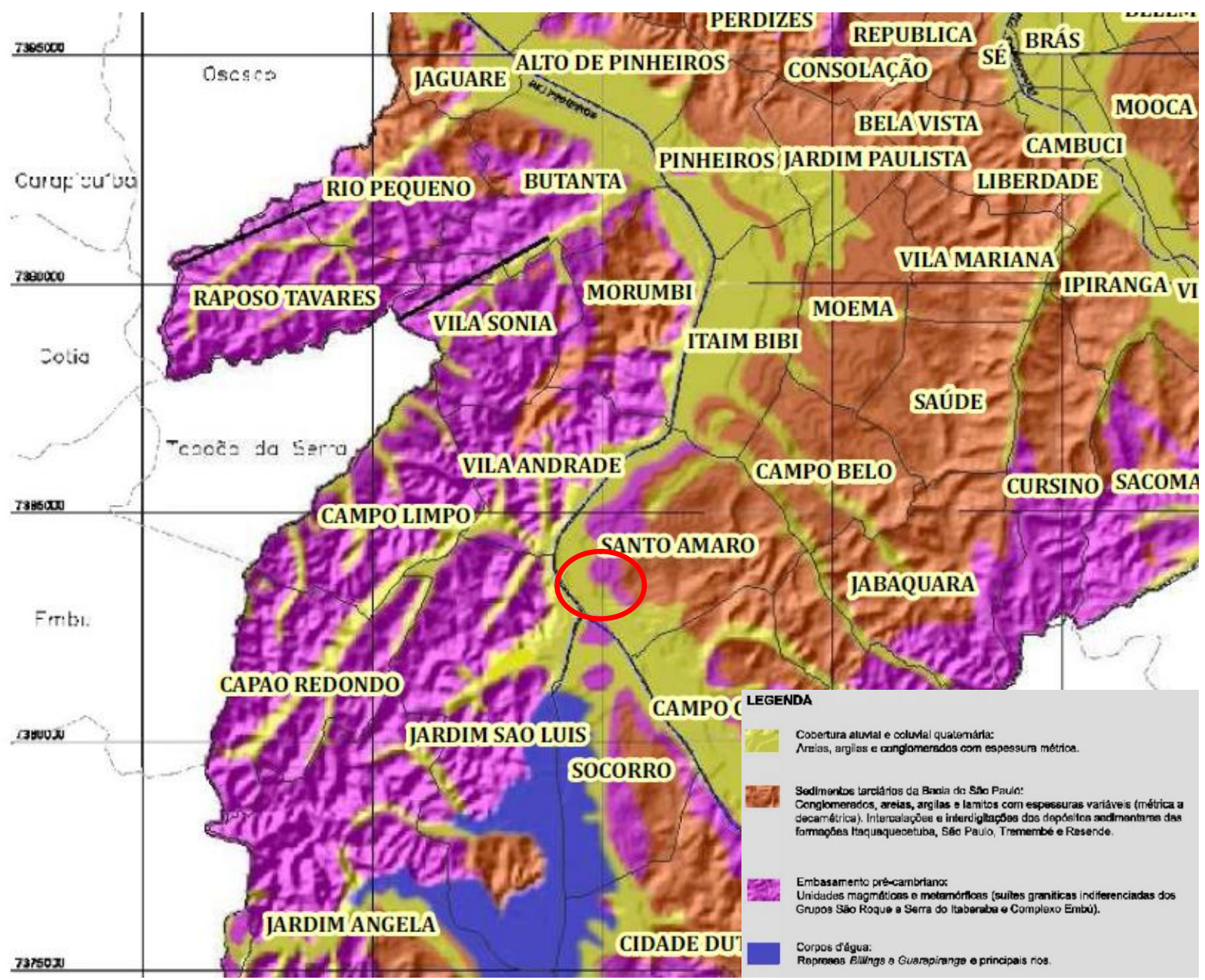

Figura 26 Mapa do Relevo e Geologia do Município de São Paulo (Prefeitura SP (14))

\section{Solos Residuais - Saprolitos de Gnaisses}

Ocorrem sotopostos aos sedimentos da Formação Resende e Formação São Paulo, constituem horizontes de materiais associados a espessos perfis de intemperismo condicionados a inúmeras estruturas geológicas (foliação metamórfica, fraturas e zonas de cisalhamento) decorrentes de sucessivos eventos tectônicos do período pré-cambriano e, posteriormente, submetidos a eventos de reativação condicionantes para a formação da própria bacia sedimentar. Tais materiais apresentam valores de SPT que aumentam com a profundidade até atingir o impenetrável a este método de investigação.

Observa-se a seguir como o geólogo L. F. Vaz (15) descreve os horizontes de alteração de rocha ("Saprolito"). 
"O horizonte denominado solo de alteração para caracterizar a camada que se encontra ainda em processo de alteração intempérica, onde os processos pedogênicos são incipientes ou muito limitados. Esse horizonte é também chamado de saprolito e de solo residual jovem.

O solo de alteração é sempre heterogêneo em relação à cor, textura e composição mineralógica. Esta heterogeneidade é decorrente da manutenção do arranjo dos minerais segundo a disposição original da rocha matriz, fazendo com que os minerais do solo ocupem os mesmos lugares e posições exibidos na rocha original. Além disso, as eventuais estruturas presentes na rocha encontram-se preservadas no solo de alteração, significando que os planos constituídos por tais estruturas permanecem e são reconhecíveis no solo. As estruturas das rochas usualmente preservadas no solo de alteração são: a xistosidade, estratificação, fraturas, falhas, dobras e contatos.

A heterogeneidade e a anisotropia dos solos de alteração são facilmente constatadas pela típica coloração variegada desses solos. A cor pode apresentar-se aparentemente homogênea quando se tratar de solos derivados de rochas de granulação fina, desprovidas de estruturas. Nesses casos, entretanto, o exame com lupa revelará a preservação da textura original da rocha.

A mineralogia dos solos de alteração é constituída por argilo-minerais neo-formados e minerais de rocha em processo de alteração química para argilo-minerais. Os minerais de rocha quimicamente inertes, como o quartzo, encontram-se apenas mais fragmentados do que na rocha."

\section{Sedimentos da Formação Resende}

A Formação Resende é constituída principalmente de depósitos de leques aluviais, conforme Riccomini (16). Nos depósitos de fácies proximal predominam conglomerados polimíticos, brechas e diamictitos, enquanto os depósitos de fácies distal constituem-se predominantemente de lamitos, podendo ocorrer lentes arenosas e conglomerados de sistema fluvial entrelaçado.

Os sedimentos de idade terciária da Formação Resende são constituídos de camadas de argilas rijas de coloração cinza e amarela e areias compactas. As 
argilas, com fração silto-arenosa pouco significativa, de alta consistência e baixa permeabilidade, constituem materiais cujas características geotécnicas se refletem em maciços muito favoráveis à escavação subterrânea. As areias, em geral, são de granulometria média e ocorrem em lentes confinadas.

\section{Sedimentos da Formação São Paulo}

A Formação São Paulo corresponde a depósitos de sistema fluvial meandrante, sendo constituída de argilas vermelhas e amarelas, siltosas pouco arenosas, de consistência variada; de argilas siltosas pouco arenosas, variegadas, de consistência variada e de areias finas e médias argilosas vermelhas e amarelas.

De acordo com Riccomini (16), a Formação São Paulo está associada ao ambiente sedimentar do tipo fluvial meandrante. São sedimentos que ocorrem, em geral, acima da cota $750 \mathrm{~m}$, podendo alcançar a cota $820 \mathrm{~m}$. É bastante afetada pelo intemperismo e fenômeno de laterização, apresentando elevadas concentrações de óxido de ferro.

Sobrepostas ao horizonte das argilas variegadas encontram-se as argilas porosas vermelhas. São sedimentos notadamente submetidos a intenso processo de intemperismo e laterização, potencialmente colapsíveis, que estabelecem baixa capacidade de carga, que tende a aumentar quando compactados.

\section{Perfil Geológico}

Por meio da campanha de sondagens realizada para caracterizar o maciço da região, documentada no Relatório Geológico-Geotécnico (17), pode-se resumir a geologia do trecho da seguinte forma:

A base do perfil geológico investigado é constituída de solos residuais jovens (5SR2) e maduros (5SR1), oriundos da alteração de gnaisses graníticos, com valores de NSPT crescentes com a profundidade e superiores a 25 golpes, de permeabilidade elevada. Sobre essa camada, encontram-se sedimentos da Formação Resende.

A partir do túnel de ligação, sentido estação Adolfo Pinheiro, o horizonte de solo de alteração de gnaisse granítico mergulha, dando lugar para as argilas duras (4Ag2) e areias compactas (4Ar2), com valores elevados de NSPT, da Formação Resende, 
que acompanham o piso da geratriz inferior do túnel de via no sentido Estação Adolfo Pinheiro.

De forma localizada, abaixo da cota $730,00 \mathrm{~m}$, verificou-se a ocorrência de sedimentos típicos de borda de bacia (lamitos; 4Ag3), constituídos de argila arenosa dura, pouco siltosa, com pedregulhos variados.

Sobre as camadas da Formação Resende, encontram-se os sedimentos da formação São Paulo, constituída por camadas de argila e areia. As camadas arenosas (3Ar1 e 3Ar2) apresentam compacidade variável. As camadas de argila (3Ag1 e 3Ag2) apresentam consistência crescentes com a profundidade e nas camadas superficiais. Junto à estação Adolfo Pinheiro, encontram-se argilas porosas vermelhas (3AgP1 e 3AgP2).

Conforme ilustrado nos desenhos do perfil geológico a seguir, as sondagens e piezômetros instalados indicam a ocorrência de dois níveis de água ao longo do desenvolvimento do trecho. A ocorrência de dois níveis é mais caracterizada nas proximidades da Estação Adolfo Pinheiro, onde é possível observar distinção da carga piezométrica nas camadas de areia situadas na cota de fundo dos poços da estação e nas camadas de areia logo abaixo da camada de argila porosa junto à superfície. Ocorrem, também, bolsões de areias saturadas no meio das argilas. 

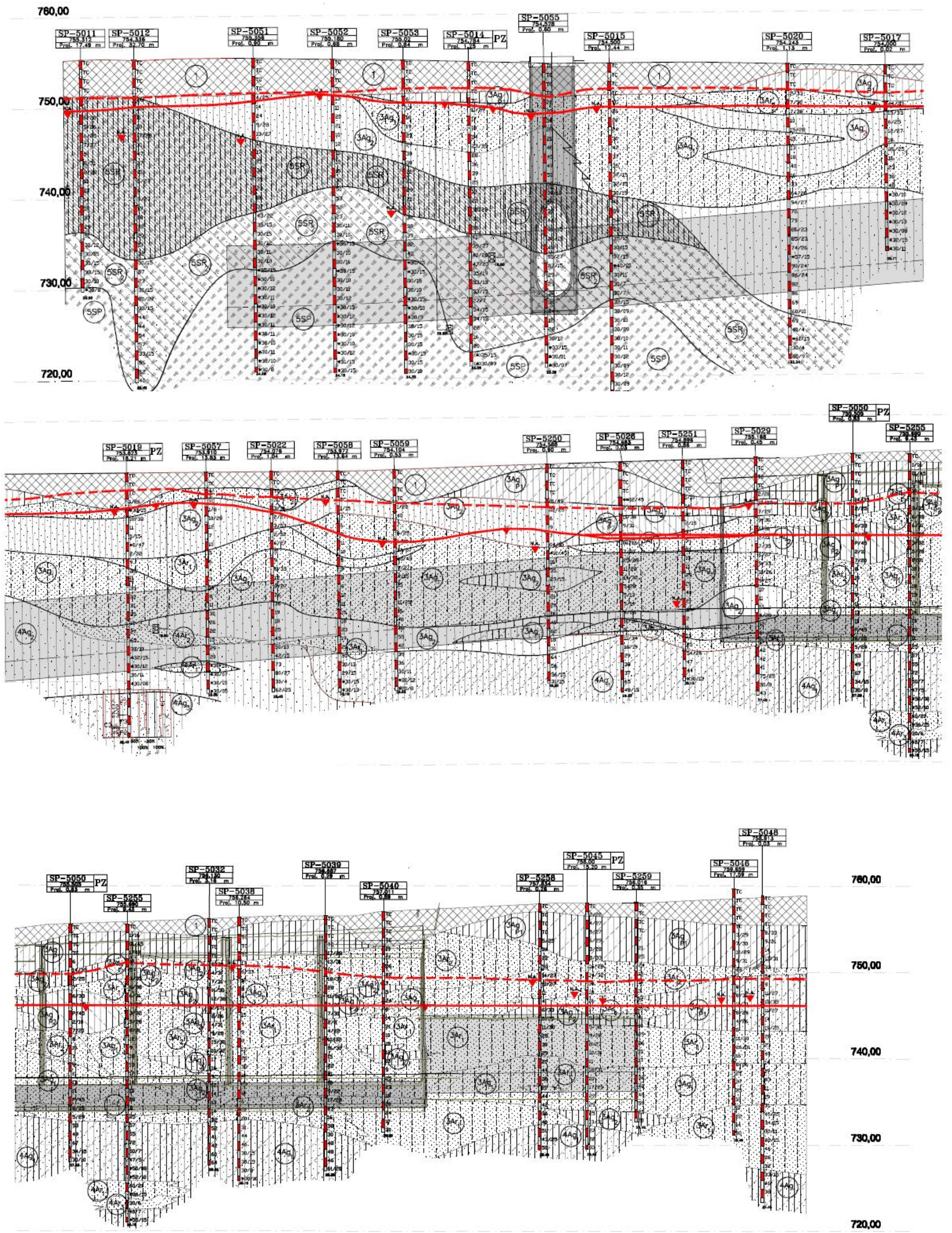

Figura 27 Perfil geológico (desenhos obtidos a partir dos perfis de projeto) 
Apresentam-se a seguir os parâmetros geotécnicos sugeridos para a elaboração dos projetos do Trecho Largo Treze - Borba Gato.

Correlações e informações obtidas por meio da literatura e ensaios, para os depósitos tecnogênicos e sedimentos terciários, foram compiladas nas tabelas apresentadas no Relatório Geológico-Geotécnico (18) (RT-4.08.00.00/4C3- 002 Promon Engenharia Ltda., 1994). Tais parâmetros, apresentados na tabela a seguir, foram adotados para o projeto da Linha 4 do Metrô de São Paulo e são sugeridos para as obras do Trecho Largo Treze - Borba Gato.

\begin{tabular}{|c|c|c|c|c|c|}
\hline $\begin{array}{l}\text { UNIDADES } \\
\text { GEOLÓGICAS }\end{array}$ & $\gamma\left(\frac{t f}{m^{3}}\right)$ & $c^{\prime}\left(\frac{t f}{m^{2}}\right)$ & $\varphi\left(^{\circ}\right)$ & $k_{0}$ & $E_{0}(M P a)$ \\
\hline \multicolumn{6}{|c|}{ DEPósitos TECNOGÊNICOS } \\
\hline AT & 1,6 & 1 & 20 & 0,83 & $8-28$ \\
\hline \multicolumn{6}{|c|}{ FoRMAÇÃo SÃo PAULO (TERCIÁRIO) } \\
\hline $3 \mathrm{Ag}_{\mathrm{p} 1}$ & $1,45-1,6$ & 2 & 27 & 0,6 & $10-30$ \\
\hline $3 \mathrm{Ag}_{\mathrm{p} 2}$ & $1,6-1,8$ & 4 & 25 & 0,6 & $35-80$ \\
\hline $3 \mathrm{Ag}_{1}$ & $1,7-2$ & $7,5-10$ & 22 & $0,8-1$ & $50-200$ \\
\hline $3 \mathrm{Ag}_{2}$ & $1,7-2$ & $4-10$ & 24 & $0,8-1$ & $30-175$ \\
\hline $3 \mathrm{Ar}_{1}$ & 1,9 & 0,3 & $30-35$ & $0,87-0,54$ & $20-200$ \\
\hline $3 \mathrm{Ar}_{2}$ & 1,6 & 0,1 & $30-35$ & $0,87-0,54$ & $50-175$ \\
\hline \multicolumn{6}{|c|}{ FORMAÇÃo RESENDE (TERCIÁRIO) } \\
\hline $4 \mathrm{Ag}_{1}$ & $1,88-2,16$ & $4-10$ & 24 & 0,8 & $40-170$ \\
\hline $4 \mathrm{Ag}_{2}$ & $1,88-2,16$ & $4-10$ & 24 & 0,8 & $40-80$ \\
\hline $4 \mathrm{Ag}_{3}$ & $1,88-2,16$ & $>2,5$ & 27 & 0,8 & $180-360$ \\
\hline $4 \mathrm{Ar}_{1}$ & $1,87-2,06$ & 0,1 & $30-35$ & 0,8 & $40-150$ \\
\hline
\end{tabular}




\begin{tabular}{|c|c|c|c|c|c|}
\hline $\mathbf{4 A r}_{2}$ & $1,87-2,06$ & 0,1 & $30-40$ & 0,8 & $50-350$ \\
\hline $\mathbf{4 A r _ { 3 }}$ & $1,87-2,06$ & 0,1 & $30-40$ & 0,8 & $30-200$ \\
\hline \multicolumn{7}{|c|}{ EMBASAMENTO CRISTALINO (PRÉ-CAMBRIANO) } & $30-70$ \\
\hline $\mathbf{5} \mathbf{S R}_{\mathbf{1}}$ & 1,8 & 1,5 & $25-30$ & - & $70-100$ \\
\hline $\mathbf{5} \mathbf{S R}_{\mathbf{2}}$ & 1,9 & 2 & 35 & - & $100-200$ \\
\hline $\mathbf{5 S P}$ & 2 & $1-2$ & $35-40$ & - & \\
\hline
\end{tabular}

Tabela 2 - Parâmetros Geotécnicos

Onde:

$\gamma$ - peso especifico do material;

$c$ - coesão;

$\varphi$ - ângulo de atrito;

$k_{0}$ - coeficiente de empuxo em repouso;

$E_{0}$ - modulo de elasticidade.

\subsection{Método executivo do túnel de via}

No presente item, pretende-se enumerar a sequência executiva do túnel de via.

1- Execução do tratamento de emboque (enfilagens e pregagens);

2- Demolição do revestimento primário, do túnel de ligação ou poço da estação, na região da calota, seguindo a geometria da seção do túnel de via, preservando a região do núcleo frontal, até atingir o avanço de 0,6m;

3- Aplicação de camada de concreto projetado com $0,03 \mathrm{~m}$ de espessura (a espessura final do revestimento primário é $25 \mathrm{~cm}$ );

4- Instalação da primeira cambota e execução da camada de concreto projetado até a espessura final do revestimento primário;

5- Repetir o procedimento para instalação da segunda cambota. Passo de 
avanço 0,6m;

6- Escavação de um lance de $0,8 \mathrm{~m}$, dando conformação ao núcleo frontal;

7- Aplicação de camada de concreto projetado com 0,03m de espessura;

8- Instalação da cambota e execução da camada de concreto projetado até a espessura final do revestimento primário;

9- Repetição dos itens 6 a 8, por seis avanços;

10-Demolição do revestimento primário, do túnel de ligação ou poço da estação, na região do núcleo frontal e do arco invertido provisório;

11-Escavação do núcleo frontal mantendo inclinação de 1h:3v, deixando uma plataforma mínima de 1,60m;

12-Escavação do arco invertido provisório em lance de 2,4m;

13-Aplicação de concreto projetado em camadas sucessivas de 0,05m até a espessura de 0,17m; instalação de tela metálica (L-283); Incorporação da tela metálica com concreto projetado até a espessura final de $0,2 \mathrm{~m}$;

14-Após quatro horas de cura do concreto projetado, execução do aterro para proteção e tráfego;

15-Repetição dos itens 6 a 8, por três avanços;

16-Repetição dos itens 11 a 14;

17-Repetição dos itens 15 a 16, até o encontro com a outra frente de escavação ou final do trecho;

18-Demolição do arco invertido provisório, nas regiões laterais do rebaixo, seguindo a geometria da seção para implantação do arco invertido definitivo;

19-Escavação em nichos laterais, com avanços de 3 cambotas;

20-Aplicação de uma camada de 0,04m de concreto projetado, instalação dos seguimentos das três cambotas e incorporação com concreto projetado até atingir a espessura final;

21-Demolição do arco invertido provisório, na região central do rebaixo, seguindo a geometria da seção para implantação do arco invertido definitivo;

22-Escavação do trecho central, com avanços de 3 cambotas;

23-Aplicação de concreto projetado em camadas sucessivas de 0,05m até a espessura de 0,22m. Instalação de tela metálica (L-283). Incorporação da tela metaliza com concreto projetado até a espessura final de $0,25 \mathrm{~m}$; 
24-Repetição dos itens 18 a 23, até o final do trecho;

25-Execução da impermeabilização e revestimento secundário.

Os tratamentos do maciço: drenos horizontais profundos, enfilagens e pregagens são de caráter eventual, em função das características do maciço, cuja necessidade foi arbitrada pela equipe de ATO, no decorrer da execução das escavações.

\subsection{Sistema de tratamento do maciço (túnel de via)}

\subsubsection{Sistema de rebaixamento do lençol freático}

A percolação de água através do solo não pode prejudicar a qualidade e a segurança da obra, nem impedir o acesso à mesma.

O sistema de controle da água subterrânea tem por finalidade diminuir ou anular a influência da subpressão na frente de escavação e no revestimento de primeira fase do túnel de via. A estrutura definitiva foi dimensionada para suportar os esforços decorrentes da sub-pressão. Nesta obra foi adotado o sistema de rebaixamento do lençol freático por meio de poços com bombas submersas (PBS). No total, foram utilizados aproximadamente 206 poços, ao longo de toda a obra. Os poços foram instalados nas duas laterais do túnel, com espaçamento de 6,0m entre os poços e a $1,0 \mathrm{~m}$ do revestimento do túnel. A profundidade média de instalação dos poços é de $45,0 \mathrm{~m}$. Maiores detalhes da instalação podem ser observados na figura a seguir. Nos casos em que os poços com bombas submersas não foram suficientes para garantir uma escavação segura, foram adotados, de forma adicional, drenos subhorizontais instalados na frente de escavação. 


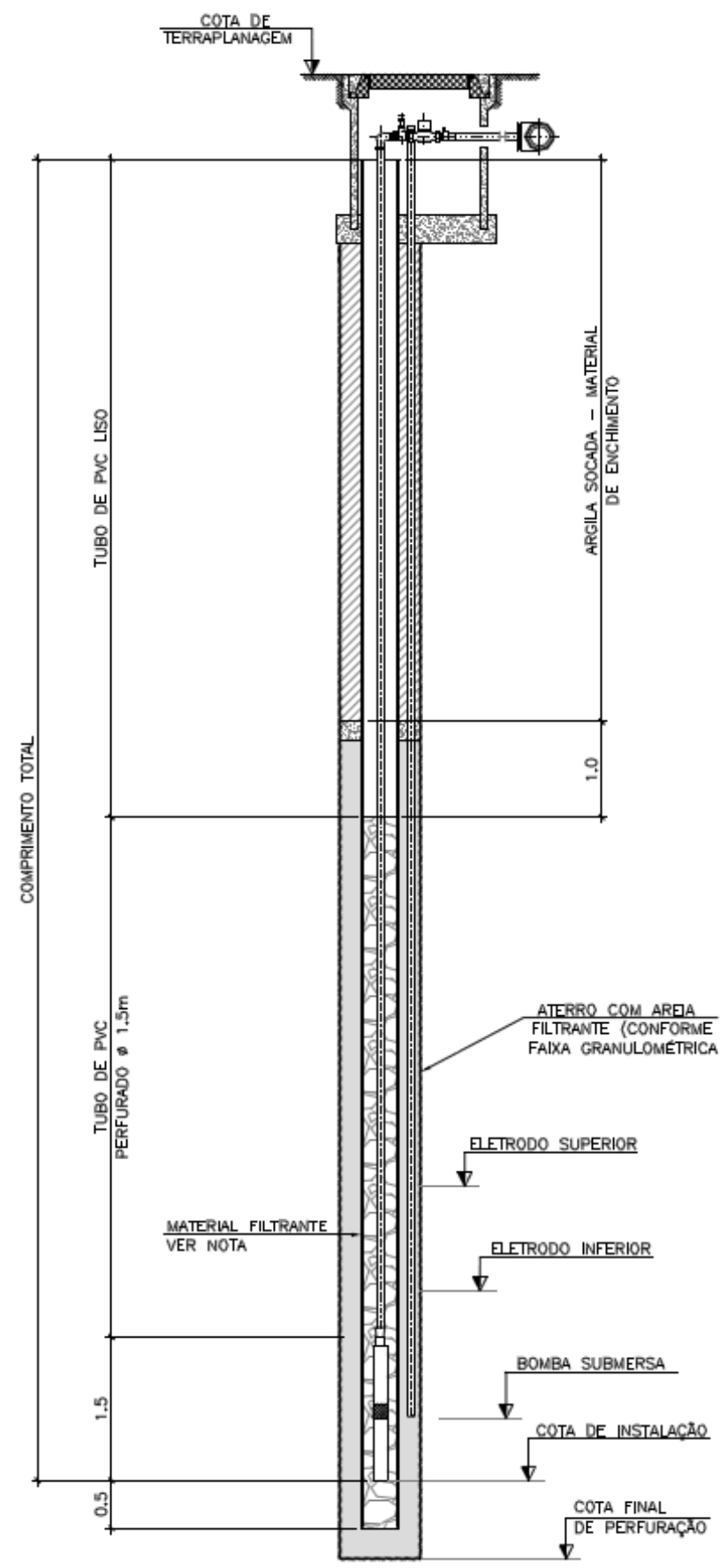

Figura 28 Detalhe de instalação dos poços com bombas submersas (PBS's)

3.4.2. Pregagens de frente

Tradicionalmente, são três os materiais utilizados nas pregagens de frente: barras aço, fibra de vidro e colunas de solo-cimento horizontais com intrusões rígidas, sendo que o primeiro apresenta dificuldade para remoção no decorrer da escavação. 
Em função das dimensões do túnel, das características do maciço, do método construtivo e das condições de drenagem, o projeto adota pregagens de frente através de colunas de solo-cimento horizontais com barras de PVC rígido ou pregagens injetadas, quando necessário, para melhorar as condições de estabilidade da frente de escavação. A aplicação das pregagens de frente foi eventual e em trechos localizados, em função do comportamento do maciço perante a escavação.

\subsubsection{Enfilagens}

A estabilidade do teto pode envolver um vão longitudinal maior do que o avanço, correspondente à distância entre a frente e o suporte resistente. Com a finalidade de melhorar a estabilidade local na calota do túnel de via, o projeto prevê dois tipos de enfilagem, em função das características do maciço. Os tipos de enfilagens são: 1Colunas de solo-cimento, utilizadas em maciços arenosos e com baixa resistência e 2- Enfilagens formadas por tubos de aço (Schedule) com válvulas-manchete, utilizadas em maciços argilosos e com alta resistência. No caso do uso de válvulasmanchete, a injeção de nata de cimento obedeceu a critérios de injeção (volume e pressões) definidos no projeto.

As enfilagens foram utilizadas obrigatoriamente nos emboques e no restante do túnel de via, sua aplicação foi eventual, em função do comportamento do maciço perante a escavação. 


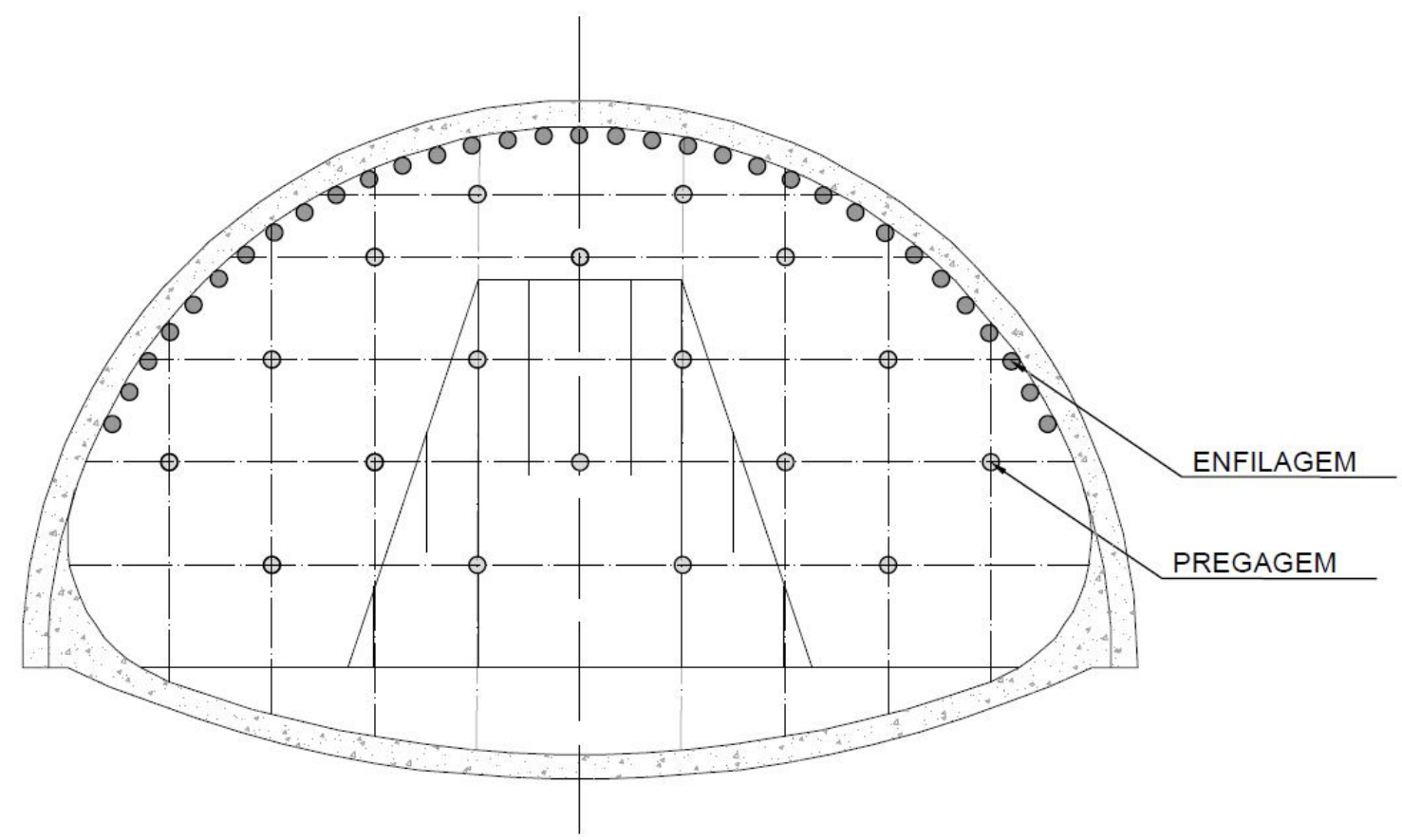

Figura 29 Seção transversal com a locação das enfilagens e pregagens

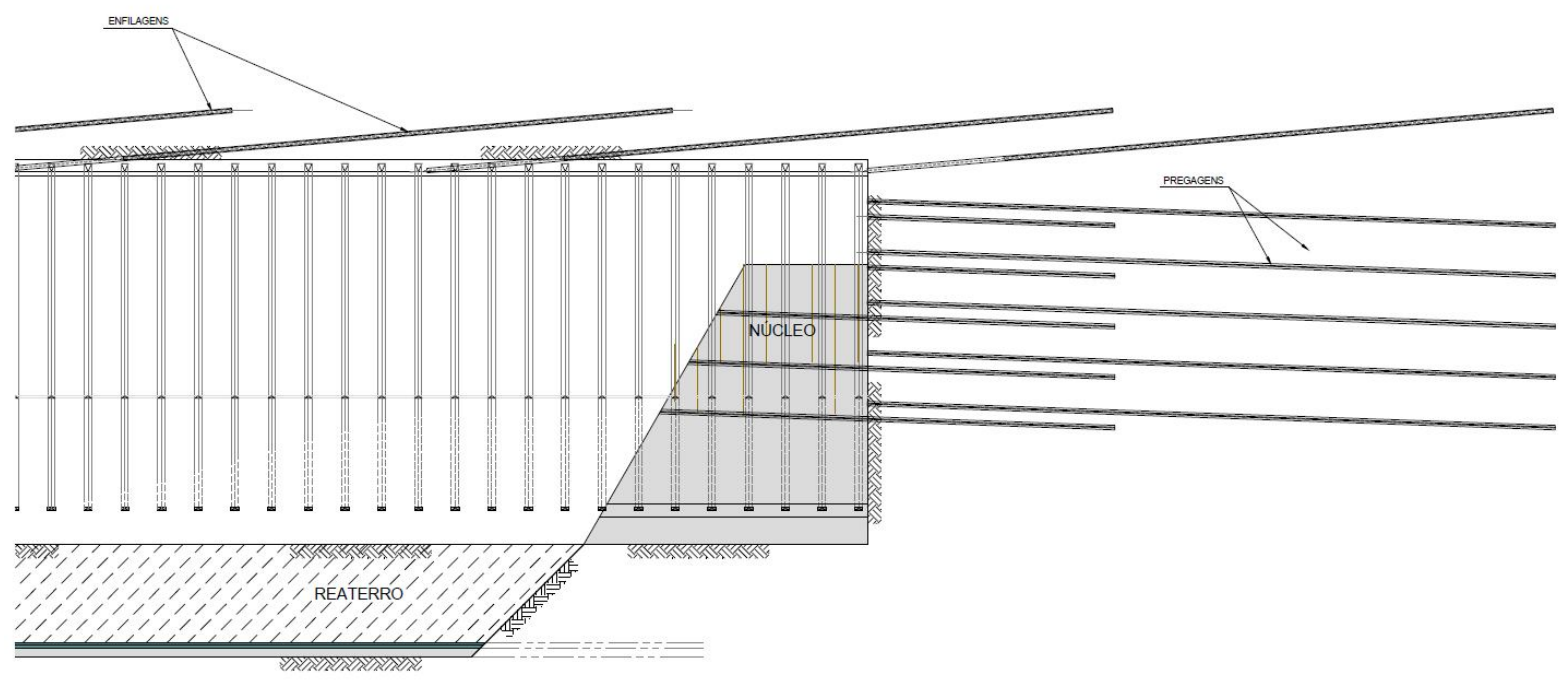

Figura 30 Seção longitudinal com a locação das enfilagens e pregagens 


\subsection{Instrumentação (túnel de via)}

A instrumentação do maciço e das estruturas visa observar a adequação da metodologia construtiva dos sistemas de suporte e o fator de segurança em torno da escavação do túnel de via compreendido entre o Largo Treze e a Praça Santa Cruz. Dessa maneira, permite avaliar as deformações e deslocamentos induzidos pela execução da obra, e permite a decisão pela adoção de medidas adicionais de segurança, caso as deformações observadas comprometam a integridade das estruturas, formando mecanismos de ruptura.

A instrumentação adotada para o túnel de via é composta dos seguintes instrumentos:

- Marcos superficiais

- Tassômetros

- Pinos de convergência e nivelamento da estrutura do túnel

- Piezômetros

- Pinos em edificações

Para instrumentação do túnel de via foram adotados dois tipos de seção instrumentada. A seção "Tipo A" é composta de cinco marcos superficiais "MS", quatro tassômetros "TS" (sendo um sobre a adutora existente) e cinco pinos de convergência e nivelamentos "P", conforme mostra a Figura 31. A seção "Tipo B" é composta de três marcos superficiais "MS", dois tassômetros "TS" (sendo um sobre a adutora existente) e cinco pinos de convergência e nivelamentos "P", conforme mostra a Figura 32. Os emboques do túnel foram instrumentados por meio de seções Tipo A. 


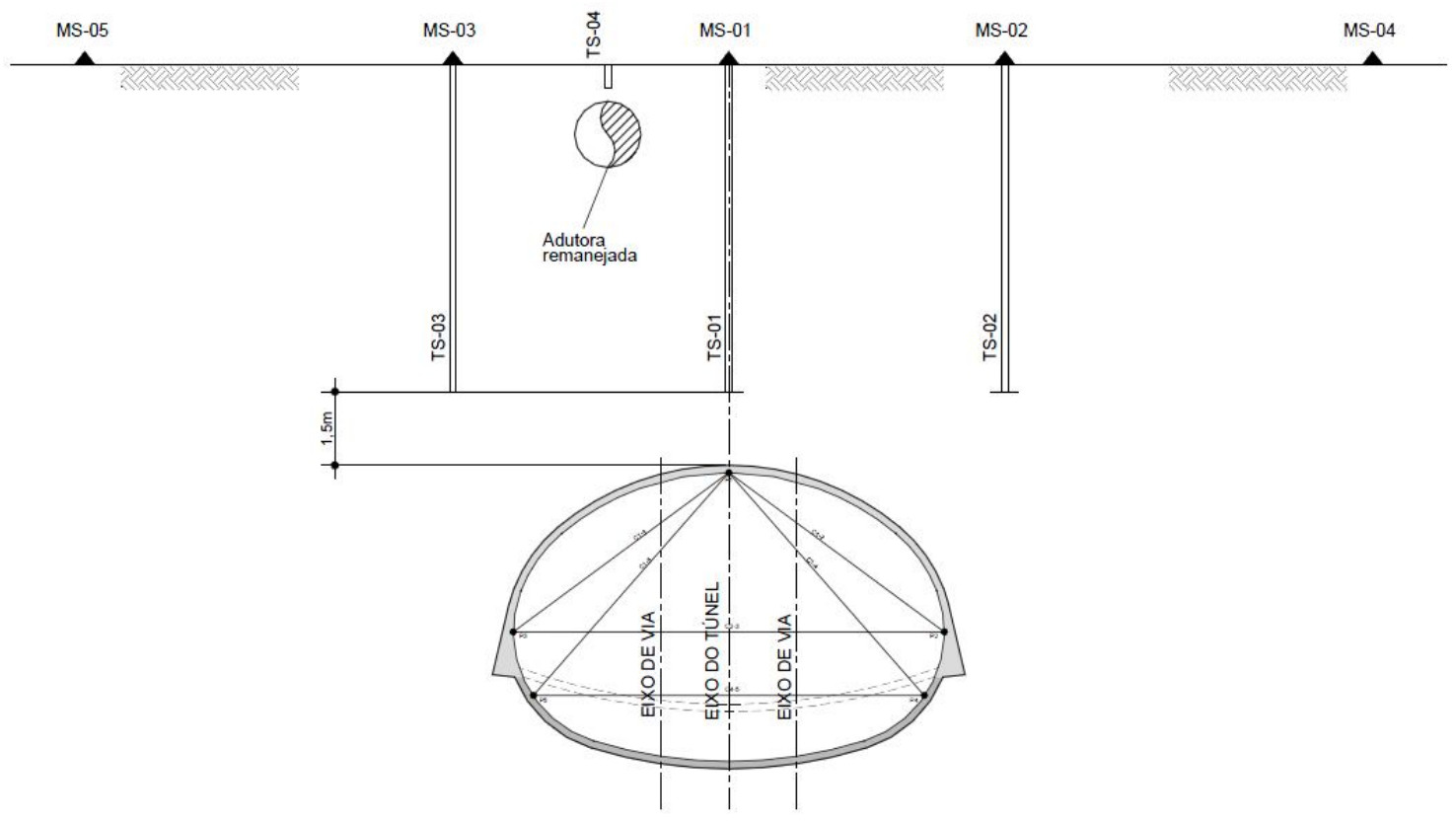

Figura 31 Seção típica de instrumentação do túnel de via - seção Tipo A

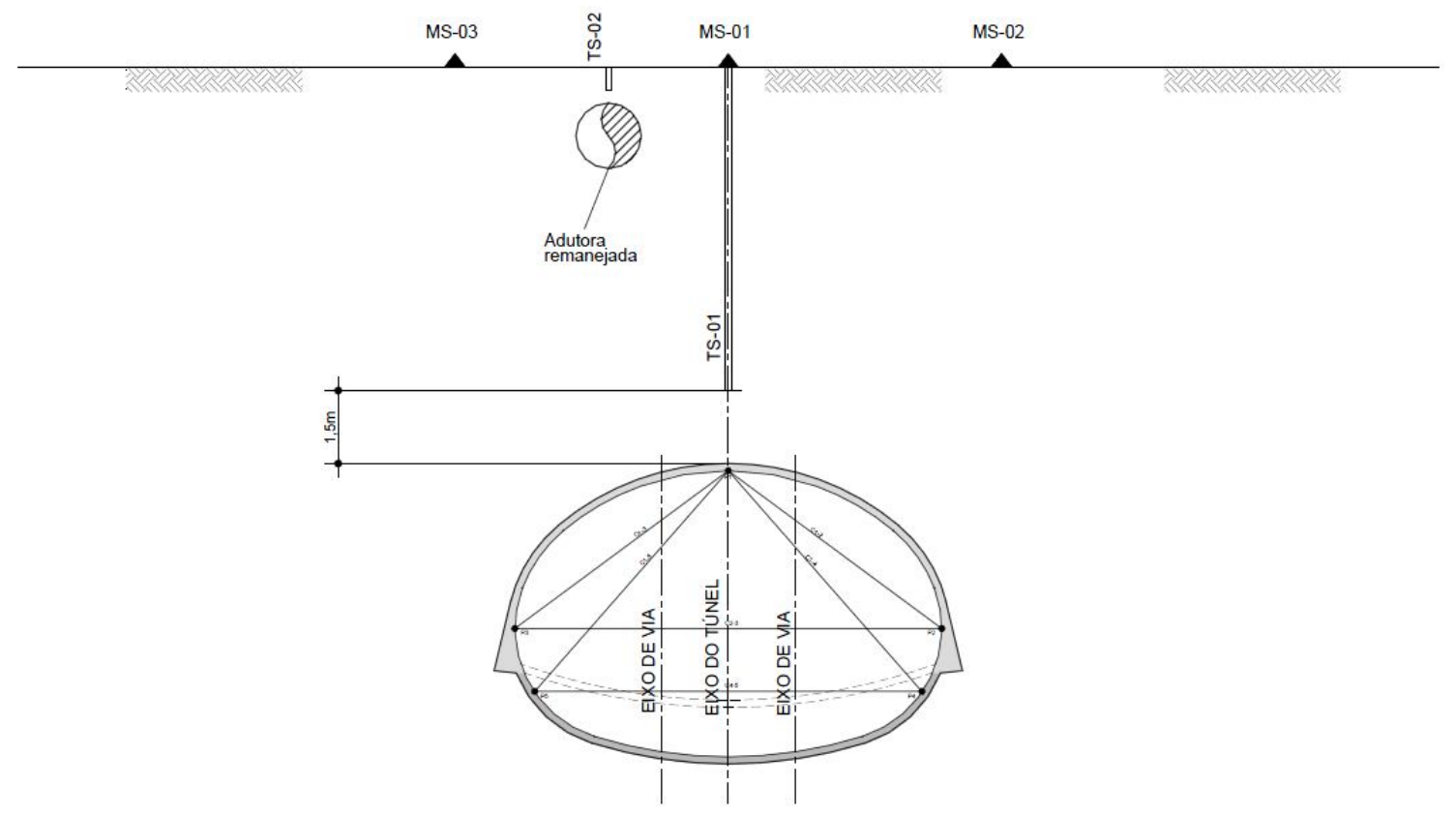

Figura 32 Seção típica de instrumentação do túnel de via - seção Tipo B

As edificações lindeiras localizadas dentro da área de influência da obra foram instrumentadas com o mínimo de três pinos de recalque, de forma a definir um plano. 
A frequência de leitura dos instrumentos foi especificada em projeto e adequada no decorrer da execução da obra, em função da distância da frente de escavação, do método construtivo e das condições geológica-geotécnicas do trecho.

$\mathrm{Na}$ Tabela 3 são apresentadas quantidades aproximadas dos instrumentos utilizados no túnel de via.

\begin{tabular}{|c|c|}
\hline Marcos superficiais & 160 \\
\hline Tassômetros & 120 \\
\hline Piezômetros & 27 \\
\hline Pinos em edificações & 250 \\
\hline $\begin{array}{c}\text { Seções de convergência e } \\
\text { nivelamento }\end{array}$ & 40 \\
\hline
\end{tabular}

Tabela 3 - Quantidades dos instrumentos utilizados no túnel de via 


\section{ANÁLISE TEÓRICA DA EXECUÇÃO DO SUPORTE}

O arco invertido (ou invert) pode trabalhar como fundação e como elemento de travamento lateral da casca. Como fundação, o invert tem a função de distribuir as cargas da casca para o maciço. Para tanto, o invert deverá ter forma, dimensionamento e detalhamento adequados. Como elemento de travamento, o invert proporciona uma componente de força sub-horizontal que equilibra os empuxos laterais.

Nos túneis em solo executados com concreto projetado, a fundação da calota limita a tensão de confinamento que esta aplica ao maciço. Havendo necessidade de dotar a calota de fundação eficaz, pode-se utilizar sapatas, arco invertido provisório ou definitivo - sempre o mais próximo possível junto à frente, ou ainda outros tipos de fundação. Como procedimento alternativo, pode-se parcializar à frente adotando-se túneis laterais (side-drifts). Em geral, o arco invertido provisório não apresenta forma adequada para distribuir as tensões para o maciço. Além do condicionante geométrico, deve ser considerada ainda sua distância em relação à frente, os parâmetros de rigidez e resistência do solo e o ciclo de escavação. Assim, a utilização de arco invertido provisório é eficiente apenas em condições específicas de geometria e de comportamento do maciço.

A distância entre o arco invertido construído e a frente de escavação pode ser calculada de diversas maneiras. Entretanto, deve ser considerado o efeito do lençol freático, a estratificação do maciço, o desconhecimento do próprio maciço e do comportamento de adutoras, galerias e outras interferências, que reduzem o efeito de arqueamento do solo junto à frente, solicitando, de maneira não prevista, a calota.

Em função do arco invertido provisório, não apresentar forma adequada para distribuir as tensões para o maciço, a junta entre a calota e o arco invertido provisório tem fundamental importância.

Com o intuito de basear tecnicamente o entendimento do comportamento da estrutura, faz-se necessário estudar alguns conceitos básicos da teoria das cascas e 
arqueamento das tensões do solo, os quais serão apresentados nos itens a seguir.

\subsection{Teoria das cascas}

Cascas são estruturas de superfície delgadas, não planas, que recebem cargas distribuídas e reagem por meio de esforços solicitantes predominantemente de tração e compressão. Quando a espessura da casca é pequena, comparando-se com as outras dimensões, a rigidez a momento fletor (que é proporcional ao momento de inércia) é muito pequena, e pode ser considerada nula. Nesses casos as cascas podem ser estudadas pela teoria da membrana, ou seja, as cargas externas serão absorvidas por meio de esforços solicitantes normais de compressão e tração.

Uma casca é um corpo tridimensional, sendo uma das suas dimensões muito menor do que as outras duas, e a curvatura da sua superfície média na configuração inicial não é nula.

Exemplos de cascas: reservatórios de pressão; asas de avião; tubos; exterior de foguetes; casca de ovo; lâmpada; pneus e revestimentos de túneis.

É importante notar que as forças de membrana, nas cascas de revolução, são independentes da flexão e são totalmente definidas pelas condições de equilíbrio estático. Na derivação da teoria de membrana as propriedades do material não são usadas, e, por isso, ela é válida para todas as cascas, independentemente do material utilizado.

Uma casca cilíndrica é formada por uma linha reta, a geratriz, que se desloca ao longo de uma trajetória fechada paralela.

Um elemento de uma casca cilíndrica está compreendido por duas geratrizes e dois planos normais ao eixo axial $\mathrm{x}$, distanciadas de $\mathrm{dx}$.

Esse elemento é posicionado pelas coordenadas $\times$ e $\theta$. 


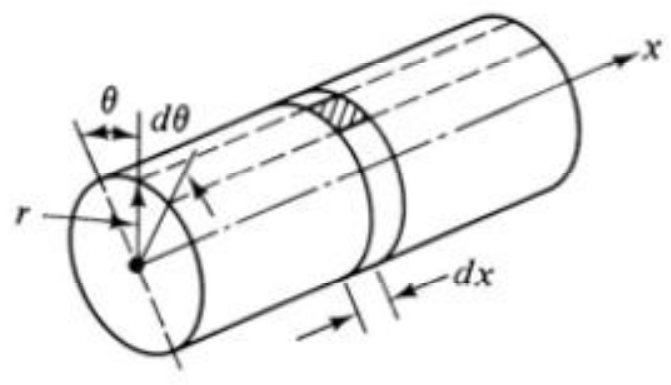

(a)

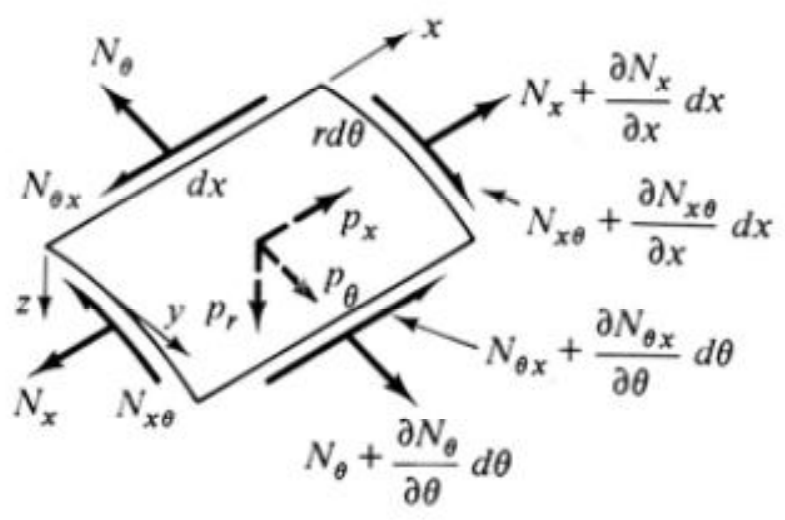

(b)

Figura 33 Casca cilíndrica posicionada pelas coordenadas x e $\theta$

Adota-se um carregamento que atua nesta casca cilíndrica.

Nesse caso, um corpo livre de um elemento da membrana contém as forças aplicadas (figura anterior).

As componentes em $x$ e $\theta$ das forças externas são $p_{x}$ e $p_{\theta}$, com sentido positivo no sentido positivo dos respectivos eixos.

A componente normal ou radial do carregamento, $\mathrm{p}_{\mathrm{r}}$, atua no sentido positivo para dentro.

O equilíbrio de forças nas direções $x, \theta$ e r são, respectivamente,

$$
\begin{gathered}
\frac{\partial N_{x}}{\partial x} d x r d \theta+\frac{\partial N_{x \theta}}{\partial \theta} d \theta d x+p_{x} d x r d \theta=0 \\
\frac{\partial N_{\theta}}{\partial \theta} d \theta d x+\frac{\partial N_{x \theta}}{\partial x} d x r d \theta+p_{\theta} d x r d \theta=0 \\
N_{\theta} d x d \theta+p_{r} d x r d \theta=0 .
\end{gathered}
$$

Dividindo essas expressões por $d x r d \theta$, obtêm-se as equações de equilíbrio para cascas cilíndricas. 
Assim,

$$
\begin{gathered}
N_{\theta}=-p_{r} r \\
\frac{\partial N_{x}}{\partial x}+\frac{1}{r} \frac{\partial N_{x \theta}}{\partial \theta}=-p_{x} \\
\frac{\partial N_{x \theta}}{\partial x}+\frac{1}{r} \frac{\partial N_{\theta}}{\partial \theta}=-p_{\theta} .
\end{gathered}
$$

Para um dado carregamento, $\mathrm{N}_{\theta}$ é obtida da primeira equação; $\mathrm{N}_{\mathrm{x} \theta}$ e $\mathrm{N}_{\mathrm{x}}$ são obtidas integrando as outras duas.

Para os estudos do comportamento da estrutura neste trabalho, a componente mais significativa é o $N_{\theta}$ dado pela equação $N_{\theta}=-p_{r} r$.

\subsection{Arqueamento das tensões do solo}

A escavação de um túnel em um maciço, previamente em equilíbrio, pode ser descrita como a remoção das tensões existentes no contorno da abertura. Em função disso, ocorre a reordenação do estado de tensões resultando em uma nova situação de equilíbrio. Sendo o maciço capaz de se autoportar após a escavação, não há necessidade de estrutura de suporte. Caso contrário, um revestimento rígido é requerido para suportar a condição escavada, contendo as deformações do maciço. O tempo decorrido entre a escavação e a execução do revestimento de suporte permite a redistribuição de tensões, em um fenômeno chamado arqueamento de tensões. $\mathrm{O}$ arqueamento das tensões depende das propriedades do maciço circundante e do processo construtivo adotado.

As deformações do maciço antes e após a execução do revestimento acarretam a redistribuição das tensões no maciço. Isso ocorre em detrimento da mobilização da resistência ao cisalhamento do maciço vizinho à escavação. Conforme detalhado por França (21), em sua dissertação de mestrado, esse fenômeno é entendido analisando o comportamento do maciço através de faixas de solo sobre a calota do túnel. Conforme ilustrado na Figura 34 (copiada de França (21)), faixas de solo A, B e C, antes da escavação, situam-se no perímetro da abertura; em função da escavação, a faixa de solo A tende a se deslocar para baixo, mais do que a faixa de 
solo $\mathrm{B}$, a qual, por sua vez tende a se deslocar mais do que a $\mathrm{C}$. Essas diferenças de deslocamento induzem tensões de cisalhamento entre as faixas de solo, resultando no arqueamento das tensões no maciço. Entende-se o efeito de arqueamento de tensões a partir da indução de tensões de cisalhamento pela diferença de deslocamentos promovida aos elementos da fronteira da escavação, admitindo como hipótese que, antes da escavação, as tensões principais no maciço são verticais e horizontais, com tensão de cisalhamento nula. O colapso ocorre quando o maciço não é capaz de resistir à tensão de cisalhamento.

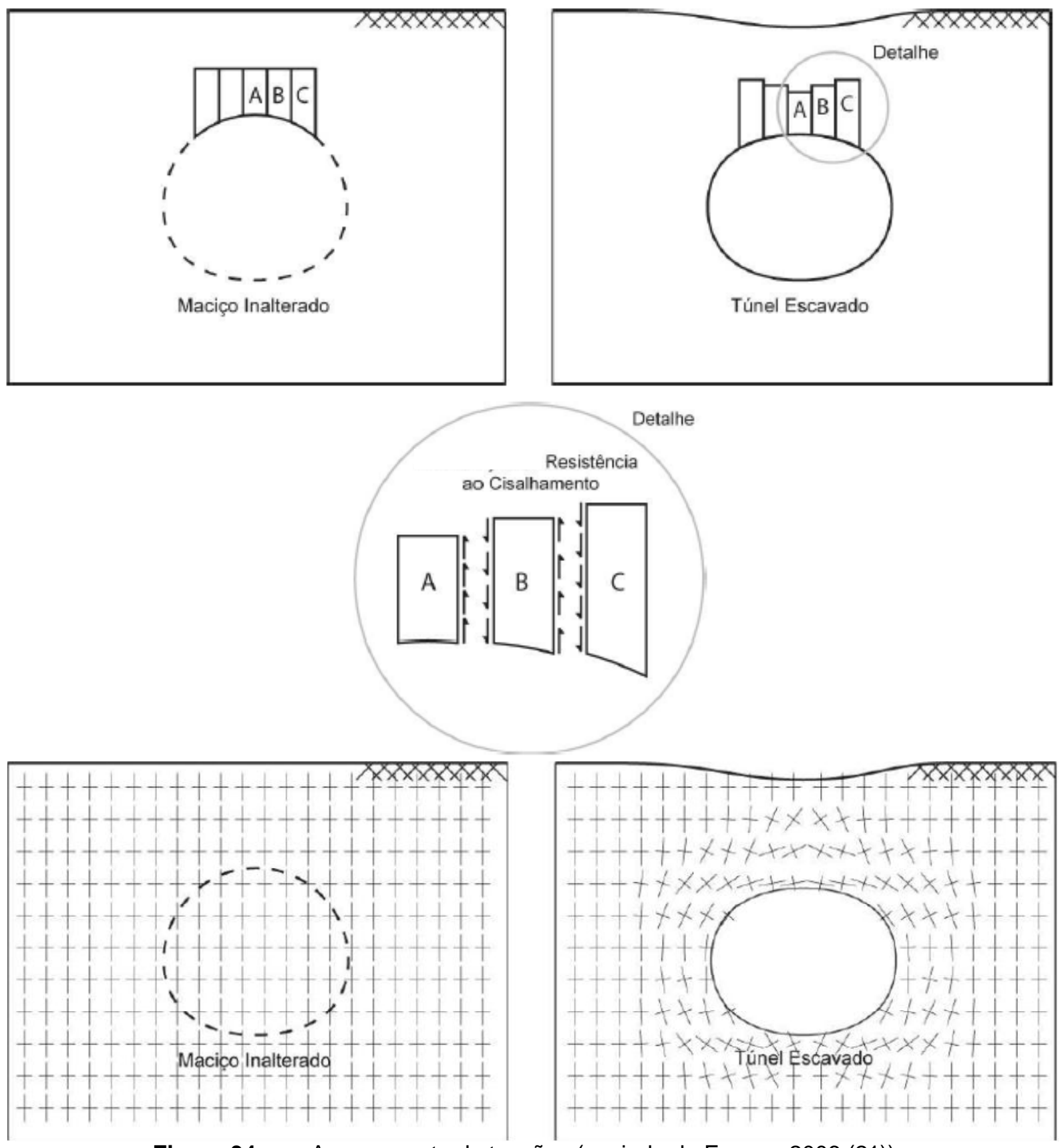

Figura 34 Arqueamento de tensões (copiado de França, 2006 (21)) 
O arqueamento do maciço depende, entre outros fatores, da rigidez geométrica e dos parâmetros de resistência do maciço nas imediações do túnel.

A reorganização das tensões ocorre tridimensionalmente, tanto nos planos transversais ao eixo do túnel, como no plano longitudinal, conforme pode-se observar na Figura 35 a seguir.
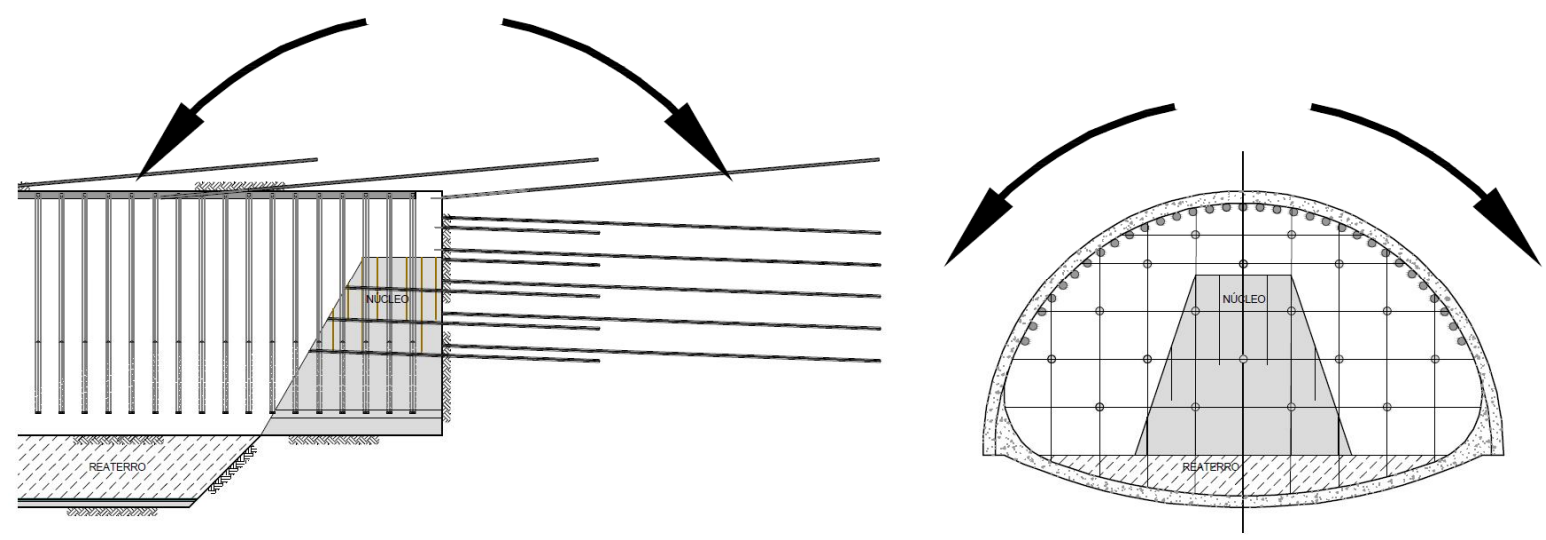

Figura 35 Efeito do arqueamento tridimensional (longitudinal e transversal)

Esse efeito tridimensional infere acréscimos de tensão em zonas à frente e atrás da escavação. Conclui-se que, com o avanço da escavação do túnel, há um acréscimo de tensão na zona à frente da escavação, região não escavada, e também acréscimos de tensão no revestimento do trecho já escavado, carregando o revestimento, gradativamente, até atingir a estabilização. As dimensões das regiões afetadas pela escavação dependem principalmente das características do maciço, mas também da geometria e método executivos do túnel. Segundo França (21), na maioria dos casos práticos, o efeito da escavação é sentido até, aproximadamente, dois diâmetros a montante e jusante da escavação. 


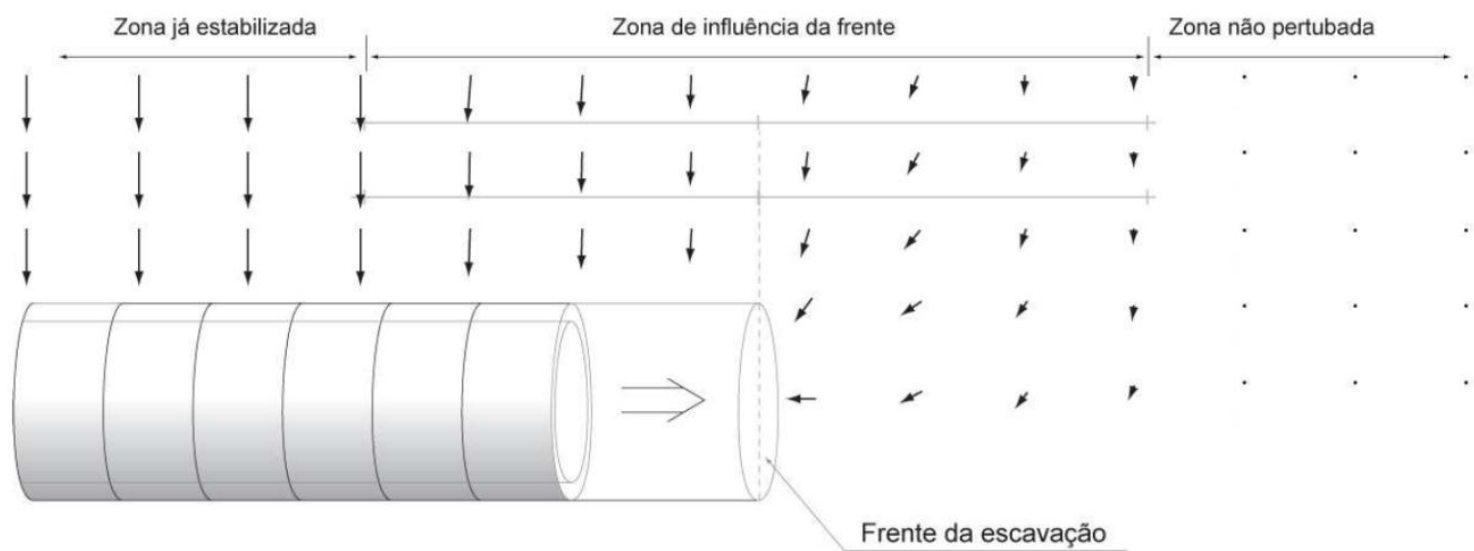

Figura 36 Efeitos no maciço resultantes da escavação do túnel (copiado de França (20))

A distribuição das tensões e deslocamentos verticais ao longo de uma linha longitudinal, situada no teto de um túnel, pode ser reproduzida conforme ilustrado na Figura 37. Conforme descrito pelos autores, a uma certa distância da frente de escavação, o maciço não sofre influência das tensões e deslocamentos decorrentes da escavação do túnel, representada pelo ponto "A". Aproximando-se da frente de escavação, no ponto "B", em razão do arqueamento longitudinal, há uma concentração de tensões verticais, a qual é seguida de um decréscimo acentuado até a frente, no ponto "C". No trecho representado pelos pontos "C" e "D", a camada de suporte ainda não foi executada, e, naturalmente, as tensões nesse trecho são nulas. Após a instalação da camada de suporte, ocorre novamente, um acréscimo de tensões verticais, em virtude do efeito de arqueamento longitudinal, representado pelo ponto "E", até que seja alcançada uma situação de equilíbrio, no ponto "F". Dependendo da rigidez relativa maciço-suporte e do comprimento sem a camada de suporte, pode haver uma concentração de tensões no ponto "E".

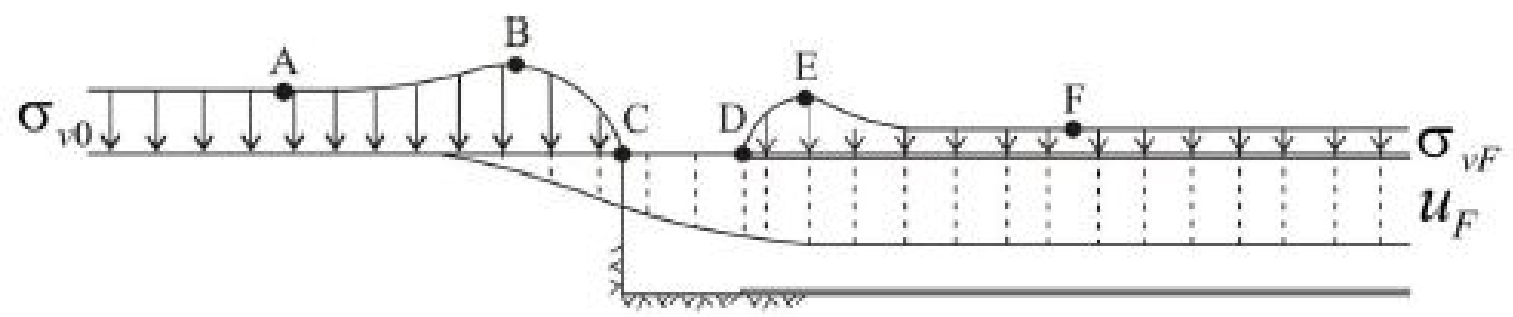

Figura 37 Distribuição das tensões e dos deslocamentos ao longo de uma linha longitudinal situada no teto do túnel (Eisenstein et al. (22)). 
Nos casos em que se utiliza o arco invertido provisório, faz-se necessária a demolição parcializada deste para execução do arco invertido definitivo. Nessa ocasião, a calota perde a fundação do trecho demolido, até que o revestimento do arco invertido definitivo obtenha resistência. Com essa perda de fundação, as tensões no revestimento transferem-se através de arqueamento das tensões no maciço e por bielas de compressão no revestimento. As tensões no revestimento são transferidas para frente da seção demolida, a qual ainda conta com o arco invertido provisório e, atrás, conta com o arco invertido definitivo, conforme ilustrado na Figura 38 a seguir. Essa redistribuição das tensões no maciço e no revestimento dependem da rigidez relativa maciço-suporte e características geométricas no túnel.

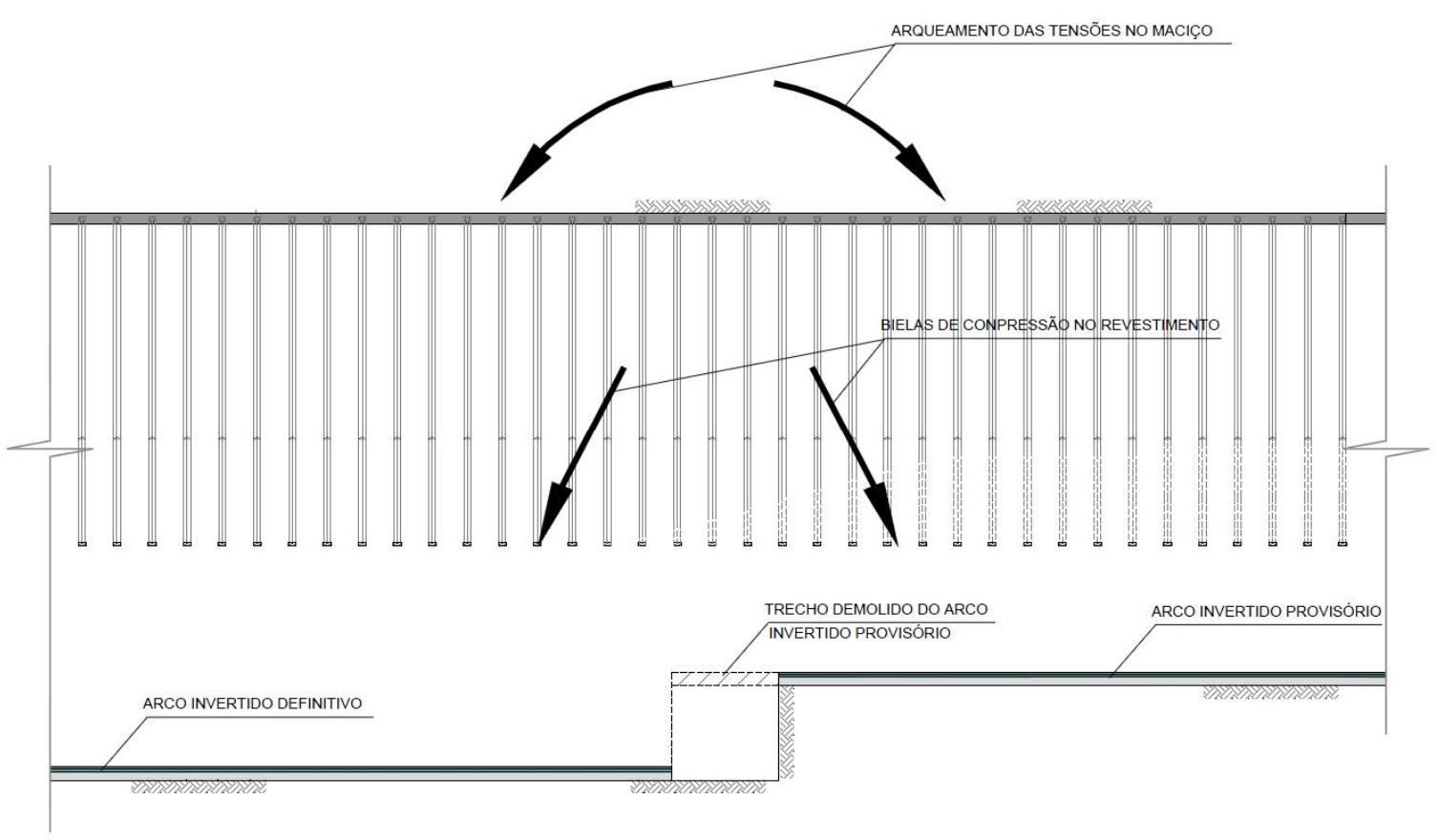

Figura 38 Distribuição das tensões no decorre da execução do arco invertido definitivo

\subsection{Caminhamento das cargas na estrutura}

De acordo com o exposto nos itens 4.1 e 4.2, pode-se estudar o provável caminhamento das cargas na estrutura do revestimento, no caso em análise. Em uma primeira etapa, na região do núcleo frontal, próximo à frente de escavação, as cargas do maciço são transferidas para o revestimento, de acordo com as premissas da teoria das cascas cilíndricas (representada pela força "N" na figura a seguir), e 
por sua vez, para o maciço sob a base da calota (representada pela reação "R", na Figura 39).
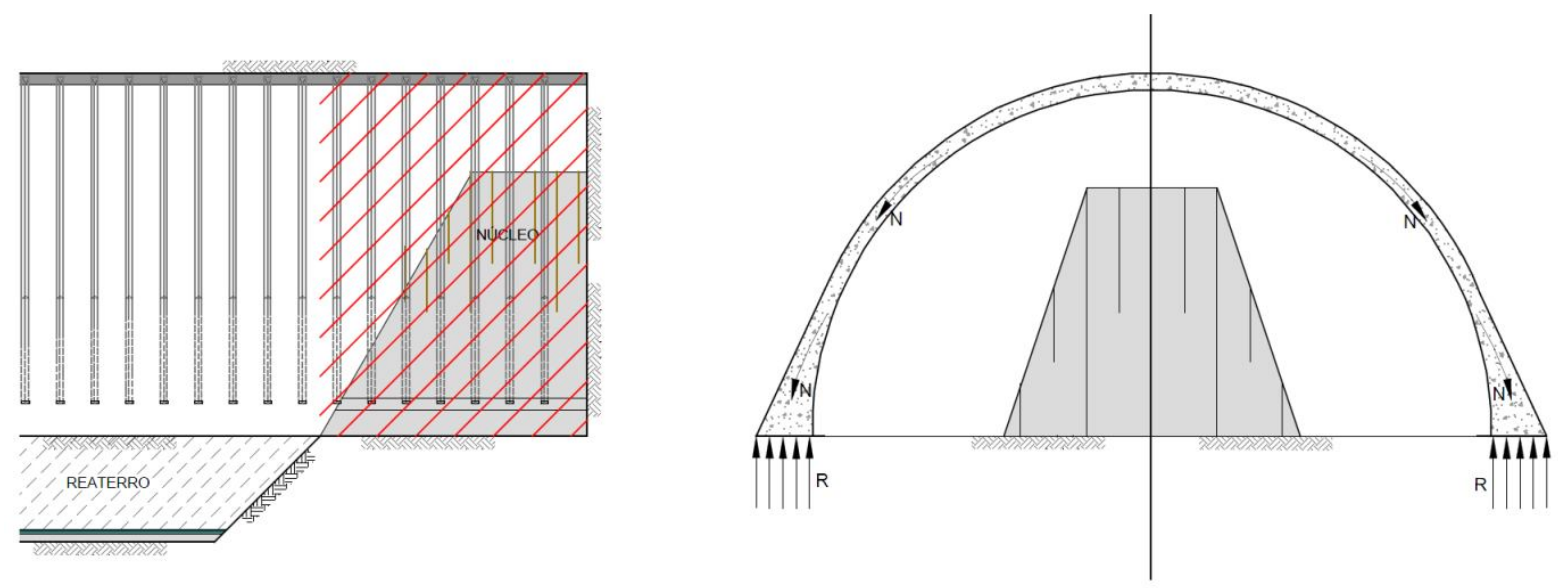

Figura 39 Cargas no revestimento na região do núcleo frontal

A tensão admissível do solo sob a base da calota deve levar em conta dois critérios que norteiam um projeto: o de segurança à ruptura e o de recalques admissíveis.

O critério de segurança à ruptura visa proteger de um colapso catastrófico a estrutura, sendo, normalmente, satisfeito mediante a aplicação de um coeficiente de segurança adequado à tensão, que causa a ruptura do solo. Nos casos em que a tensão na base da calota é maior do que a tensão admissível do solo podem-se utilizar diversas soluções para fundação da calota, como: execução do arco invertido, execução de fundação profunda (estacas raiz, entre outras).

É importante ressaltar, conforme detalhado no item anterior, que, em virtude do arqueamento das tensões no maciço, a carga no revestimento é introduzida gradativamente, em função da distância da frente de escavação.

Já o critério dos recalques faz parte da filosofia do método NATM, de monitoramento dos deslocamentos. É o critério que governa a maioria dos problemas práticos, sendo também o mais difícil de ser avaliado, em virtude da dificuldade na estimativa dos recalques a que estará sujeita a fundação. Os recalques podem ser controlados com a adoção de procedimentos executivos, como antecipação da execução do arco invertido, entre outros. 


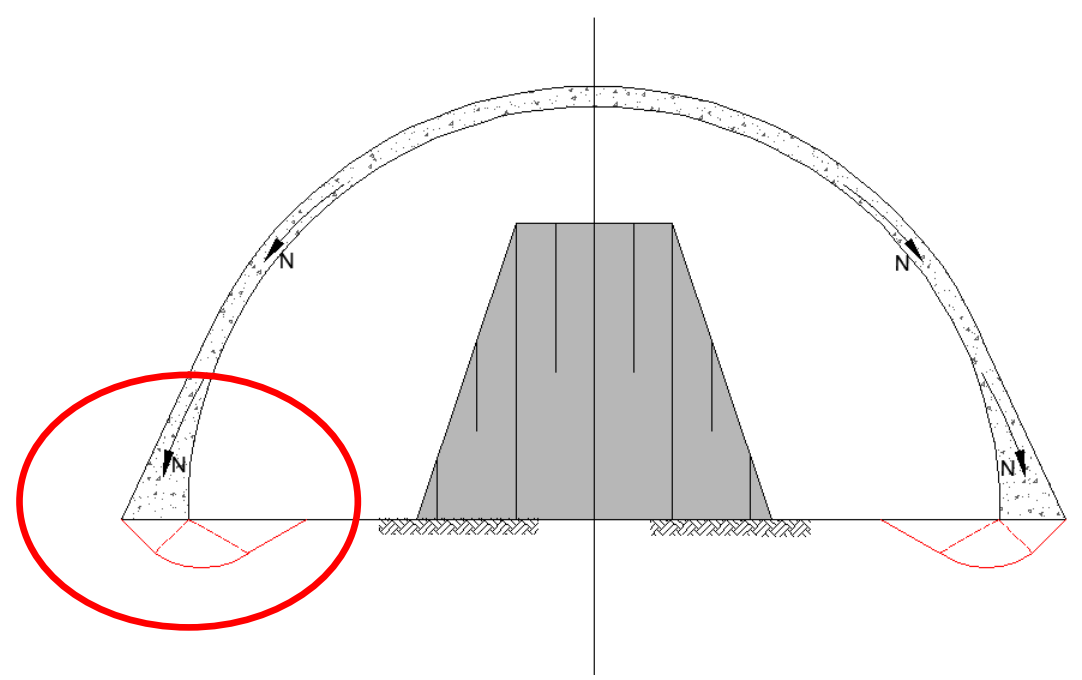

Figura 40 Tensão no solo sob a base da calota (efeito de punção do solo)

Em uma segunda etapa, a certa distância da frente de escavação, é executado o arco invertido provisório. Para tanto, faz-se necessária a escavação do maciço próximo as sapatas da calota, ocasionando a perda parcial ou total da fundação neste trecho. Com essa perda de fundação, as tensões no revestimento transferemse através de arqueamento das tensões no maciço e de bielas de compressão no revestimento à casca restante à frente da seção escavada, e ainda conta com o arco invertido atrás, conforme ilustrado na Figura 41.
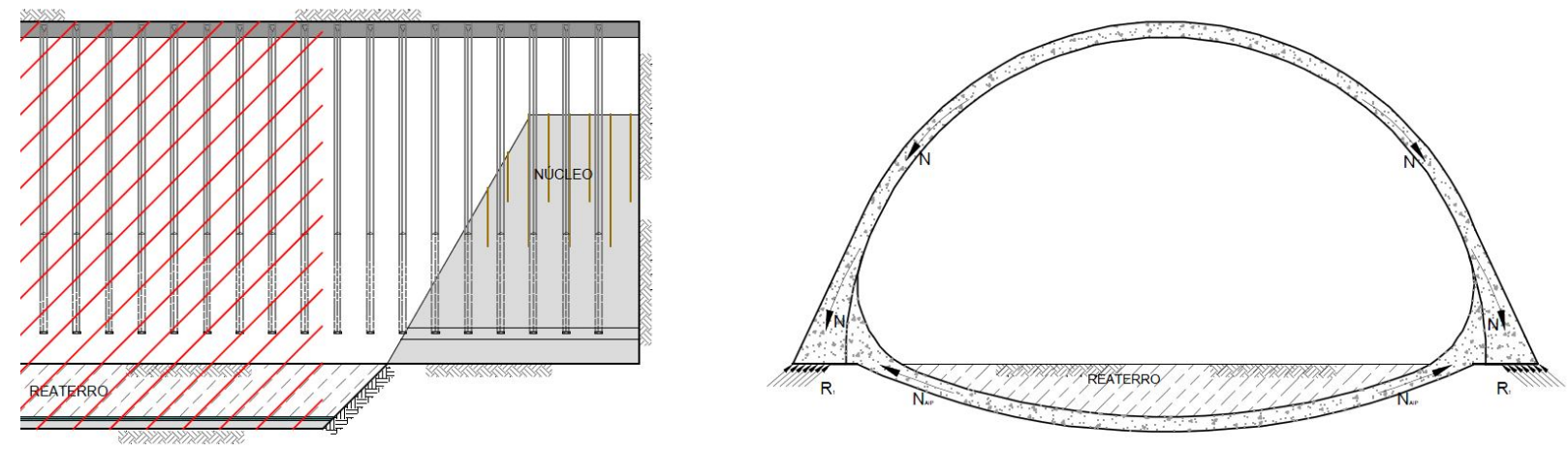

Figura 41 Cargas no revestimento com a execução do arco invertido

Com o prosseguimento das escavações do túnel e o ganho de resistência do material de revestimento do arco invertido, os esforços da calota vão sendo transferidos à estrutura do arco invertido gradativamente. $O$ modo em que essa 
transferência de esforços ocorre depende da geometria do túnel, características do maciço e do tipo de junta entre as duas estruturas. A transferência de esforços pode ocorrer em detrimento de forças normais, funcionando como uma treliça (equilíbrio de forças no nó), ou de forças de cisalhamento/flexão. Neste último caso, a armação do revestimento deve ser dimensionada para tal esforço.

Conforme detalhado por Kolymbas (23), em seu livro Tunnelling and Tunnel Mechanics, no estudo da ação das forças sobre o revestimento, a estrutura do túnel pode ser considerada como uma viga curva. Todos os cálculos referem-se a uma estrutura bidimensional com extensão de $1 \mathrm{~m}$, na direção longitudinal do túnel. Os esforços relevantes são:

p - forças distribuídas normais ao revestimento;

q - forças distribuídas tangenciais ao revestimento;

$\mathrm{N}$ - força normal;

$\mathrm{Q}$ - força transversal;

M - momento fletor;

Deve-se representar o comprimento do arco $s$ como funções. Se a forma da secção transversal do túnel é dada em coordenadas polares, x e $\theta$, os esforços acima mencionados podem também ser representados como funções de $\theta$. A partir das considerações de equilíbrio de um elemento de casca cilíndrica, com o comprimento $d_{x} \cdot$, onde $\dot{x}=\frac{d_{x}}{d_{\theta}}$, as relações que se seguem podem ser deduzidas de acordo com o exposto no item 4.1 .

$$
\begin{gathered}
\dot{Q}-N=-p r \\
\dot{N}+Q=-q r \\
\dot{M}=r Q
\end{gathered}
$$

Essa é a representação de um sistema de equações diferenciais. Os resultados são simplificados nos casos especiais, se aceitarmos que, em virtude da deformação, quando o concreto projetado ainda não está completamente endurecido, todos os momentos de flexão anulam-se, $M=0$, e que (consequentemente) não há cisalhamento significativo entre o maciço e o revestimento de concreto projetado, $q=$ 
o. Portanto, a partir das equações para as seções com curvatura constante da calota ( $r=$ constante, pode-se considerar $p=$ constante e $N=-p r=$ constante $)$.

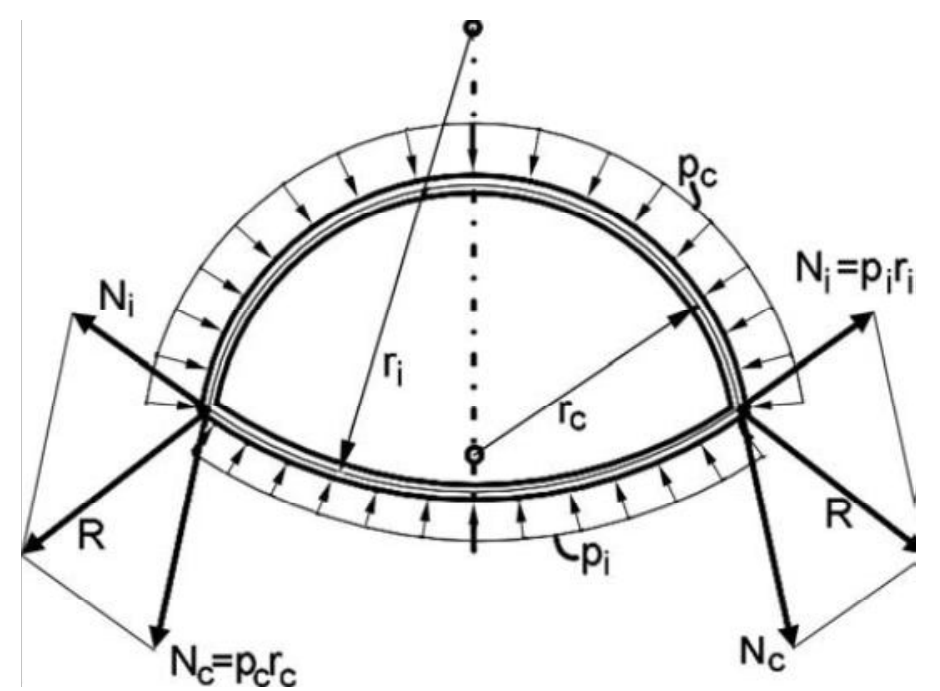

Figura 42 Forças na região das juntas entre a calota e o arco invertido (copiado de Dr. Kolymbas (23))

A força resultante $R$, representada na Figura 42, é exercida no maciço. Semelhantemente à primeira etapa, caso o maciço não seja competente para suportar a força resultante $\mathrm{R}$, devem-se adotar alternativas como: utilização de sapatas, alargando a base do revestimento da calota (os chamados pés de elefante), alteração da geometria do túnel ou utilização de fundação profunda, como estacas raiz.

Os valores das forças normais de compressão no revestimento da calota e arco invertido, $N c$ e $N i$, respectivamente, conforme ilustrado na figura anterior, devem ser verificadas com relação à tensão admissível de compressão no concreto projetado. Se $\beta$ é a resistência à compressão do concreto projetado, e $d_{c} e d_{i}$ as espessuras do revestimento de concreto projetado da calota e arco invertido, respectivamente, temse:

$$
\begin{aligned}
& d_{c}>\frac{N_{c}}{\beta}=\frac{p_{c} r_{c}}{\beta} \\
& d_{i}>\frac{N_{i}}{\beta}=\frac{p_{i} r_{i}}{\beta}
\end{aligned}
$$




\section{ANÁLISE NUMÉRICA DA EXECUÇÃO DO REVESTIMENTO PRIMÁRIO DO TÚNEL DO LOTE 1 DA LINHA 5 (LILÁS) DO METRÔ DE SÃO PAULO}

\subsection{Software utilizado na modelagem numérica}

De acordo com informações do manual do usuário (24), o Phase2 é um programa para análise bidimensional de tensões por elementos finitos em escavações subterrâneas ou a céu aberto, para maciços rochosos ou solos.

O maciço é modelado como meio contínuo e pode ser considerado como meio elástico ou elasto-plástico. O programa permite a inclusão de vários elementos, como: juntas, elementos de suporte (cabos, tirantes e revestimentos de concreto) e a incorporação de um lençol freático, para efeito de cálculo de pressões neutras.

Os modelos matemáticos para representar o comportamento do maciço incluem Mohr-Coulomb, Generalized Hoek-Brown e Cam-Clay. Nos meios elásticos as tensões induzidas são distribuídas pelo programa, de modo que cada elemento resistirá aos esforços atuantes, independentemente da sua resistência de pico. Já nos modelos plásticos, as tensões serão transferidas para os elementos vizinhos sempre que as forças atuantes forem superiores às resistências de pico.

A Figura 43(a) mostra um meio contínuo com as tensões e uma abertura no seu interior que pode representar, por exemplo, a escavação de um túnel. Na Figura 43(b), está representada uma malha típica para tal problema, com extensão limitada e composta de elementos triangulares de três pontos nodais (nós i, j e k). As condições de contorno estão aplicadas como forças de superfície e/ou deslocamentos prescritos nos limites externos e, finalmente, na Figura 43(c), temos um elemento individualizado, com seus respectivos componentes de forças e deslocamentos nodais. 

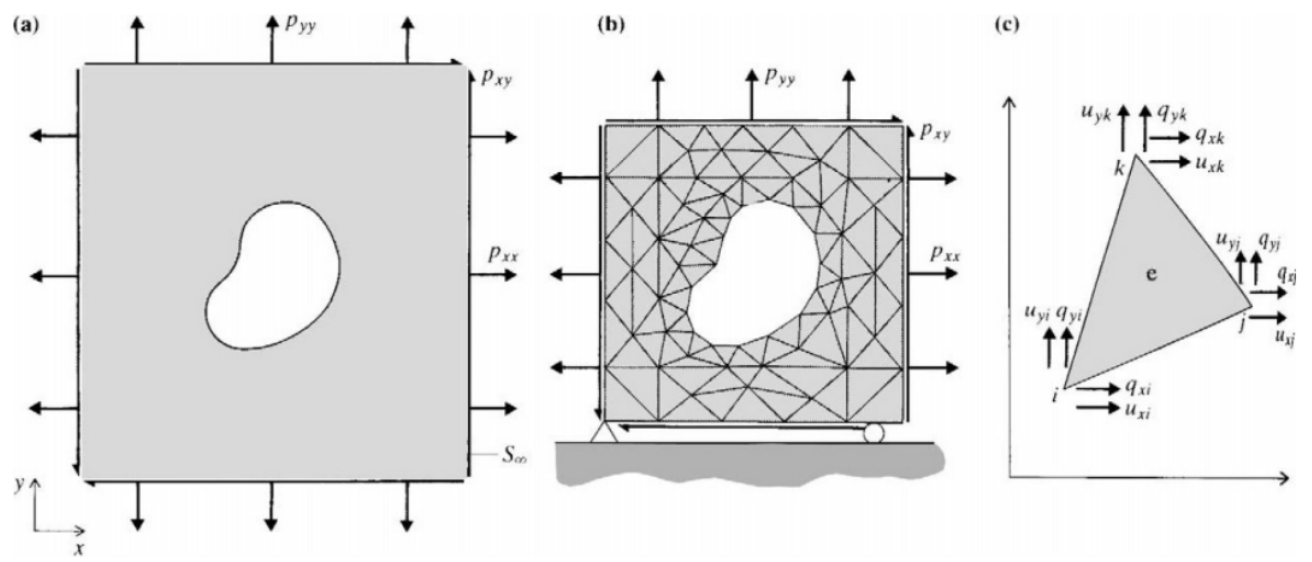

Figura 43 Elementos de um modelo de elementos finitos (Brady \& Brown (27))

Em que: $p_{x x}$, $p_{y y}$ e $p_{x y}$ são as tensões iniciais, $q_{x i}, q_{y i}, q_{x j}, q_{y j}, q_{x k}$ e $q_{y k}$ são as forças atuantes nos vértices dos triângulos e $u_{x i}, u_{y i}, u_{x j}, u_{y j}, u_{x k} e u_{y k}$ são os deslocamentos nodais.

Gerar a malha de elementos finitos automaticamente é uma das facilidades disponíveis no Phase2. Para isso, é necessário definir o tipo de elemento (triangular de 3 ou 6 nós ou quadrilateral de 4 ou 8 nós), tipo de malha (densidade dos elementos uniforme ou variável) e o número aproximado de nós que se deseja no entorno das escavações.

Outra funcionalidade importante do Phase2 é a simulação da escavação em múltiplos estágios. Essa ferramenta permite modelar cada etapa do método construtivo adotado.

O estado de tensão inicial pode ser definido como constante ou gravitacional. Neste último, os componentes variam com a profundidade conforme a estratigrafia utilizada.

$\mathrm{Na}$ definição dos contornos das aberturas, dos contatos litológicos e dos limites externos do modelo, é possível optar pela entrada de dados por coordenadas, via teclado do computador, ou importando arquivos de extensão dxf (drawing exchange file), arquivos originários de outros programas, como Autocad, Topograph etc. Nesse caso, é necessário um cuidado especial para que os objetos do modelo (escavações, contatos, limites externos etc.) sejam criados sempre em "layers" específicos, no sentido horário, e que não apresentem sobreposição de linhas.

$\mathrm{Na}$ sequência, é necessário definir as propriedades dos materiais: peso específico, Coeficiente de Poisson e Módulo de Young e os parâmetros de resistência. 
Posteriormente, seleciona-se também o tipo desejado para o comportamento dos materiais: elástico ou elasto-plástico.

Os resultados podem ser visualizados por meio gráfico, em termos de: tensões principais, tensões efetivas, tensões de cisalhamento, deslocamentos, vetores de tensões principais, configuração deformada, elementos plastificados e outros.

\subsection{MODELO CONSTITUTIVO}

Os modelos constitutivos elásticos e elasto-plásticos possuem condições de representar com razoável qualidade o comportamento real dos solos. Pode-se dizer que os modelos mais comumente utilizados para estudo de problemas de geotecnia são: Tresca, Von Mises, Mohr- Coulomb, Drucker-Prager e Cam Clay.

É sabido no meio técnico, e foi documentado na dissertação de Metrado de Machado (28), que o critério de ruptura de Mohr-Coloumb representa de forma satisfatória os deslocamentos induzidos por escavação de túneis, associado à plasticidade perfeita.

Como a finalidade deste item é modelar numericamente o comportamento da escavação do túnel da Linha 5 - Lote 1 do Metrô de São Paulo, para posteriormente comparar com os dados da instrumentação da obra, adotar-se-á o critério de ruptura de Mohr-Coulomb nas modelagens numéricas que se seguem.

\subsubsection{Critério de ruptura de Mohr-Coulomb}

Critérios de ruptura são formulações que procuram refletir as condições em que ocorre a ruptura dos materiais. A análise do estado de tensões que provoca a ruptura é o estado da resistência ao cisalhamento dos solos. Segundo Pinto (29), os critérios de ruptura que melhor representam o comportamento dos solos são os de Coulomb e de Mohr.

Define-se como resistência ao cisalhamento do solo a tensão cisalhante que ocorre no plano de ruptura, no instante da ruptura. Esta é caracterizada pela formação de uma superfície de cisalhamento contínua na massa de solo. Existe, portanto, uma camada de solo em torno da superfície de cisalhamento que perde suas características durante o processo de ruptura, formando assim a zona cisalhada. 
O critério de Coulomb pode ser expresso como: "não há ruptura se a tensão de cisalhamento não ultrapassar um valor dado pela expressão $c+f \sigma$ sendo $c$ e $f$ constantes do material e $\sigma$ a tensão normal existente no plano de cisalhamento". Os parâmetros c e f são denominados, respectivamente, coesão e coeficiente de atrito interno, podendo este ser expresso como tangente de um ângulo, denominado ângulo de atrito interno $\phi$. O critério de Mohr pode ser expresso como: "não há ruptura quando o círculo representativo do estado de tensões se encontrar no interior de uma curva, que é a envoltória dos círculos relativos a estados de ruptura, observados experimentalmente para o material'. Fazendo-se uma reta como envoltória de Mohr, seu critério de resistência fica análogo ao de Coulomb, justificando a expressão critério de Mohr-Coulomb, costumeiramente empregada na Mecânica dos Solos (Pinto, (29)). A Figura 44 ilustra a definição dos parâmetros de resistência dos critérios.
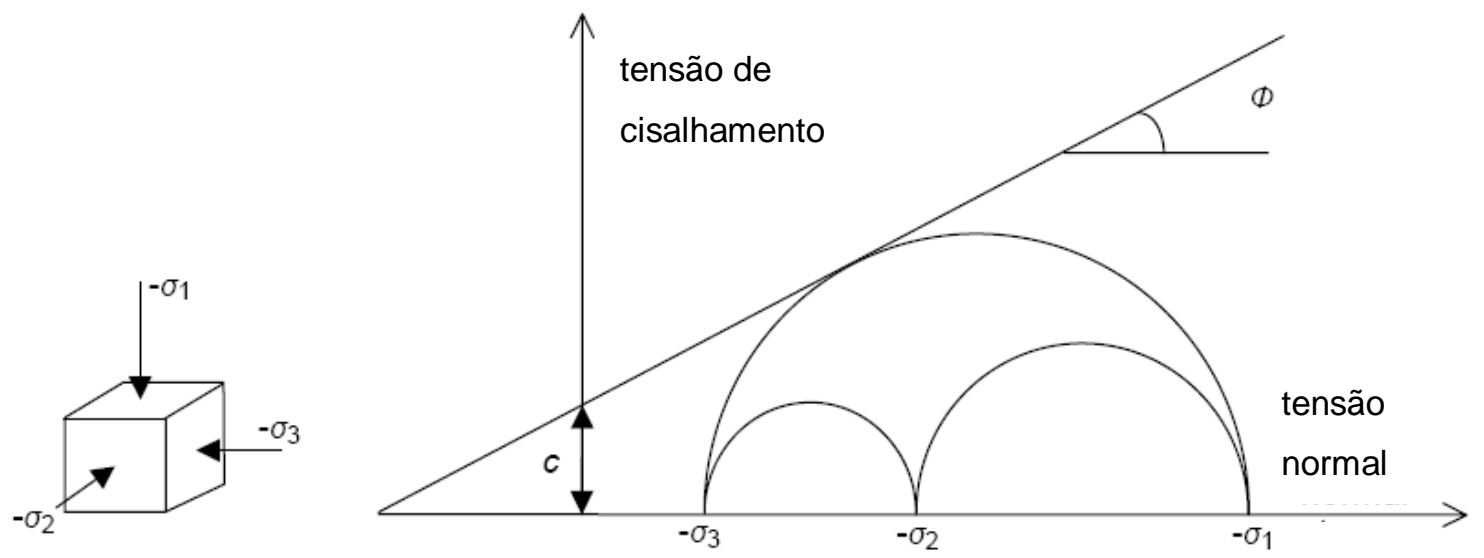

Figura 44 Definição dos parâmetros de resistência

Os dois parâmetros do material c e f podem ser determinados a partir de ensaios de compressão triaxial convencional levando o material até a condição de ruptura.

$\mathrm{Na}$ atualidade, o modelo Mohr-Coulomb é o modelo constitutivo mais utilizado para análise de problemas de geotecnia.

A linha reta que determina a ruptura no critério de Mohr Coulomb é dada por:

$$
\tau_{f}=c^{\prime}+\sigma_{n f}^{\prime} * \tan \emptyset^{\prime}
$$

em que $\tau_{f}$ e $\sigma_{\text {nf }}$ são, respectivamente, a tensão efetiva de cisalhamento e a tensão 
efetiva normal no plano de ruptura, c' é a coesão e $\phi$, o ângulo de atrito interno, parâmetros do material já apresentados. A ruptura ocorre neste plano como resultado de uma combinação de efeitos. No plano de $\tau_{m a ́ x}$, apesar de a tensão cisalhante ser maior do que $\tau_{f}$, a tensão normal, atuante neste plano, também é superior à $\sigma_{\mathrm{nf}}$, garantindo a estabilidade nessa direção. Em outras palavras, a tensão máxima de cisalhamento não define a ruptura, e sim uma combinação de tensões ( $\tau$ e $\sigma)$.

Reescrevendo a equação em termos de tensões principais, obtém-se a expressão abaixo, que é utilizada como função de plastificação no modelo Mohr-Coulomb:

$$
\begin{gathered}
\sigma_{1}^{\prime}-\sigma_{3}^{\prime}=2 c^{\prime} \cos \emptyset^{\prime}+\left(\sigma_{1}^{\prime}-\sigma_{3}^{\prime}\right) \sin \emptyset^{\prime} \\
F=\sigma_{1}^{\prime}-\sigma_{3}^{\prime}-2 c^{\prime} \cos \emptyset^{\prime}-\left(\sigma_{1}^{\prime}-\sigma_{3}^{\prime}\right) \sin \emptyset^{\prime} .
\end{gathered}
$$

O critério de Mohr-Coulomb também pode ser expresso por meio dos invariantes $J_{1}, J_{2 D}$ e $\theta$ (conforme exposto por, Juan Pablo Ibañez (30)):

$$
\begin{gathered}
\theta=\tan ^{-1}\left[\frac{1}{\sqrt{3}} \frac{2 \sigma_{2}-\sigma_{1}-\sigma_{3}}{\sigma_{1}-\sigma_{3}}\right] \\
F=\sqrt{J_{2 D}}-\left(\frac{c}{\tan \varnothing}+\frac{J_{1}}{3}\right) g(\theta)=0
\end{gathered}
$$

Em que:

$$
\begin{gathered}
g(\theta)=\frac{\operatorname{sen} \emptyset}{\cos \theta+(\operatorname{sen} \theta \operatorname{sen} \varnothing) / \sqrt{3}} \\
J_{1}=3 * T_{m} \\
J_{2 D}=\frac{1}{3} \sigma_{0}^{2}
\end{gathered}
$$

sendo $T_{m}$ a tensão hidrostática e $\sigma_{0}$ a tensão de escoamento determinada experimentalmente.

A função de plastificação representa, no estado geral das tensões, um cone hexagonal irregular, conforme ilustrado na Figura 45. Como o comportamento é do tipo elasto-plástico perfeito, usa-se como constantes os parâmetros c' e f', independente das deformações plásticas que estiverem ocorrendo. 


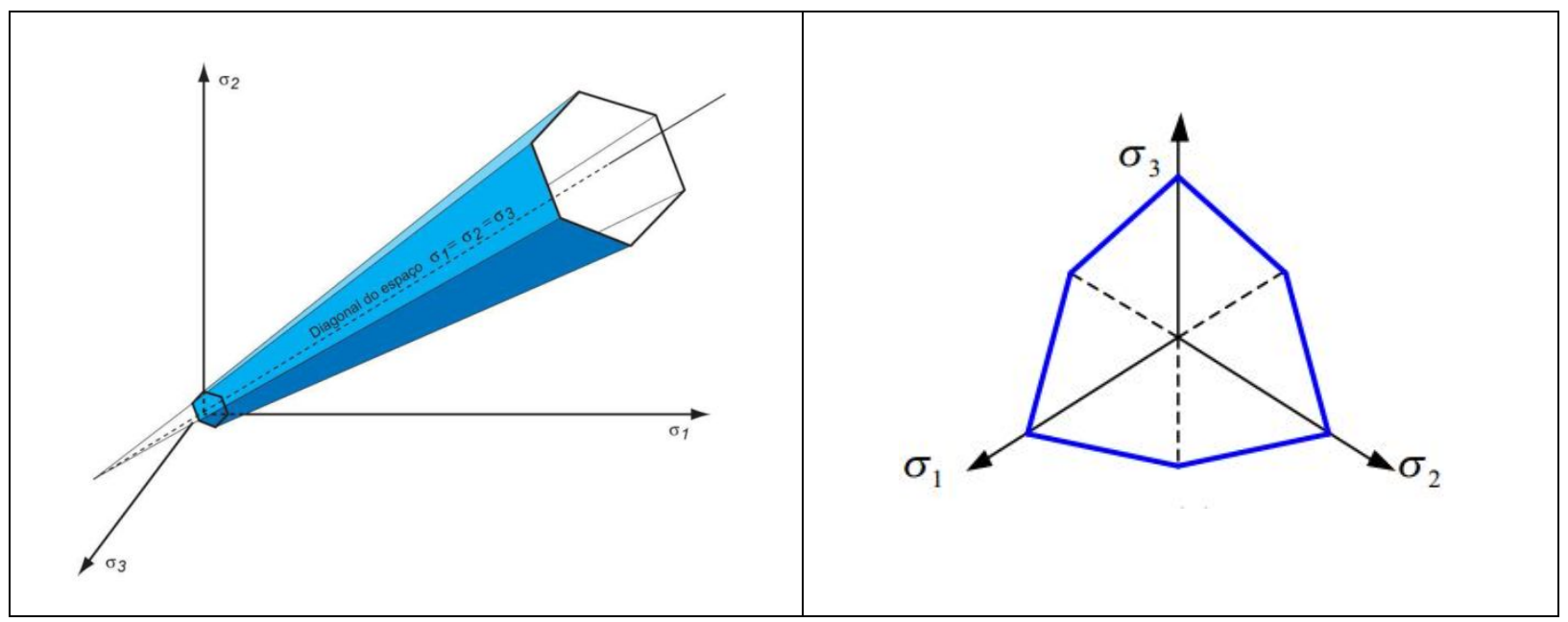

Figura 45 Superfície de plastificação de Mohr-Coulomb

Trata-se de um modelo elasto-plástico perfeito, cujo comportamento elástico é isotrópico e controlado pelo Módulo de Elasticidade (E') e pelo coeficiente de Poisson $\left(v^{\prime}\right)$.

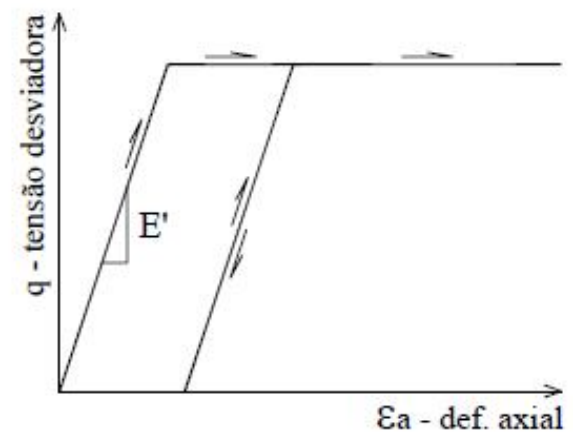

(a) curva tensão-deformação
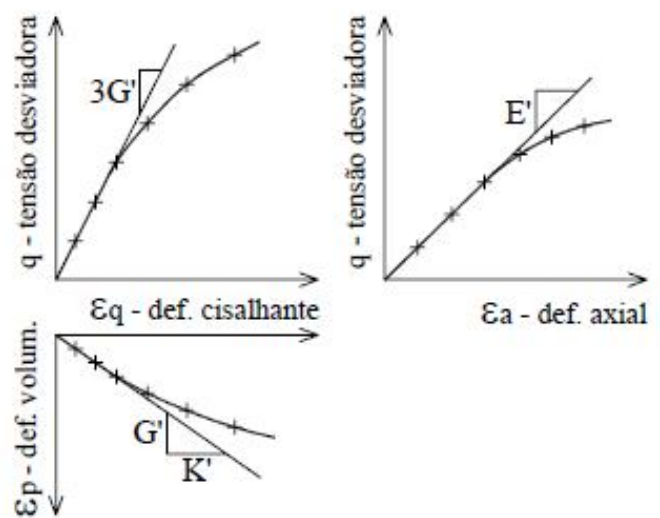

(b) obtenção dos parâmetros elásticos

Figura 46 Curvas tensão-deformação do modelo Mohr-Coulomb

A deformação elástica total pode ser dividida em deformação cisalhante $\left(\varepsilon_{q}\right)$, responsável apenas pela mudança de forma, e deformação volumétrica $\left(\varepsilon_{p}\right)$, responsável apenas pela mudança de volume, de maneira que cada parcela possa se correlacionar com as tensões através do Módulo Cisalhante (G') e do Módulo Volumétrico (K'), por meio de:

$$
\begin{aligned}
& \Delta q=3 G^{\prime} . \Delta \varepsilon_{q} \\
& \Delta p^{\prime}=K^{\prime} . \Delta \varepsilon_{p} \\
& \Delta \varepsilon_{p}=\frac{G^{\prime}}{K^{\prime}} \cdot \Delta \varepsilon_{q}
\end{aligned}
$$


Os módulos cisalhante e volumétrico podem ser obtidos por meio de ensaios triaxiais drenados, como mostrado na Figura 46(b), e se correlacionam com o módulo de elasticidade e coeficiente de Poisson por:

$$
\begin{aligned}
G^{\prime} & =\frac{E^{\prime}}{2\left(1+v^{\prime}\right)} \\
K^{\prime} & =\frac{E^{\prime}}{3\left(1-2 v^{\prime}\right)}
\end{aligned}
$$

A lei de fluxo, a relação entre a tensão e o incremento de deformação plástica, durante ocorrência de fluxo plástico, são definidos por meio da função potencial plástico. Caso o potencial plástico $(\mathrm{Q})$ coincida com a superfície de escoamento $F$, a lei de fluxo é dita associada; caso contrário, é chamada de não associada. O potencial plástico (Q) é a função dependente do tensor de tensões do material, cujo gradiente determina a direção dos acréscimos de deformação plástica.

Assim como nos modelos de Tresca e de von Mises, pode ser adotado fluxo associado para o modelo Mohr-Coulomb, $Q\left(\sigma_{i j}\right)=F\left(\sigma_{i j}\right)$. Dessa forma, o vetor de incremento de tensão é inclinado de acordo com o ângulo f ${ }^{\prime}$ e indica deformação volumétrica negativa, que significa dilatância (aumento do volume) do material quando sujeito a plastificação. Os solos podem experimentar aumento de volume na plastificação, mas o valor previsto pelo modelo de Mohr-Coulomb quando se adota fluxo associado é muito maior do que o observado na realidade. Outro problema apresentado pelo modelo quando se adota fluxo associado, é que ele prevê dilatância constante, quando, na realidade, os solos apresentam dilatância no início da plastificação e depois se deformam com volume constante.

Uma maneira de corrigir as falhas referidas acima é adotar fluxo não associado para o modelo, substituindo-se o ângulo de atrito $\phi$ pelo ângulo de dilatância $\mu$. O ângulo de dilatância $\mu$ expressa a relação existente entre os incrementos de deformação plástica volumétrica $d \varepsilon_{v}^{p}$ de e de deformação plástica cisalhante $d \gamma^{p}$, ou seja:

$$
\mu=\operatorname{sen}^{-1}\left(\frac{d \varepsilon_{v}^{p}}{d \gamma_{\text {máx }}^{p}}\right)=\operatorname{sen}^{-1}\left(\frac{d \varepsilon_{1}^{p}+d \varepsilon_{3}^{p}}{d \varepsilon_{1}^{p}-d \varepsilon_{3}^{p}}\right)
$$

Portanto, o potencial plástico $\mathrm{Q}\left(\sigma_{\mathrm{ij}}\right)$ é matematicamente semelhante à função do escoamento $F\left(\sigma_{i j}\right)$, podendo ser escrita como: 


$$
\begin{aligned}
& Q=\sqrt{J_{2 D}}-\left(a_{p p}+\frac{J_{1}}{3}\right) g_{p p}(\theta)=0 \\
& g_{p p}(\theta)=\frac{\operatorname{sen} \mu}{\cos \mu+(\operatorname{sen} \theta \operatorname{sen} \mu) / \sqrt{3})}
\end{aligned}
$$

em que $p p$ indica que o ponto pertence à função potencial plástico $Q$. A função $Q\left(\sigma_{i j}\right)$ deve passar pelo estado atual de tensão $P$ (Figura 47), que também pertence à função de escoamento $F\left(\sigma_{i j}\right)$, ou seja, $Q\left(\sigma_{i j}\right)_{p}=f\left(\sigma_{i j}\right)_{p}$,. Dessa condição, é possível determinar o valor de $a_{p p}$, por meio de:

$$
a_{p p}=\left[\frac{c}{\tan \varphi}+\left(\frac{J_{1}}{3}\right)_{p}\right] \frac{g(\theta)_{p}}{g_{p p}(\theta)_{p}}-\left(\frac{J_{1}}{3}\right)_{p}
$$
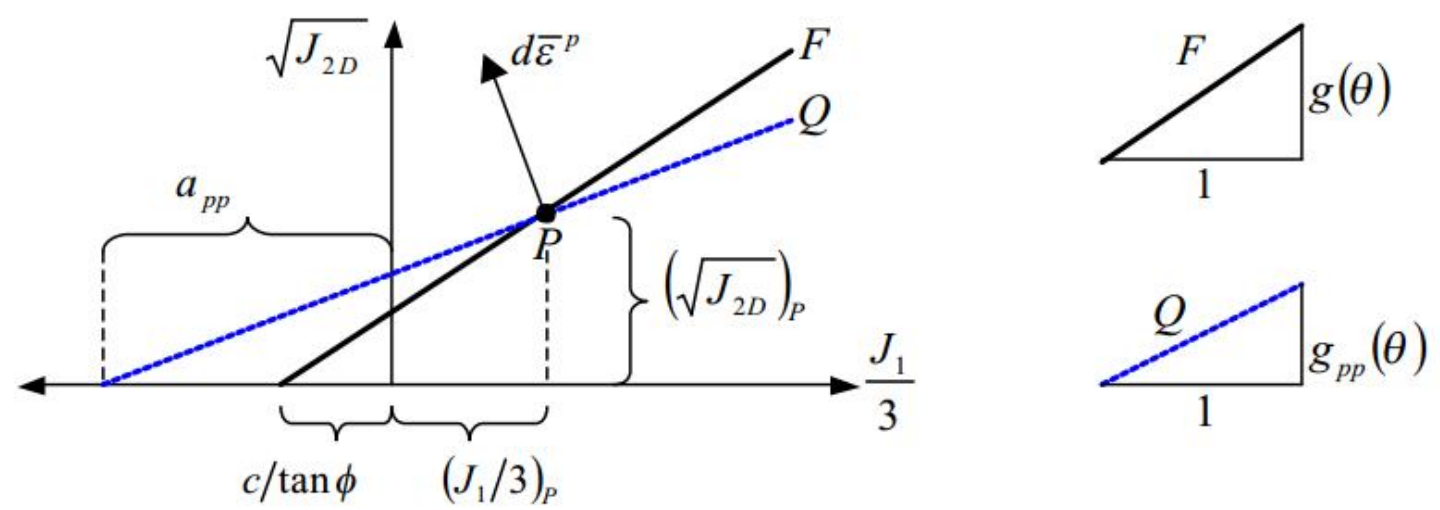

Figura 47 Modelo de Mohr-Coulomb com fluxo não associado, incluindo a função de potencial plástico Q (copiado de Juan Pablo lbañez (30))

A função $F$ é considerada fixa no espaço de tensões $\left(J_{1}, J_{2 D}, \theta\right)$, enquanto que a função $Q$ movimenta-se para passar através do ponto $P$. Assim, com o parâmetro adicional $\mu$ pode-se ajustar o modelo ao comportamento real do solo $\mu=\phi$ para lei de fluxo associada, $\mu<\phi$ para fluxo não associado com dilatância reduzida e $\mu=0$ para o material perfeitamente plástico, não dilatante $\left(d \varepsilon_{v}^{p}=0\right)$.

Esse procedimento tem a limitação do valor de $\mu$ ser utilizado como uma constante, o que implica na suposição de que o solo em fluxo plástico vai experimentar continuamente expansão volumétrica, independentemente do nível de cisalhamento a que está submetido. Isso não se verifica no caso real de solos, para os quais grandes deformações plásticas ocorrem sob volume constante (teoria do estado crítico). Uma modificação adicional do modelo seria, portanto, a definição do ângulo 
de dilatância $\mu$ como função dos incrementos de deformação plástica.

A formulação do modelo de Mohr-Coulomb pode ser aperfeiçoada para incluir a representação dos fenômenos de endurecimento (hardening) e amolecimento (softening) plásticos permitindo-se que os valores dos parâmetros c e $\varphi$ possam variar com a deformação plástica de desvio acumulada $E^{p}$.

Igualmente, se considerar que o ângulo de dilatância $\mu$ acompanha a evolução de $\varphi$ durante o cisalhamento, é dizer, $\mu\left(E^{p}\right)=\psi \phi\left(E^{p}\right)$, sendo $\psi$ uma constante.

A variação de c e $\phi$ durante o cisalhamento pode ser esquematizada em três zonas, indicadas na Figura 48 e descritas a seguir.
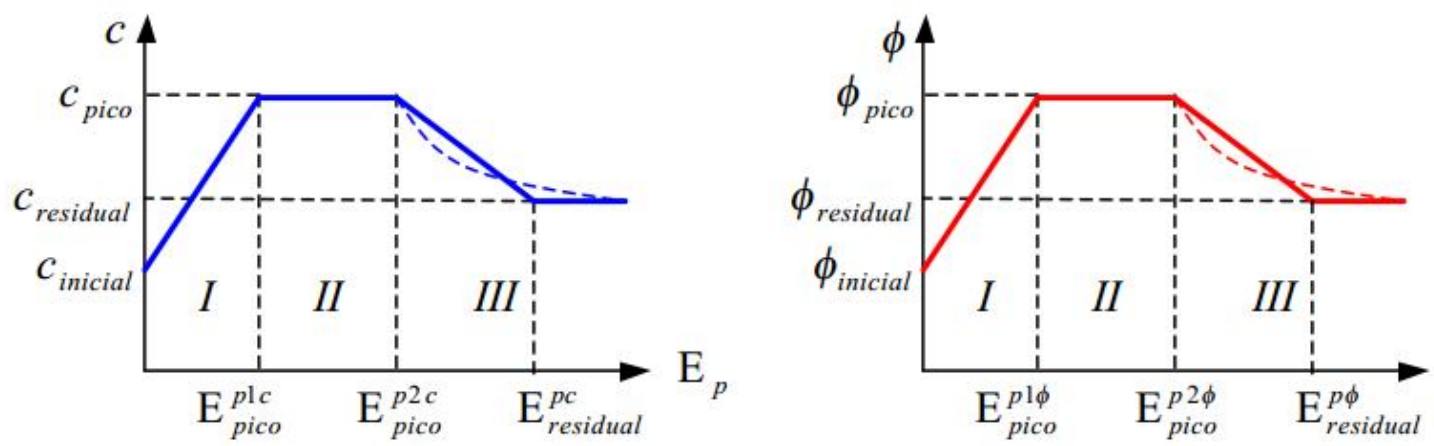

Figura 48 Evolução dos parâmetros c e $\phi$ com a deformação plástica de desvio acumulada (copiado de Juan Pablo Ibañez (30))

Zona I - endurecimento, em que c e $\phi$ crescem linearmente dos valores iniciais $c_{i}$ e $F_{i}$ até os valores de pico $c_{\text {pico }}$ e $\phi$ pico:

$$
\begin{gathered}
c=c_{\text {inicial }}+\frac{E^{p}}{E_{\text {pico }}^{p}}\left(c_{\text {pico }}-c_{\text {inicial }}\right) \\
\varnothing=\emptyset_{\text {inicial }}+\frac{E^{p}}{E_{\text {pico }}^{p}}\left(\emptyset_{\text {pico }}-\emptyset_{\text {inicial }}\right)
\end{gathered}
$$

Zona II - perfeitamente plástica, os parâmetros permanecem com seus valores de pico $\mathrm{c}_{\text {pico }}$ e $\phi$ pico.

Zona III - amolecimento, parâmetros de resistência decrescem gradualmente para valores residuais, linear ou exponencialmente. 


$$
\begin{gathered}
c=c_{\text {pico }}+\frac{E^{p}-E_{\text {pico }}^{p}}{E_{\text {residial }}^{p}-E_{\text {pico }}^{p}}\left(c_{\text {pico }}-c_{\text {residual }}\right) \\
\varnothing=\emptyset_{\text {pico }}+\frac{E^{p}-E_{\text {pico }}^{p}}{E_{\text {residial }}^{p}-E_{\text {pico }}^{p}}\left(\emptyset_{\text {pico }}-\emptyset_{\text {residual }}\right) \\
c=c_{\text {pico }}-\left(c_{\text {pico }}-c_{\text {residual }}\right)\left[1-e^{-a_{c}\left(E^{p}-E_{\text {pico }}^{p}\right)}\right] \\
\varnothing=\emptyset_{\text {pico }}-\left(\emptyset_{\text {pico }}-\emptyset_{\text {residual }}\right)\left[1-e^{-a_{\emptyset}\left(E^{p}-E_{\text {pico }}^{p}\right)}\right]
\end{gathered}
$$

\subsection{Modelo Computacional}

A modelagem numérica neste trabalho é utilizada para simular escavação do túnel, com ênfase nos deslocamentos. Nas modelagens consideram-se as fases da metodologia construtiva, incluindo a parcialização da escavação por meio da utilização de arco invertido provisório (AIP).

A geometria da seção transversal do túnel e a geologia local são as mesmas utilizadas no projeto executivo e documentadas no capítulo 3 deste trabalho.

Em razão da heterogeneidade do maciço ao longo do túnel, adotam-se três cenários geológicos distintos para simular os deslocamentos no decorrer da escavação do túnel. O primeiro cenário representa o trecho de túnel compreendido entre o Largo 13 de Maio e o túnel de ligação; o segundo cenário, entre o túnel de ligação e a Estação Adolfo Pinheiro e o terceiro e último cenário, entre a Estação Adolfo Pinheiro e a Praça Santa Cruz.

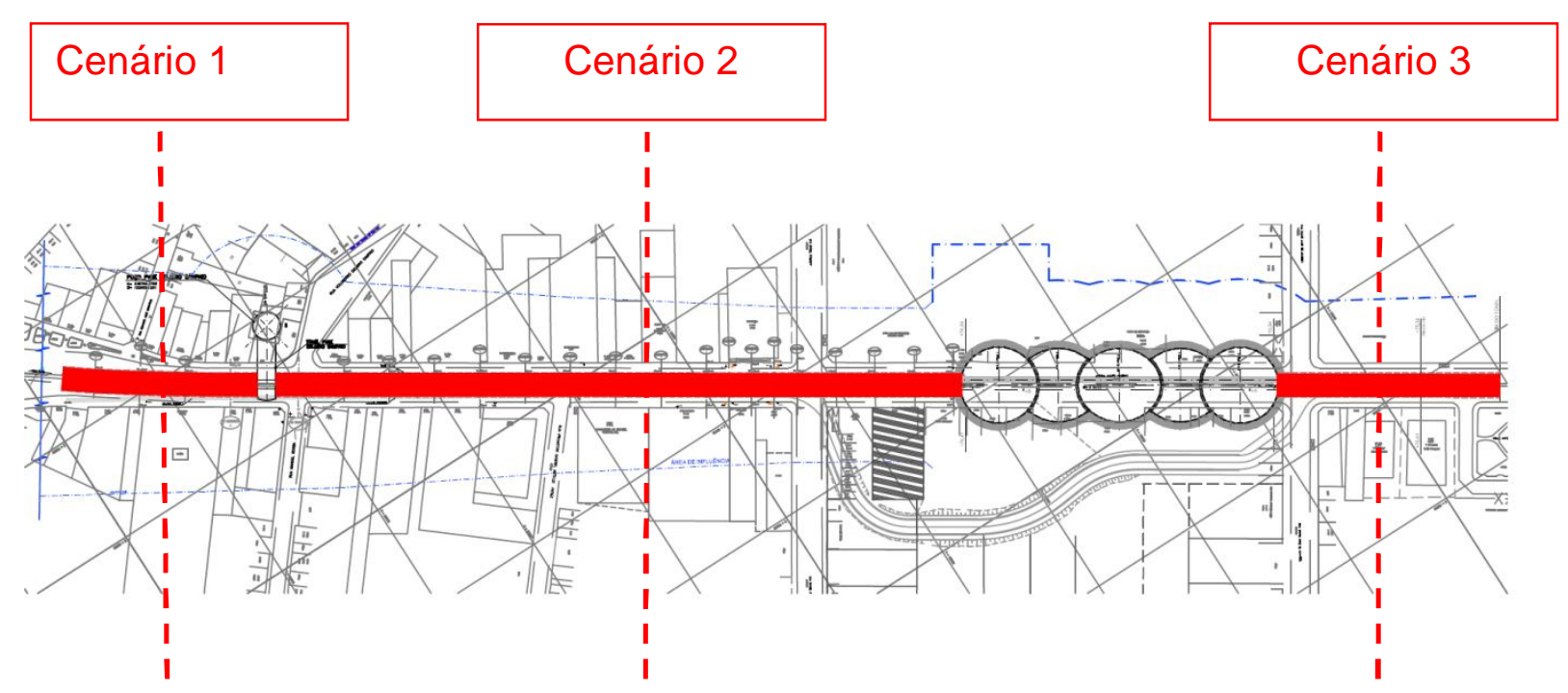

Figura 49 Locação dos cenários geológicos adotados 
Apresentam-se a seguir os perfis geológicos considerados nas análises do túnel de via.

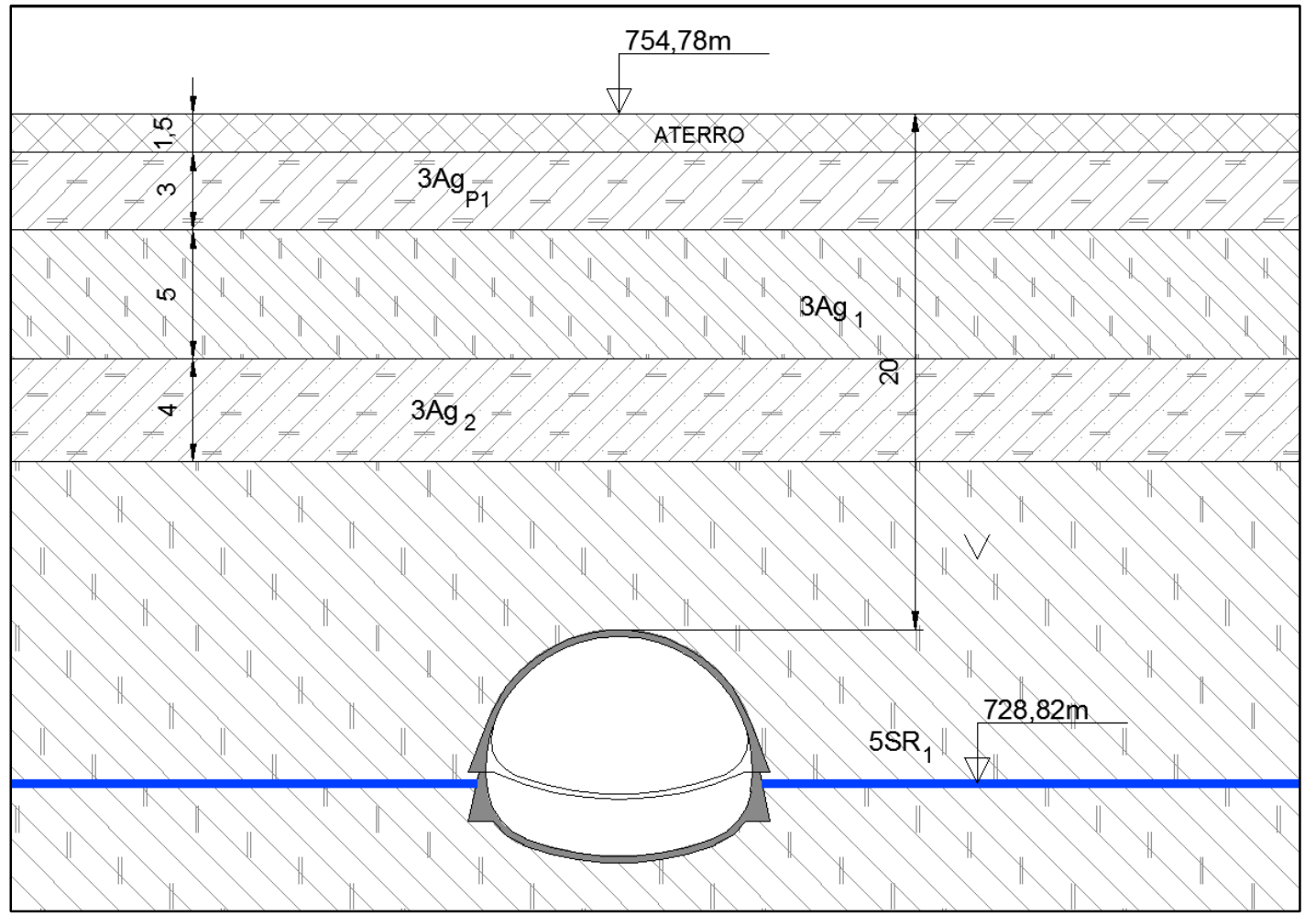

Figura 50 Estratigrafia adotada para o Cenário 1

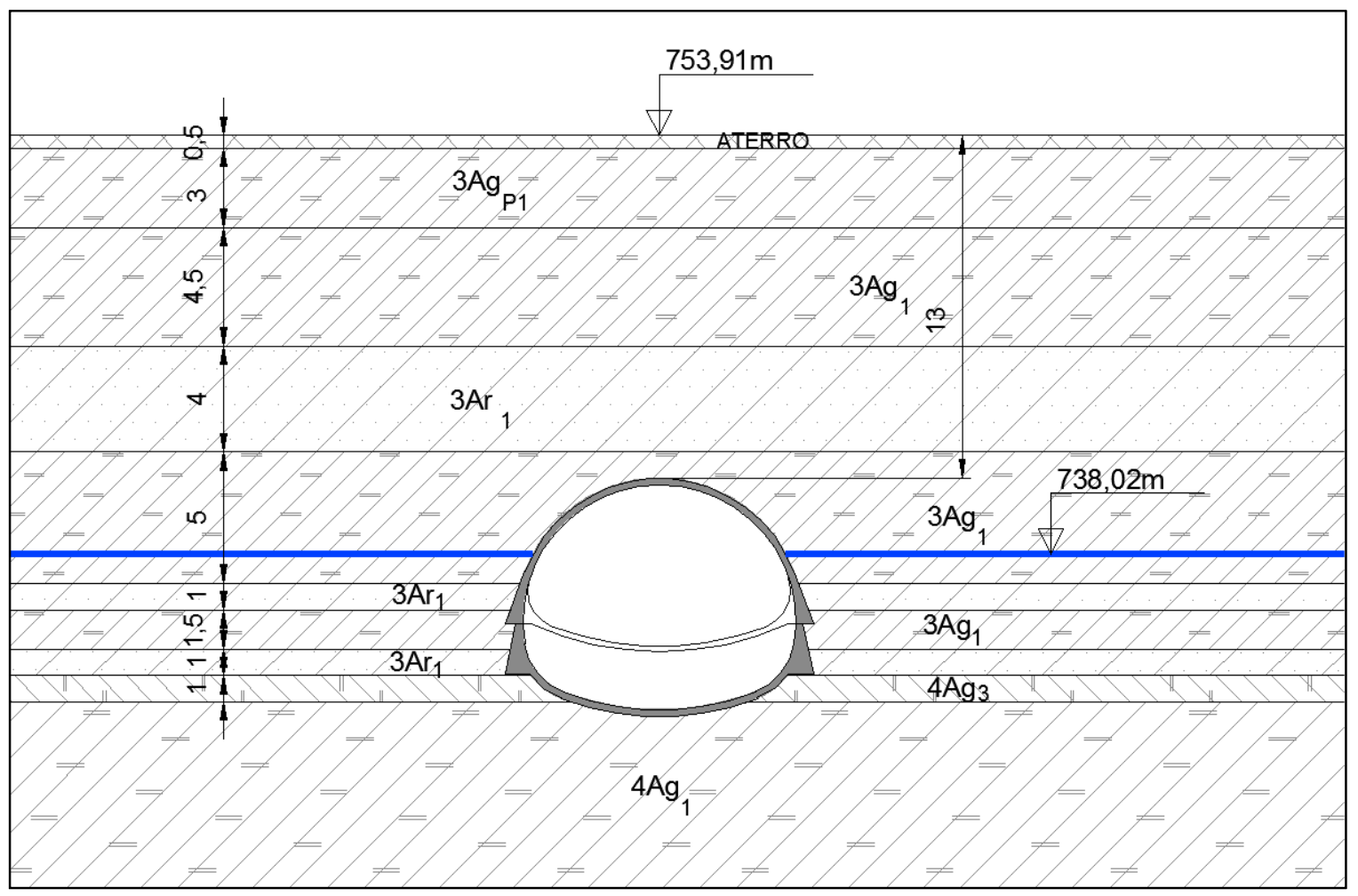

Figura 51 Estratigrafia adotada para o Cenário 2 


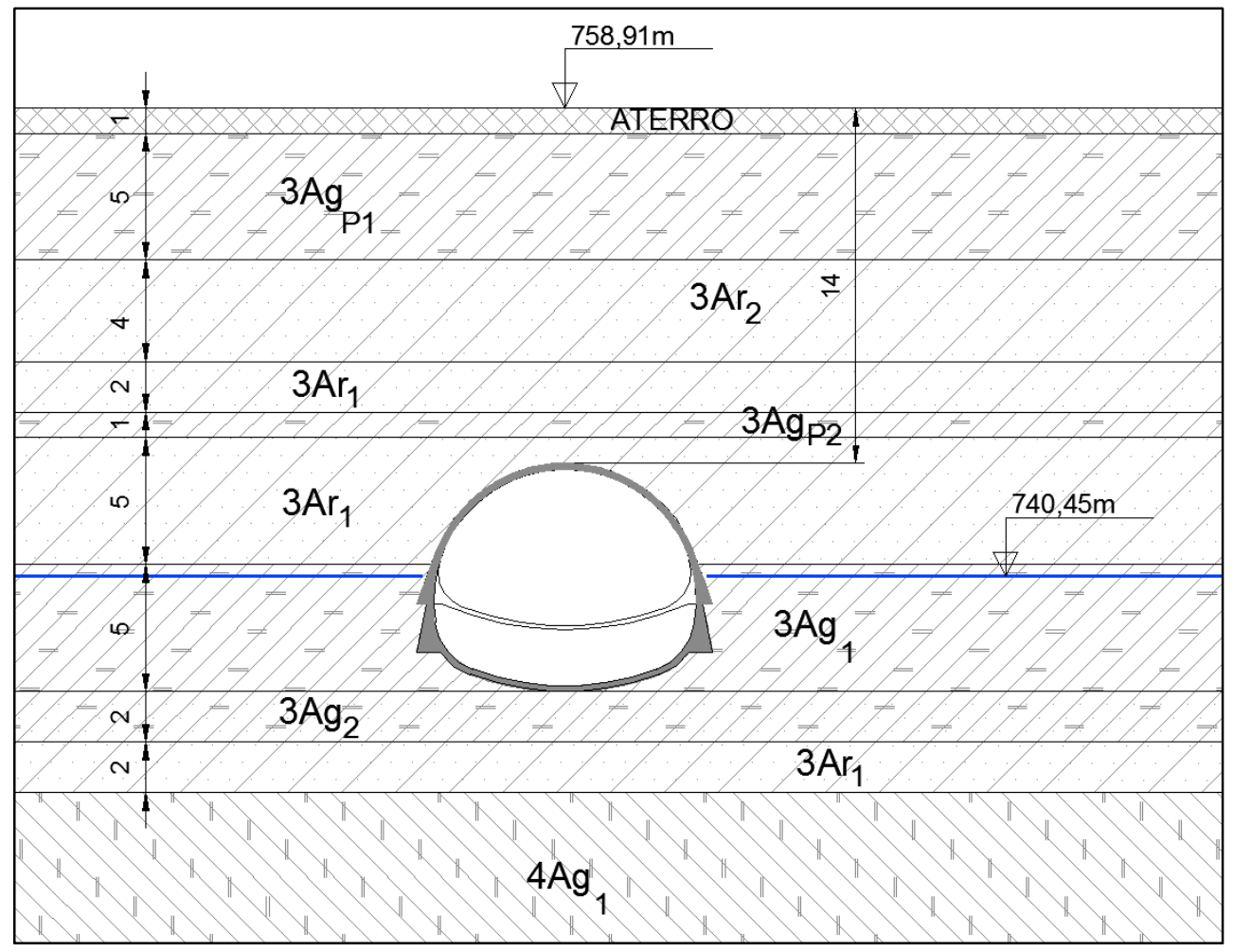

Figura 52 Estratigrafia adotada para o Cenário 3

5.3.1. Nível do lençol freático

Os níveis d'água apresentados nas estratigrafias adotadas referem-se às pressões neutras obtidas por meio dos piezômetros instalados na região do túnel de via. $A$ tabela a seguir, resume as principais características dos instrumentos representativos de cada cenário estudado. Apresenta-se, também, um gráfico com o resultado da piezometria instalada na obra. Os cálculos são executados em tensões efetivas.

\begin{tabular}{|c|c|c|c|c|}
\hline Cenário & Piezômetro & $\begin{array}{c}\text { Cota de topo } \\
(\mathrm{m})\end{array}$ & $\begin{array}{c}\text { Cota de Fundo } \\
(\mathrm{m})\end{array}$ & $\begin{array}{c}\text { Cota do N.A. } \\
(\mathrm{m})\end{array}$ \\
\hline 1 & PZ-07 & 754,0 & 726,75 & 728,82 \\
\hline 2 & PZ-08 & 754,0 & 727,75 & 738,02 \\
\hline 3 & PZ-15 & 758,0 & 733,75 & 740,45 \\
\hline
\end{tabular}

Tabela 4 - Principais características dos instrumentos 


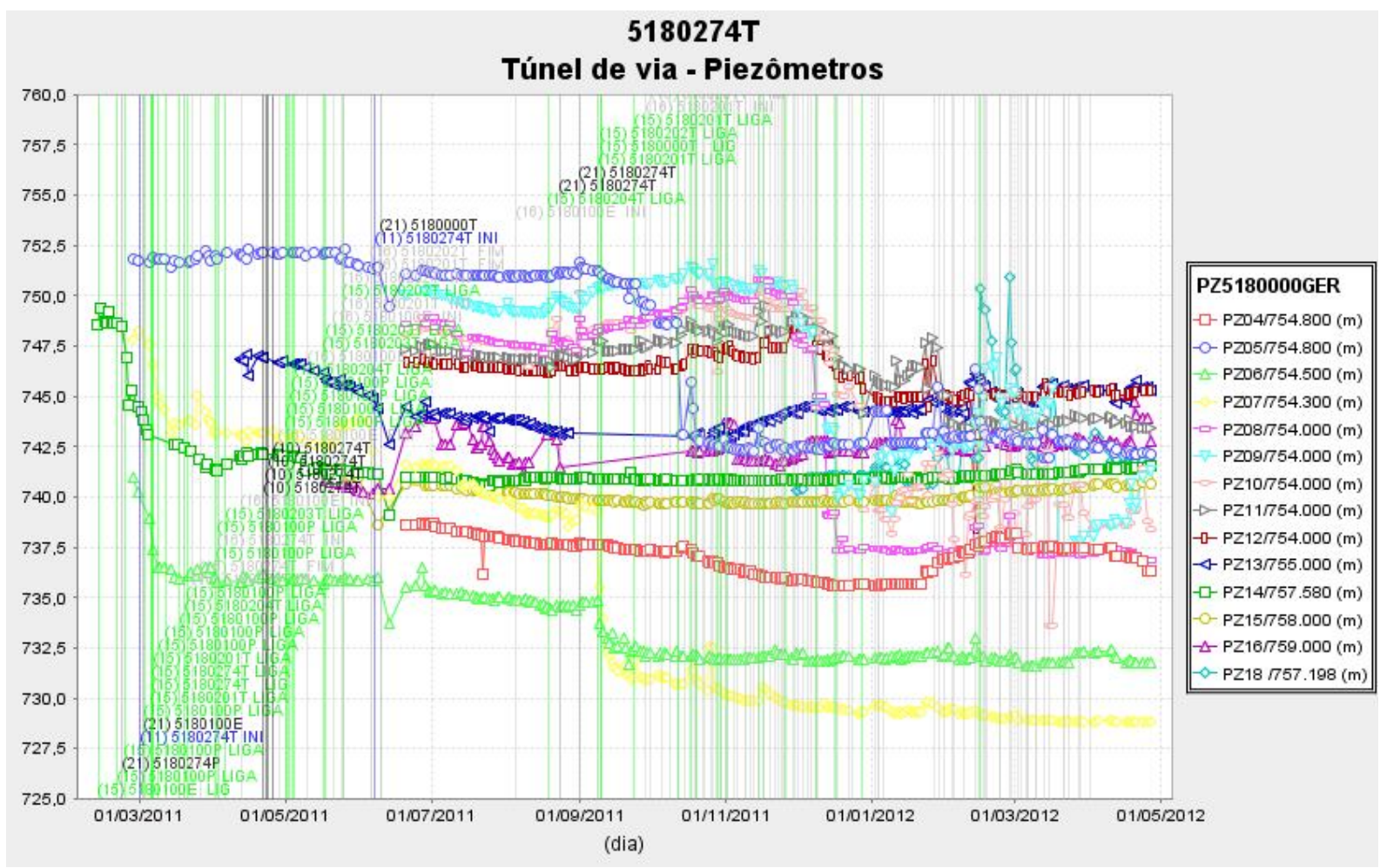

Figura 53 Gráfico dos piezômetros do túnel de via (copiado da Companhia do Metropolitano de São Paulo (32))

5.3.2. Parâmetros dos materiais

Os parâmetros geotécnicos adotados estão apresentados no capítulo 3 deste trabalho. A estratigrafia do subsolo e os parâmetros geotécnicos utilizados nos cálculos para os três cenários geológicos estão sumarizados nas tabelas apresentadas a seguir. 


\begin{tabular}{|c|c|c|c|c|c|}
\hline \multicolumn{2}{|c|}{ Cenário 1} & \multicolumn{2}{|c|}{ Cenário 2} & \multicolumn{2}{|c|}{ Cenário 3} \\
\hline Prof. (m) & Solo & Prof. (m) & Solo & Prof. (m) & Solo \\
\hline $0,00-1,50$ & Aterro & $0,00-0,50$ & Aterro & $0,00-1,00$ & Aterro \\
\hline $1,50-4,50$ & $3 \mathrm{AgP}_{1}$ & $0,50-3,50$ & $3 \mathrm{AgP}_{1}$ & $1,00-6,00$ & $3 \mathrm{AgP}_{1}$ \\
\hline $4,50-9,50$ & $3 \mathrm{Ag}_{1}$ & $3,50-8,00$ & $3 \mathrm{Ag}_{1}$ & $6,00-10,00$ & $3 \mathrm{Ar}_{2}$ \\
\hline $9,50-13,50$ & $3 \mathrm{Ag}_{2}$ & $8,00-12,00$ & $3 A r_{1}$ & $10,00-12,00$ & $3 \mathrm{Ar}_{1}$ \\
\hline $13,50-$ & $5 \mathrm{SR}_{1}$ & $12,00-17,00$ & $3 \mathrm{Ag}_{1}$ & $12,00-13,00$ & $3 \mathrm{AgP}_{2}$ \\
\hline & & $17,00-18,00$ & $3 \mathrm{Ar}_{1}$ & $13,00-18,00$ & $3 \mathrm{Ar}_{1}$ \\
\hline & & $18,00-19,50$ & $3 \mathrm{Ag}_{1}$ & $18,00-23,00$ & $3 \mathrm{Ag}_{1}$ \\
\hline & & $19,50-20,50$ & $3 \mathrm{Ar}_{1}$ & $23,00-25,00$ & $3 \mathrm{Ag}_{2}$ \\
\hline & & $20,50-21,50$ & $4 \mathrm{Ag}_{3}$ & $25,00-27,00$ & $3 \mathrm{Ar}_{1}$ \\
\hline & & $21,50-$ & $4 \mathrm{Ag}_{1}$ & $25,00-$ & $4 \mathrm{Ag}_{1}$ \\
\hline \begin{tabular}{|c|} 
Prof. do Túnel \\
$(\mathrm{m})$
\end{tabular} & 20,00 & & 13,00 & & 14,00 \\
\hline
\end{tabular}

Tabela 5 - Estratigrafias adotadas

\begin{tabular}{|c|c|c|c|c|c|}
\hline Tipo de Solo & $\mathrm{E}(\mathrm{Mpa})$ & $\gamma\left(\mathrm{tf} / \mathrm{m}^{3}\right)$ & $\mathrm{c}^{\prime}\left(\mathrm{tt} / \mathrm{m}^{2}\right)$ & $\varnothing^{\prime}\left(^{\circ}\right)$ & $\mathrm{K}_{\circ}$ \\
\hline Aterro & 8 & 1,6 & 1,0 & 20 & 0,66 \\
\hline $3 \mathrm{AgP}{ }_{1}$ & 10 & 1,6 & 2,0 & 27 & 0,55 \\
\hline $3 \mathrm{AgP}_{2}$ & 10 & 1,7 & 4,0 & 25 & 0,58 \\
\hline $3 \mathrm{Ag}_{1}$ & 44 & 1,9 & 7,5 & 21 & 0,64 \\
\hline $3 \mathrm{Ag}_{2}$ & 64 & 1,9 & 4,0 & 21 & 0,64 \\
\hline $3 \mathrm{Ar}_{1}$ & 50 & 1,9 & 0,3 & 32 & 0,47 \\
\hline $3 \mathrm{Ar}_{2}$ & 34 & 1,9 & 0,1 & 30 & 0,50 \\
\hline $4 \mathrm{Ag}_{1}$ & 96 & 2,0 & 5,0 & 21 & 0,64 \\
\hline $4 \mathrm{Ag}_{3}$ & 172 & 2,0 & 3,0 & 27 & 0,55 \\
\hline $5 \mathrm{SR}_{1}$ & 60 & 2,0 & 2,0 & 30 & 0,50 \\
\hline
\end{tabular}

Tabela 6 - Parâmetros geotécnicos adotados

Para todos os materiais acima foi adotado coeficiente de Poisson igual a 0,3, maciço isotrópico e Estado Plano de Deformações com elementos elásticos ou elastoplásticos ideais, ou seja, os parâmetros de resistência se mantêm iguais após a plastificação, (dilatância igual a zero).

De acordo com Pinto (29), em um solo formado pela sedimentação livre dos grãos, a tensão vertical é o produto do peso específico pela espessura da camada. As tensões horizontais também aumentam com a profundidade, porém não com 0 
mesmo valor, em virtude do atrito entre as partículas. A relação entre a tensão horizontal efetiva e a tensão vertical efetiva é denominada coeficiente de empuxo em repouso, indicado pelo símbolo $\mathrm{K}_{0}$.

$\mathrm{Na}$ definição das tensões iniciais do modelo, foi considerado o valor de $\mathrm{K}_{0}$ para os materiais acima, de acordo com a fórmula empírica, que foi confirmada por vários pesquisadores e é conhecida pelo nome de seu autor, a "formula de Jaki".

$$
K_{0}=1-\sin \left(\phi^{\prime}\right)
$$

\subsubsection{Concreto projetado}

O revestimento primário foi simulado com as seguintes características:

- $\mathrm{f}_{\mathrm{ck}}=30 \mathrm{MPa}$

- $E=30.672,5 \mathrm{MPa}\left(\mathrm{E}=5600 . \mathrm{f}_{\mathrm{ck}}{ }^{1 / 2}-\mathrm{NBR} 6118: 2003(33)\right)$

- $v=0,20$

Considerou-se a envoltória de resistência do concreto simples, apresentada por Fusco (34), dada por:

$$
\tau=0,2 \cdot f_{c k}+0,9 \sigma_{c c}
$$

Em que:

$\tau$ - Tensão de cisalhamento

$\sigma_{\mathrm{cc}}-$ Tensão à compressão

$\mathrm{f}_{\mathrm{ck}}$ - Resistência característica à compressão do concreto

Dessa forma, adotou-se uma coesão de $600 \mathrm{tf} / \mathrm{m}^{2}$ e um ângulo de atrito igual a $42^{\circ}$.

\subsubsection{Sistema de Unidades utilizado}

Força: tf;

Tensão: tf/m²;

Comprimento: $\mathrm{m}$;

Massa Específica: t/m³; 


\subsubsection{Dimensões da malha}

A partir da experiência com análises numéricas e de acordo com as recomendações da literatura, estabeleceu-se o tamanho adequado da malha a ser empregada, que, por um lado, não deforme os resultados, e, por outro, não seja demasiadamente grande que onere desnecessariamente o tempo de processamento.

Alguns critérios auxiliaram o desenvolvimento da primeira malha. Por exemplo, zonas onde se esperavam maiores alterações de tensões foram representadas por discretizações mais refinadas, ao passo que em zonas com pouca alteração de tensões foram utilizados elementos de maiores dimensões.

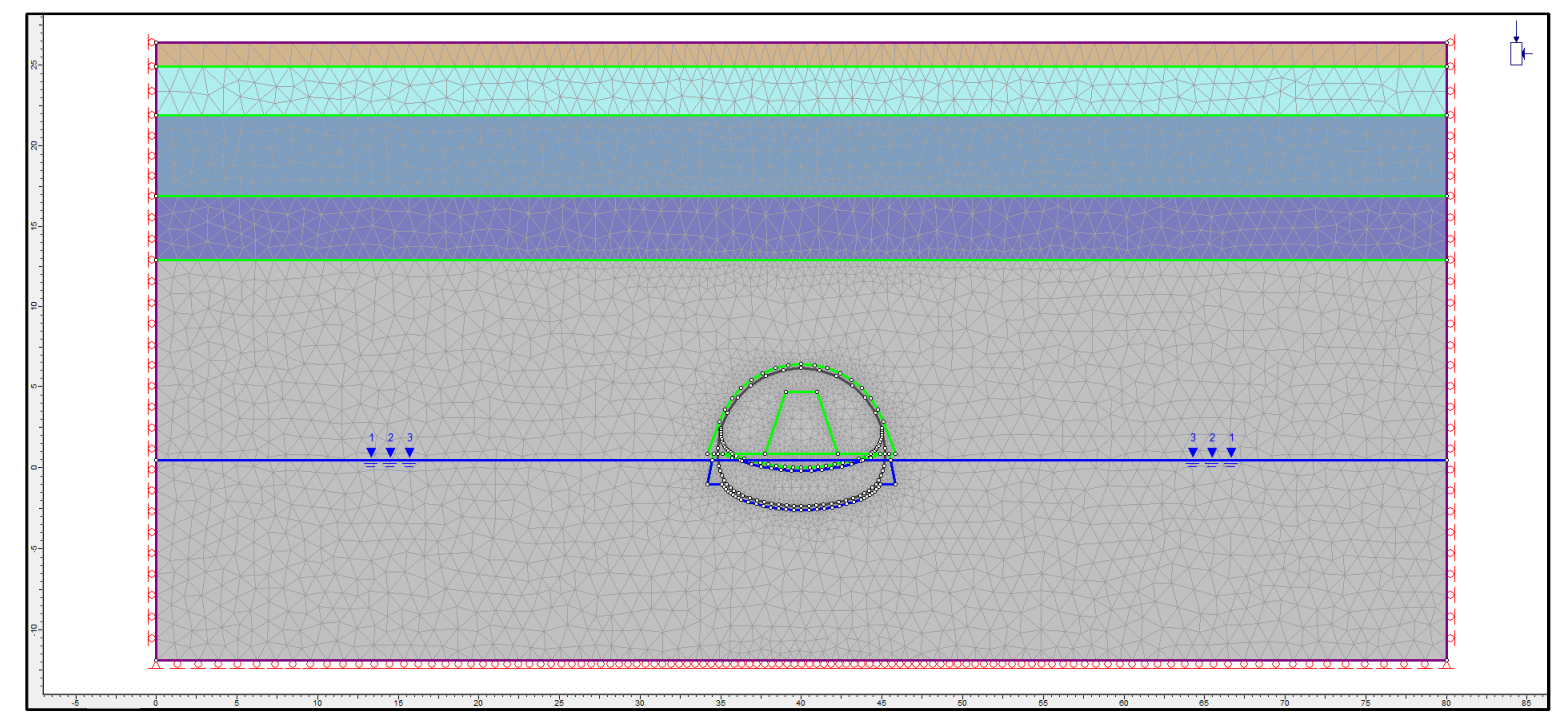

Figura 54 Discretização do modelo geológico-geotécnico em malha de elementos finitos e condições de contorno adotado para o Cenário 1 


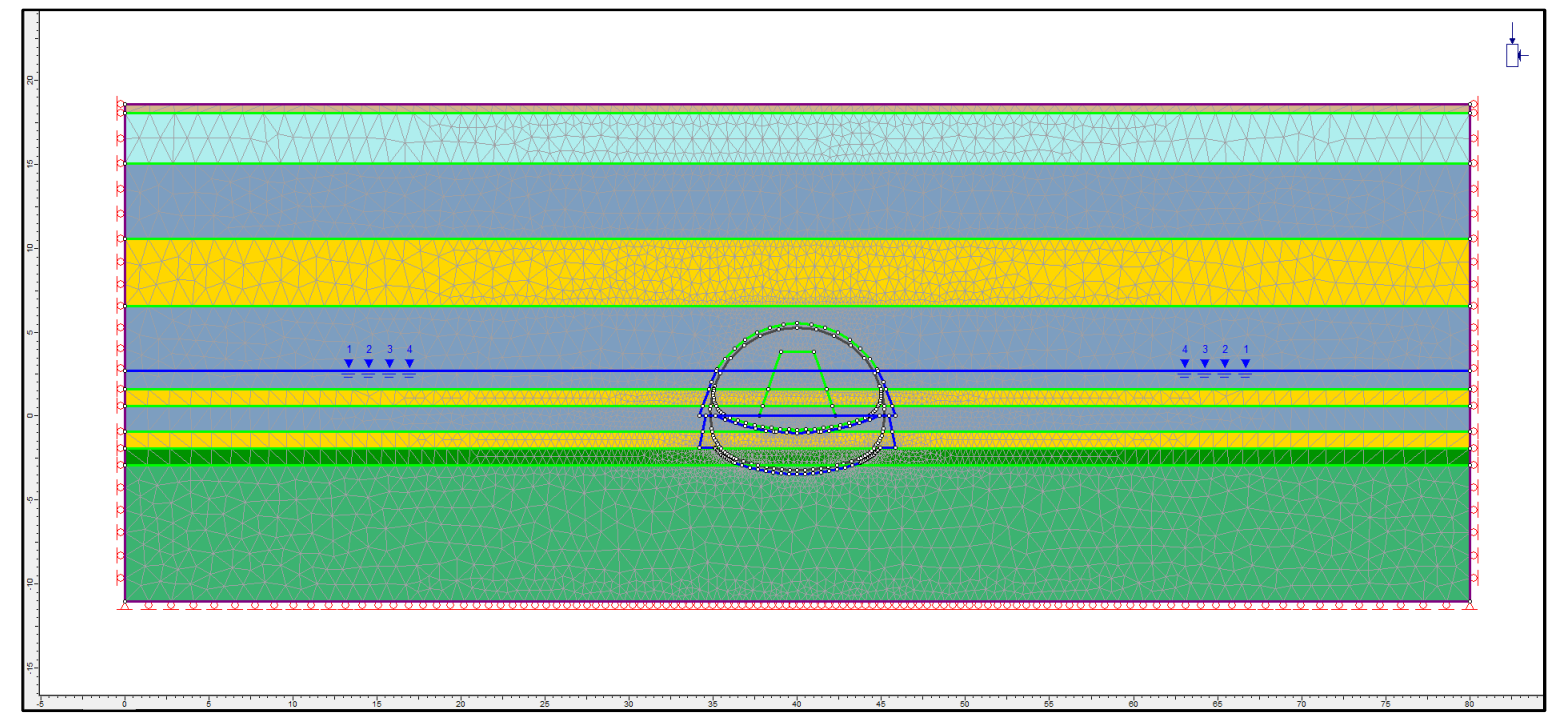

Figura 55 Discretização do modelo geológico-geotécnico em malha de elementos finitos e condições de contorno adotado para o Cenário 2

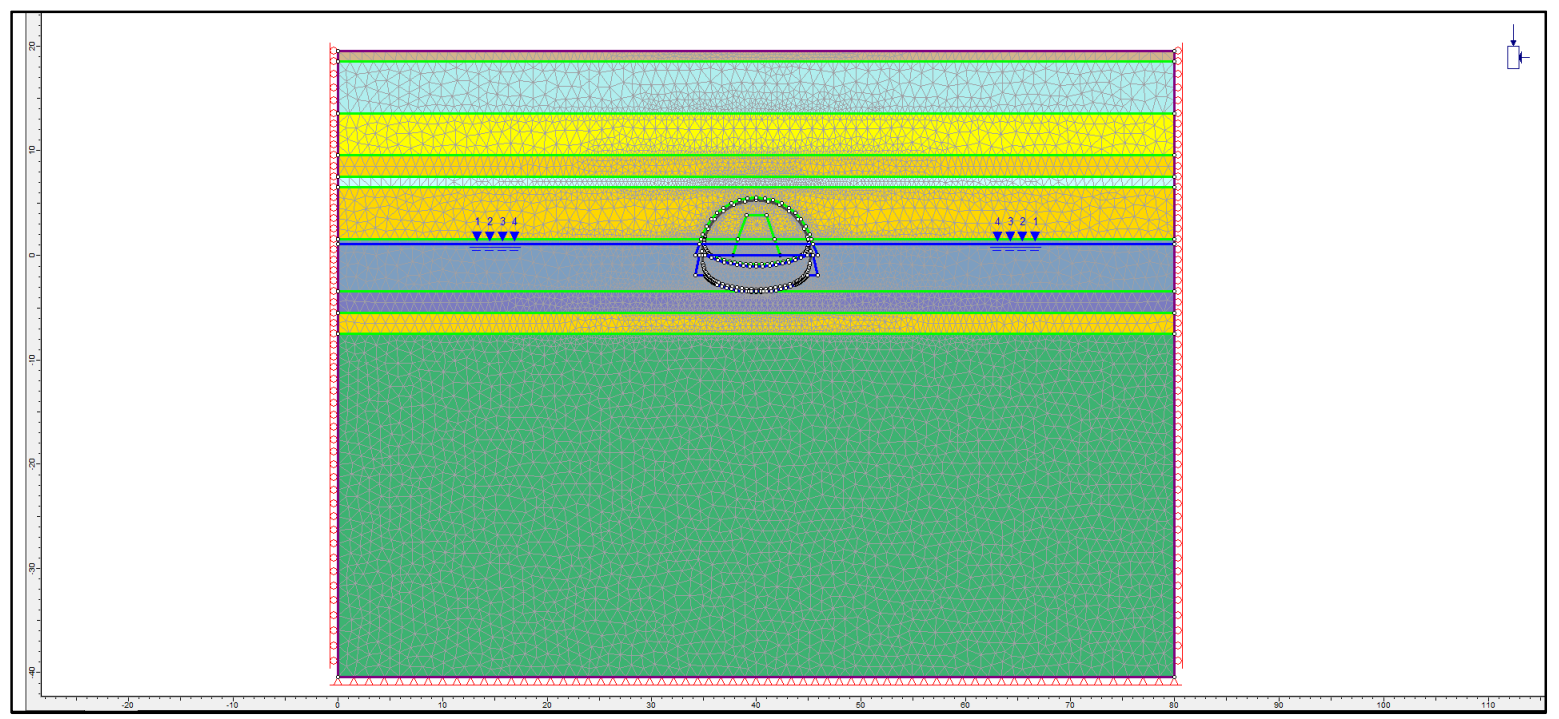

Figura 56 Discretização do modelo geológico-geotécnico em malha de elementos finitos e condições de contorno adotado para o Cenário 3

\subsubsection{Modelo de cálculo}

Para a estimativa das deformações, foi empregado o método dos elementos finitos (MEF), utilizando-se o programa Phase2, modelo evolutivo de carregamento espontâneo, com fases que simulam as diversas etapas construtivas. 
Na verificação das deformações, o modelo de cálculo mais adequado é o Modelo de Ações Espontâneas (M.A.E.), levando em conta as fases construtivas.

No M.A.E., a interação entre o maciço e a estrutura determina o carregamento no revestimento, já que este é definido pelas tensões internas da estrutura constituída do maciço e do revestimento.

As simulações foram feitas por meio de modelo evolutivo, levando-se em consideração a trajetória de tensões no maciço e o histórico da sequência de execução da estrutura e aplicação das solicitações provenientes da escavação.

Para simular os efeitos tridimensionais de escavação, utiliza-se a técnica conhecida como material softening (redução progressiva do Módulo de Elasticidade do solo no interior do túnel).

Para simular o enrijecimento do concreto projetado, que se dá em um estágio após a sua aplicação, utiliza-se um acréscimo progressivo do Módulo de Elasticidade do revestimento.

O modelo evolutivo foi representado em estágios, com o propósito de simular as diversas etapas construtivas. São eles:

a) Determinação das tensões iniciais e "zeragem" dos deslocamentos;

b) Escavação da calota;

c) Instalação do revestimento primário na calota;

d) Escavação do arco invertido provisório;

e) Instalação do arco invertido provisório;

f) Escavação do arco invertido definitivo;

g) Instalação do arco invertido definitivo.

\subsubsection{Fases de cálculo}

Apresenta-se abaixo uma descrição das fases dos processamentos numéricos realizados.

Pode-se notar que, no primeiro estágio, os modelos não apresentam nenhuma escavação ou suporte instalado, de modo a simular o estado de tensões "in situ". 
- Fase 1: definição da malha de elementos finitos e aplicação das tensões "in situ". As tensões verticais são resultados da ação da aceleração da gravidade; as tensões horizontais nas duas direções são resultados do efeito das tensões verticais afetadas pelo $\mathrm{k}_{0}$.

- Fases 2 a 4: redução progressiva do Módulo de Elasticidade do solo no interior da calota, para simular os passos de avanço da escavação da calota do túnel, com alívio das tensões existentes. Isso corresponde ao avanço da frente de escavação, até o instante imediatamente anterior à instalação do revestimento.

- Fase 5: escavação da calota.

- Fases 4 a 7: acréscimo progressivo do Módulo de Elasticidade do revestimento de concreto projetado da calota, para simular o ganho de resistência do mesmo.

- Fases 8 a 10: redução progressiva do Módulo de Elasticidade do solo no interior do núcleo e arco invertido provisório (AIP), para simular os efeitos tridimensionais de escavação.

- Fase 11: escavação do AIP.

- Fases 10 a 13: acréscimo progressivo do Módulo de Elasticidade do revestimento de concreto projetado do AIP, para simular o ganho de resistência do mesmo.

- Fases 14 a 16: redução do Módulo de Elasticidade do solo do arco invertido definitivo (AID), para simular os efeitos tridimensionais de escavação do mesmo.

- Fase 16: retirada do revestimento do AIP, para simular a demolição do mesmo.

- Fase 17: escavação do AID do túnel.

- Fases 16 a 19: acréscimo progressivo do Módulo de Elasticidade do revestimento de concreto projetado do AID, para simular o ganho de resistência do mesmo.

O alívio das tensões existentes corresponde ao avanço da frente de escavação de cada etapa (calota, AIP e AID), e este foi considerado reduzindo o Módulo de Elasticidade do solo em três fases: $75 \%$ do E, $50 \%$ do E e $25 \%$ do $E$, até o instante imediatamente anterior à instalação dos revestimentos. O ganho de resistência do 
concreto projetado foi considerado como acréscimo do Módulo de Elasticidade em quatro fases: $25 \%$ do E, $50 \%$ do $E, 75 \%$ do $E$ e $100 \%$ do $E$.

\subsection{Resultados obtidos}

Neste trabalho foram elaborados diversos modelos numéricos para estudar o comportamento do túnel em questão. Foram utilizados dois tipos de modelo, 1representando os materiais como elasto-plásticos ideais e 2- representando os materiais como elásticos. Os modelos com material elasto-plástico ideal apresentaram problemas de convergência, em função da concentração de tensões no revestimento (extremidade das sapatas). Ao analisar os resultados dos dois tipos de modelo, verificou-se que o segundo tipo representa melhor os deslocamentos reais no maciço, aferidos pela instrumentação da obra. Portanto, neste item apresentam-se apenas os resultados dos modelos que representam os materiais com comportamento elástico.

Os cálculos efetuados possibilitaram a obtenção de um quadro representativo do estado de tensões a que estará submetido o maciço após a escavação, bem como dos campos de deslocamentos e esforços solicitantes nos elementos estruturais do suporte provisório. A seguir, apresentam-se os resultados obtidos em termos de:

- Estado de tensões iniciais no maciço, diagramas de tensões principais máximas $(\sigma 1)$;

- Análise da Teoria das Cascas;

- Análise do arqueamento das tensões no solo;

- Análise do caminhamento das cargas na estrutura.

\subsubsection{Condições iniciais}

Para o início dos cálculos, foi necessária a determinação do estado inicial de tensões. O estado de tensões inicial foi estimado adotando-se os valores de peso específico dos solos e coeficiente de empuxo em repouso $\left(\mathrm{K}_{0}\right)$, listados no subitem 5.3.2. 


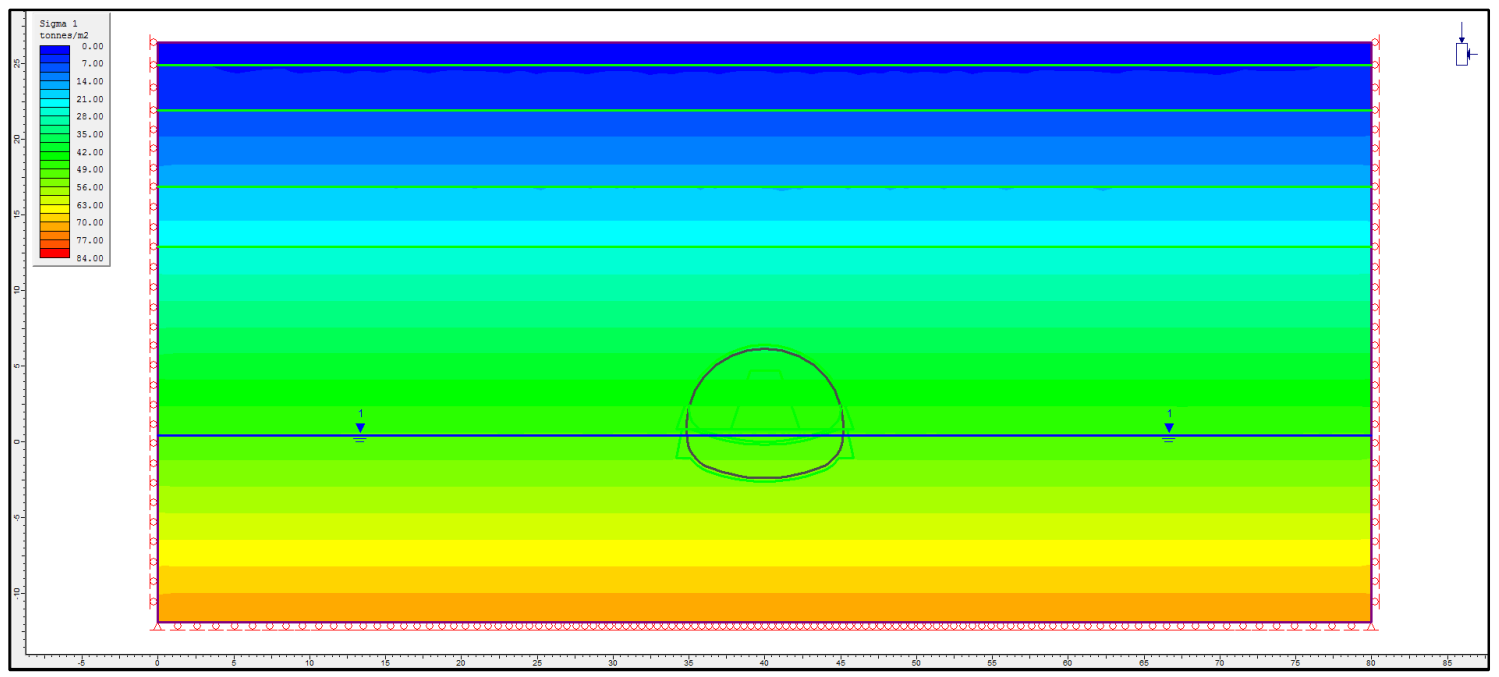

Figura 57 Campo de tensões iniciais $\left(\sigma_{1}\right)$ para o Cenário 1

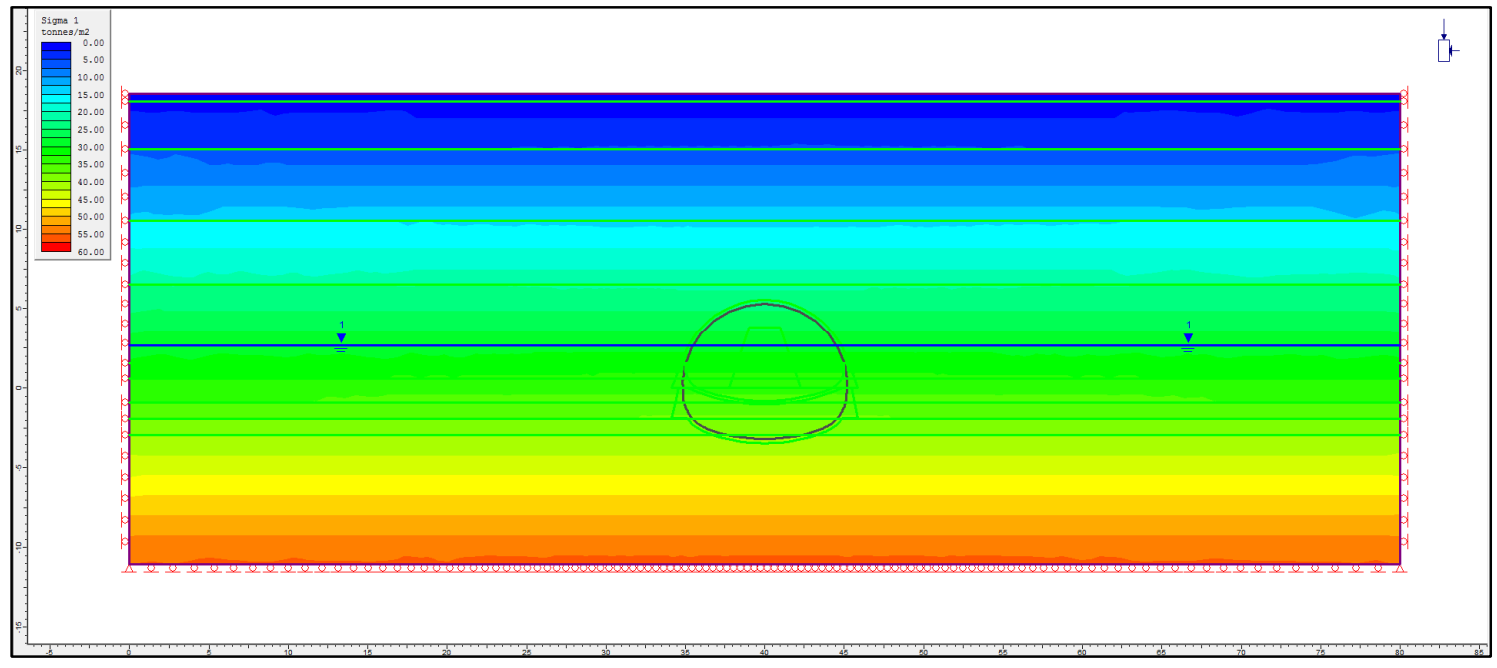

Figura 58 Campo de tensões iniciais $\left(\sigma_{1}\right)$ para o Cenário 2

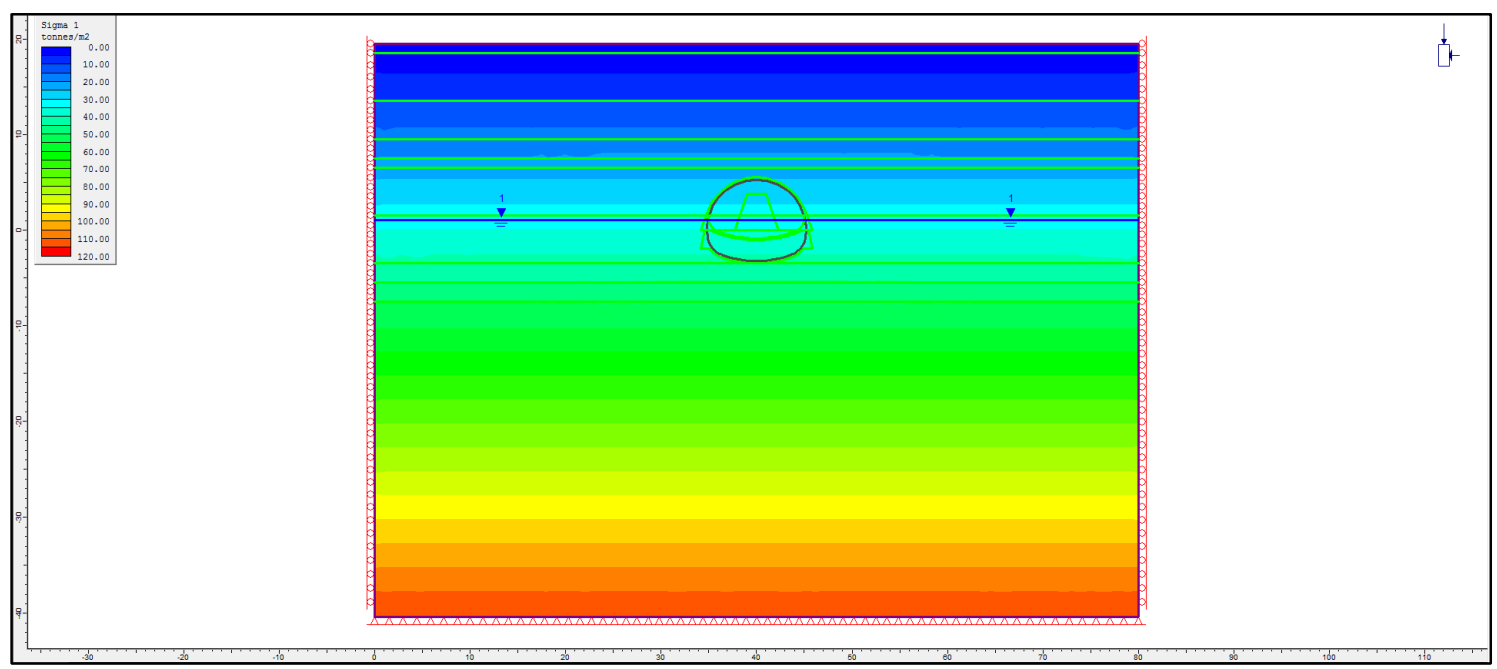

Figura 59 Campo de tensões iniciais $\left(\sigma_{1}\right)$ para o Cenário 3 


\subsubsection{Verificações pela Teoria das Cascas}

As análises das tensões no revestimento da calota do túnel, apresentadas a seguir, são elaboradas à luz da Teoria das Cascas. O revestimento do túnel é um corpo tridimensional, sendo que uma das suas dimensões é muito menor do que as outras duas e a curvatura da sua superfície média na configuração inicial não é nula, enquadrando-se na Teoria das Cascas. É importante notar que as forças de membrana são independentes da flexão e são totalmente definidas pelas condições de equilíbrio estático; portanto, os esforços internos do revestimento são predominantemente de compressão.

Os diagramas de tensões principais $\left(\sigma_{1}\right)$, na última fase da modelagem (Fase 19), foram utilizados nas análises. Nessa fase da modelagem, as escavações e execução do revestimento estão concluídas. Através dos diagramas podem-se averiguar as tensões normais no revestimento. Conforme explanado no item 4.1, com a espessura do revestimento e o raio de curvatura da casca, é possível calcular o carregamento sobre a membrana, por meio da expressão $\mathrm{N}=\mathrm{p}^{\star}$ r. Com isso, podem-se comparar os resultados obtidos com o carregamento atuante, como no modelo. Os dados para análise serão obtidos da geratriz superior do revestimento do túnel.

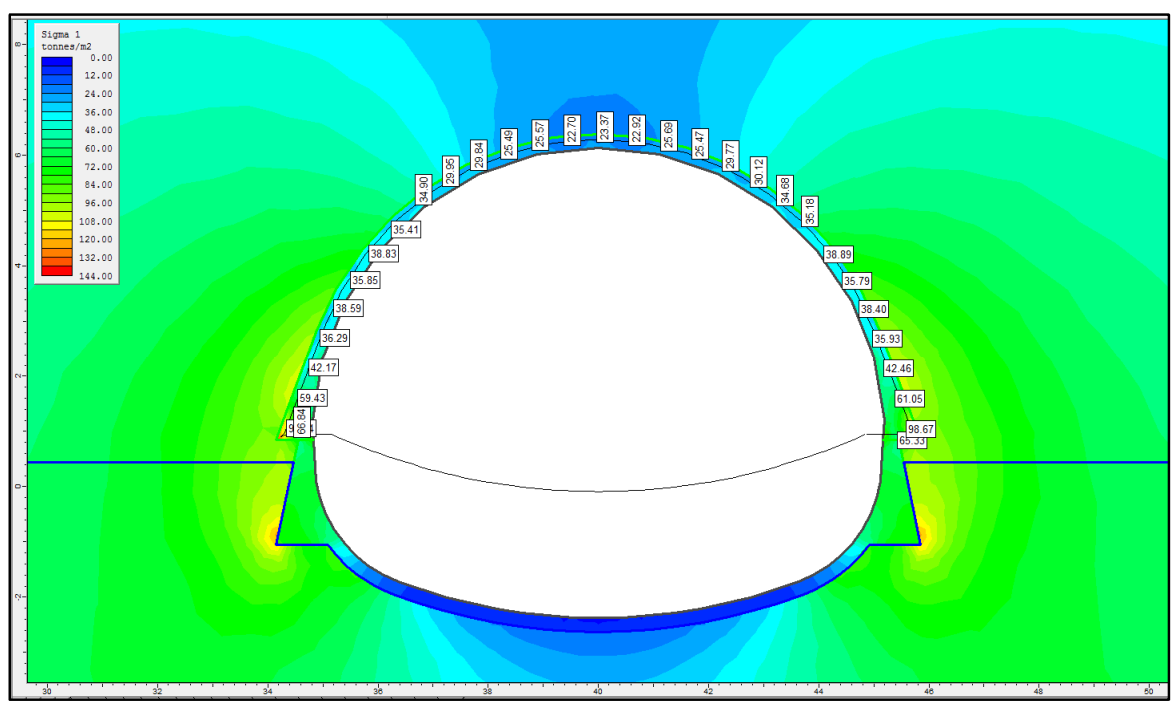

Figura 60 Campo de tensões $\left(\sigma_{1}\right)$ para o Cenário 1 


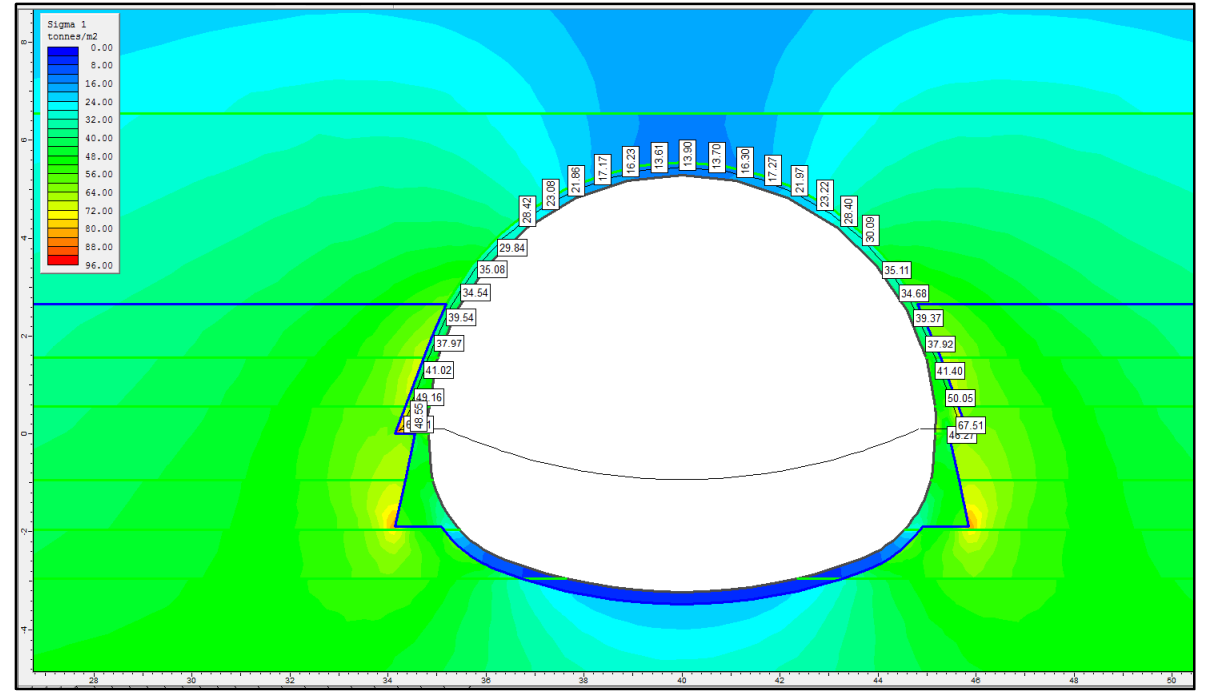

Figura 61 Campo de tensões $\left(\sigma_{1}\right)$ para o Cenário 2

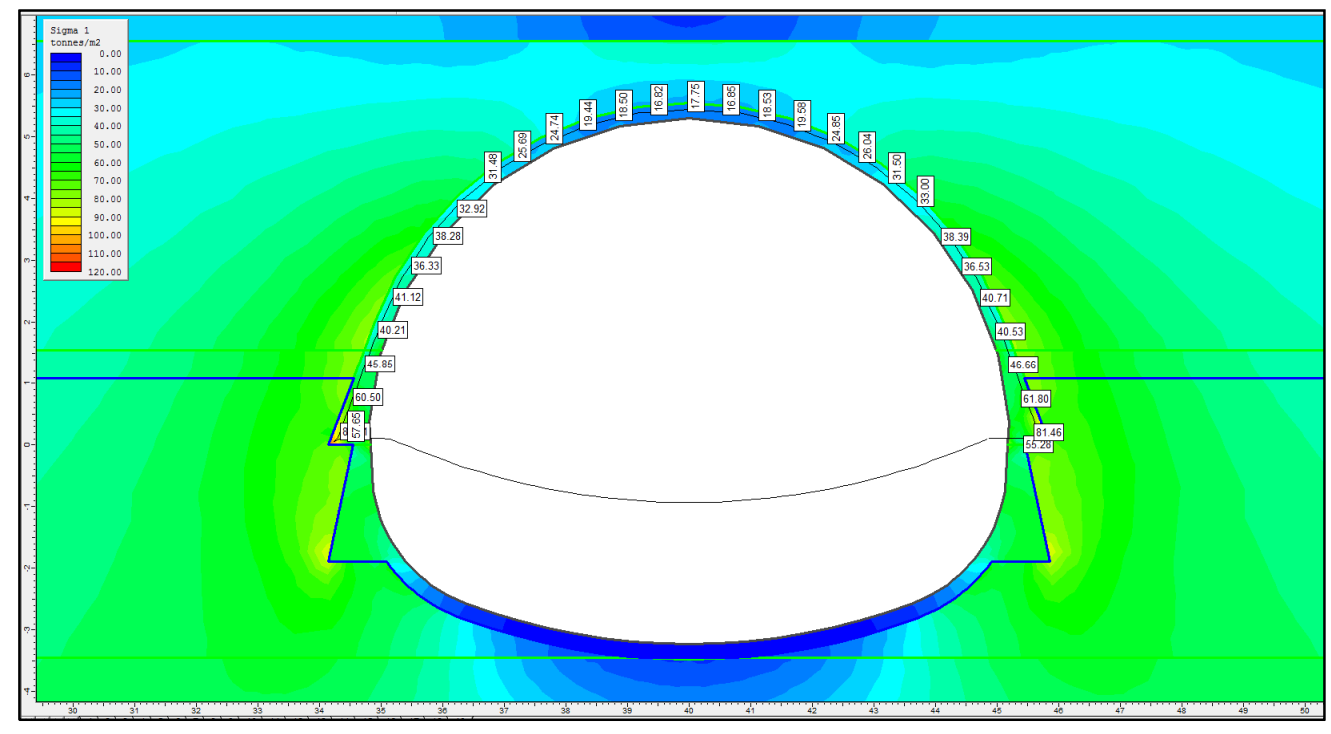

Figura 62 Campo de tensões $\left(\sigma_{1}\right)$ para o Cenário 3

\begin{tabular}{|l|c|c|c|c|c|}
\hline & $\sigma_{N}$ & $\mathrm{e}(\mathrm{rev})$. & $\mathrm{r}($ raio $)$ & $P($ teoria das cascas $)$ & $P($ modelagem $)$ \\
\cline { 2 - 6 } & $\left(\mathrm{tf} / \mathrm{m}^{2}\right)$ & $(\mathrm{m})$ & $(\mathrm{m})$ & $\left(\mathrm{tf} / \mathrm{m}^{2}\right)$ & $\left(\mathrm{tf} / \mathrm{m}^{2}\right)$ \\
\hline Cenário 1 & 23,37 & 0,25 & 5,445 & 1,07 & 0,94 \\
\hline Cenário 2 & 13,90 & 0,25 & 5,445 & 0,64 & 0,63 \\
\hline Cenário 3 & 17,75 & 0,25 & 5,445 & 0,81 & 0,84 \\
\hline
\end{tabular}

Tabela 7 - Comparação entre o carregamento teórico e o da modelagem numérica

\section{Em que:}

$\sigma_{N}-$ tensão normal ao revestimento; 
e - espessura do revestimento;

$r$ - raio de curvatura do revestimento;

P(teoria das cascas) - carregamento atuante no revestimento obtido por meio da teoria de $\operatorname{cascas}\left(\mathrm{N}=\mathrm{p}^{\star} \mathrm{r}\right)$;

$P($ modelagem $)$ - carregamento atuante no revestimento obtido através da modelagem numérica.

O carregamento real no revestimento varia em função do tipo de maciço, geometria, método construtivo etc. Sabe-se, por dados experimentais, que este valor corresponde ao peso de uma camada de solo, com espessura variando de 0,3 a 0,4 do diâmetro do túnel.

Em função do arqueamento das tensões no maciço, as tensões $\sigma 3$ correspondem ao carregamento no revestimento. A seguir são apresentados os diagramas das tensões $\sigma 3$ em cada cenário. Para melhor visualização, será apresentada uma vista ampliada da geratriz superior do túnel.

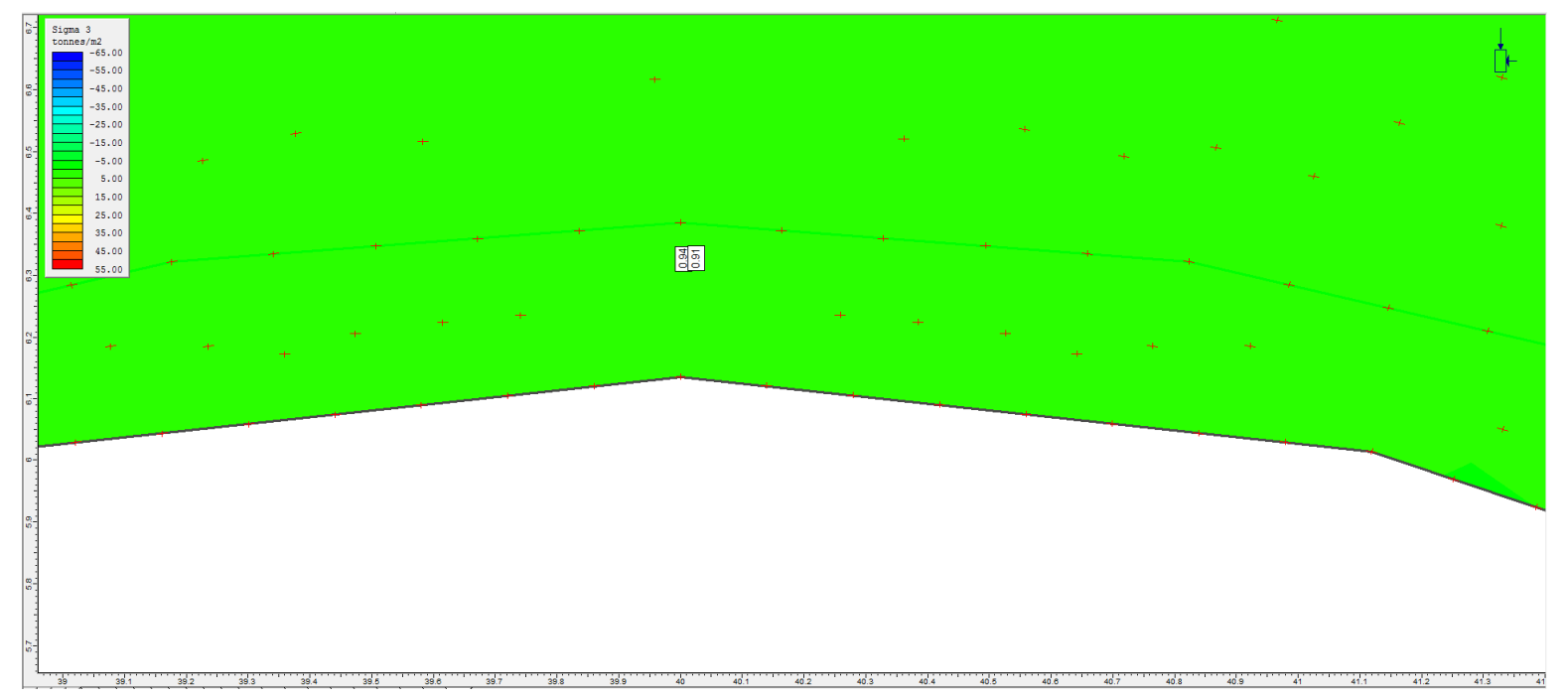

Figura 63 Campo de tensões $\left(\sigma_{3}\right)$ para o Cenário 1 


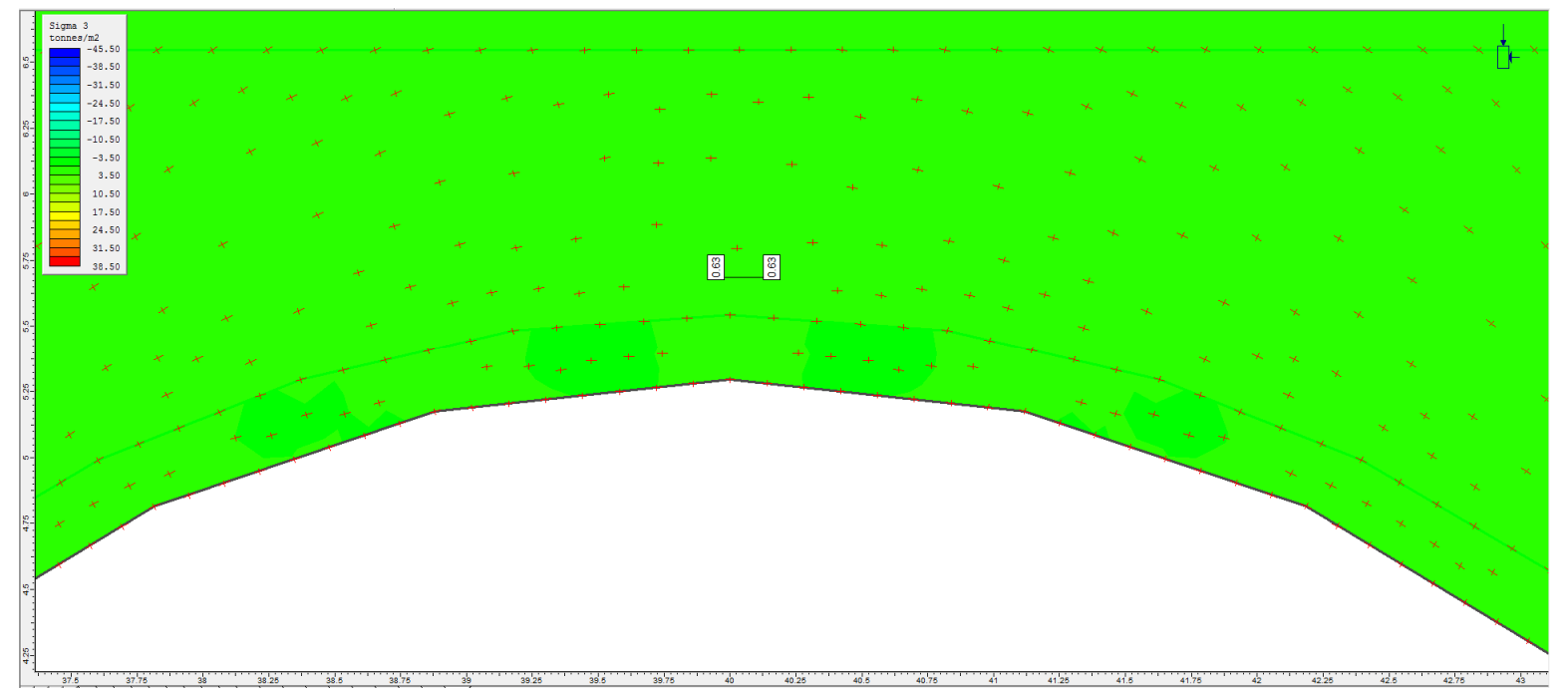

Figura 64 Campo de tensões $\left(\sigma_{3}\right)$ para o Cenário 2

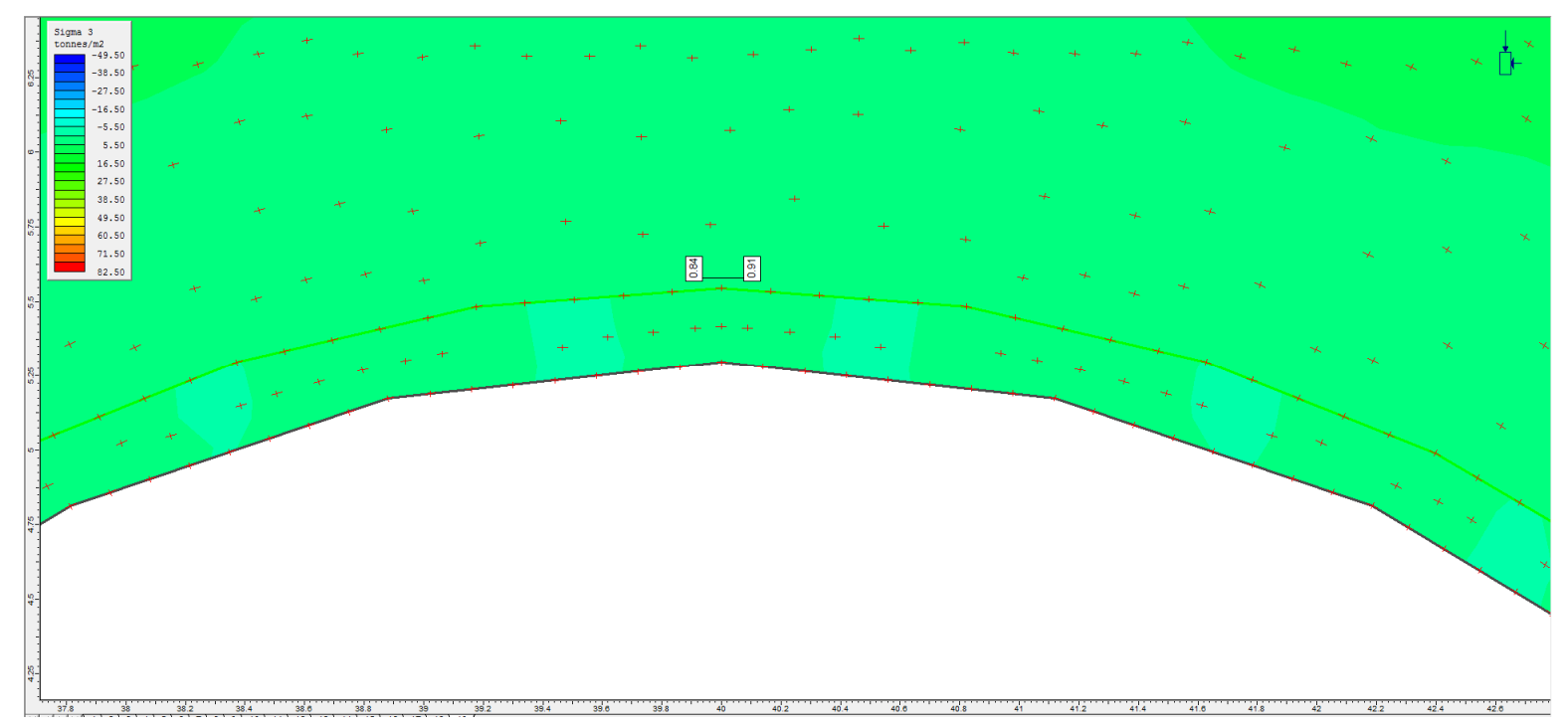

Figura 65 Campo de tensões $\left(\sigma_{3}\right)$ para o Cenário 3

Dessa forma, pode-se concluir que os carregamentos obtidos da Teoria das Cascas são muito próximos aos carregamentos do método numérico. É importante notar que a magnitude dos carregamentos é reduzida, pois se trata de um MAE (Modelo de Ações Espontâneas). A estrutura do revestimento deve ser dimensionada por meio do MAI (Modelo de Ações Impostas).

5.4.4 Análise do arqueamento das tensões do solo

Conforme se pode observar na Figura 66, inicialmente (fase 1 da modelagem), os vetores das tensões principais encontram-se na horizontal e vertical. 


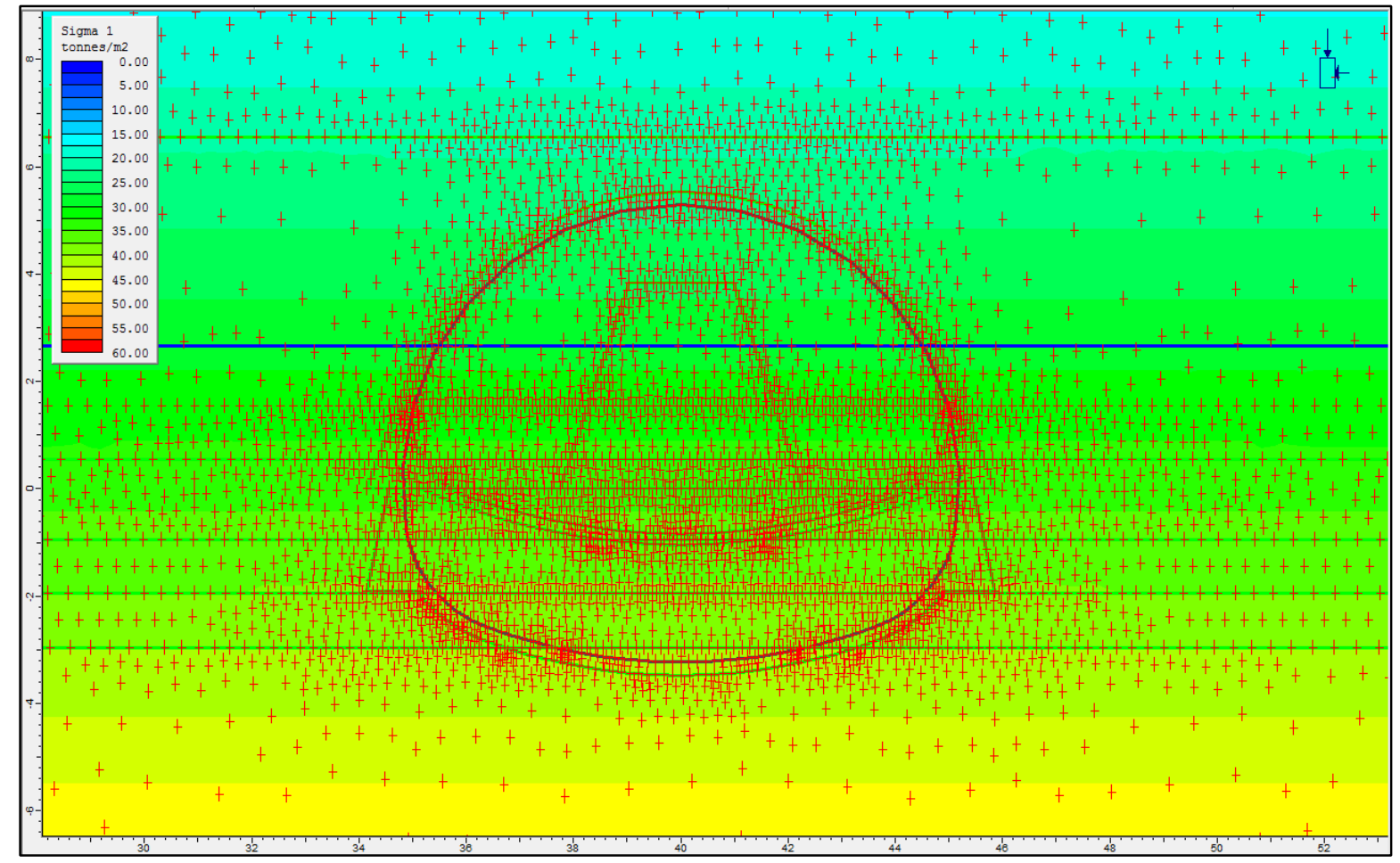

Figura 66 Diagrama de tensões $\left(\sigma_{1}\right)$ com vetores das tensões principais no estado inicial

Com o avanço da frente de escavação e a remoção das tensões existentes no contorno da abertura, ocorrem deslocamentos no maciço e reordenação do estado de tensões em uma nova situação de equilíbrio, alterando a direção das tensões principais, conforme se observa nas figuras a seguir.

Esse novo estado de equilíbrio ocorre em função da solicitação da resistência ao cisalhamento do maciço vizinho à escavação.

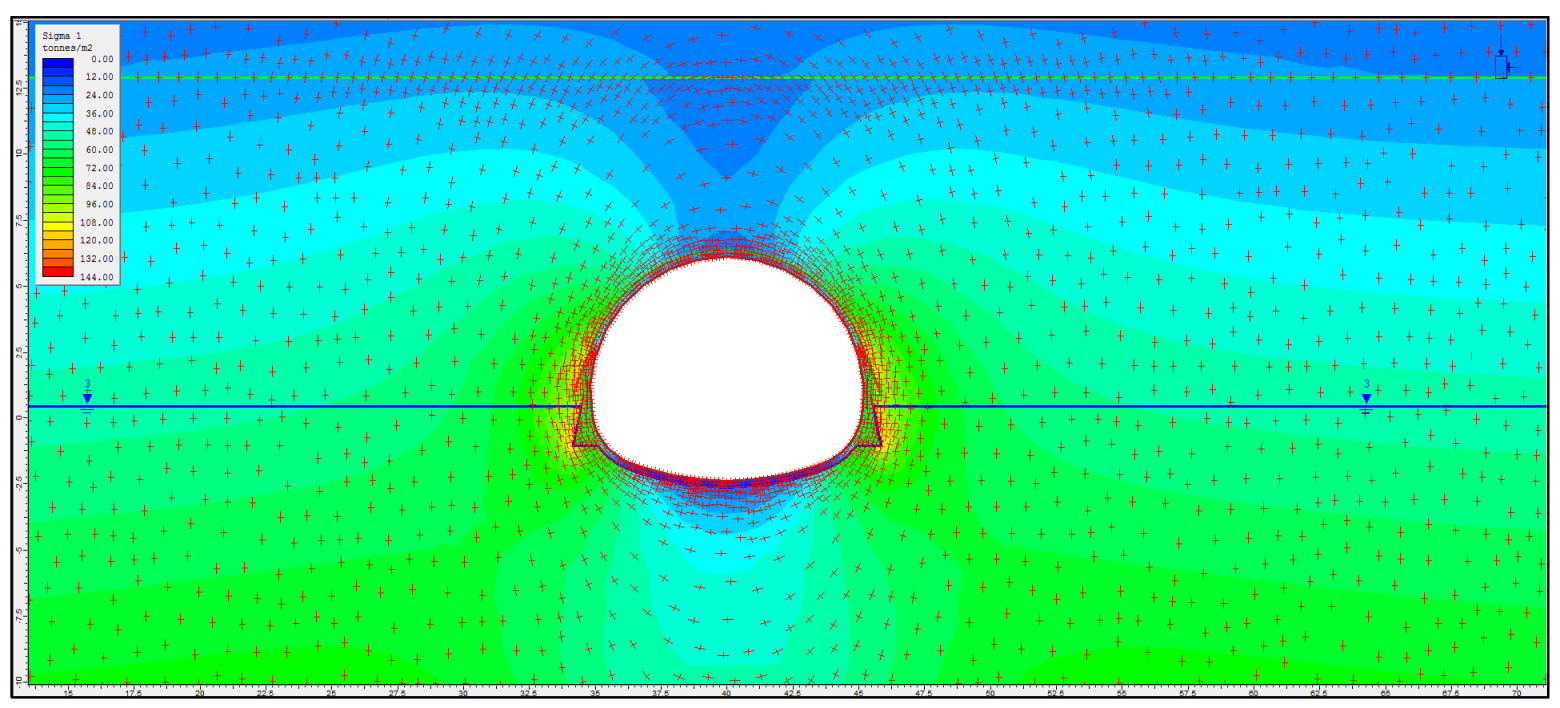

Figura 67 Diagrama de tensões $\left(\sigma_{1}\right)$ com vetores das tensões principais para o Cenário 1 


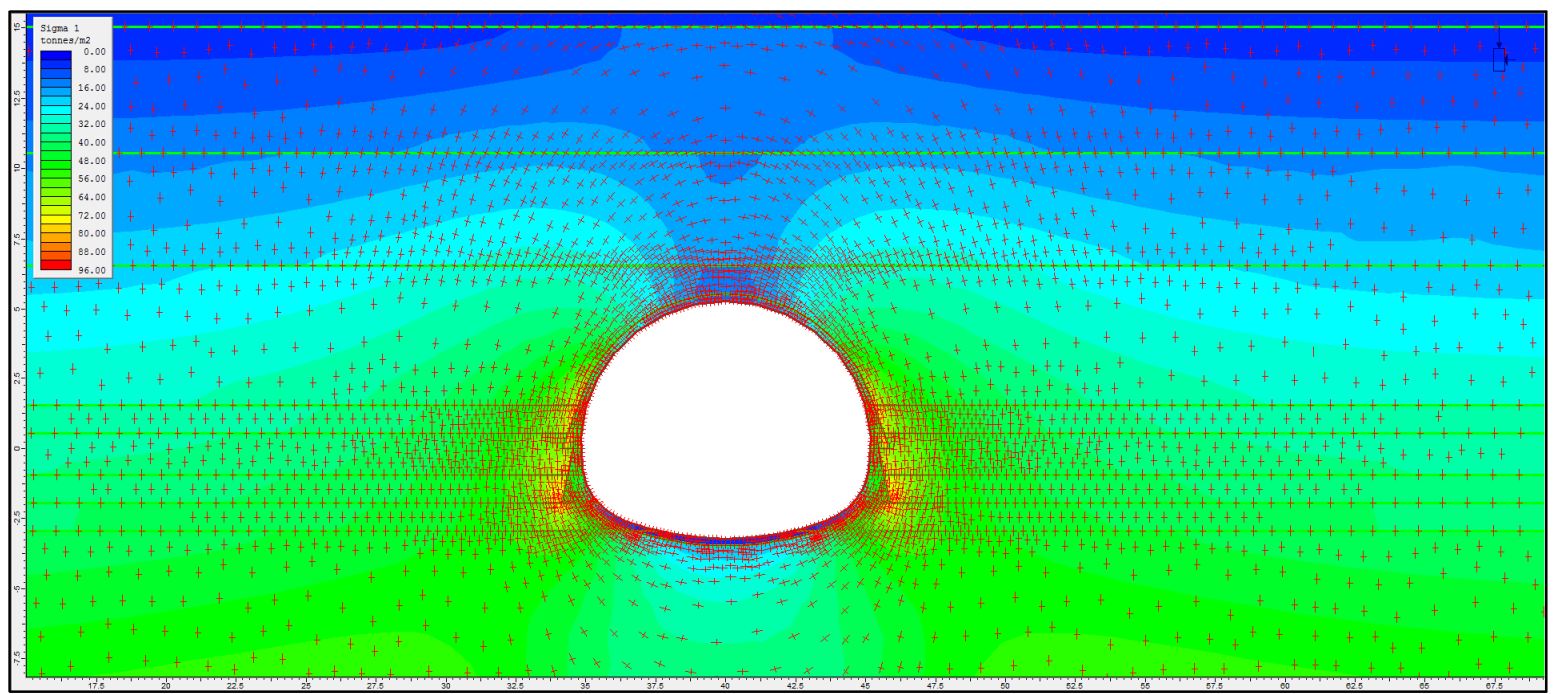

Figura 68 Diagrama de tensões $\left(\sigma_{1}\right)$ com vetores das tensões principais para o Cenário 2

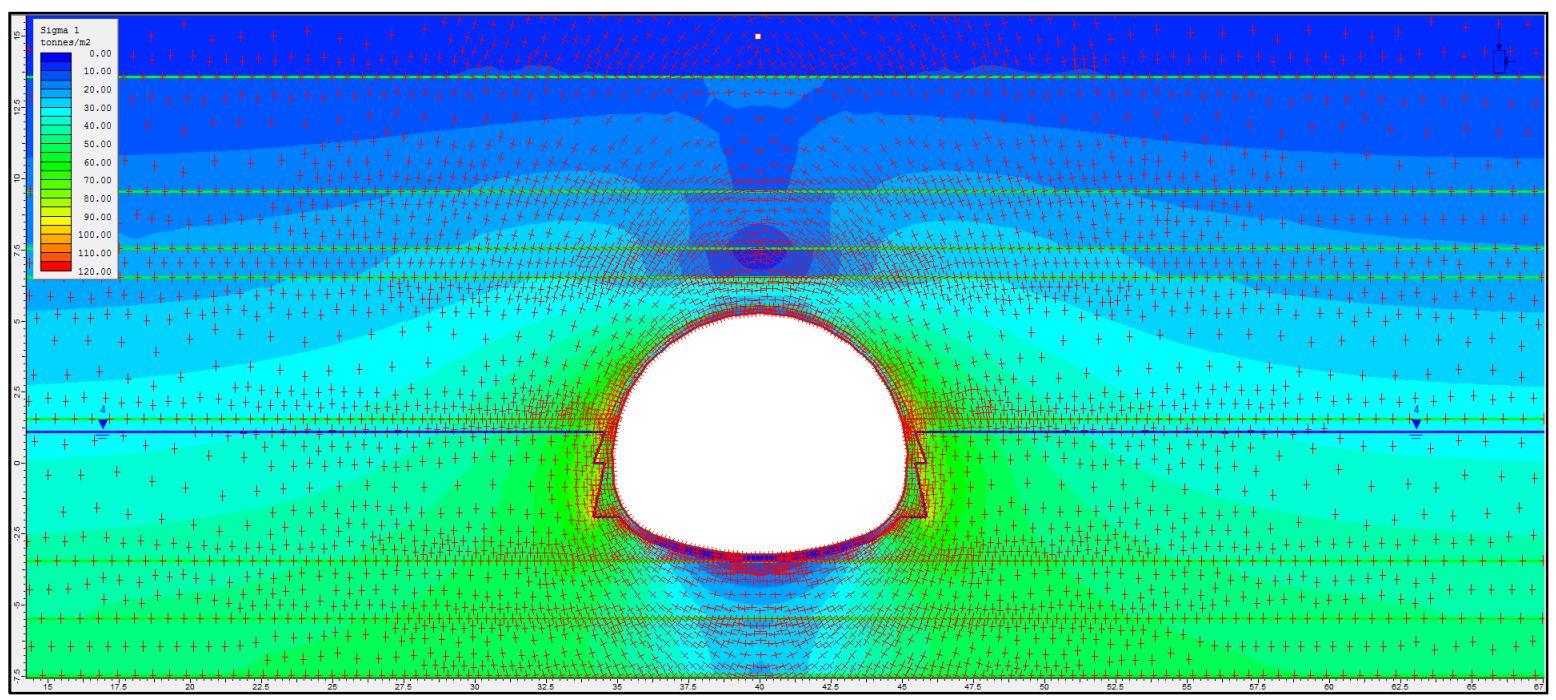

Figura 69 Diagrama de tensões $\left(\sigma_{1}\right)$ com vetores das tensões principais para o Cenário 3 
5.4.5 Análise do caminhamento das cargas na estrutura

\subsubsection{Capacidade de fundação do túnel}

Conforme mencionado, uma vez que o revestimento da calota do túnel esteja concluído, o arco de concreto projetado encontra-se apoiado sobre sapatas, o maciço sob a base da sapata deve ter capacidade de fundação suficiente para suportar os carregamentos atuantes sobre o mesmo.

A capacidade última de fundação de uma sapata corrida pode ser estimada pela expressão proposta por Terzaghi apud Vargas (35):

$$
\sigma_{r}=c \cdot N_{c} \cdot S_{c}+. q \cdot N_{q} \cdot S_{q}+0,5 \cdot \gamma \cdot B \cdot N_{\gamma} \cdot S_{\gamma}
$$

Em que,

$\sigma r$ - capacidade de carga ou tensão de ruptura dos solos $\left(\mathrm{t} t / \mathrm{m}^{2}\right)$;

$c$ - coesão efetiva dos solos $\left(\mathrm{t} f / \mathrm{m}^{2}\right)$;

$\gamma$ - peso específico dos solos $\left(\mathrm{tt} / \mathrm{m}^{3}\right)$;

B - largura da sapata $(\mathrm{m})$;

$q$ - tensão efetiva do solo na cota de apoio da fundação $(q=\gamma h)\left(\mathrm{tf} / \mathrm{m}^{2}\right)$;

$N_{c}, N_{\gamma}, N_{q}$ - fatores de carga obtidos em função do ângulo de atrito do solo na Figura 70;

$S_{c}, S_{\gamma}, S_{q}$ - fatores de forma igual a 1 para sapata corrida.

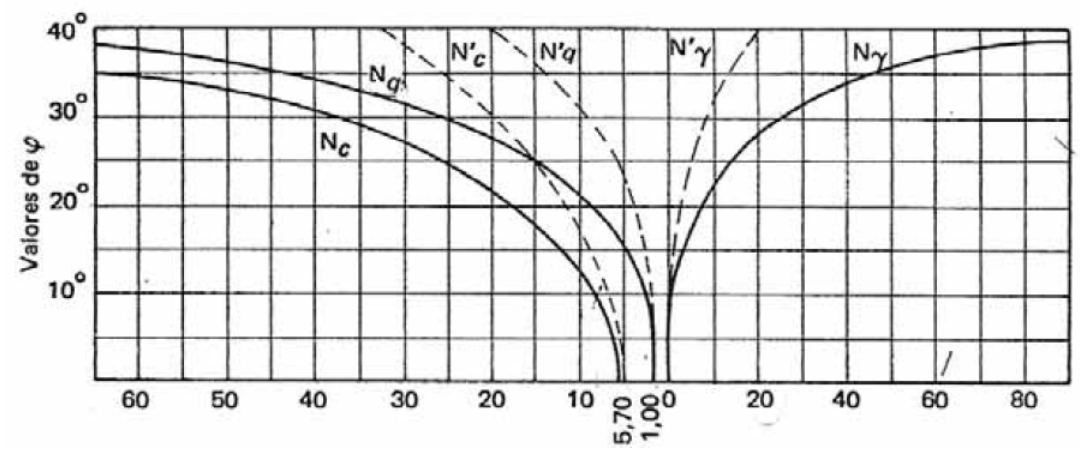

Figura 70 Fatores de capacidade de carga (copiado de Vargas (35)) 
A análise aqui exposta refere-se ao caso de "ruptura global". Para os casos de ruptura local os fatores de capacidade de carga a serem utilizados na determinação da capacidade de carga das fundações diretas pela formulação clássica de Terzaghi devem ser obtidos na Figura 70 nas curvas para $N_{c}{ }^{\prime}, N_{q}{ }^{\prime} \mathrm{e} N_{\gamma}$ '.

Obtêm-se as seguintes capacidades de fundação de cada cenário e os respectivos coeficientes de segurança (FS):

\begin{tabular}{|c|c|c|c|c|c|c|c|c|c|}
\hline & $\mathrm{c}$ & $N_{c}$ & $\mathrm{q}$ & $N_{q}$ & $\mathrm{~B}$ & $N_{\gamma}$ & $\sigma r$ & $\sigma$ atuante & $\mathrm{FS}$ \\
\cline { 2 - 10 } & $\left(\mathrm{tf} / \mathrm{m}^{2}\right)$ & & $\left(\mathrm{tf} / \mathrm{m}^{2}\right)$ & & $(\mathrm{m})$ & & $\left(\mathrm{tf} / \mathrm{m}^{2}\right)$ & $\left(\mathrm{tf} / \mathrm{m}^{2}\right)$ & \\
\hline Cenário 1 & 2 & 37,5 & 48,36 & 25 & 0,65 & 22,5 & 1298,62 & 154,65 & 8,40 \\
\hline Cenário 2 & 7,5 & 18 & 31,46 & 9 & 0,65 & 8 & 423,08 & 88,03 & 4,81 \\
\hline Cenário 3 & 7,5 & 18 & 34,67 & 9 & 0,65 & 8 & 451,97 & 98,04 & 4,61 \\
\hline
\end{tabular}

Tabela 8 - Capacidades de fundação das sapatas e fatores de segurança

Uma vez que o fator de segurança para fundações provisórias deve ser superior a 1,5 , conclui-se que o equilíbrio perante o carregamento sobre a calota do túnel está garantido. Nota-se que em função da cobertura e do solo de fundação, o fator de segurança no cenário 1 é muito superior aos dos outros cenários.

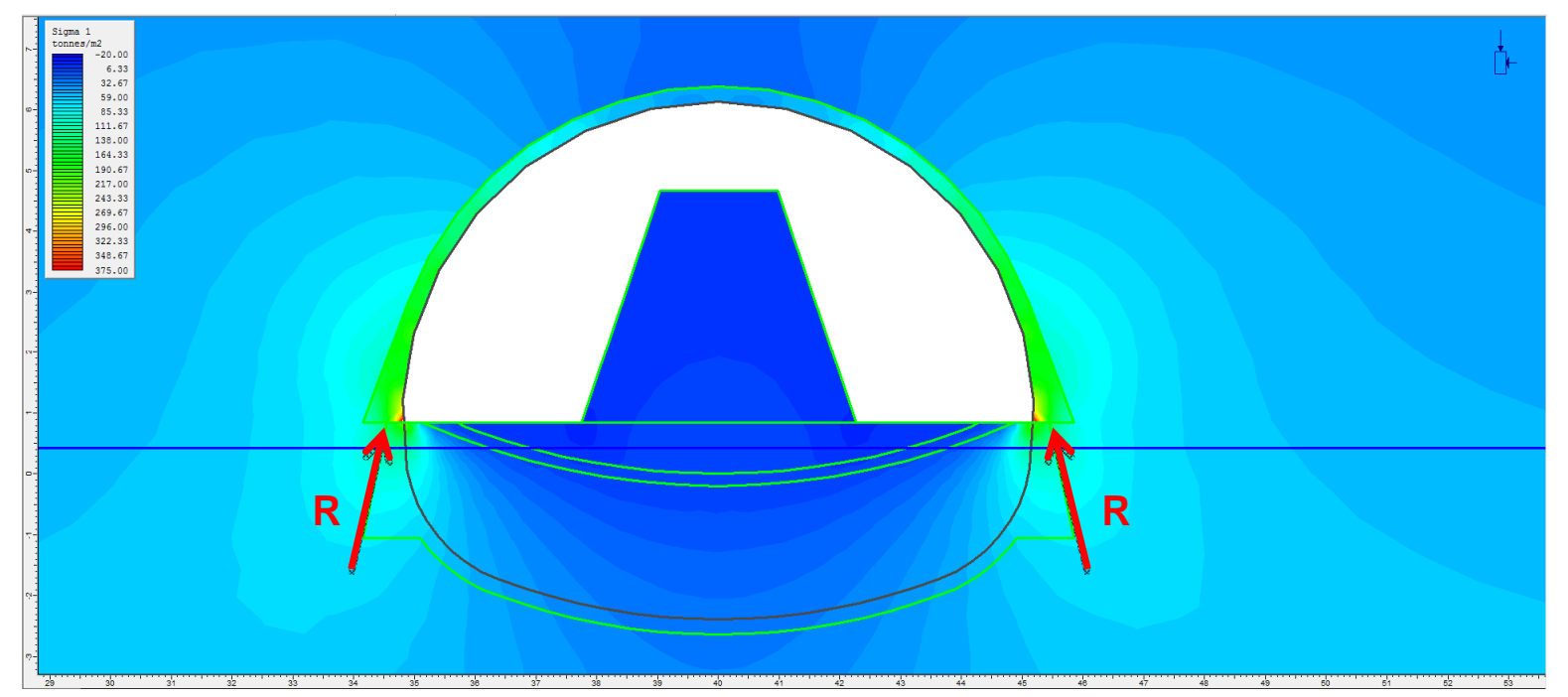

Figura 71 Diagrama das tensões na fundação da calota, com vetores da reação $(R)$ do solo para o Cenário 1 


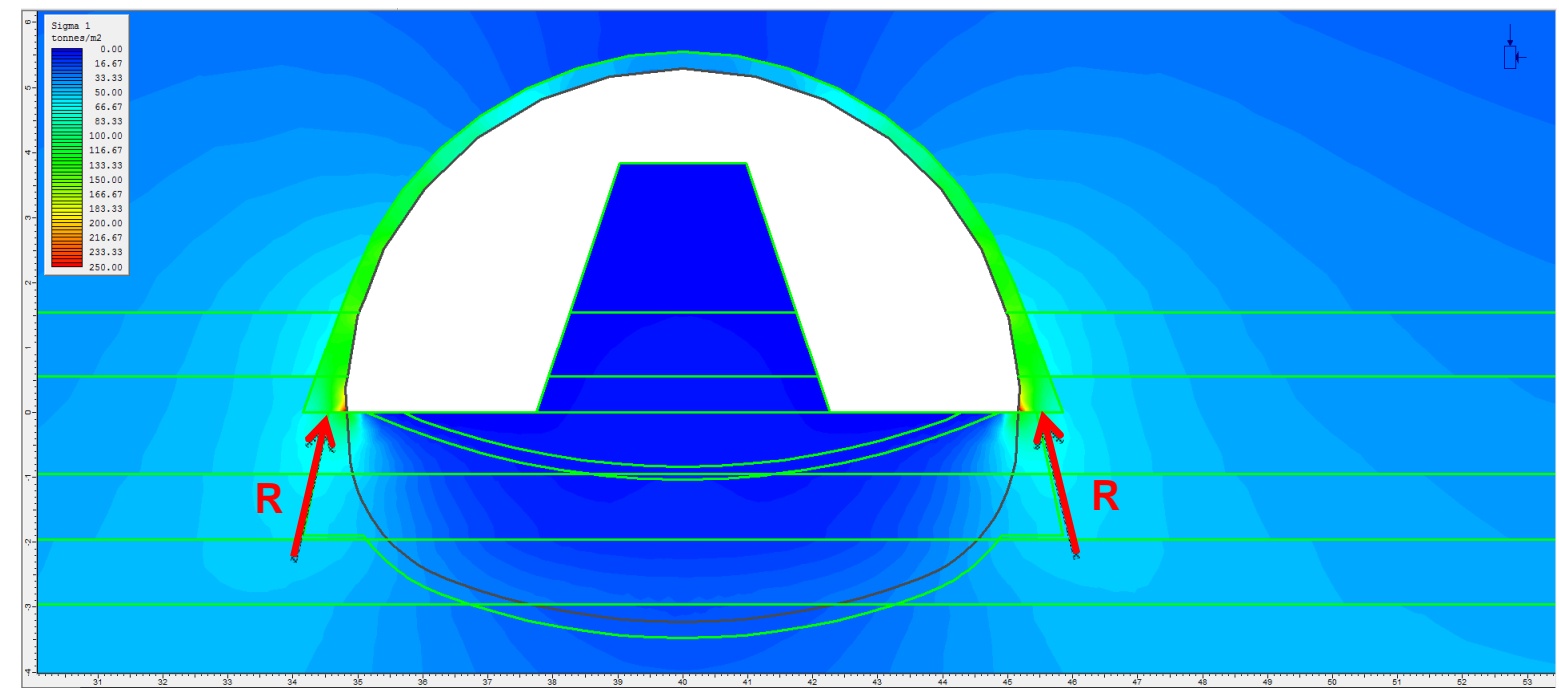

Figura 72 Diagrama das tensões na fundação da calota, com vetores da reação $(R)$ do solo para o Cenário 2

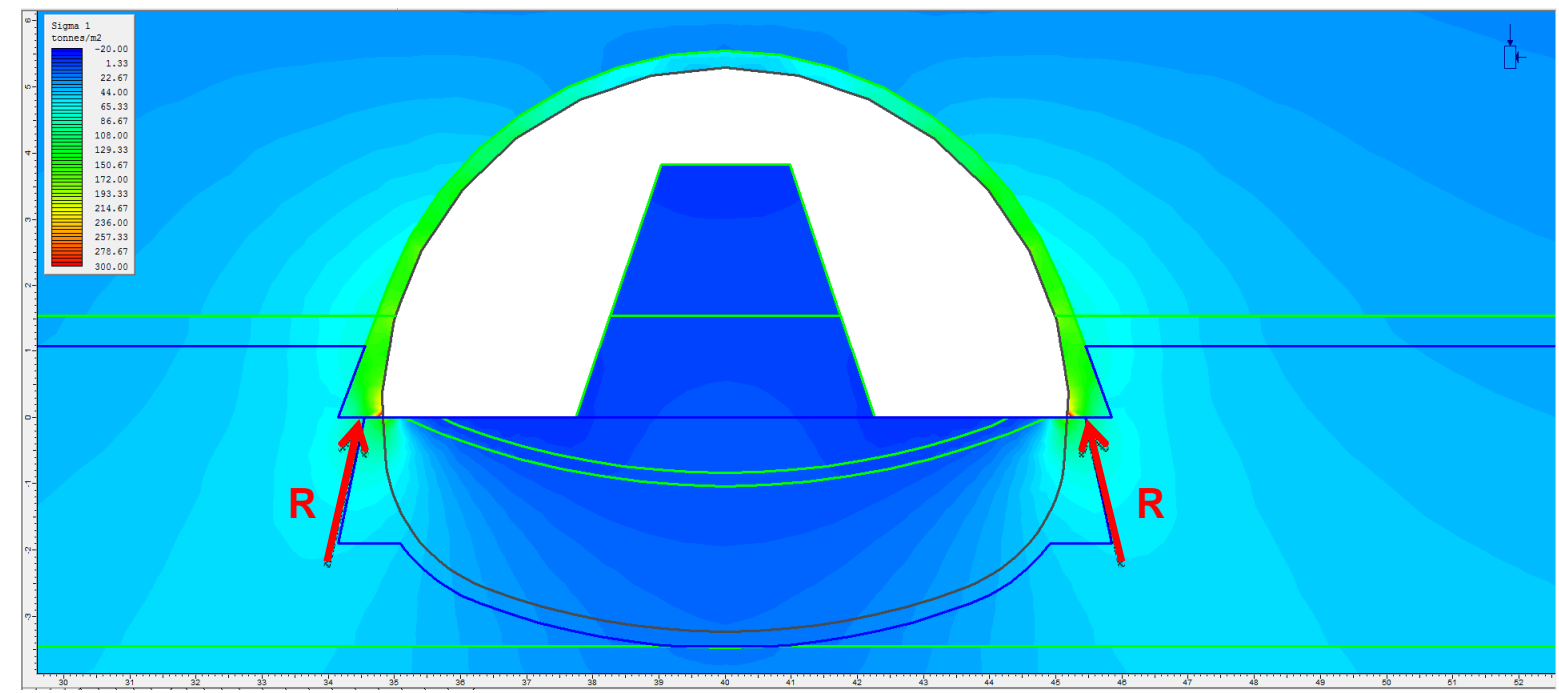

Figura 73 Diagrama das tensões na fundação da calota, com vetores da reação $(R)$ do solo para o Cenário 3

\subsubsection{Tensões no AIP (Arco Invertido Provisório)}

As análises das tensões no AIP apresentadas neste subitem são qualitativas e referem-se à Fase 13 das modelagens numéricas. Fase em que o revestimento de concreto projetado do AIP encontra-se com 100\% progressivo do Módulo de Elasticidade. 


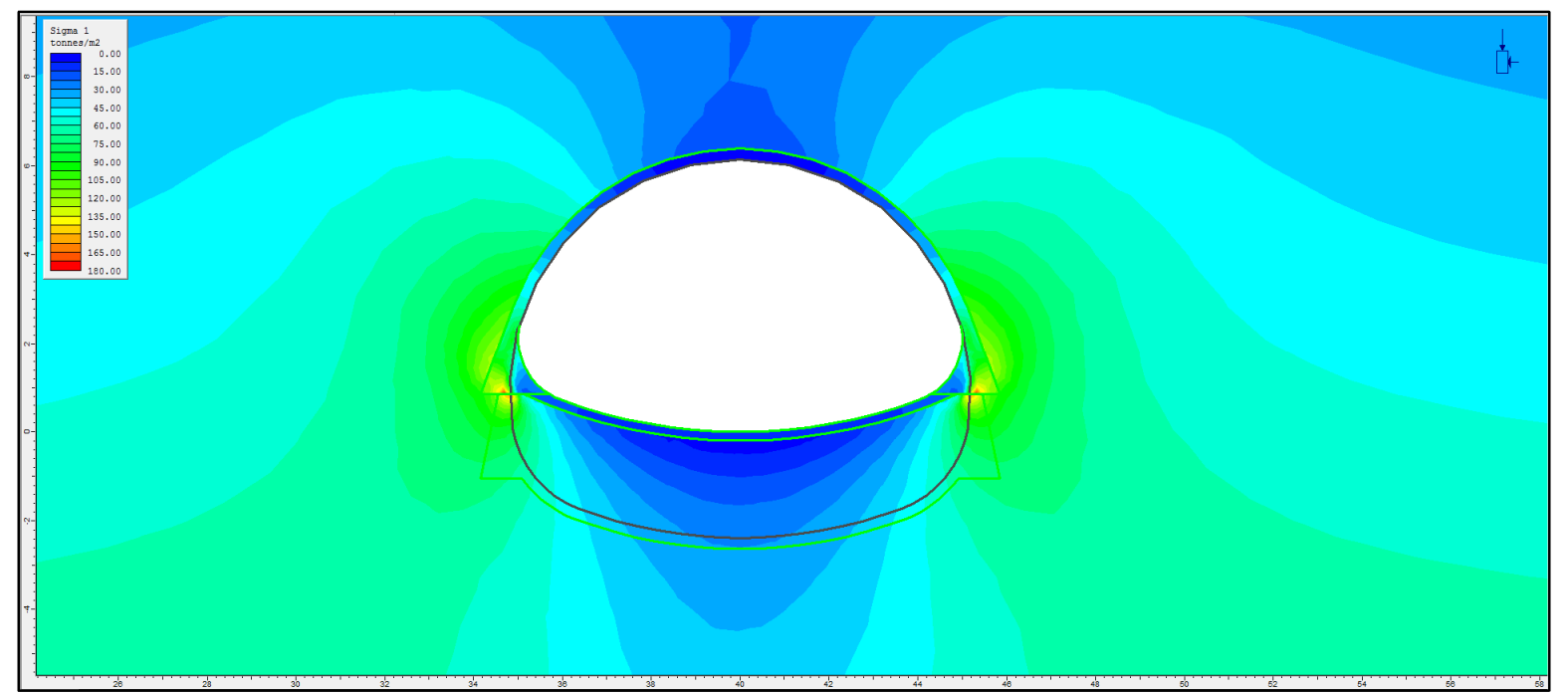

Figura 74 Diagrama das tensões no AIP - Cenário 1

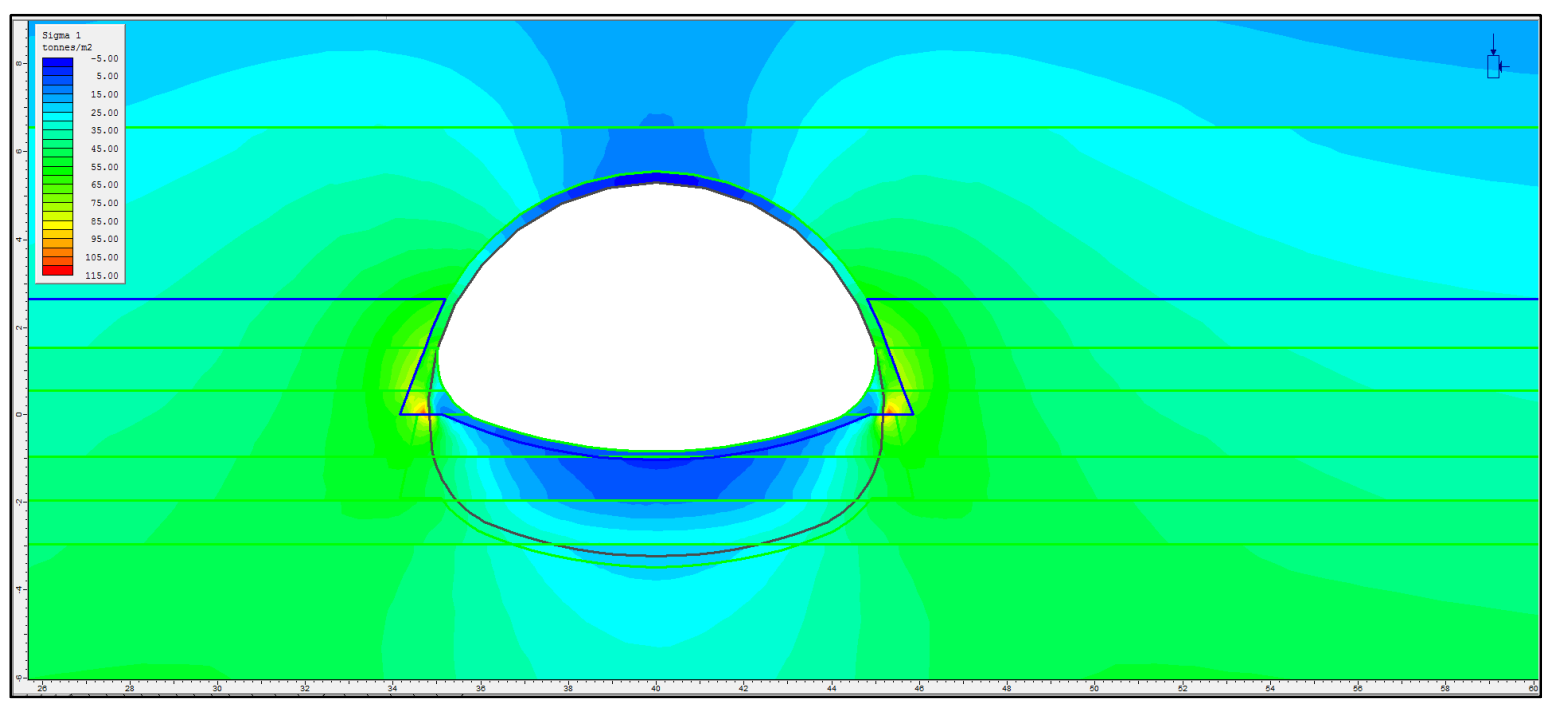

Figura 75 Diagrama das tensões no AIP - Cenário 2

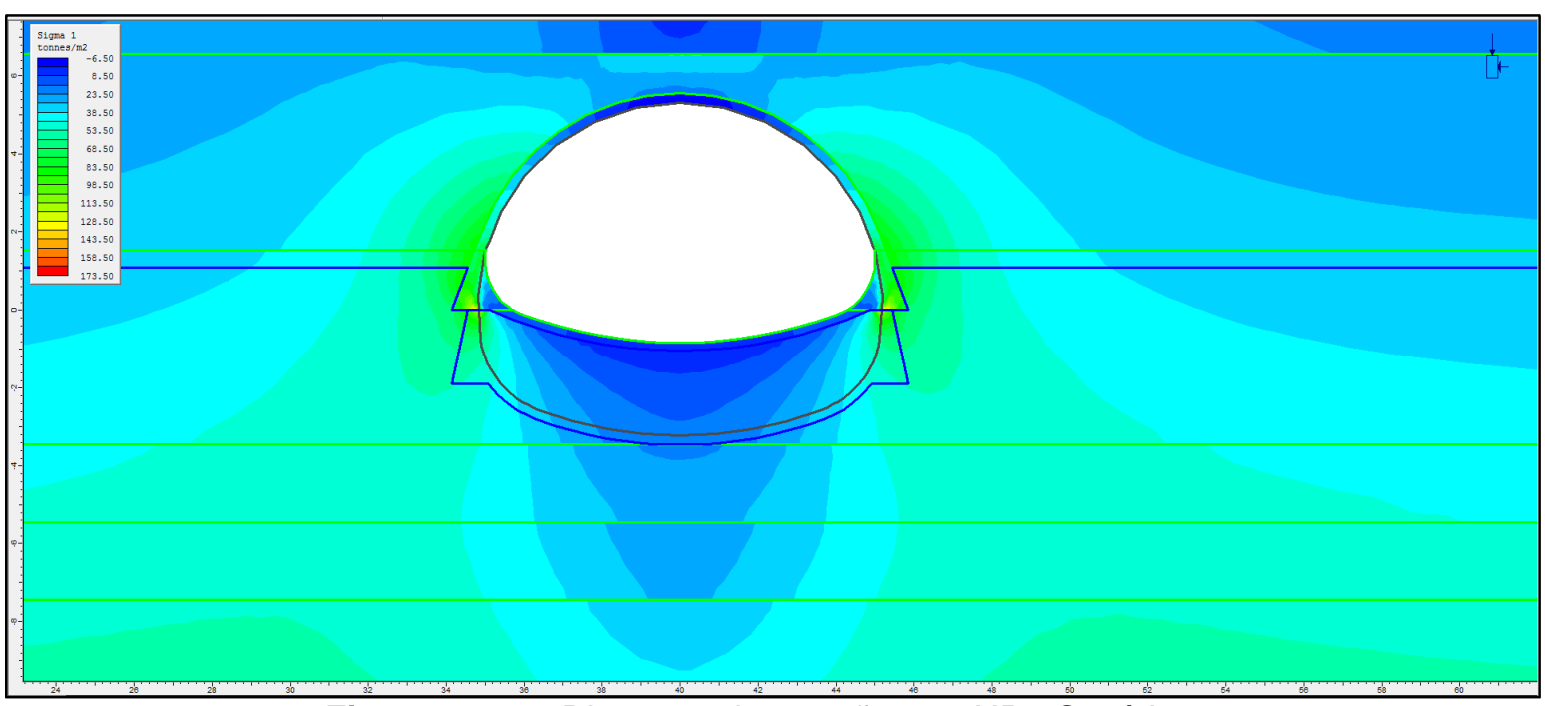

Figura 76 Diagrama das tensões no AIP - Cenário 3 
Ao analisar os diagramas de tensões $\sigma 1$, observa-se que nos cenários 1 e 3 , nos quais o AIP está apoiado em camadas de 5SR1 e 3Ag1, respectivamente, as tensões no maciço concentram-se próximo às sapatas, diminuindo rapidamente na direção do eixo do túnel. No entanto, no cenário 2, no qual o maciço sob o AIP é constituído de camadas alternadas de 3Ag1, 3Ar1 e 4Ag3, as tensões diminuem lentamente na direção do eixo do túnel. Isso indica que nos cenários 1 e 3 o solo da fundação das sapatas tem boa capacidade de suportar os esforços, e no cenário 20 solo da fundação é menos competente, e, nesse caso, o AIP é muito mais importante. Apesar do fator de segurança da sapata, calculado por meio da forma de Terzaghi, ser semelhante ao do cenário 3. Isso ocorre, pois Terzaghi não considera a estratigrafia do subsolo sob a sapata.

\subsubsection{Tensões no AID (Arco Invertido Definitivo)}

As análises das tensões no AID apresentadas neste subitem são qualitativas e referem-se à Fase 19 das modelagens numéricas. Fase em que o revestimento de concreto projetado do AID encontra-se com 100\% progressivo do Módulo de Elasticidade.

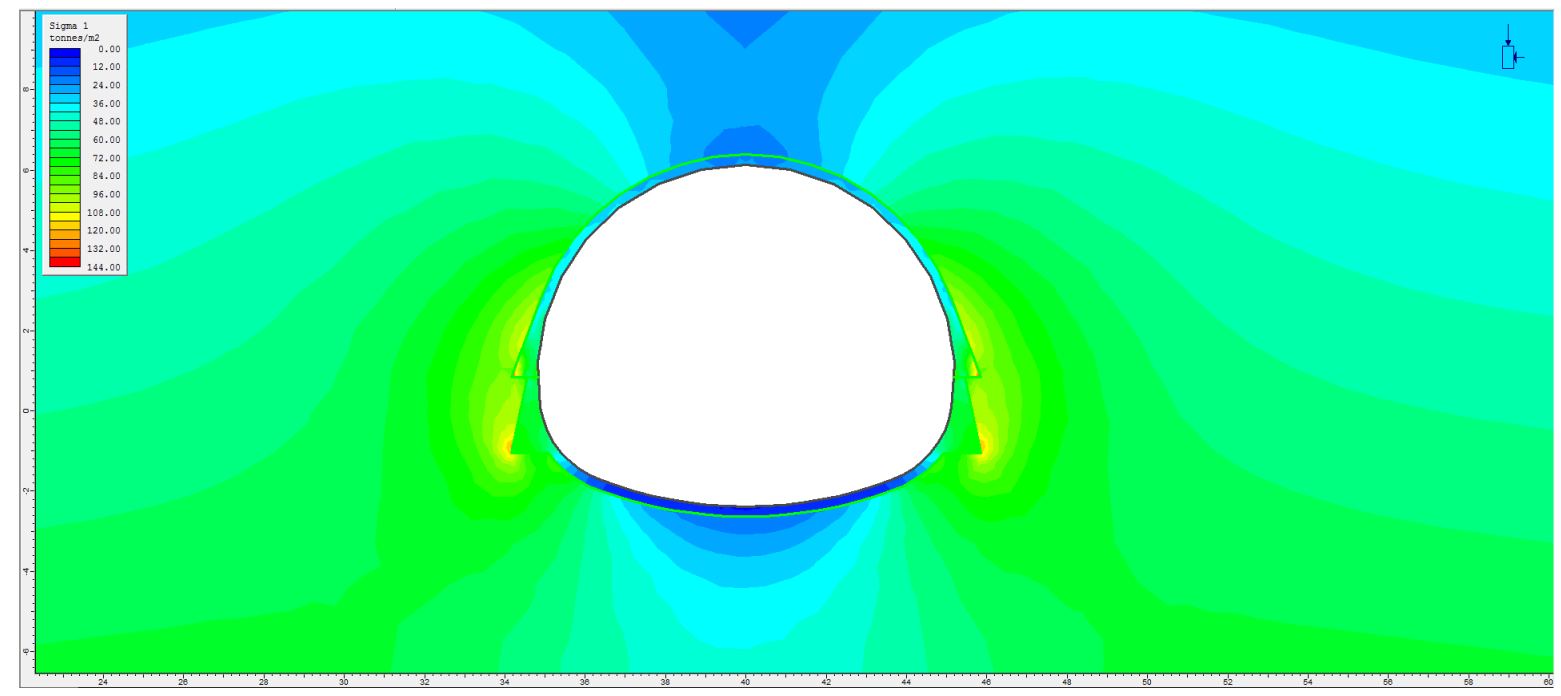

Figura 77 Diagrama das tensões no AID - Cenário 1 


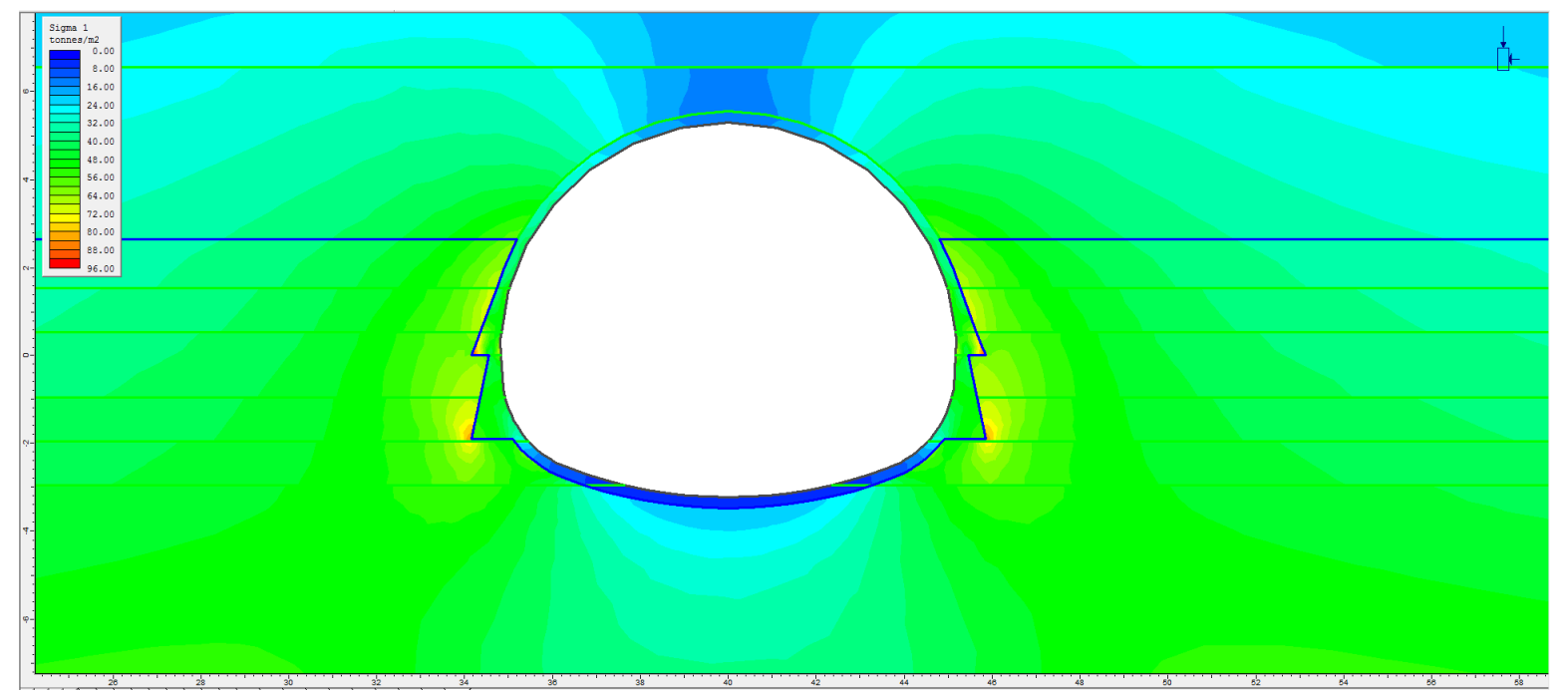

Figura 78 Diagrama das tensões no AID - Cenário 2

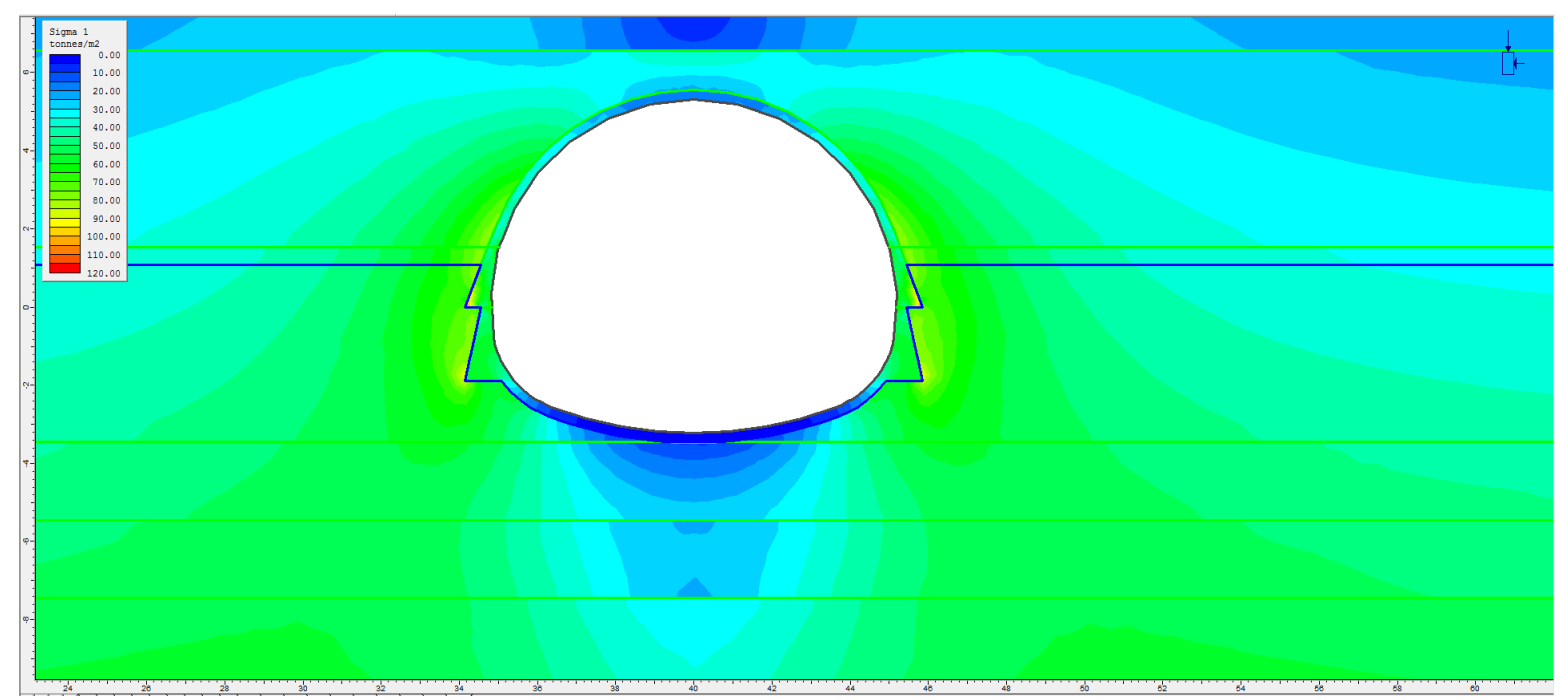

Figura 79 Diagrama das tensões no AID - Cenário 3

De modo semelhante ao analisado no AIP, com as tensões no maciço sob o AID do cenário 1 e 3, concentram-se sob as sapatas e nos trechos de menor raio. Já no cenário 2 as tensões são quase constantes, só reduzindo próximo ao eixo do túnel. Neste último caso, em função da capacidade do solo de fundação, é necessária uma área de reação maior para equilibrar os esforços.

\subsubsection{Tensões nas juntas}

A seguir são apresentados os diagramas de deformação máxima por cisalhamento na região das juntas de concretagem entre a calota e o AIP. 


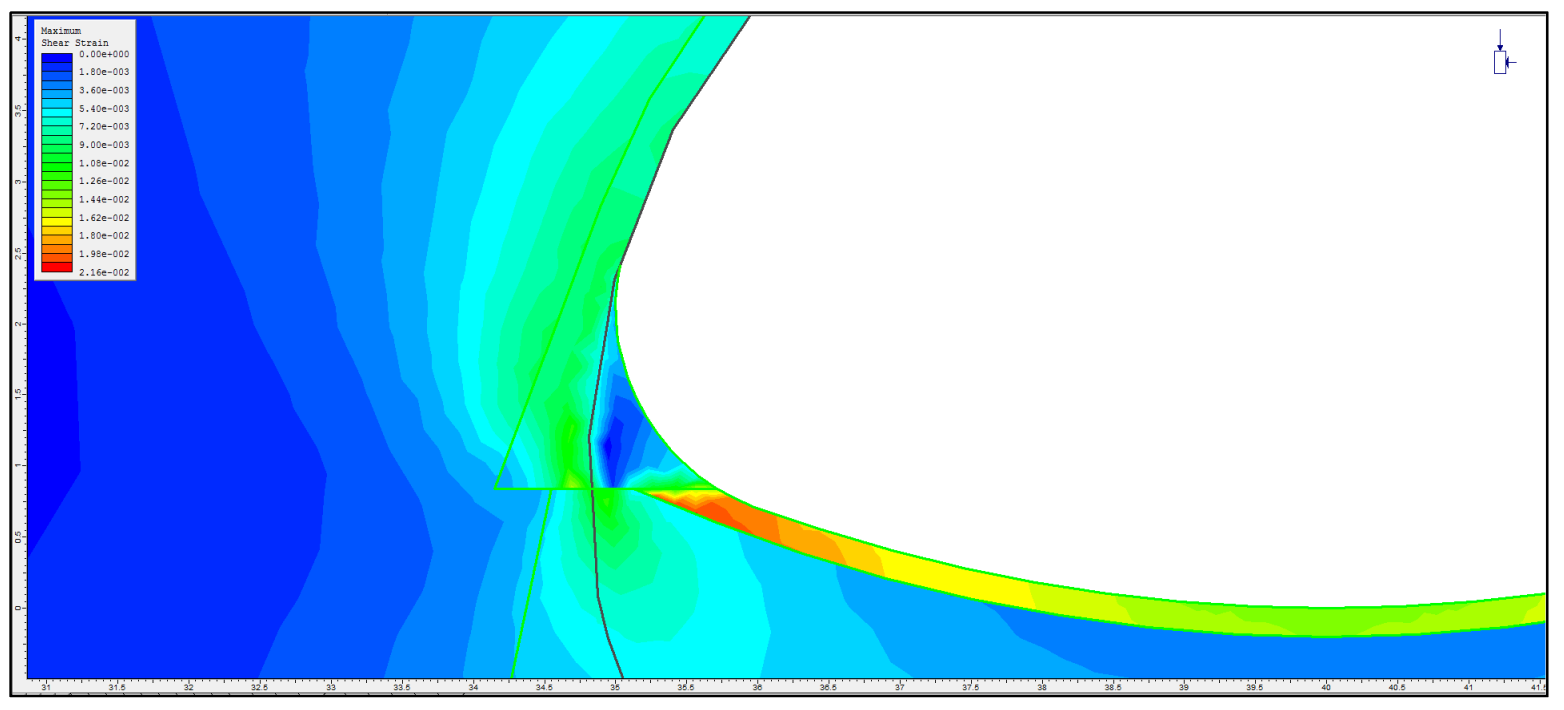

Figura 80 Diagrama de deformação por cisalhamento na junta entre o revestimento do AIP e da calota - Cenário 1

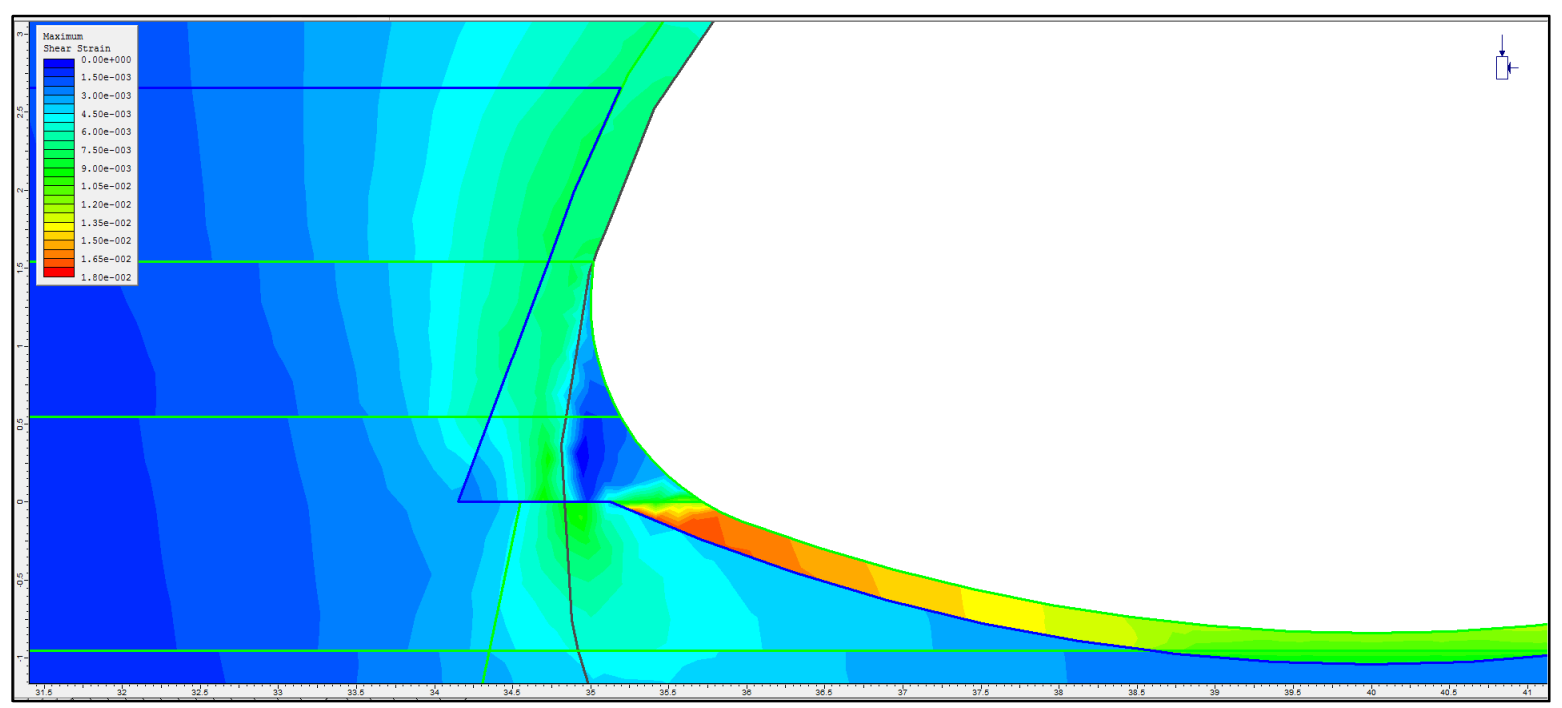

Figura 81 Diagrama de deformação por cisalhamento na junta entre o revestimento do AIP e da calota - Cenário 2 


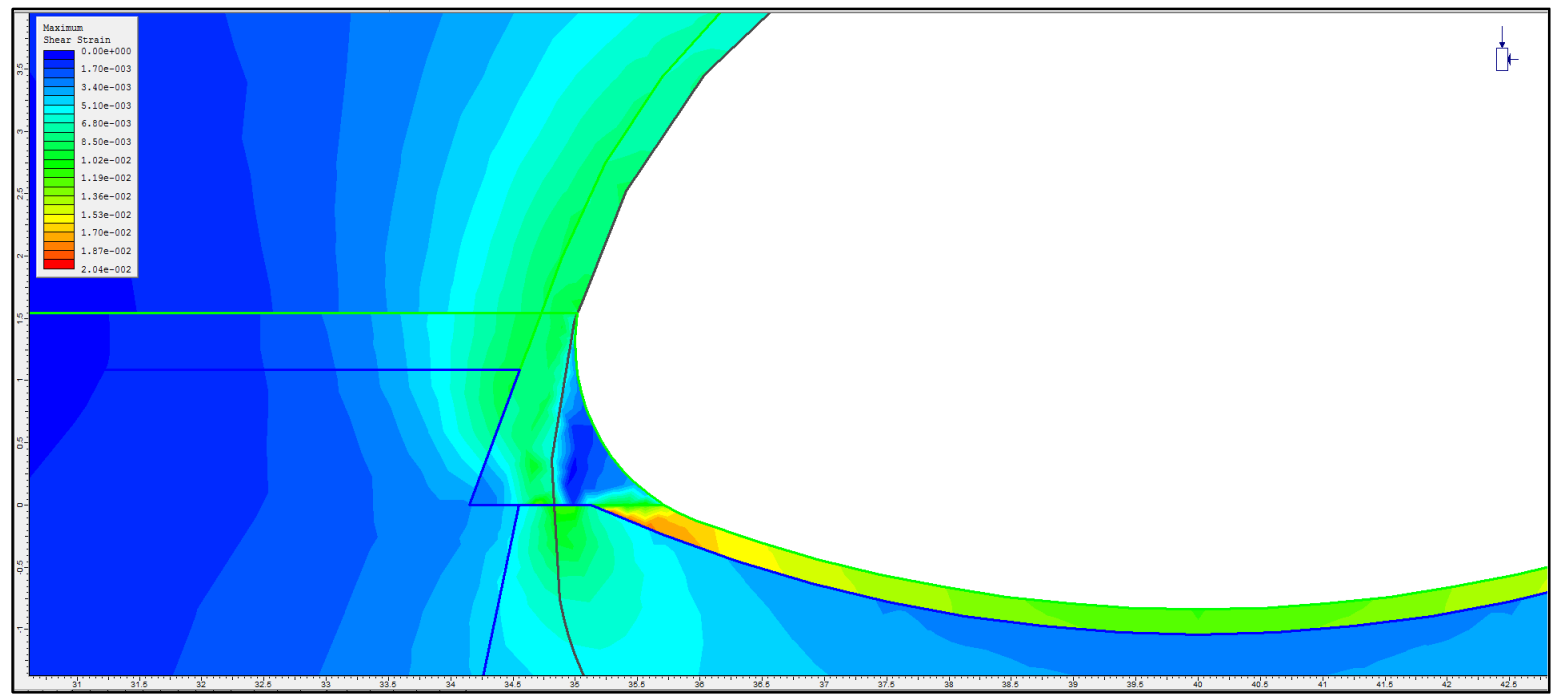

Figura 82 Diagrama de deformação por cisalhamento na junta entre o revestimento do AIP e da calota - Cenário 3

Conforme se pode observar nas figuras, em função da geometria adotada para as juntas de concretagem, estas não são capazes de equilibrar os esforços somente por meio de força normal, surgindo tensões de cisalhamento no revestimento.

De acordo com o exposto nos itens anteriores, há uma concentração de tensões no maciço sob as sapatas. Essa concentração de tensões resulta em deslocamentos (recalques) nas sapatas, maiores que os deslocamentos observados no AIP. Essa diferença de deslocamentos ocasiona as tensões de cisalhamento observadas nos diagramas apresentados. No cenário 2 as tensões de cisalhamento são mais atuantes nas juntas de concretagem, em função da capacidade de carga do solo de fundação e dos consequentes deslocamentos.

$\mathrm{Na}$ obra em questão, o revestimento, mesmo sem armação, foi suficiente para equilibrar os esforços, sem a ocorrência de ruptura por cisalhamento. 


\section{COMPARAÇÃO COM OS DADOS OBTIDOS EM CAMPO}

A escavação de túneis em solo, inevitavelmente e indubitavelmente, ocasiona movimentos no maciço envolvente e pode resultar em danos nas estruturas e infraestruturas situadas nas proximidades das obras.

Duas origens diferentes podem ser identificadas para esses deslocamentos. A primeira está associada a fenômenos como o adensamento e a compressão causados pela redução da pressão neutra e consequente aumento da tensão efetiva (o rebaixamento do nível freático, por exemplo), sendo mais importante para solos argilosos e ocorrendo de forma diferenciada no tempo. A segunda origem dos deslocamentos está associada ao movimento do solo para o vazio criado pela escavação do túnel.

Em função da complexidade de se modelar o rebaixamento do nível freático, optouse por calcular os cenários com os níveis freáticos após a instalação do sistema de rebaixamento. Portanto, neste item serão analisados somente deslocamentos provenientes da escavação do túnel.

Nesta seção são apresentadas comparações entre os resultados obtidos com a análise numérica realizada e os dados medidos em campo, por meio da instrumentação instalada. Em função da metodologia construtiva empregada, os dados da instrumentação interna do túnel, convergência/divergência e nivelamento interno, apresentam um período de leituras muito exíguo, dificultando as análises. As leituras iniciam-se após a execução da calota e AIP e são concluídas após a execução do AID, com a consequente instalação do revestimento secundário. Portanto, nas análises realizadas neste capítulo, são utilizados os dados de leituras externas: Marcos Superficiais e Tassômetros.

Os gráficos abaixo ilustram as bacias de recalques superficiais, após a execução da calota, obtidas por meio da análise numérica e da instrumentação da obra.

Os perfis de deslocamentos, obtidos por meio da instrumentação da obra, apresentados nos gráficos a seguir, são extrapolações simplistas dos pontos instrumentados. Para efeito comparativo e pela ausência de dados fidedignos, foram adotados os mesmos valores da modelagem numérica para as extremidades das curvas. 


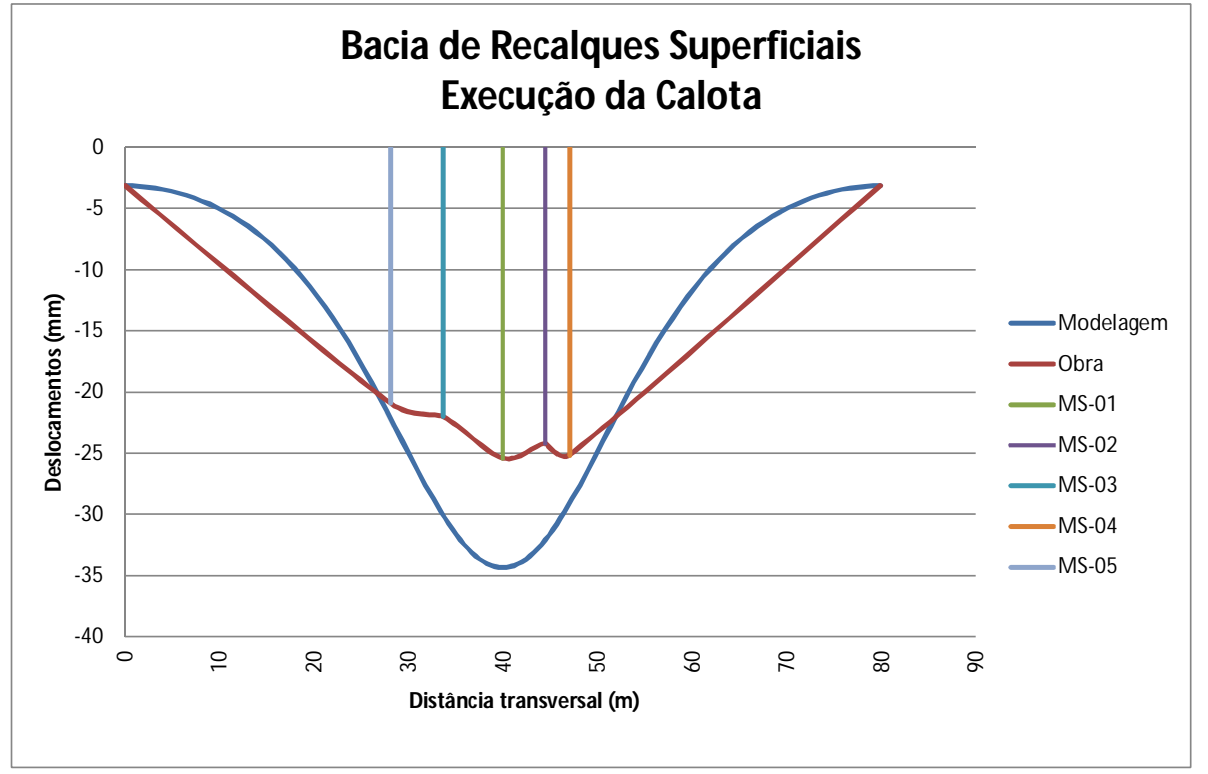

Figura 83 Bacia de recalques superficiais - Calota: análise numérica x obra - Cenário 1

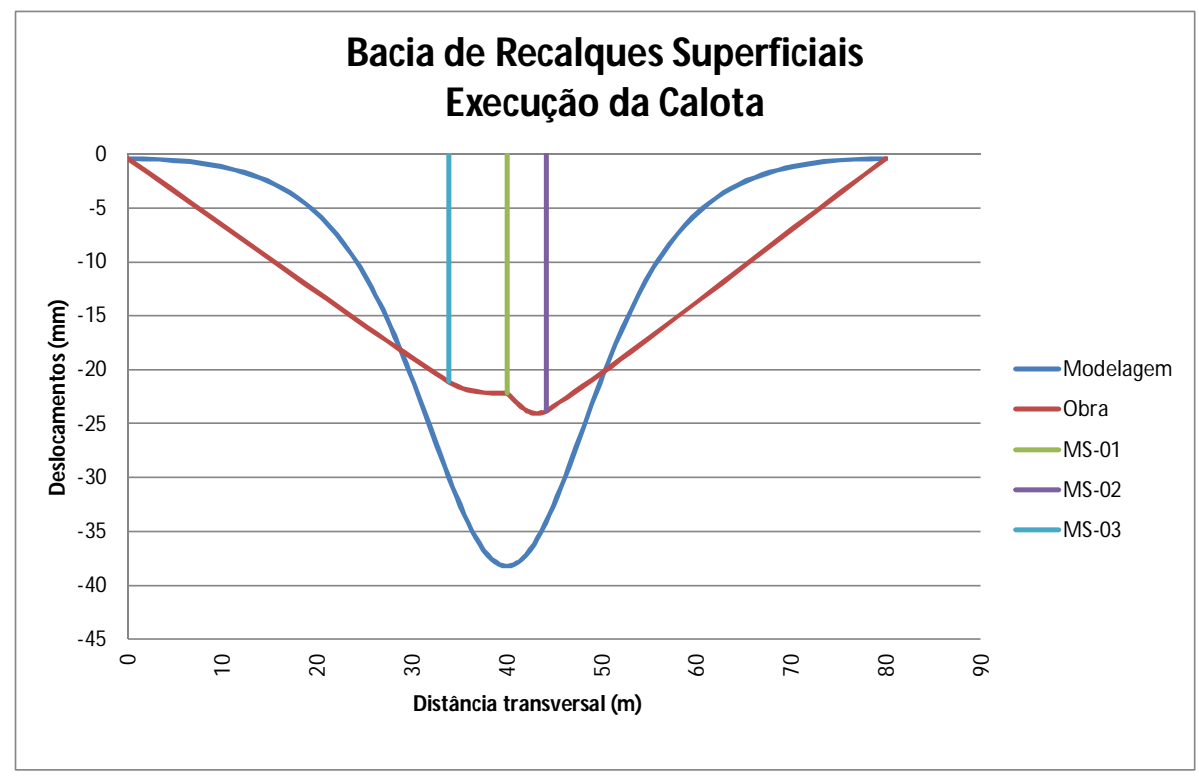

Figura 84 Bacia de recalques superficiais - Calota: análise numérica x obra - Cenário 2 


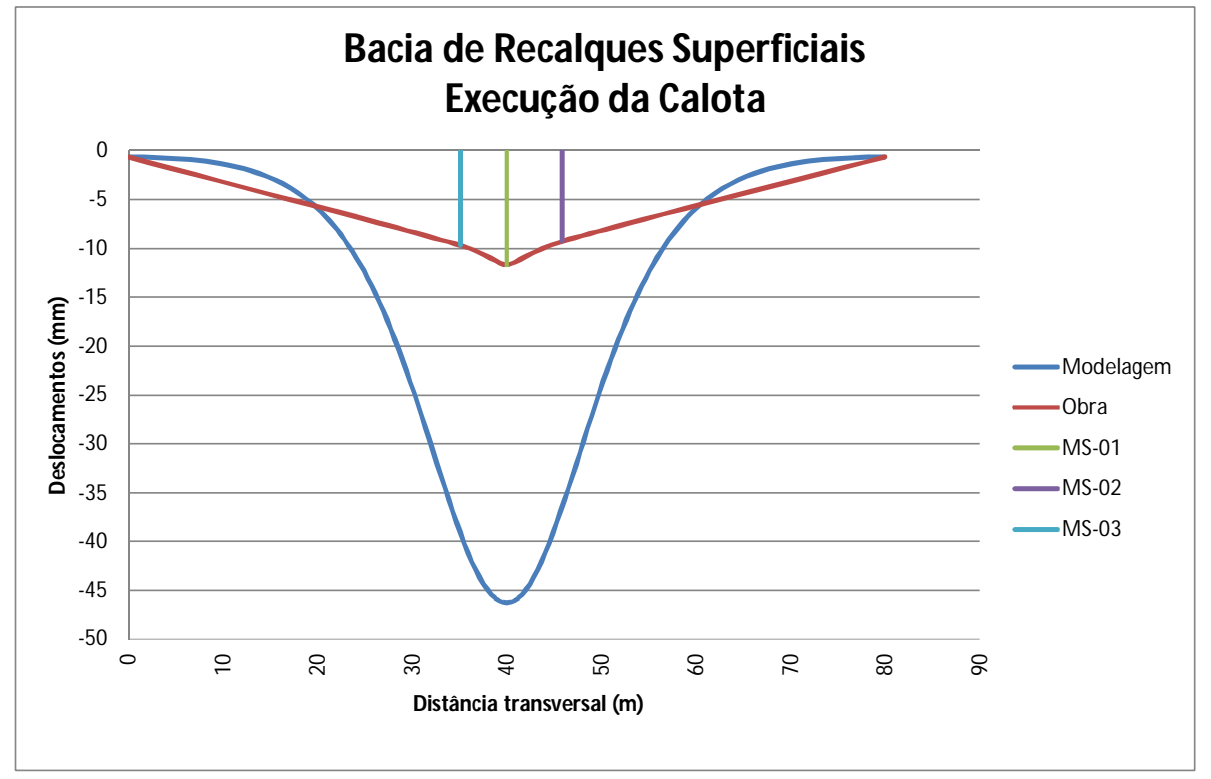

Figura 85 Bacia de recalques superficiais - Calota: análise numérica x obra - Cenário 3

Os gráficos abaixo ilustram as bacias de recalques superficiais, após a execução do AIP, obtidas por meio da análise numérica e da instrumentação da obra.

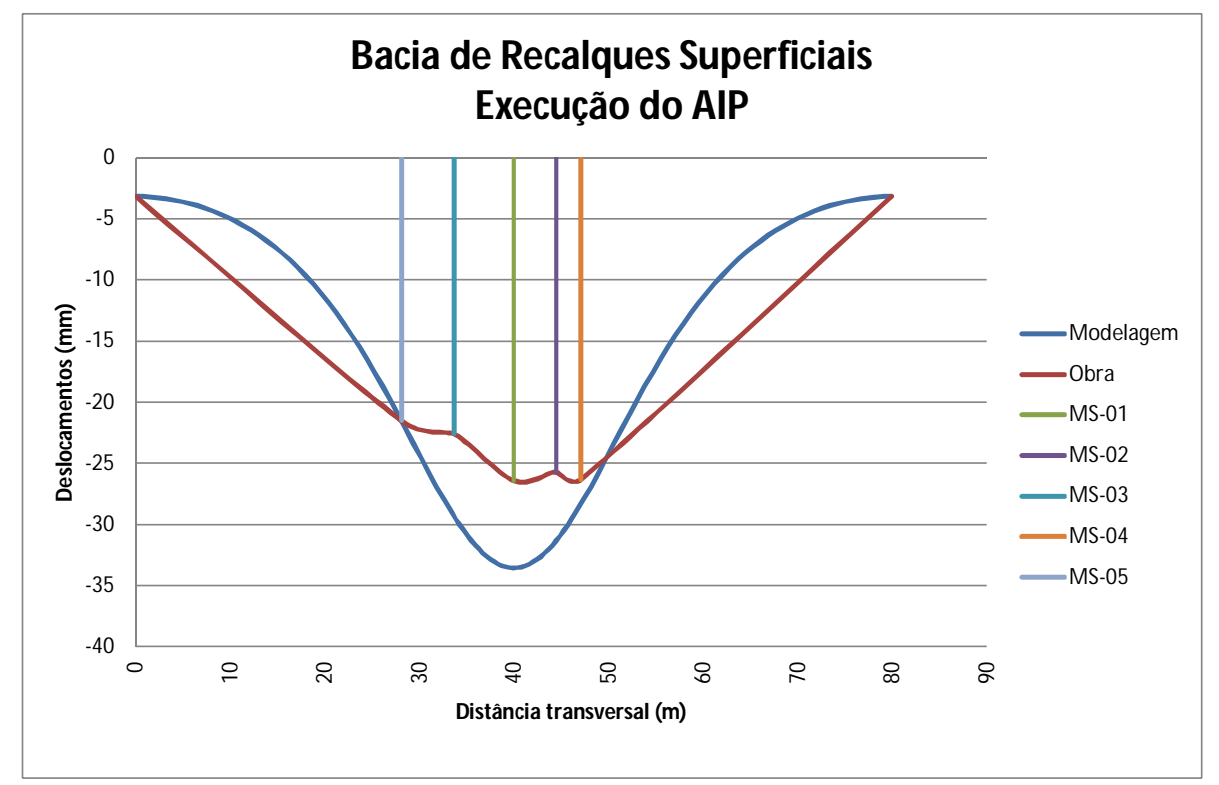

Figura 86 Bacia de recalques superficiais - AIP: análise numérica x obra - Cenário 1 


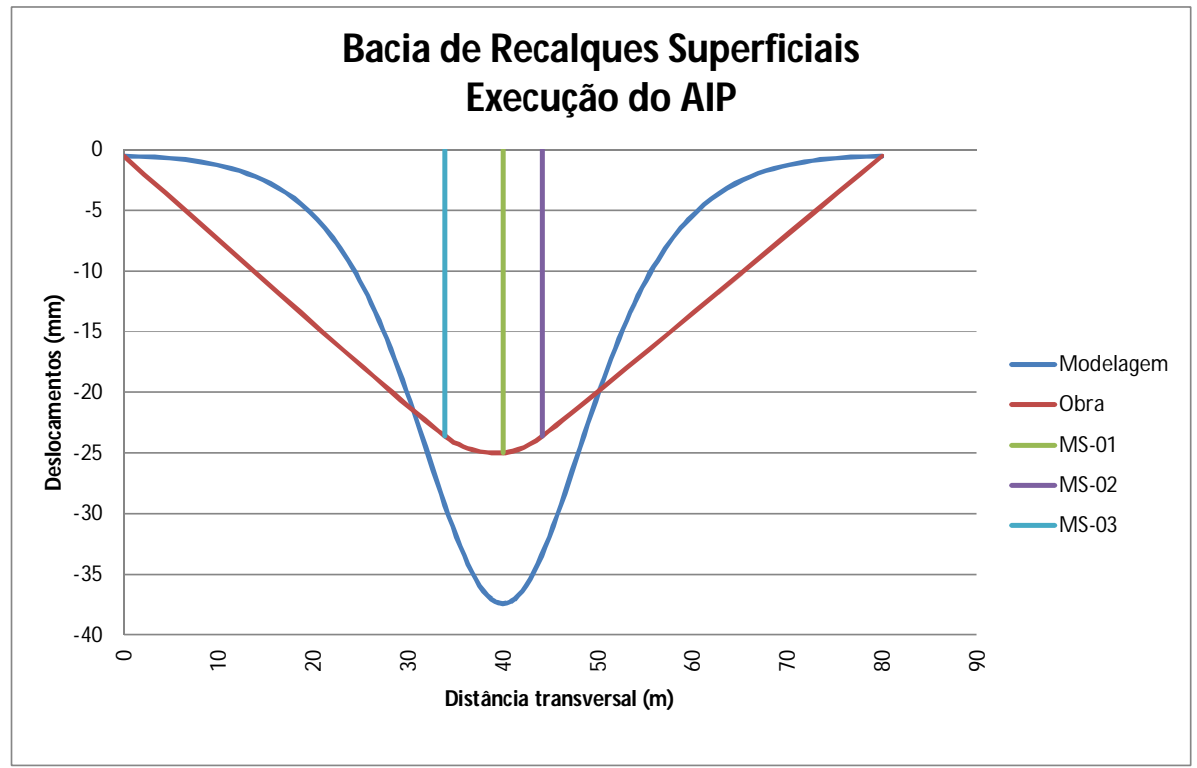

Figura 87 Bacia de recalques superficiais - AIP: análise numérica x obra - Cenário 2

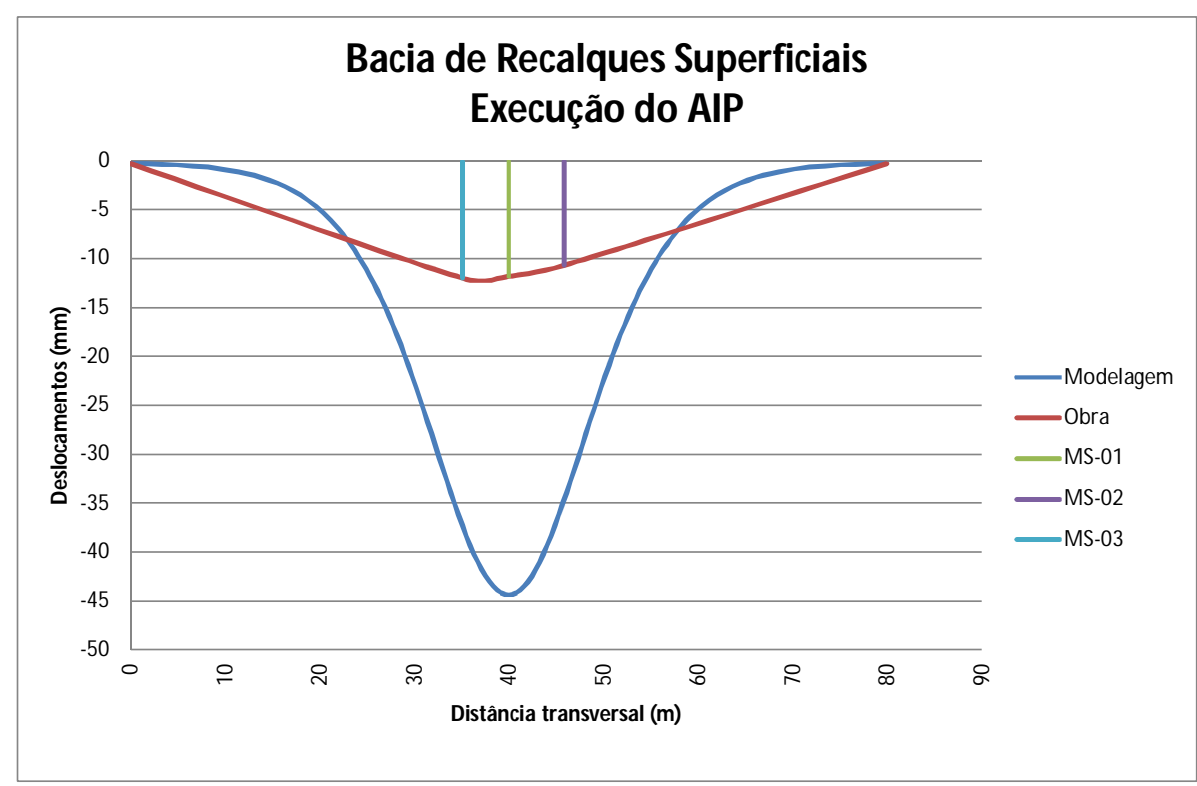

Figura 88 Bacia de recalques superficiais - AIP: análise numérica x obra - Cenário 3

Os gráficos abaixo ilustram as bacias de recalques superficiais, após a execução do AID, obtidas por meio da análise numérica e da instrumentação da obra. 


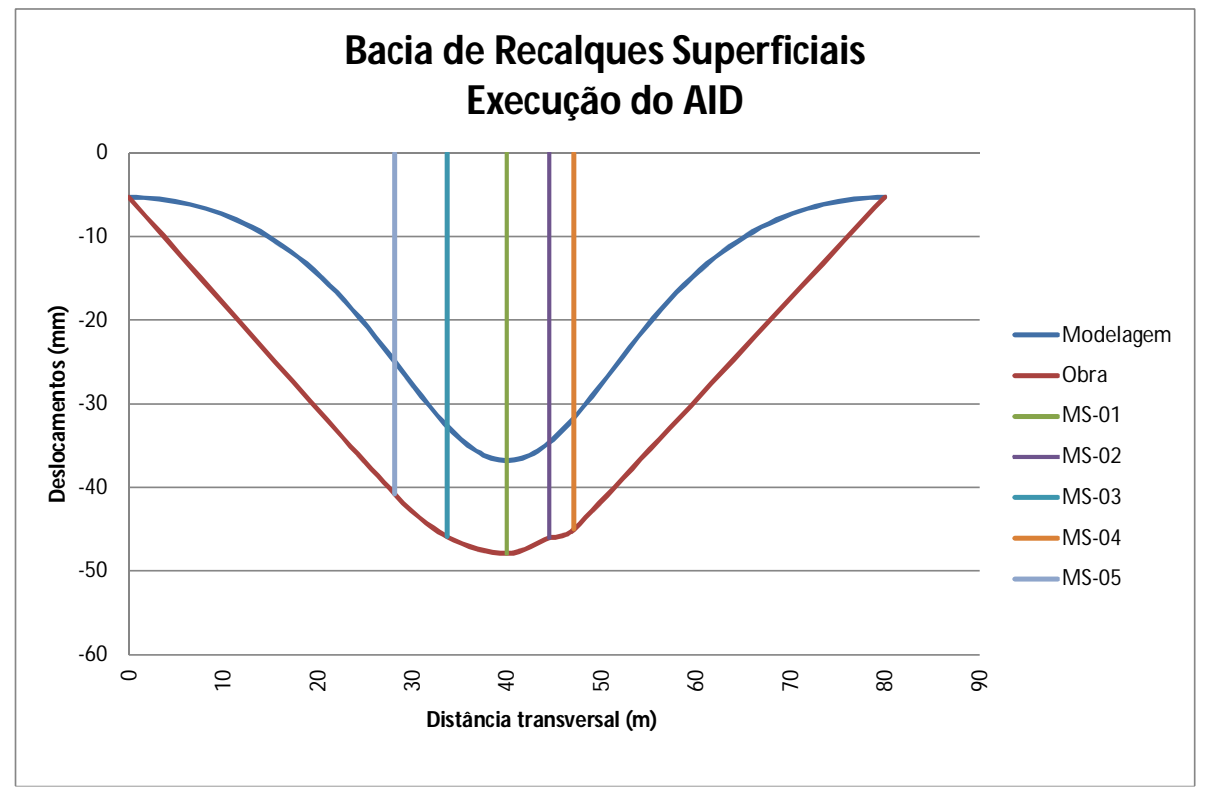

Figura 89 Bacia de recalques superficiais - AID: análise numérica x obra - Cenário 1

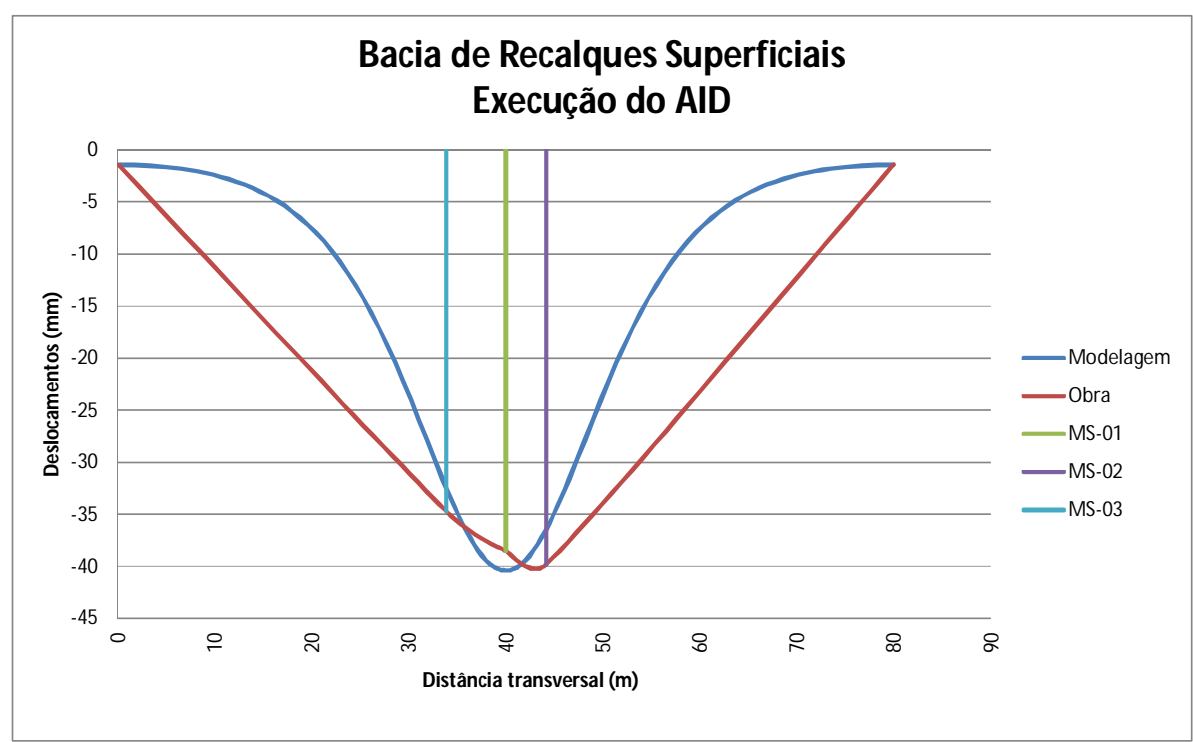

Figura 90 Bacia de recalques superficiais - AID: análise numérica x obra - Cenário 2 


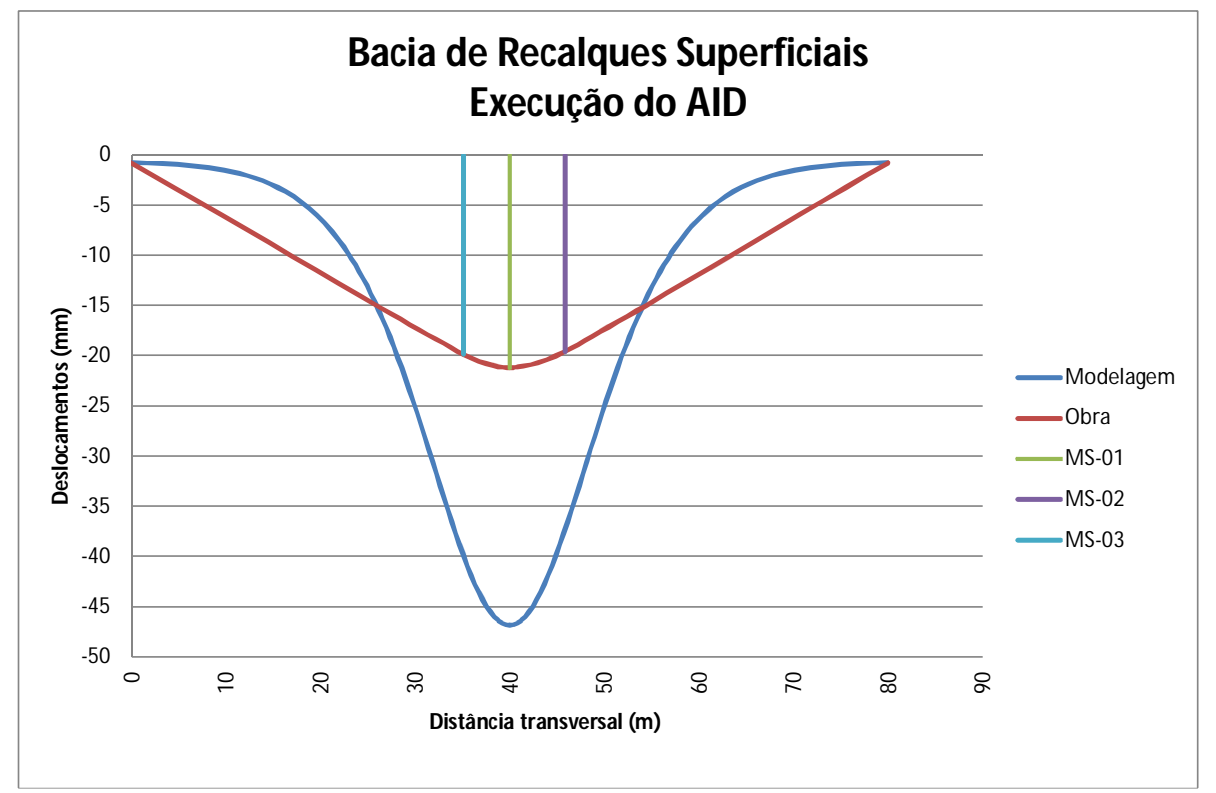

Figura $91 \quad$ Bacia de recalques superficiais - AID: análise numérica x obra - Cenário 3

Os gráficos abaixo ilustram os deslocamentos obtidos no interior do maciço, após a execução do AID, obtidas por meio da análise numérica e da instrumentação da obra (tassômetros).

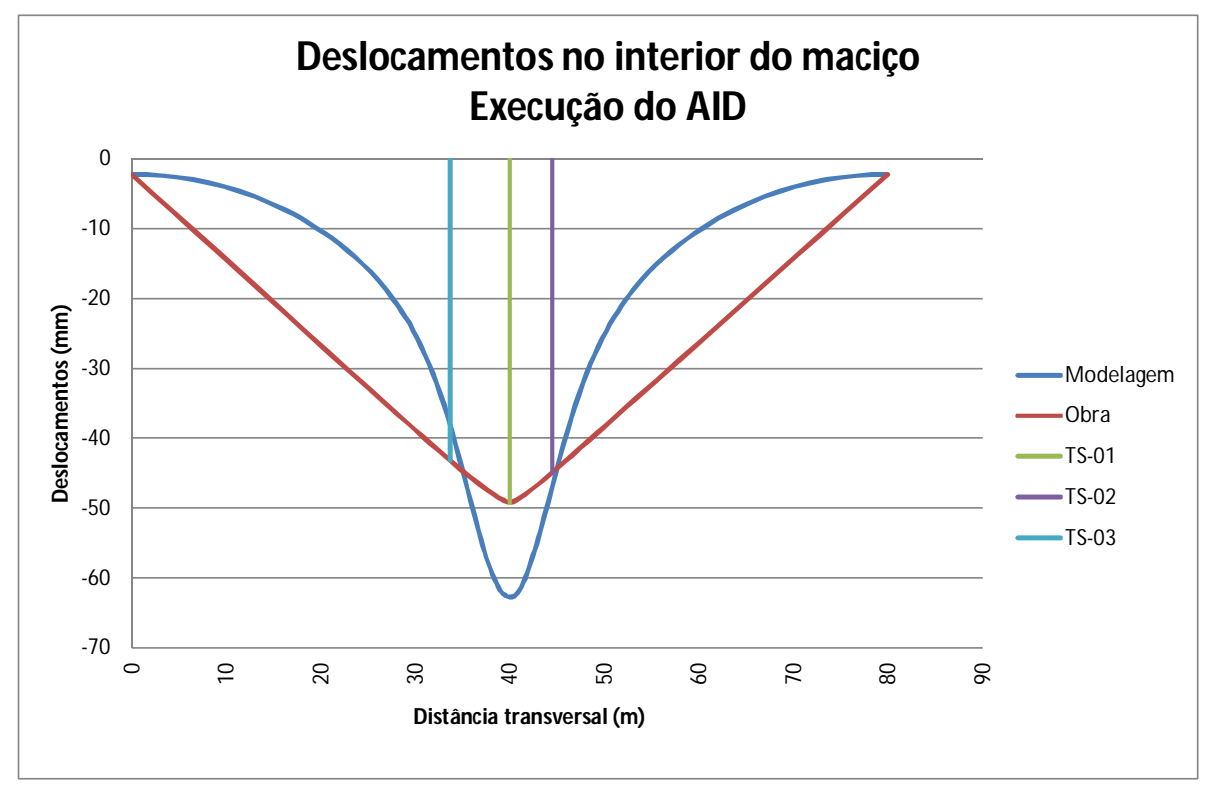

Figura 92 Deslocamentos no interior do maciço: análise numérica x obra - Cenário 1 


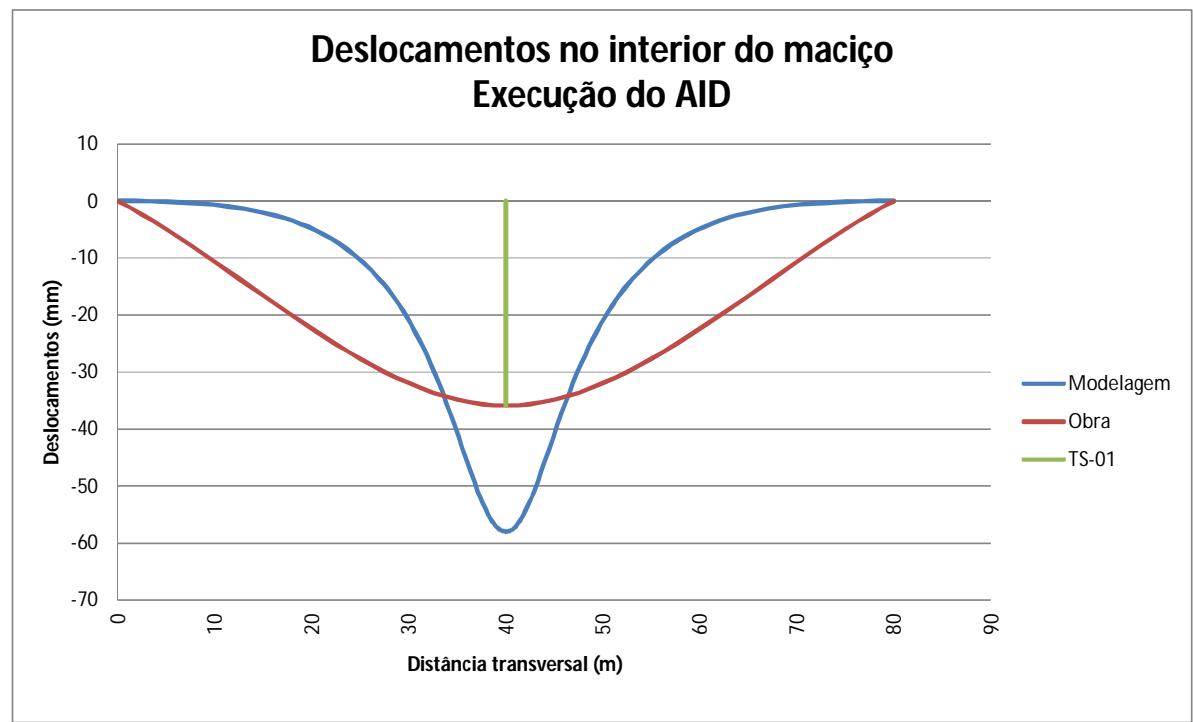

Figura 93 Deslocamentos no interior do maciço: análise numérica x obra - Cenário 2

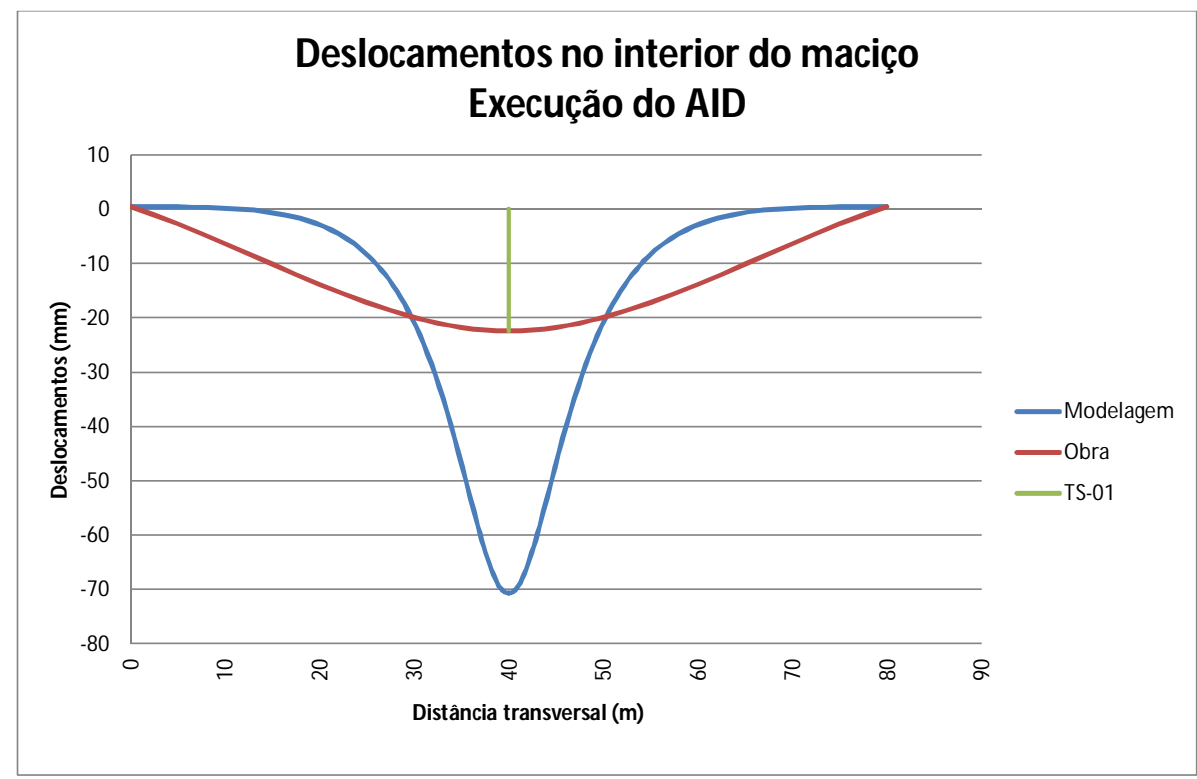

Figura 94 Deslocamentos no interior do maciço: análise numérica x obra - Cenário 3

Os gráficos abaixo ilustram os deslocamentos superficiais ao longo da execução do túnel, obtidos por meio da análise numérica e da instrumentação da obra. 


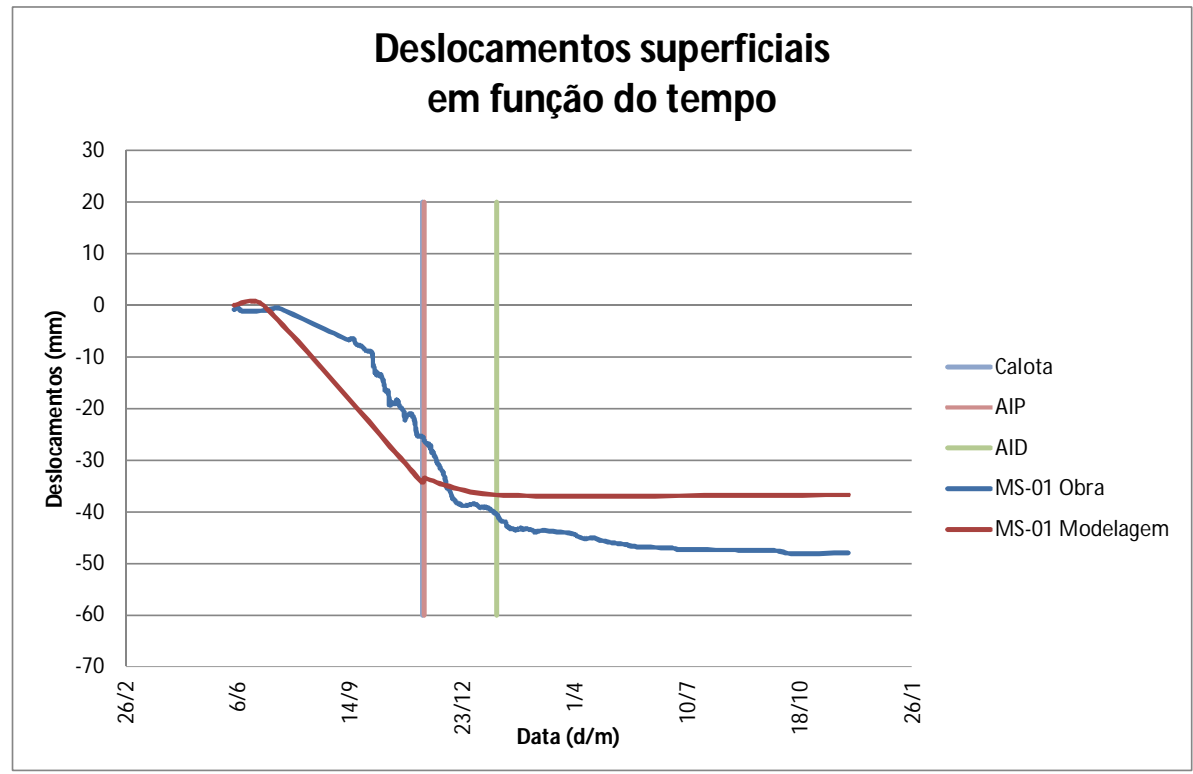

Figura 95 Deslocamentos superficiais em função do tempo: análise numérica x obra - Cenário 1

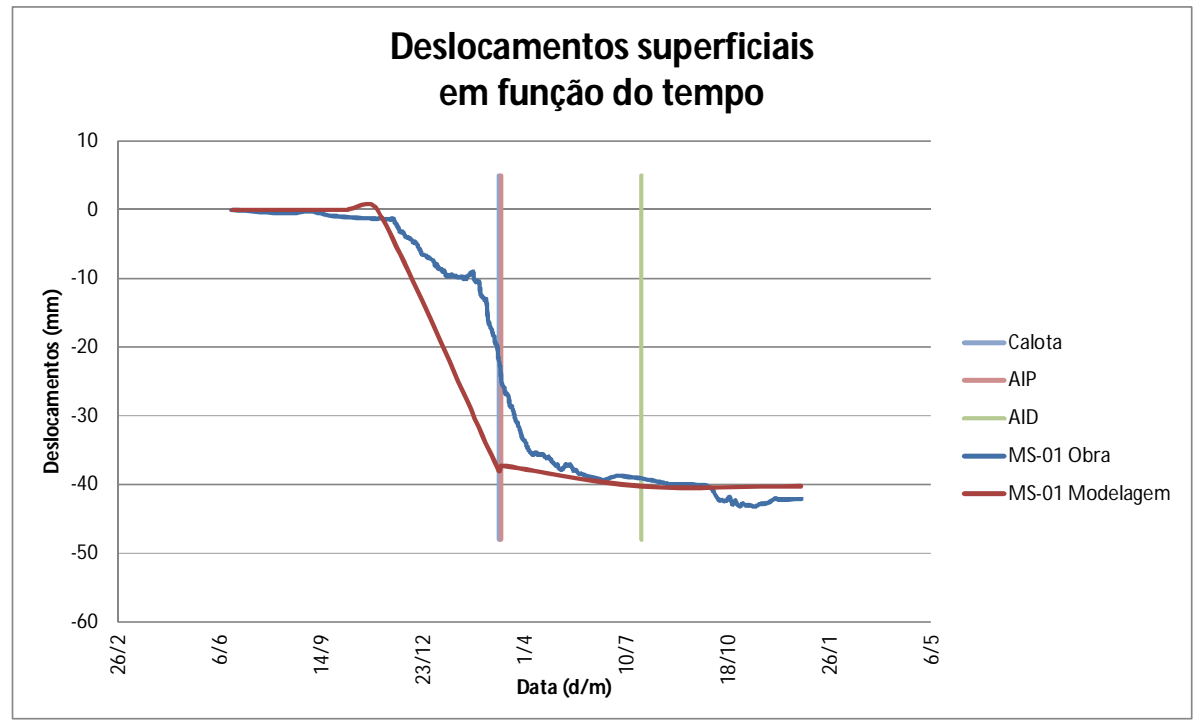

Figura 96 Deslocamentos superficiais em função do tempo: análise numérica x obra - Cenário 2 


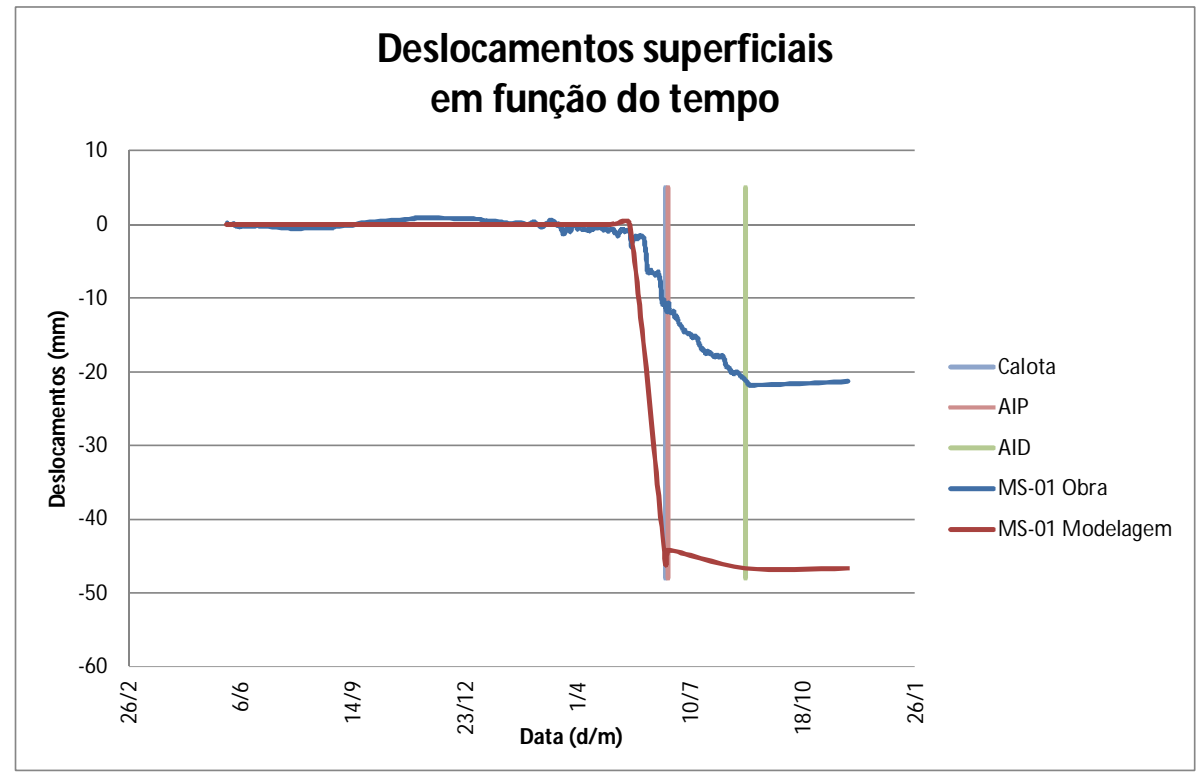

Figura 97 Deslocamentos superficiais em função do tempo: análise numérica x obra - Cenário 3

Os gráficos abaixo ilustram os deslocamentos no interior do maciço ao longo da execução do túnel, obtidos por meio da análise numérica e da instrumentação da obra (tassômetros).

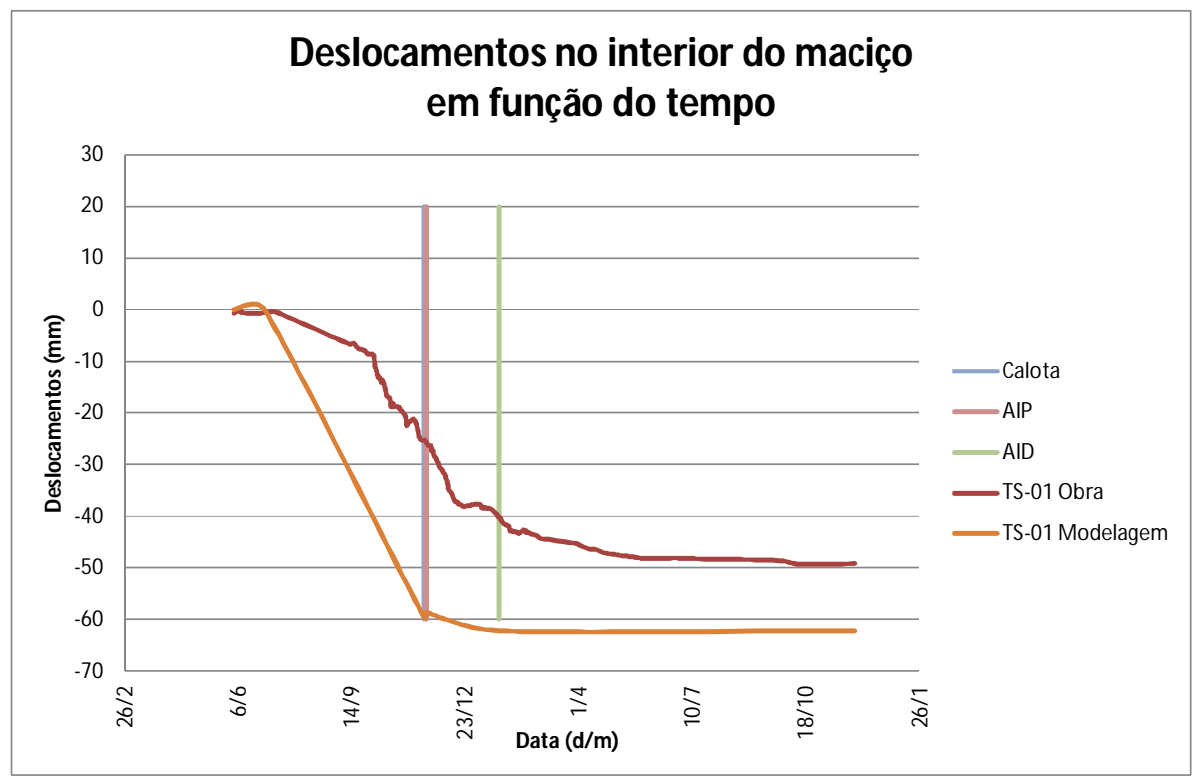

Figura 98 Deslocamentos no interior do maciço em função do tempo: análise numérica x obra Cenário 1 


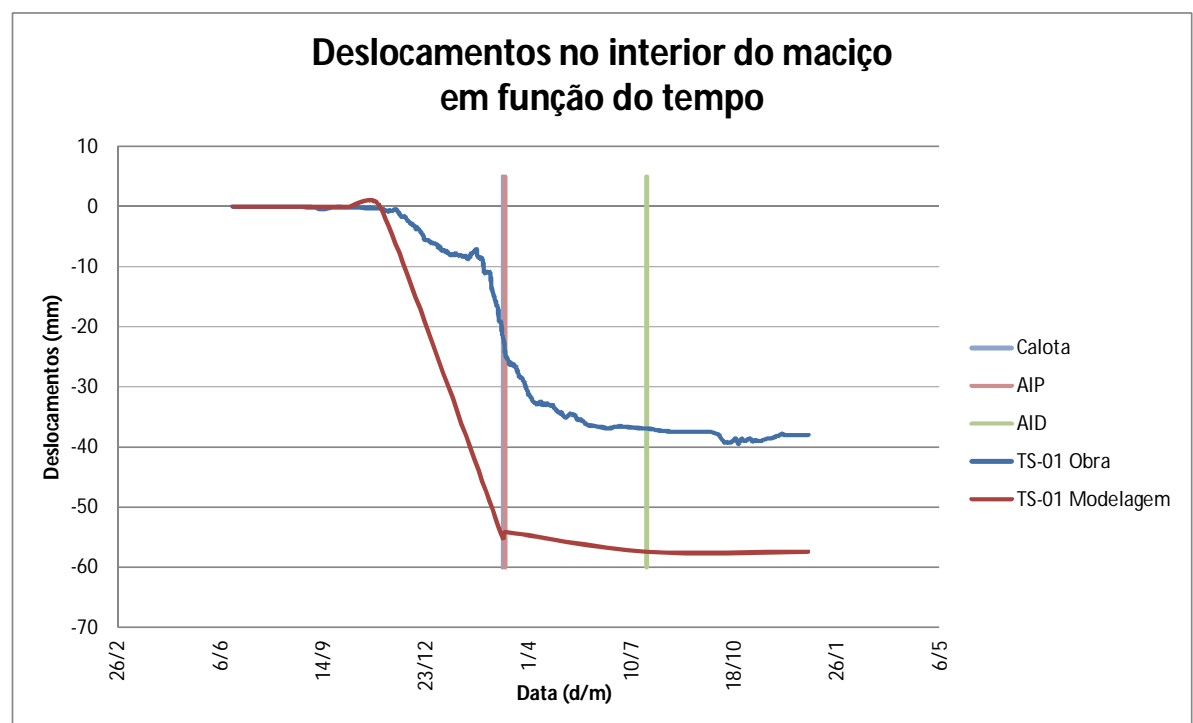

Figura 99 Deslocamentos no interior do maciço em função do tempo: análise numérica $x$ obra Cenário 2

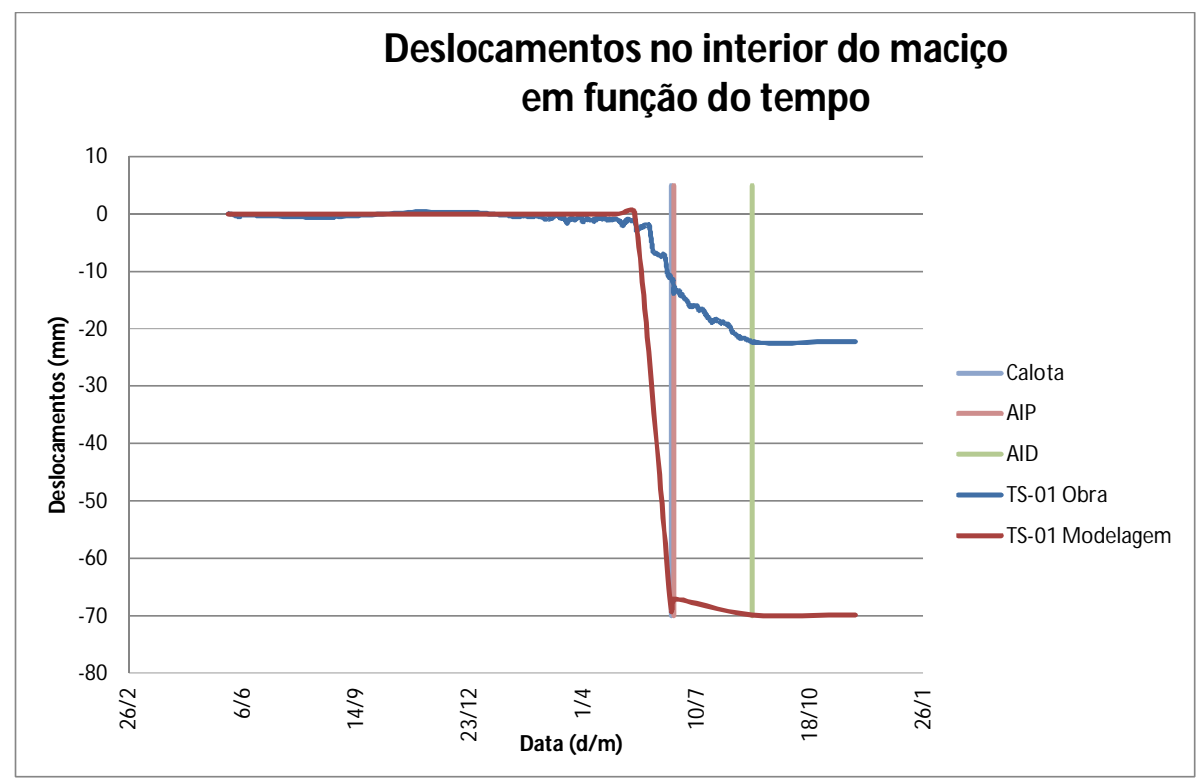

Figura 100 Deslocamentos no interior do maciço em função do tempo: análise numérica x obra Cenário 3

Conforme se pode observar nos gráficos apresentados, a correlação entre os dados de campo e os resultados das modelagens numéricas é muito heterogênea. Em algumas situações, a modelagem representa de forma muito satisfatória a realidade, como é o caso das bacias de recalques após a execução do AID, nos cenários 1 e 2 , bem como dos deslocamentos superficiais em função do tempo, nos mesmos cenários. Em outras situações, há uma divergência muito grande entre os resultados das modelagens numéricas e os dados de campo, como é o caso dos gráficos do 
cenário 3. Essa heterogeneidade pode ser notada nos resultados de um mesmo cenário, como no cenário 2; a modelagem numérica é extremamente eficiente ao representar os recalques superficiais após a execução do AID, e deficiente para representar os recalques superficiais após a execução da Calota.

Sabe-se que modelos numéricos mais elaborados, que representem melhor a realidade, são viáveis utilizando programas mais poderosos, em três dimensões, com execução de uma campanha de investigação geotécnica mais detalhada e ensaios refinados para determinação dos parâmetros dos materiais. No entanto, o conhecimento inevitavelmente limitado da configuração geológica e características do solo na fase de projeto, bem como as simplificações utilizadas nas ferramentas de simulação disponível e as nuanças dos métodos construtivos, resultam, em geral, em modelos imprecisos de estruturas subterrâneas. Como o comportamento do solo pode variar numa vasta gama, suas reais características dificilmente são conhecidas com exatidão antes da execução da obra. Portanto, é muito importante que o conceito de níveis de alerta/atenção seja utilizado com muita cautela. Esses valores são fornecidos pelo projeto e entendidos pela equipe de campo como valores determinísticos obtidos por cálculos, e, assim, supõe-se que, antes deles serem atingidos, não há problemas de instabilidade na obra. Esse conceito fornece uma falsa sensação de segurança, pois pode haver colapso antes de se atingir tais valores.

Outro conceito importante que deve ser analisado consiste no soerguimento da estrutura após a execução do AIP. Ao comparar os deslocamentos resultantes das modelagens numéricas, tanto superficiais como no interior do maciço, observa-se uma diminuição da magnitude dos deslocamentos após a execução no AIP. Esse comportamento pode ser notado facilmente nos gráficos em função do tempo. Isso ocorre, nas modelagens numéricas, em virtude do alívio de tensões ao qual o maciço sob o AIP é submetido e pelo fato dos modelos não levarem em conta a histerese dos materiais (Maffei 2013, (informação verbal)). A histerese é a tendência de um material ou sistema de conservar suas propriedades na ausência de um estímulo que as gerou. De acordo com os resultados de campo, este comportamento de soerguimento da estrutura não ocorre na obra, conforme se pode observar nos gráficos.

De forma geral, pode-se afirmar que os modelos de cálculo adotados para os 
cenários 1 e 2 representam de forma satisfatória a realidade dos deslocamentos em campo.

No entanto, os resultados da modelagem do cenário 3 apresentam uma grande discrepância em relação aos deslocamentos medidos em campo. Esse comportamento ocorreu, provavelmente, por causa dos tratamentos de frente e alterações na metodologia construtiva adotada para esse trecho. Conforme se pode observar no perfil geológico desta região, o maciço é constituído de solos arenosos. O rebaixamento do lençol freático, através de poços com bombas submersas (PBS), não foi eficiente nesse trecho, demandando a utilização de: drenos horizontais profundos (DHP's), pregagens de frente, ora com tubos de PVC injetados, ora com colunas de CCPH. Apesar de a piezometria indicar o nível do lençol freático abaixo da camada de solo arenoso, no decorrer da execução do túnel verificou-se a presença de água na frente de escavação. A metodologia construtiva foi alterada de forma a executar o AIP o mais próximo da frente de escavação possível. Com essas intervenções e a consequente reclassificação do maciço, os deslocamentos obtidos na obra foram muito inferiores aos calculados na modelagem numérica.

No Cenário 1 , o recalque superficial máximo no eixo do túnel, obtido com a análise numérica, foi de $36,7 \mathrm{~mm}$, valor inferior aos $47,9 \mathrm{~mm}$ medidos em campo. A bacia obtida em campo se mostrou mais suave do que a verificada na modelagem numérica, que apresentou uma forma mais fechada, com maiores distorções na região central. Pode-se dizer que a análise numérica forneceu um resultado da bacia de recalques superficiais de qualidade razoável a boa. Vale ressaltar, no entanto, que a análise resultou em valores de distorções superiores aos que realmente ocorreram em campo. Esse fato, dependendo do tipo de edificação situado nas proximidades do túnel, poderia indicar uma falsa situação de risco para a estrutura da edificação.

Os deslocamentos verticais no interior do maciço, próximos ao túnel, apresentam valor máximo com a análise numérica de 62,2mm, valor superior aos 49,2 mm medidos em campo, e ocorrem, como esperado, sobre o eixo do túnel. A distribuição transversal dos deslocamentos obtida em campo se mostrou mais suave do que a verificada na modelagem numérica. $\mathrm{O}$ valor obtido no tassômetro TS-01 é apenas 8,7\% superior ao valor do tassômetro TS- 02 .

Os dados de instrumentação indicam que os deslocamentos em regiões mais 
profundas foram superiores aos das regiões mais superficiais, compatíveis com os deslocamentos crescentes com a profundidade obtidos na análise numérica. Esse é o comportamento típico observado na maioria dos túneis em solo, em função do arqueamento das tensões no maciço.

No Cenário 2, o recalque superficial máximo no eixo do túnel obtido com a análise numérica foi de 40,24mm, valor superior aos $38,8 \mathrm{~mm}$ medidos em campo, no marco superficial MS-02, deslocado do eixo do túnel. A bacia obtida em campo se mostrou muito próxima da modelagem numérica, levando em conta a extrapolação linear feita nas extremidades dos dados da instrumentação. Pode-se dizer que a análise numérica forneceu um resultado da bacia de recalques superficiais de qualidade razoável a boa. Vale ressaltar, no entanto, que as análises dos deslocamentos verticais obtidos com a execução da Calota e do AIP, indica valores superiores aos registrados em campo, resultando em diferenças de até $37,4 \%$, referentes aos recalques máximos após a execução da Calota. A forma da bacia de recalques obtida em campo, nesses dois casos, se mostrou mais suave do que a verificada na modelagem numérica, que apresentou uma forma mais fechada, com maiores distorções na região central.

Da mesma forma, os deslocamentos verticais no interior do maciço, próximos ao túnel, apresentam valor máximo com a análise numérica de $57,4 \mathrm{~mm}$, valor superior aos $35,9 \mathrm{~mm}$ medidos em campo, ocorrendo sobre o eixo do túnel. A distribuição transversal dos deslocamentos obtida em campo se mostrou mais suave do que a verificada na modelagem numérica.

Os dados de instrumentação indicam que os deslocamentos em regiões mais profundas foram inferiores aos deslocamentos em regiões mais superficiais; contrapondo-se aos deslocamentos obtidos com a análise numérica que indicam deslocamentos crescentes com a profundidade. Esse comportamento é resultado da camada superficial de argila porosa $\left(3 \mathrm{Ag}_{\mathrm{P} 1}\right)$ desta região. Sabe-se que esse material é colapsível e extremamente sensível a recalques diferenciais, ocasionando significativa redução volumétrica.

No Cenário 3, o recalque superficial máximo no eixo do túnel obtido com a análise numérica foi de $46,6 \mathrm{~mm}$, valor muito superior aos $21,2 \mathrm{~mm}$ medidos em campo. Conforme mencionado, a análise numérica forneceu resultados muito discrepantes dos resultados de campo. Essa diferença se deve aos tratamentos de maciço e 
métodos construtivos adotados para este trecho.

Vale ressaltar, no entanto, que, em função da camada superficial de argila porosa $\left(3 \mathrm{Ag}_{\mathrm{P} 1}\right)$ dessa região, os dados de instrumentação indicam que os deslocamentos em regiões mais profundas foram inferiores aos deslocamentos em regiões mais superficiais, contrapondo aos deslocamentos obtidos com a análise numérica que indicam deslocamentos crescentes com a profundidade. Esse comportamento é semelhante ao observado no Cenário 2. Nota-se que o maciço superficial do Cenário 1 também é composto da camada superficial de argila porosa (3Ag $\left.\mathrm{P} 1_{\mathrm{P}}\right)$. No entanto, em função da profundidade do túnel e da escavação em solo residual, a influência da camada colapsível é minimizada. 


\section{CONSIDERAÇÕES FINAIS}

$\mathrm{Na}$ engenharia geotécnica, em obras de túneis, grandes esforços são despendidos para se obter aproximações de valores das propriedades físicas do solo e do maciço, que aparecem em equações de cálculo e parâmetros de modelos matemáticos. Muitas variáveis permanecem desconhecidas na precisão desejável, como o grau de continuidade de substratos importantes ou as condições do lençol freático ao longo da obra. Portanto, os resultados de cálculos e análises computacionais não são mais do que valores referenciais baseados em hipóteses de trabalho, sujeitas às confirmações ou modificações durante a construção.

Assim, na fase de projeto, faz-se a coleta de toda e qualquer informação que se possa conseguir para construir um cenário com hipóteses que cubram condições potencialmente desfavoráveis de esforços na estrutura. Para não haver superdimensionamento das estruturas, os cenários são definidos de forma que o projetista considere a mais realista possível. Por essa razão, é necessário coletar posteriormente, em campo, dados de carregamentos e deslocamentos da estrutura, que servirão para indicar eventuais imprevistos no projeto. Se necessário, revisa-se o projeto durante a construção.

Portanto, o projeto de instrumentação terá como principais objetivos:

- Monitorar o comportamento do maciço e das estruturas face aos efeitos da execução da obra, procurando detectar antecipadamente eventuais mecanismos de colapso, os quais indicarão a necessidade da aplicação de contramedidas de segurança.

- Permitir a avaliação do comportamento maciço-estrutura real. Os resultados da instrumentação subsidiarão eventuais necessidades de revisões e aprimoramentos do projeto e do método construtivo.

Para a definição do projeto de instrumentação, é necessário, em primeiro lugar, prever os mecanismos de colapso possíveis. Com a identificação dos mecanismos de colapso, podem-se prever as formas de movimentação do maciço e da estrutura, e, por consequência, definir os locais e tipos de instrumento para leitura.

Portanto, as indicações do projeto devem ser utilizadas como diretrizes e referências para a execução da obra. As avaliações de estabilidade e segurança da obra devem ser realizadas permanentemente, por equipe especializada, ao longo da execução 
do empreendimento, por meio de diagnóstico dos dados da instrumentação diária e das inspeções visuais, ainda que os instrumentos não apresentem valores inesperados.

Assim, durante a execução da obra, deverá haver uma equipe de acompanhamento técnico de obras que realize uma avaliação global de todas as informações, considerando ao menos:

- Resultados da instrumentação;

- Diário de obras com indicação de todos os eventos que possam influenciar as medições dos instrumentos;

- Eventuais sinais nas estruturas e maciços;

- Premissas consideradas pelos desenhos e memoriais de cálculo do projeto;

- A avaliação deverá contemplar uma análise de todos os aspectos que possam ser considerados anormais e fazer um diagnóstico indicando ações a serem tomadas ou justificativas que esclareçam os resultados de forma a elucidar as anormalidades.

- A empresa de instrumentação deverá disponibilizar os resultados das leituras diariamente, no mesmo período (dentro do ciclo de trabalho de cada turno) da realização da leitura. Os resultados deverão ser apresentados à equipe de ATO no formato de tabelas e gráficos em função do tempo e dos avanços.

A geometria do túnel tem fundamental importância nos esforços internos do revestimento, de tal modo que, nos casos em que a forma da seção do túnel seja desfavorável, pode haver flexão no revestimento, o que, consequentemente, pode levá-lo ao colapso. Nos túneis em solo, é mais importante a estabilidade do maciço com o equilíbrio do revestimento, de modo que a instrumentação sirva mais para detectar eventuais instabilidades (mecanismos de ruptura) do que para aperfeiçoar o revestimento.

Mecanismos provocados por cisalhamento podem ser consequências de deficiências no projeto ou na execução da obra. No projeto, a falha pode ocorrer no 
dimensionamento dos esforços, no detalhamento inadequado da ligação e na geometria desfavorável concebida. Um dos pontos críticos para a ocorrência da ruptura por cisalhamento é na lateral da seção, onde ocorrem as juntas de concretagem entre a calota e o arco invertido. Essa região encontra-se próximo ao piso na fase de escavação da calota, na qual ocorre acúmulo de sujeira e material de reflexão. O mau desempenho das ligações pode resultar em colapsos da estrutura, muitas vezes sem aviso.

Em relação à interpretação da instrumentação, os níveis de alerta devem ser utilizados, caso necessário, com muito cuidado. O valor de referência ou de alerta fornecido pelo projeto é entendido pela equipe da obra como valor determinístico obtido por cálculos e, assim, supõe-se que antes dele ser atingido não há problemas de instabilidade na obra. Esse valor fornece uma falsa sensação de segurança, pois pode haver colapso antes de se atingir tais valores. De acordo com o exposto no item 6, os valores de deslocamentos são muito influenciados pelo método construtivo, tipo de tratamento, profundidade do túnel, sistema de rebaixamento do lençol freático, presença de solos colapsíveis ou expansivos etc. Grande parte desses elementos é de difícil modelagem numérica. Portanto, caso seja obrigatório o fornecimento de níveis de alerta, o melhor é que ele seja determinado de forma racional para cada tipo de mecanismo de ruptura que possa ocorrer.

Considerando o maciço como meio contínuo, os modelos de interação para a determinação de esforços e deslocamentos podem ser de dois tipos - Modelo de Ações Espontâneas (MAE) ou Modelo de Ações Impostas (MAI). A aplicação do MAI é adequada para o dimensionamento no estado-limite último, porque o carregamento a resistir é o potencial imposto, enquanto o MAE é adequado para a verificação do estado-limite de utilização, para avaliação dos deslocamentos em serviço. Naturalmente, a utilização do MAE também poderá servir para o dimensionamento, desde que os resultados sejam adequadamente interpretados.

Em obras de túneis, deve-se definir uma equipe de gerenciamento de riscos para acionamento e realização das medidas de segurança e contingência na ocorrência da eventualidade no decorrer da obra. Essa equipe deve elaborar um protocolo de 
procedimentos para interrupção da obra, isolamento de áreas, evacuação da superfície e acionamento das medidas de contingência necessárias, como: sacos de areia, material para reaterro, fornecimento de concreto projetado de emergência, madeira ou metal para escoramento e material para isolamento e sinalização, como: cavaletes, cones, cordões, e placas de sinalização para eventualidades, conforme orientação da engenharia de segurança para eventuais áreas com risco de colapso. 


\section{REFERÊNCIAS BIBLIOGRÁFICAS}

(01) RABCEWICZ, L.V, Novo Método Austríaco de Abertura de Túneis, São Paulo ABGE, 1974.

(02) MAFFEI, C.E.M, Diretrizes para o Projeto de Túneis, Metrô SP, São Paulo, 1995.

(03) UBIERNA, J.A.J, El. Túnel I. Historia Y Mito. Colegio de Ingenieros de Caminos Canales Y Puertos, 1990. 360p.

(04) SZÉCHY, K, The Art of Tunnelling, Akadémiai Kiadó, Budapest, 1973.

(05) MAFFEI, C.E.M, Projeto de Túneis: Notas Sobre o Passado, Presente e Futuro, $3^{\circ} \mathrm{CBT}$, São Paulo, 2012.

(06) SILVA TELLES, P.C. Túneis Antigos do Brasil. In: T.B. Celestino, A. Koshima, R.C.A. Telles \& A.P. Assis (Eds.) Túneis do Brasil. Comitê Brasileiro de Túneis- ABMS, São Paulo. 2006.

(07) NEGRO, A., SOZIO, L. E., FERREIRA, A. A., Solos da Cidade de São Paulo, ABMS e ABEF, São Paulo, 1992.

(08) SGA Noticias. Assalto ao Banco Central de Fortaleza, Disponível em: http://www.sganoticias.com.br/2011/07/assalto-ao-banco-central-defortaleza.html. Acesso em: 25 Nov. 2012.

(09) DIÁLOGOS POLÍTICOS. Assalto ao Banco Central de Fortaleza, Disponível em: <http://www.dialogospoliticos.wordpress. com/2010/06/01/assalto-aobanco-central-de-fortaleza-vai-virar-filme/. Acesso em: 25 Nov. 2012.

(10) MURAKAMI, C. A, Noções Básicas para o Acompanhamento Técnico de Obras de Túneis, São Paulo. POLI-USP, 2001.

(11) DEPARTAMENTO DE ESTRADAS DE RODAGEM - DER, Instruções de projeto de túnel, 2005.

(12) PBA - Plano Básico Ambiental - RT 5.00.00.00/8N4 - 004 - Rev. C Expansão da Linha 5 (lilás) do Metrô de São Paulo, 2010.

(13) ROCHA , H. C. Panorama do Mercado Brasileiro de Túneis: Passado, Presente e Futuro - $54^{\circ}$ Congresso Brasileiro do Concreto, São Paulo, 2012.

(14) Prefeitura de São Paulo.Atlas Ambiental do Município de São Paulo, Disponível em: http://atlasambiental.prefeitura.sp.gov.br/pagina.php?id=28. Acesso em: 25 Nov. 2012. 
(15) VAZ, L. F. Origem E Tipos De Solos - IG/UNICAMP 2003.

(16) RICCOMINI, C. O Rift continental do Sudeste do Brasil. Tese de Doutoramento apresentada ao Instituto de Geociências da Universidade de São Paulo, 1989, 256p.

(17) RELATÓRIO - RT-5.18.00.00/6C3-002 - Relatório Geológico-Geotécnico - Trecho 18-Largo 13/Adolfo Pinheiro. Consórcio LARGO 13, 2011.

(18) RELATÓRIO - RT-4.08.00.00/4C3- 002 - Relatório Geológico-Geotécnico - Promon Engenharia Ltda., 1994.

(19) GAMBOA V.P., Placas e Cascas, Universidade da Beira Interior, Covilhã, Portugal, 2009.

(20) ROCHA, M. Mecânica das Rochas, LNEC, Lisboa, Vol. 1, 1971, 276p.

(21) FRANCA, P. T. Estudo do comportamento de túneis: analise numérica tridimensional com modelos elasto-plásticos. Dissertação de Mestrado. Escola Politécnica, Universidade de São Paulo, São Paulo, 2006, 206 p.

(22) EISENSTEIN, Z. D.; HEINZ, H.; NEGRO Jr., A. On three-dimensional response to tunneling. Proc. Geotech '84, American Society of Civil Engineers, 1984, p. 107-127.

(23) KOLYMBAS, Dimitrios., Tunnelling and Tunnel Mechanics, 2005.

(24) Rockscience, Inc. - Phase2 Users Manual, version 5.0. Toronto, 2001, 173 p.

(25) Penido, H.A. - Modelagem Computacional de Túneis: 0 Caso dos Túneis da Mina de Fábrica Nova. Dissertação de Mestrado -Escola de Minas UFOP. 2006, 173p.

(26) Leite, E.N. - Estudo do Comportamento Geomecânico do Pilar Superior da Mina Ipueira V (Ferbasa Mineração - Andorinha, BA). Dissertação de Mestrado -Escola de Minas - UFOP. 2004, 81p.

(27) Brady, B. H. G. \& Brown, E. T. - Rock mechanics for underground mining. Allen and Unwin. London. 1985, 527 p.

(28) MACHADO, G. M. - Análise por Elementos Finitos de Maciços Escavados por Túneis, Dissertação de Mestrado. Escola Politécnica, Universidade de São Paulo, São Paulo, 2011, 102 p.

(29) Pinto C. S. Curso básico de Mecânica dos Solos. 3ª Edição. São Paulo: Oficina de Textos, 2006, 367p. 
(30) IBAÑEZ, Juan Pablo; ROMANEL, Celso. Pontifícia Universidade Católica do Rio de Janeiro -, Departamento de Engenharia Civil. Modelagem constitutiva para solos com ênfase em solos não saturados. 2003. 241 f. Dissertação (Mestrado) , Disponível em: www2.dbd.pucrio.br/pergamum/tesesabertas /0124947_03_cap_03.pdf. Acesso em: 06 Ago. 2013.

(31) WOOD, D. M. Soil Behaviour and Critical State Soil Mechanics. $2^{\mathrm{a}}$ edição., New York: Cambridge University Press, 1990. 462 p.

(32) Companhia do Metropolinano de São Paulo, Saci5.0, Disponível em: https://aplic.metrosp.com.br/ebb/ Acesso em: 25 Nov. 2013.

(34) FUSCO, P. B. Técnica de armar as estruturas de concreto. Editora PINI. São Paulo, 2005.

(35) Vargas, M. - Introdução à Mecânica dos Solos - São Paulo, Ed. da Universidade de São Paulo, 1977, 509p.

(36) Constran. Contratos Metrô Linha 5 Lilás - Estação Adolfo Pinheiro Lote 1, Disponível em: http://www.constran.com.br/contratodetalhes. php?idcontrato=67\#prettyPhoto Acesso em: 25 Nov. 2013. 
ANEXO 1 - AUTORIZAÇÃO PARA UTILIZAÇÃO DOS DADOS

\author{
COMPANHIA dO METROPOLITANO dE SĀo PAULO \\ Aua Augusta, 1.626 - CEP 01304-902 - Cerqueira Cesar - Fax (11) 3283-5228 - Tel. (11) $3371-7411$

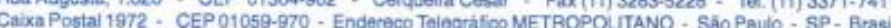

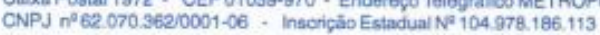 \\ CT GE5 850/2013 \\ 10 de setembro de 2013
}

PROF. DR. PAULO DE MATTOS PIMENTA

Orientador do curso de mestrado em engenharia geotécnica na POLI-USP

Avenida Miguel Frias e Vasconcelos, 756, ap. 83 tr. 01 - Jaguaré

São Paulo - SP

\title{
Prezado Senhor
}

Informamos que, conforme solicitação, está autorizada a utilizaçăo dos dados de projeto, instrumentação e ATO do lote 1 da Linha 5 - Lilás pelo aluno do curso de mestrado em engenharia geotécnica na POLIUSP, William Carreira, sob sua orientaçåo, desde que citada a fonte e para fins exclusivamente acadêmicos.

Atenciosamente,

$\overbrace{\text { LUIS BASTOS LEMOS }}^{2}$

Gerente do Empreendimento Linha 5 - Lilás

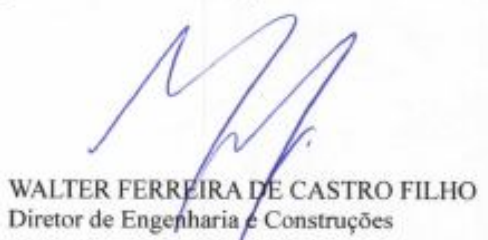




\title{
ANEXO 2 - DECLARAÇÃO DE CAPACIDADE TÉCNICA
}

\author{
4. construcat $\triangleq$ constran
}

DECLARAÇĀO

\author{
Atestamos, para os devidos fins, que a \\ Empresa GP CONSULTORIA EM PROJETOS DE ENGENHARIA CIVIL \\ $\begin{array}{ll} & \text { LTDA } \\ \text { Endereço: } & \text { Rua Moura Brasil, 183 - São Paulo - SP } \\ \text { CNPJ/MF } & n^{\circ} 07.086 .008 / 0001-61,\end{array}$ \\ RespiTéenicosl Garlos Eduardo Morciro Maffci CILA/ST n 17.400/D \\ Maria Cecilia Guazzelli - CREA/SP ne0682570320 \\ Paulo Eduardo Maffei - CREA/SP n\$5062148766 \\ Willian Carreira - CREA/SP no 5062141398 \\ Contrato $\quad n^{\circ}$ 5168-01/11 Obra C-1220/266 \\ Valor R\$450.000,00 (Quatrocentos e Cinquenta Mil Reais). \\ Período 28/03/2011 a 31/08/2012 \\ Local da Obra Rua Dr. Antônio Bento, nº6 - Santo Amaro - São Paulo
}

Executou consultoria para acompanhamento e assistência técnica às obras para escavaçăo e execução do suporte provisório dos túneis e poços, com respectiva análise dos resultados da instrumentaçăo, da obra bruta do Lote 1 da Linha 5 Lillas đa Compannía đó Metropolitano de Sảo Paulo, incluındo os trechos em túnel NATM, o Poço de Ventilaçăo e Saída de Emergência Delmiro Sampaio, estaçăo Adolfo Pinheiro e túnel de ligaçâa. $\mathrm{Os}$ trabalhos foram executados por engenheiro consultor em disposiçăo parcial com a realização de análise técnica dos serviços espécializádós (metodos de escavaçăo, geológıcos geotécnicos, tratamentos de maciço) e proposiçăo de alternativas mais seguras ou mais econômicas.

\section{OBJETO:}

Os serviços acima foram realizados na construçăo de um túnel com extensão total de $477,6 \mathrm{~m}$, projetados para abrigar o gabarito metroviário de $11,70 \mathrm{~m}$ de largura e $8,03 \mathrm{~m}$ de altura com duas vias e também passarclas de cmergĉncia nas duas laterais.

Os túneis atravessaram maciços que variaram desde seçōes plenas em solo residual até seçőes plenas em solo do terciário de São Paulo, em meio urbano sob a Av. Adolfo Pinheiro, área densamente ocupada por imóveis residenciais e estabelecimentos comerciais.

A obra foi executada através de seus 4 emboques. Dois dos emboques foram executados através dos poços da estação Adolfo Pinheiro, os outros dois emboques foram executados através de um túnel de ligação entre o poço de ventilação de saída de emergência Delmiro Sampaio e o túnel de via.

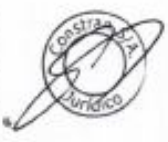

Para que as escavações de avanço fossem executadas com segurança, foram utilizados vários tipos de tratamentos de maciço, como: rebaixamento do lençol freático através de 206 PBS's (poços com bombas submersas), colunas de Jet-

Rua Doutor Antônio Bento, 106 - Santo Amaro - São Paulo - SP - CEP: 04750-000. Fone: (11) 5545-2620-Fax: (11) 5545-2622

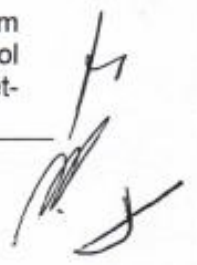




\section{- CONSTRUCAP A CONSTRAN}

grouting e enfilagens injetadas com tubos Schedule formando um arco protetor contra instabilidades do maciço.

Para manter a estabilidade da frente de escavação nos trechos críticos foram aplicadas pregagens de frente com colunas de Jet-grouting e barras de PVC.

\section{PARTICULARIDADES DA OBRA:}

- Estação Adolfo Pinheiro: constituida basicamente por cinco poços principais circulares interseccionados de $33,58 \mathrm{~m}$ de diâmetro e aproximadamente $17,5 \mathrm{~m}$ de profundidade, escavados em solo. Tais poços foram projetados utilizando-se o sistema NATM, com revestimento em concreto projetado e telas soldadas de aço e tratamento com paredes diafragma coulis.

Esta estação localiza-se sob a Av. Adolfo Pinheiro, em área densamente ocupada por estabelecimentos comerciais e de prestaçāo de serviços, e próximo a Santa Casa de Misericórdia de Santo Amaro, sendo que todos os trabalhos de escavação e contençōes ocorreram com todos estes estabelecimentos em plena operação.

- Túnel de via: túnel em solo em meio urbano para a implantaçăo das vias férreas do Metrô de São Paulo, Linha 5 (lilás), Lote 1, em extensão da ordem de $477,6 \mathrm{~m}$. Projetados para serem executados pelo sistema nāo destrutiva NATM (revestimento em concreto projetado com cambotas treliçadas metálicas e telas soldadas de aço), os túneis apresentam seções transversais com área de $81,04 \mathrm{~m}^{2}$ e cobertura de aproximadamente $15 \mathrm{~m}$. Cabe ressaltar que a regiāo de implantação da obra é densamente povoada, existindo na área de influência das escavaçōes diversas edificaçōes. Todas as edificaçōes destas áreas durante as obras são acompanhadas e, sempre que necessário, instrumentadas, de maneira a garantir a segurança de sua utilizaçăo e seu funcionamento;

- Poço de ventilação e saída de emergência Delmiro Sampaio constituída basicamente por um poço circular de $12,0 \mathrm{~m}$ de diâmetro e aproximadamente $27 \mathrm{~m}$ de profundidade, escavados em solo. Tal poço foi projetado utilizando-se o sistema năo destrutivo NATM, com revestimento em concreto projetado e telas soldadas de aço.

- Túnel de ligaçăo túnel em solo em meio urbano para interligar o poço de ventilação e saída de emergência Delmiro Sampaio e o túnel de via. Tal túnel foi executado pelo sistema não destrutivo NATM (revestimento em concreto projetado com cambotas treliçadas metálicas e telas soldadas de aço), apresenta extensão aproximada de $28,0 \mathrm{~m}$ e seçăo transversal com área de $154,45 \mathrm{~m}^{2}$, com largura e altura da ordem de $11,7 \mathrm{~m}$ e $15,89 \mathrm{~m}$, respectivamente, e cobertura de $14 \mathrm{~m}$, năo tendo ocorrido para sua

Rua Doutor Antônio Bento, 106 - Santo Amaro - São Paulo - SP - CEP: 04750-000.

Fone: (11) 5545-2620 - Fax: (11) 5545-2622
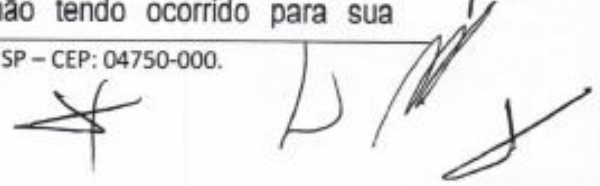


\section{\& CONSTRUCAP A CONSTRAN}

execução qualquer interrupçăo do tráfego existente. As contenções frontais para os emboques do túnel foram realizados com agulhamento de barras de aço CA-50 e enfilagem tubulares injetadas no contorno.

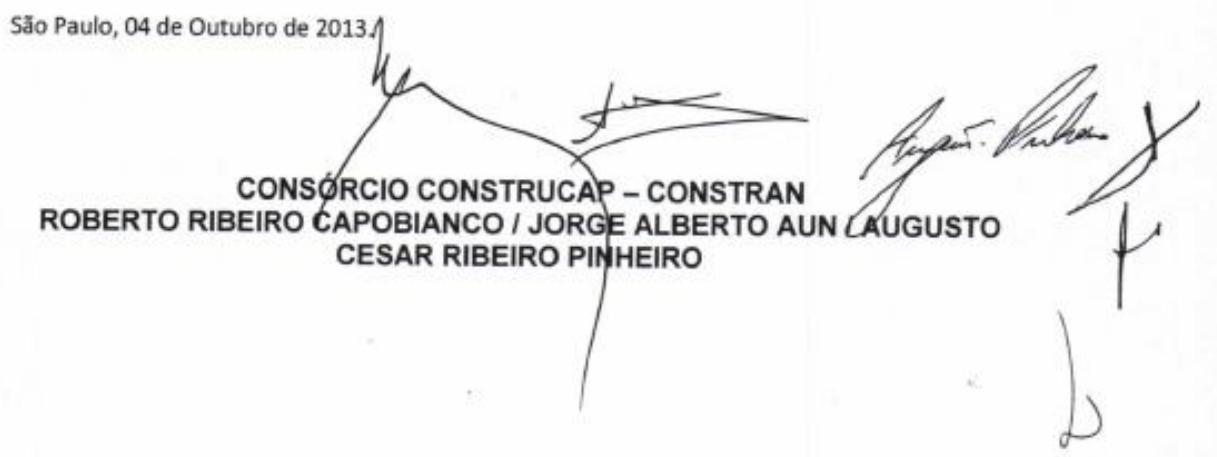

Rua Doutor Antônio Bento, 106 - Santo Amaro - São Paulo - SP - CEP: 04750-000. Fone: (11) 5545-2620 - Fax: (11) 5545-2622 


\section{ANEXO 3 - FOTOS}

\section{Fotos da Estação Adolfo Pinheiro}

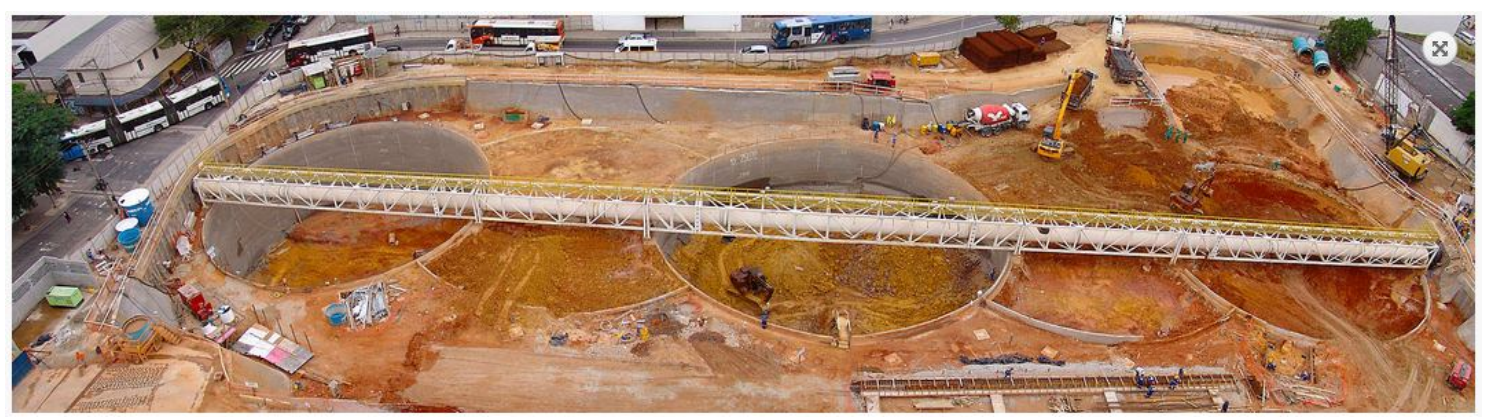

(Foto copiada do site da Constran (36))

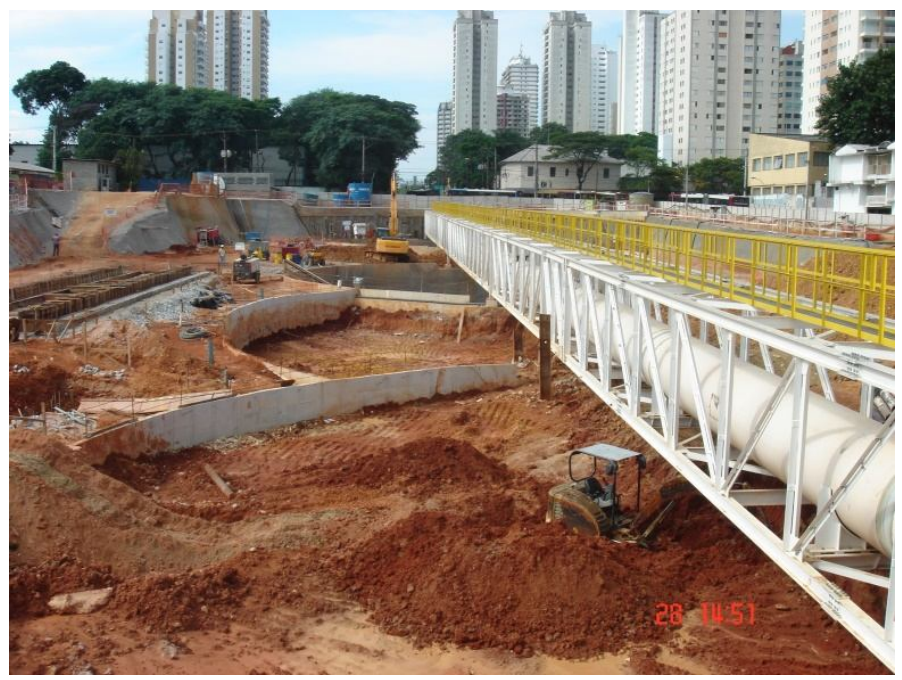



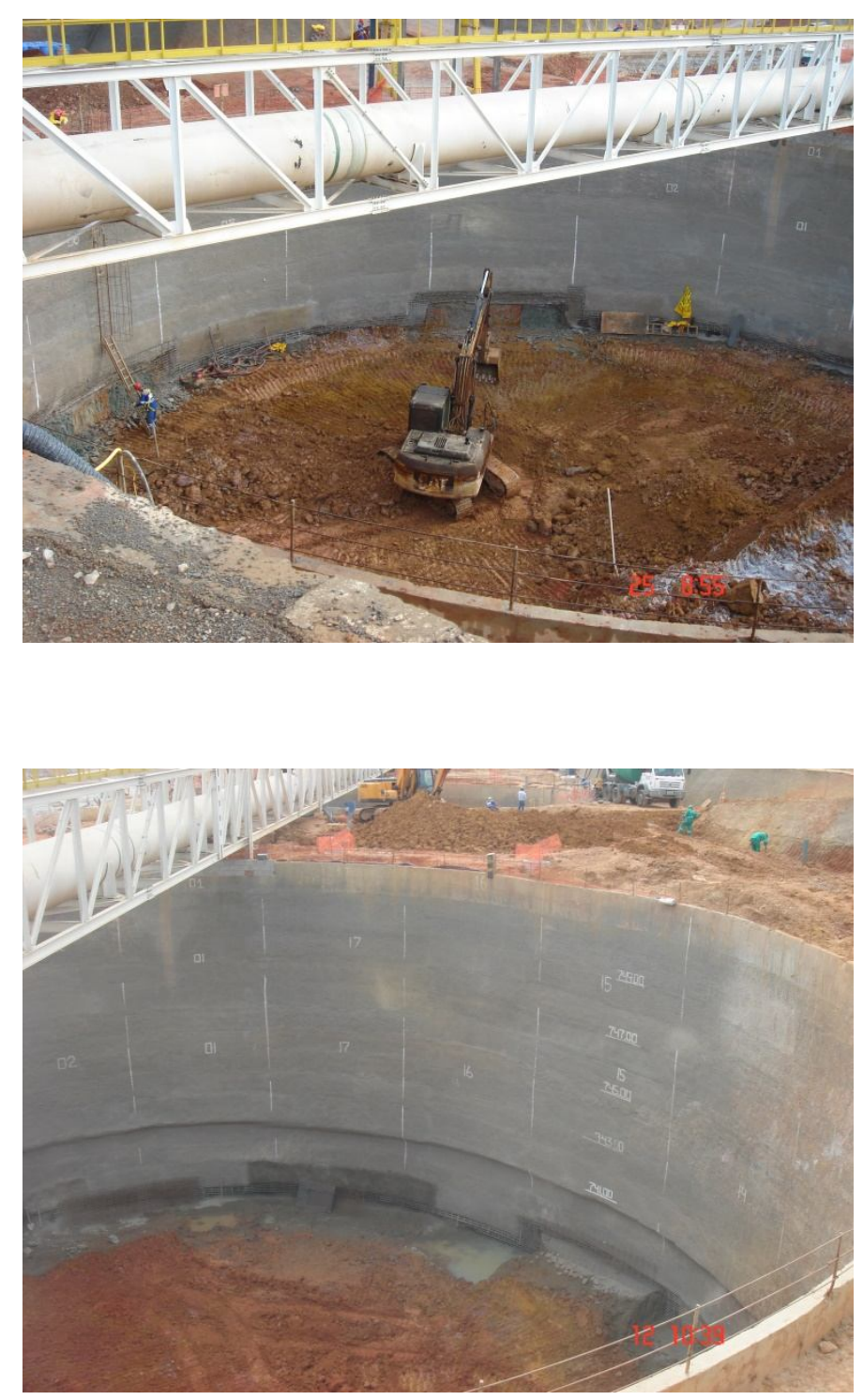
Fotos do Poço de Ventilação e Saída e Emergência
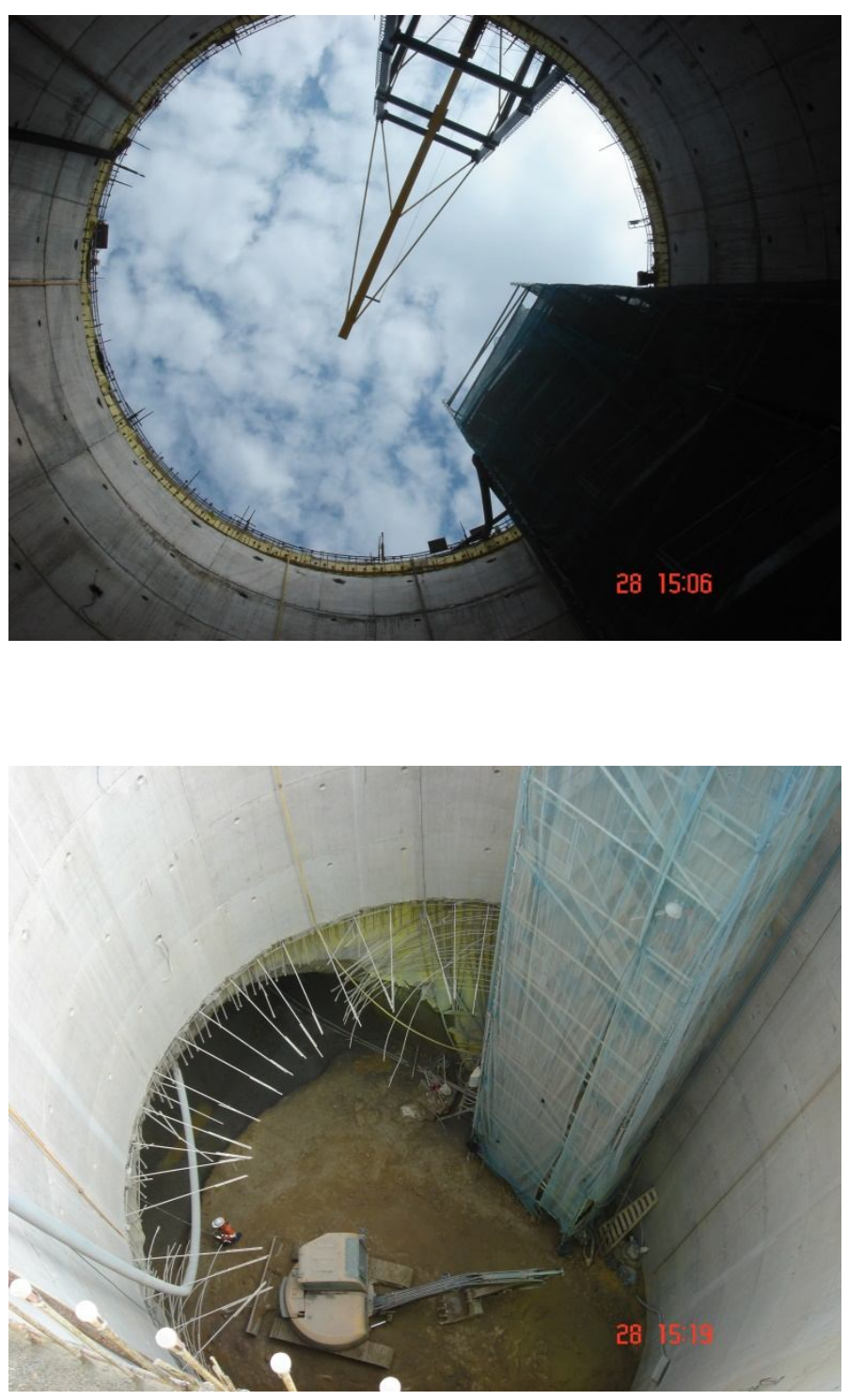
Fotos do Túnel de Ligação
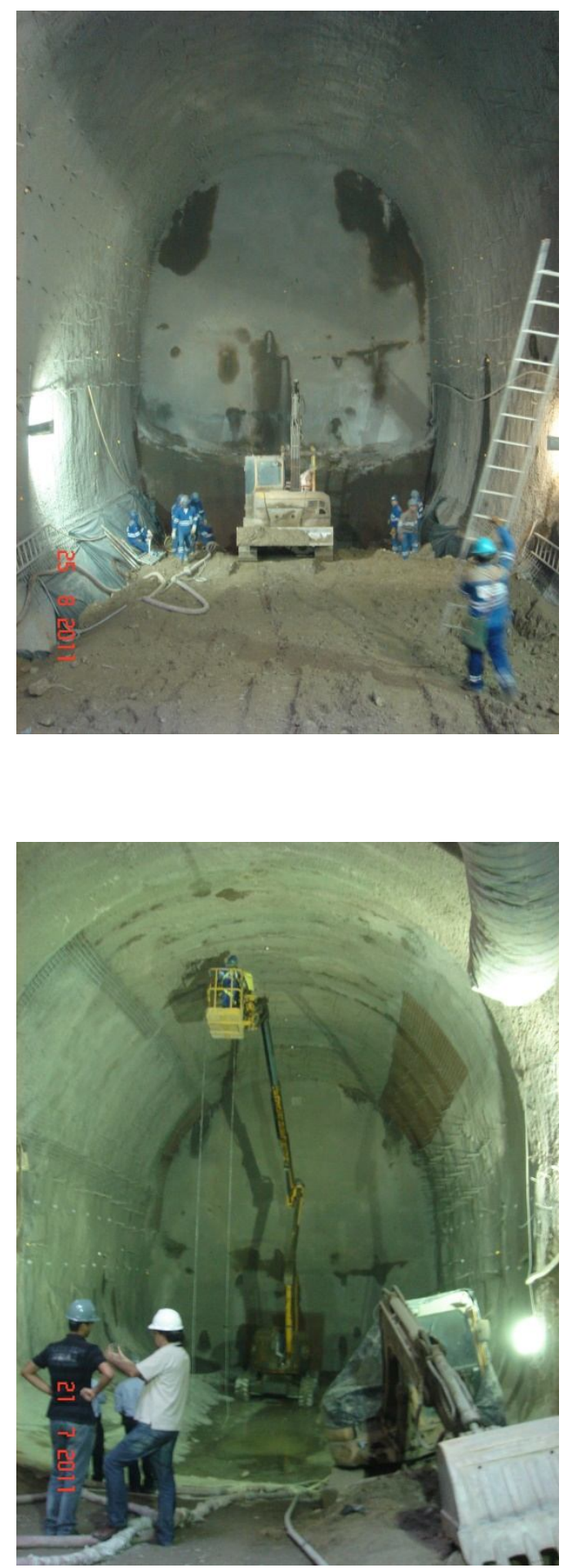
Foto da Escavação do Túnel - Cenário 1

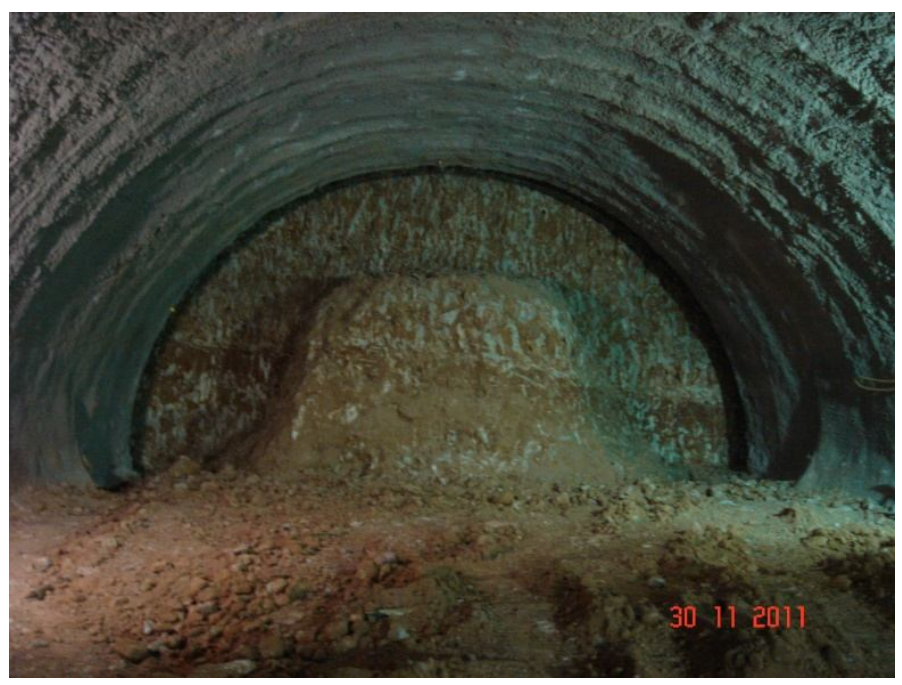

Foto da Escavação do Túnel - Cenário 2

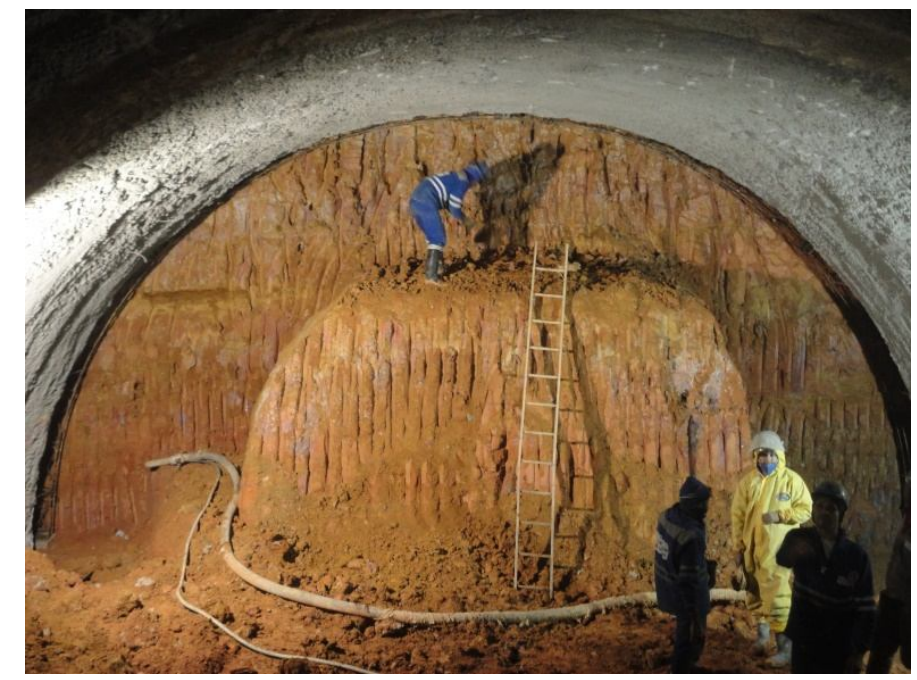


Foto da Escavação do Túnel - Cenário 3

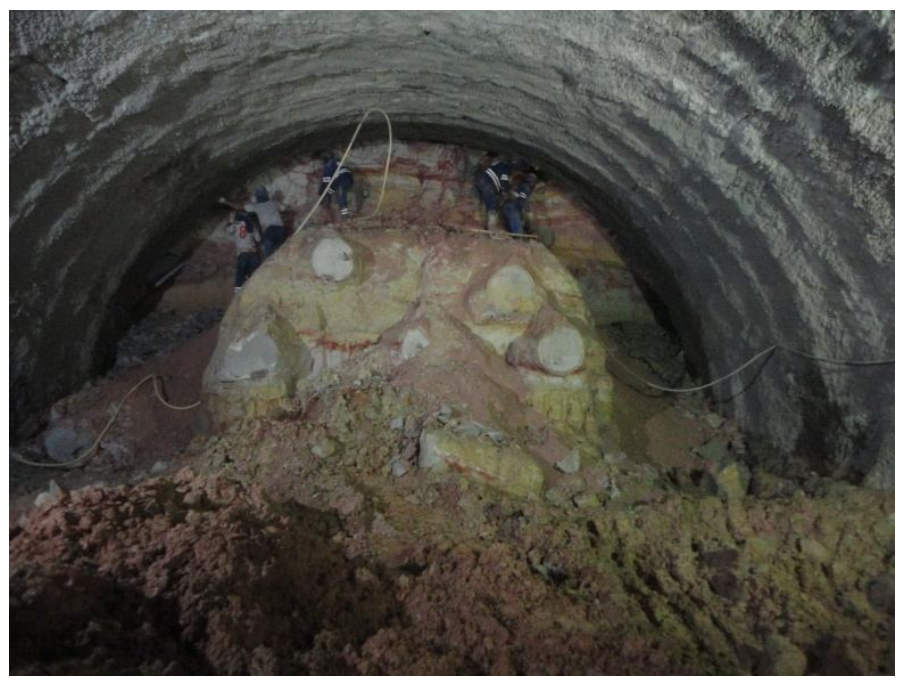

Fotos da Escavação do AIP

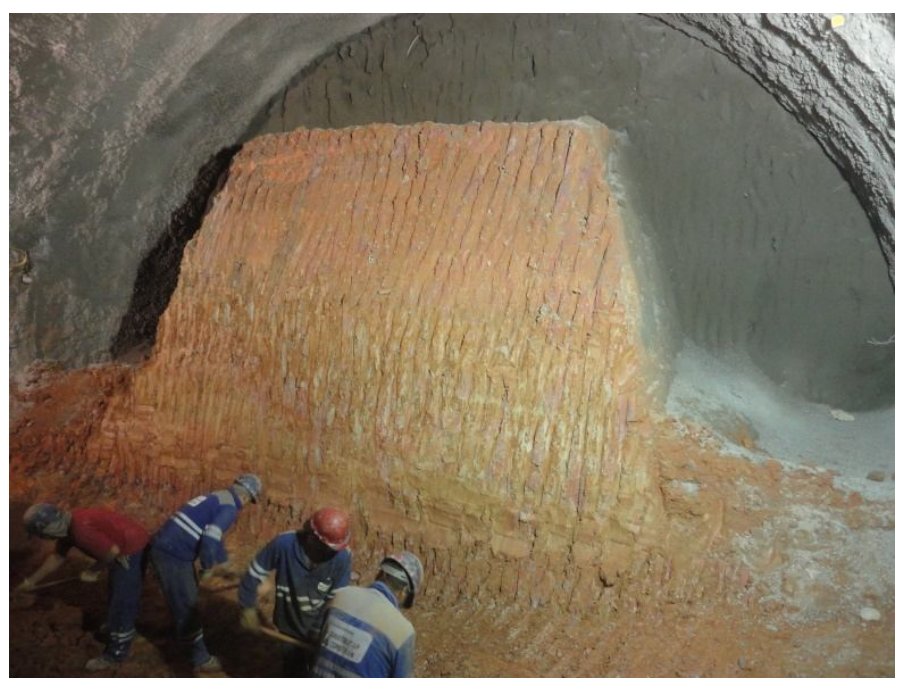




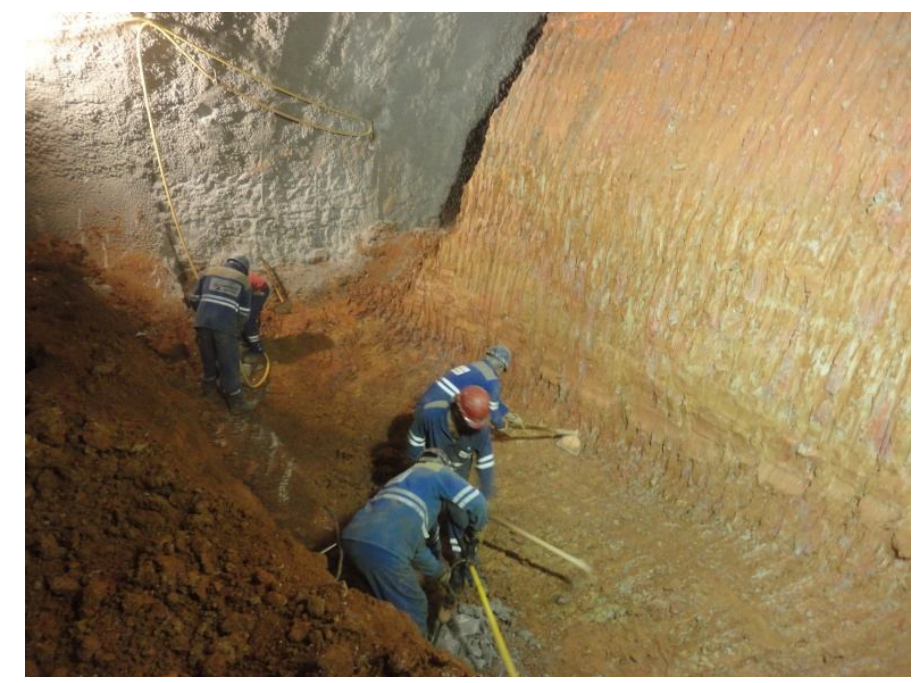

Fotos da Escavação do AID

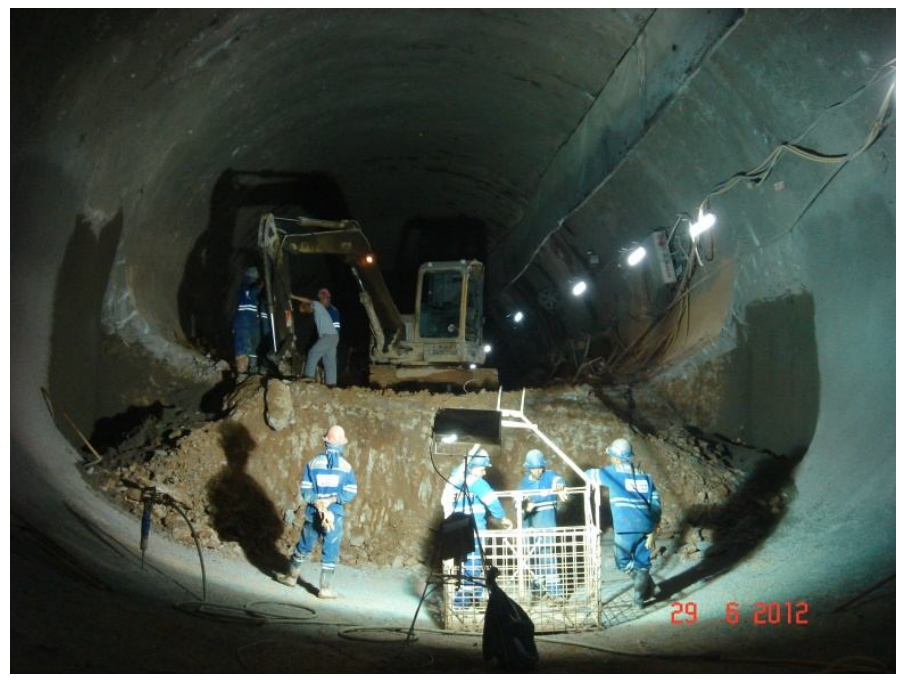



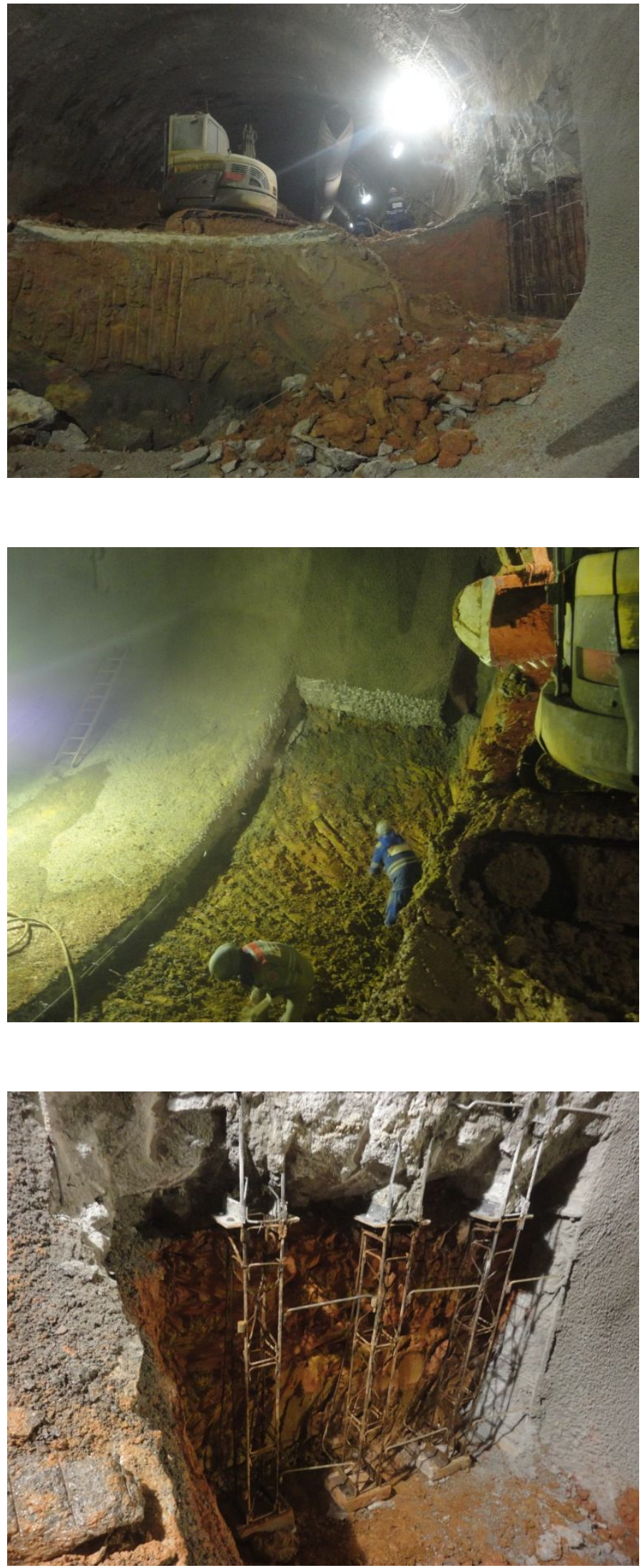
Fotos da Cerimônia de Encontro das Frentes de Escavação
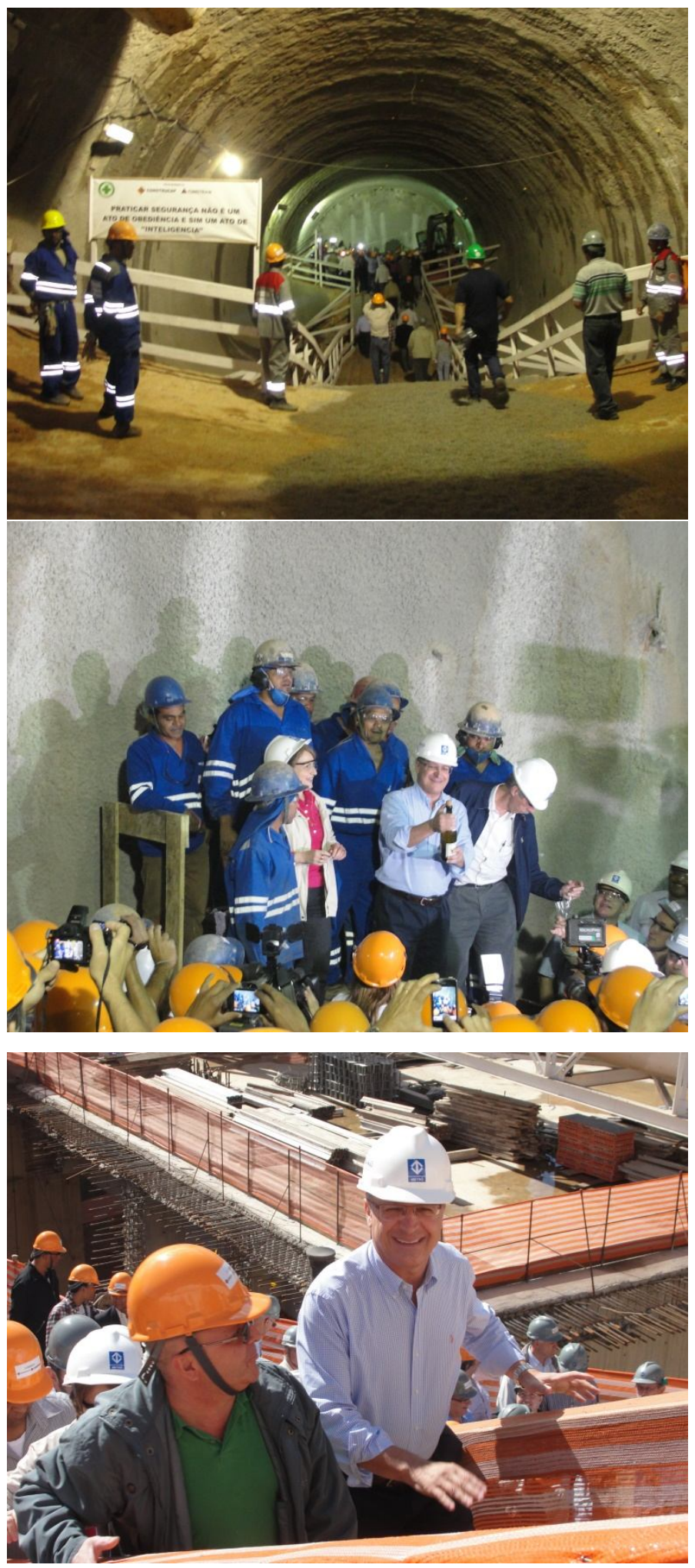